\title{
WestVirginiaUniversity
}

THE RESEARCH REPOSITORY @ WVU

Graduate Theses, Dissertations, and Problem Reports

2003

\section{Real-time measurement of oxides of nitrogen from heavy-duty diesel engines}

Aparna Aravelli

West Virginia University

Follow this and additional works at: https://researchrepository.wvu.edu/etd

\section{Recommended Citation}

Aravelli, Aparna, "Real-time measurement of oxides of nitrogen from heavy-duty diesel engines" (2003). Graduate Theses, Dissertations, and Problem Reports. 1364.

https://researchrepository.wvu.edu/etd/1364

This Thesis is protected by copyright and/or related rights. It has been brought to you by the The Research Repository @ WVU with permission from the rights-holder(s). You are free to use this Thesis in any way that is permitted by the copyright and related rights legislation that applies to your use. For other uses you must obtain permission from the rights-holder(s) directly, unless additional rights are indicated by a Creative Commons license in the record and/ or on the work itself. This Thesis has been accepted for inclusion in WVU Graduate Theses, Dissertations, and Problem Reports collection by an authorized administrator of The Research Repository @ WVU. For more information, please contact researchrepository@mail.wvu.edu. 
Real-time Measurement of Oxides of Nitrogen from HeavyDuty Diesel Engines

Aparna Aravelli

A Thesis

Submitted to:

The College of Engineering and Mineral Resources at West Virginia University

In partial fulfillment of the requirements

for the degree of

Masters of Science

In

Mechanical Engineering

Nigel N. Clark, Ph.D., Chair

Gregory J. Thompson, Ph.D.

W. Scott Wayne, Ph.D.

Department of Mechanical and Aerospace Engineering

West Virginia University

2003

Keywords: Diesel Emissions, Diesel Engines, Modeling 


\section{Abstract \\ Real-time Measurement of Oxides of Nitrogen from Heavy- Duty Diesel Engines}

New emissions regulations and performance requirements imposed on modern diesel engines encourage the development of improved tools for emissions measurements. This study investigated one of the improved tools for $\mathrm{NO}_{\mathrm{x}}$ emissions measurement. Objectives of this thesis included measurement, comparison and prediction of $\mathrm{NO}_{\mathrm{x}}$ emissions from heavy-duty diesel engines using two different $\mathrm{NO}_{\mathrm{x}}$ analyzers. Steady state and transient tests were conducted on six heavy-duty diesel engines in the WVU Engine and Emissions Research Center (EERC). $\mathrm{NO}_{\mathrm{x}}$ emissions were measured using a conventional Rosemount $\mathrm{NO}_{\mathrm{x}}$ analyzer and a Cambustion fast response $\mathrm{NO}_{\mathrm{x}}$ analyzer. The Rosemount analyzer sampled dilute emissions whereas the fast $\mathrm{NO}_{\mathrm{x}}$ analyzer was capable of sampling both raw and dilute $\mathrm{NO}_{\mathrm{x}}$ emissions. Test data obtained from both the analyzers were compared and contrasted. It was observed that there occurred a time shift and dispersion in the measured $\mathrm{NO}_{\mathrm{x}}$ emissions due to the delay and diffusion effects of the sampling train and the difference in response time of each of the analyzers. A difference of about 8-10\% was observed between the measured values of $\mathrm{NO}_{\mathrm{x}}$ emissions from the two analyzers. Instantaneous emissions data obtained from the fast $\mathrm{NO}_{\mathrm{x}}$ analyzer were used to create emissions inventory tables for further analysis. These data were used to deduce power-based fast $\mathrm{NO}_{\mathrm{x}}$ emissions prediction models, which could predict instantaneous $\mathrm{NO}_{\mathrm{x}}$ emissions for different engines and cycles within an error range of 5-13\%. An attempt was also made to derive algebraic backward transformation equations for predicting the instantaneous engine out emissions (raw) from the dispersed (dilute) emissions. 


\section{Table of Contents}

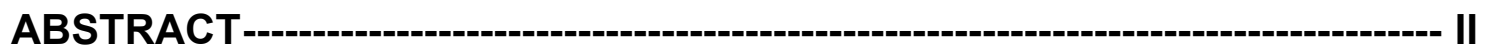

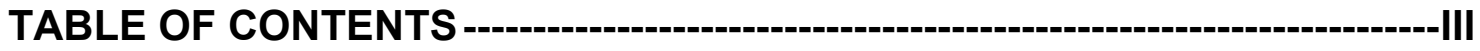

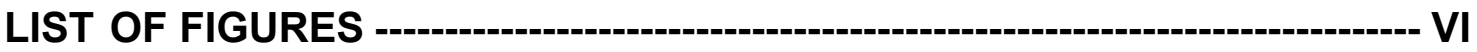

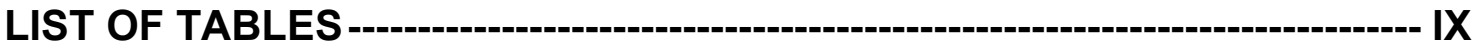

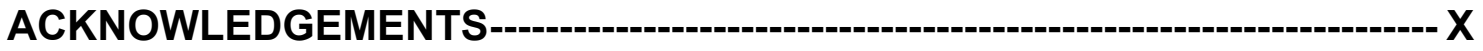

CHAPTER 1 INTRODUCTION, OVERVIEW AND OBJECTIVES---:--:----- 1

1.1 Introduction--- 1

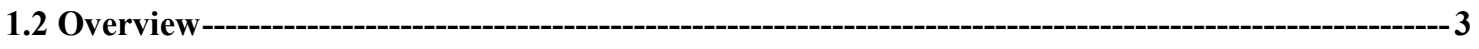

1.3 Objectives---

CHAPTER 2 LITERATURE REVIEW --_- 5

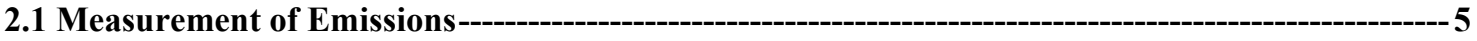

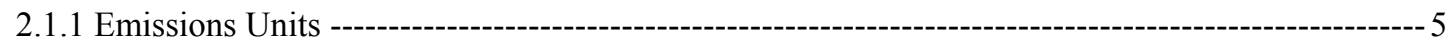

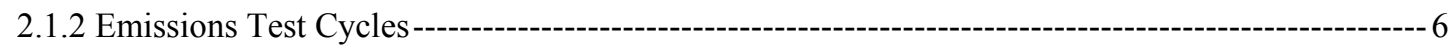

2.1.3 Emissions Measurement Analyzers------o- 6

2.1.3.1Non-Dispersive Infra-Red Detector ------------------------------------------------ 7

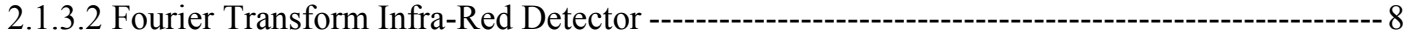

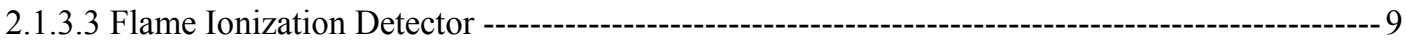

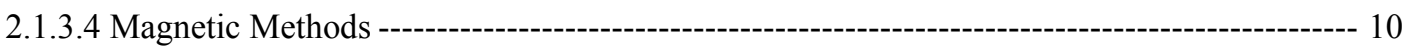

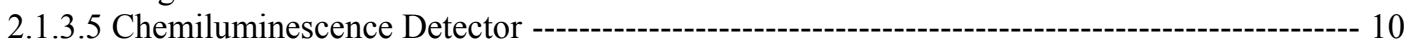

2.2 Analysis of Exhaust Pollutants --on 11

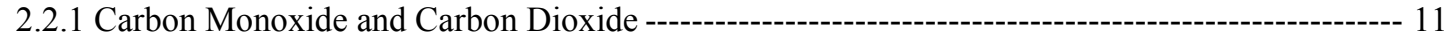

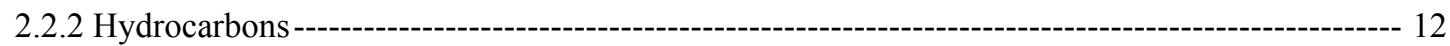

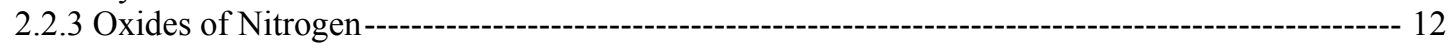

2.3 Slow and Fast Response Analyzers - 13

2.3.1 Slow Response Analyzers----- 13

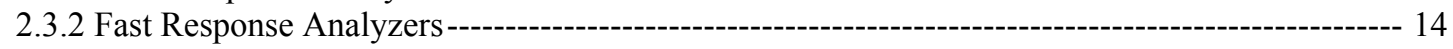

2.4 Theory of Delay and Diffusion ---_- 15

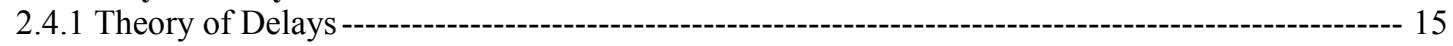

2.4.2 Cross-correlation for Time Delay Calculation ---o- 16

2.4.3 Dispersion Model -----o- 17 
3.2Description of EERC

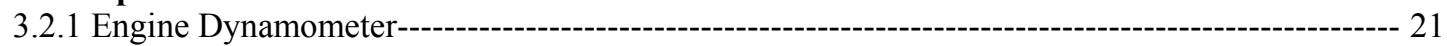

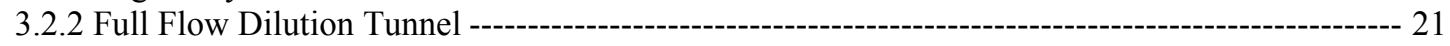

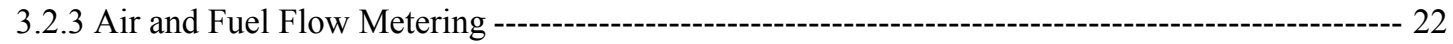

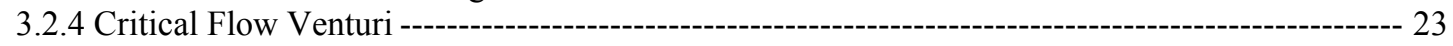

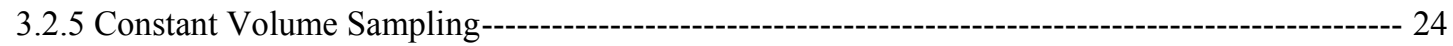

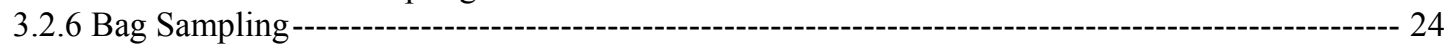

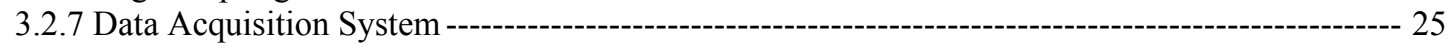

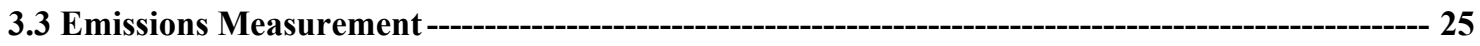

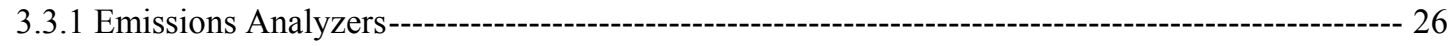

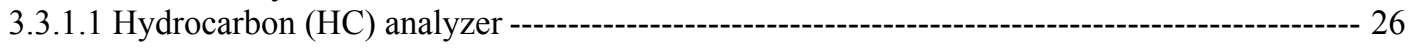

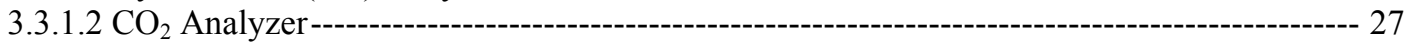

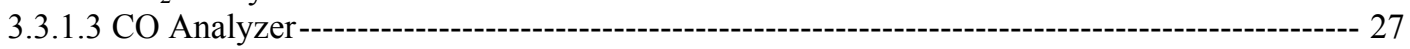

3.3.1.4 PM Sampling --------- 27

3.3.2 NOx Analyzers ------------o- 28

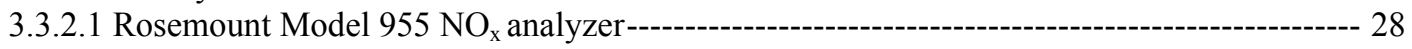

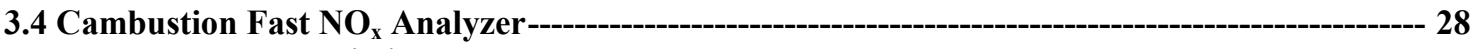

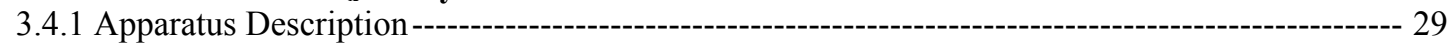

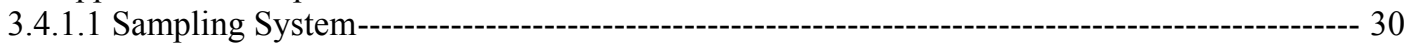

3.4.1.2 Main Control Unit ------------------------------------------------------------- 31

3.4.1.3 Dynamic Calibration System (DCS) --- 31

3.4.1.4 Line Heater Controller (LHC)-- 32

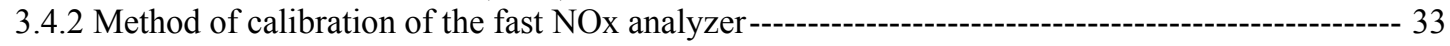

\section{CHAPTER 4 TEST ENGINES SPECIFICATION TEST CYCLES AND TEST}

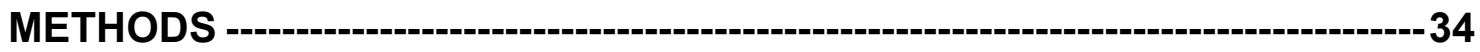

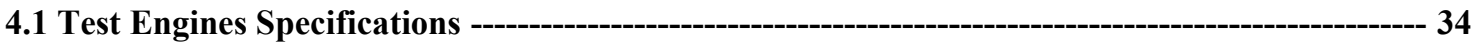

4.1.1 Detroit Diesel Corporation (DDC) Series 60, 2000 Model year --------------------------------- 34

4.1.2 Mack Truck Engine, 1995 Model Year --------------------------------------------------------- 36

4.1.3 Caterpillar Engine, 1996 Model Year ------o- 37

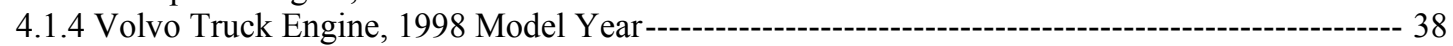

4.1.5 Detroit Diesel Corporation (DDC) Series 60, 1995 Model Year--------------------------------- 39

4.1.6 Navistar Truck Engine, 1999 Model Year --_- 40

4.2 Test Cycles --------on 41

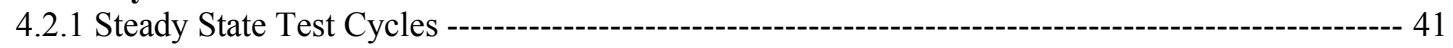

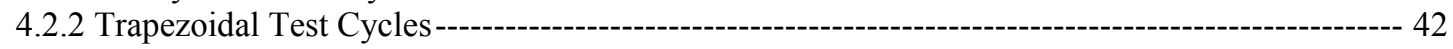

4.2.3 Transient Test Cycles-----o- 45

4.2.3.1 Federal Transient Procedure (FTP) cycle: -----o- 46

4.2.3.2 City-Suburban Heavy Vehicle Route (CSHVR - E): --------

4.2.3.3 European Transient Cycle (ETC - E): ----------------------------------------------- 48

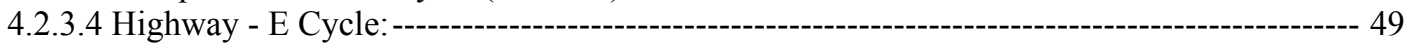

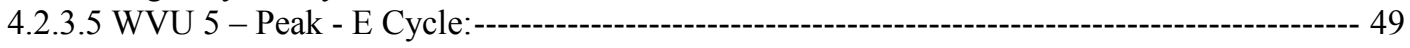

4.3 Test Procedure--- 50

4.4 Instantaneous $\mathrm{NO}_{\mathrm{x}}$ Emissions Calculations - 
5.1 Tests on DDC Series 60, Model Year 2000 -

5.1.1 Steady State Test Results--- 53

5.1.2 Trapezoidal test results ---o--o- 54

5.1.2.1 10-Second Period Oscillation ----- 54

5.1.2.2 4-Second Period Oscillation ----------- 58

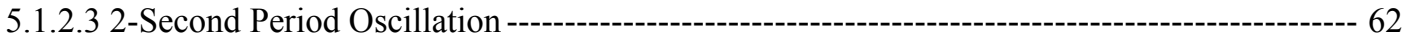

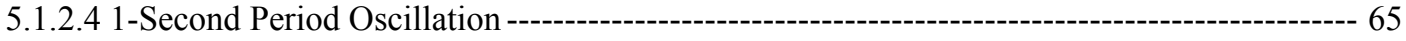

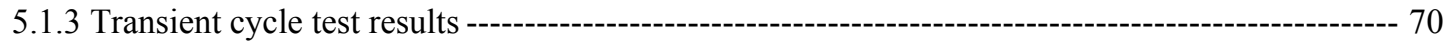

5.1.3.1 Federal Transient Procedure (FTP) --- 70

5.2 Tests on DDC Series 60 Engine, Model Year 1995

5.3 Tests on Caterpillar Engine, Model Year 1996 - 79

5.4 Tests on Volvo Engine, Model Year 1998 - 82

5.5 Tests on Mack Engine, Model Year 1995 --o--on

5.6 Tests on Navistar Engine, Model Year 1999-- 87

5.7 Inventory Tables for Instantaneous $\mathrm{NO}_{\mathrm{x}}$ Emissions - 91

5.8 Instantaneous $\mathrm{NO}_{\mathrm{x}}$ prediction models --- 92

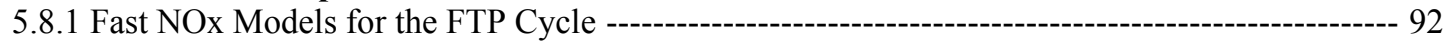

5.8.2 Power based fast NOx models for different transient cycles --

\section{CHAPTER 6 BACKWARD TRANSFORMATION TECHNIQUES FOR NOx} EMISSIONS PREDICTION --:-:-:-ar

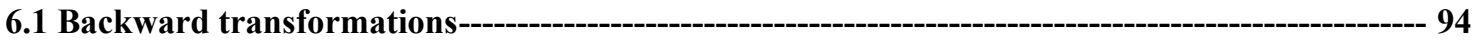

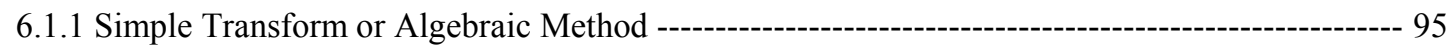

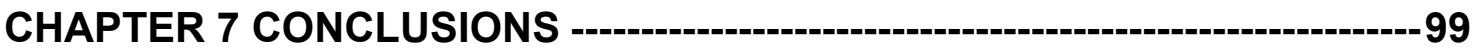

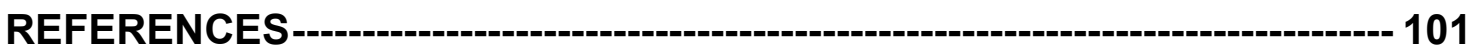

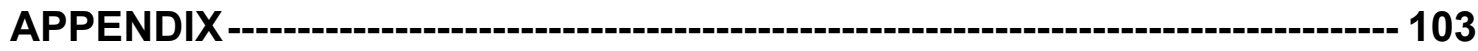




\section{List of Figures}

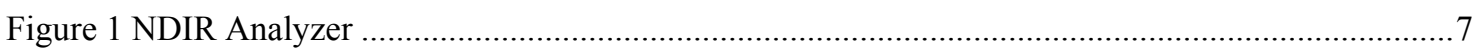

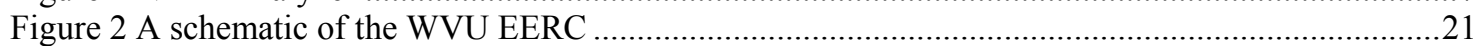

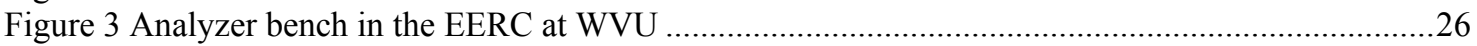

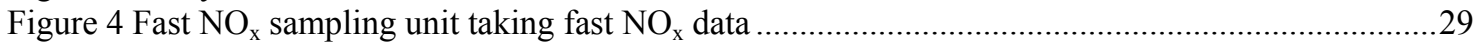

Figure 5 Fast $\mathrm{NO}_{\mathrm{x}}$ analyzer's remote sampling head mounted into exhaust pipe of the DDC Series 60

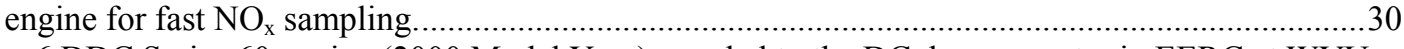

Figure 6 DDC Series 60 engine (2000 Model Year) coupled to the DC dynamometer in EERC at WVU.

Figure 7 Engine map of the DDC Series 60 (2000 Model Year) engine. .................................................36

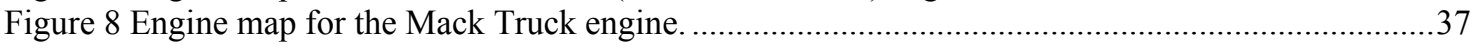

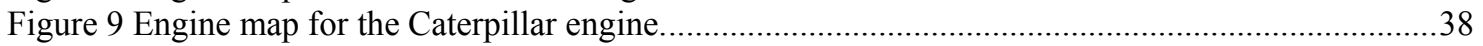

Figure 10 Engine map for the Volvo Truck engine. ...............................................................................

Figure 11 Engine map for the DDC Series 60 (Model Year 1995) engine...............................................40

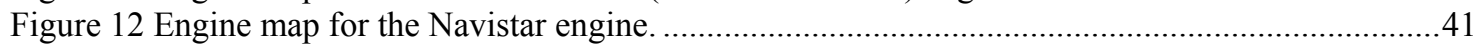

Figure 13 Speed - time trace of a steady-state test cycle run on the DDC Series 60 (Model Year 2000)

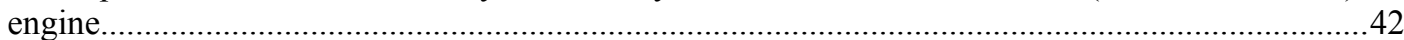

Figure 14 Variation of torque and engine speed with time for the 10-second period trapezoidal wave

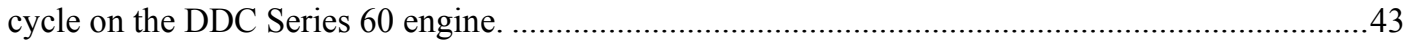

Figure 15 Torque and engine speed plotted with time for the 4-second period trapezoidal wave cycle for

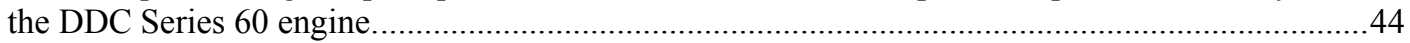

Figure 16 Torque and engine speed plotted against time for the 2-second period trapezoidal wave cycle for the DDC Series 60 engine.

Figure 17 Torque and engine speed plotted against time for the 1-second period trapezoidal wave cycle

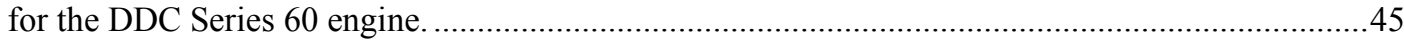

Figure 18 Speed-time trace of a FTP cycle run on the DDC Series 60 engine .......................................46

Figure 19 Speed-time trace of a CSHVR - E conducted on the DDC Series 60 engine...............................47

Figure 20 Speed-time trace of a ETC run on the DDC Series 60 engine................................................48

Figure 21 Speed-time trace of the Highway - E cycle operated on the DDC Series 60 engine. ...............49

Figure 22 Speed-time trace of the WVU 5 - Peak cycle operated on the DDC Series 60 engine. ............50

Figure 23 Variation of $\mathrm{NO}_{\mathrm{x}}$ emissions with time for a steady state test cycle run on the DDC Series 60 engine.

Figure 24 Variation of $\mathrm{NO}_{\mathrm{x}}$ emissions from the two analyzers for the trapezoidal wave with 10 -second

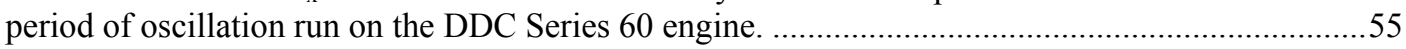

Figure 25 Time shifted slow $\mathrm{NO}_{\mathrm{x}}$ and fast $\mathrm{NO}_{\mathrm{x}}$ plotted against time for the trapezoidal wave with 10second period of oscillation on the DDC Series 60 engine...

Figure 26 Power and $\mathrm{NO}_{\mathrm{x}}$ emissions plotted against time for the trapezoidal wave with 10 -second period

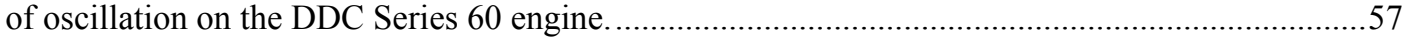

Figure 27 Slow $\mathrm{NO}_{\mathrm{x}}$ plotted against power for the 10 -second trapezoidal wave.......................................58

Figure 28 Fast $\mathrm{NO}_{\mathrm{x}}$ plotted against power for the 10 -second trapezoidal wave. .........................................58

Figure 29 Variation of $\mathrm{NO}_{\mathrm{x}}$ emissions with time for the trapezoidal wave with 4-seconds period of oscillations.

Figure 30 Variation of $\mathrm{NO}_{\mathrm{x}}$ emissions from the two analyzers with a time shift of 10 seconds for slow NOx for the case of the trapezoidal wave with a 4-second period of oscillation................................60

Figure 31 Power and $\mathrm{NO}_{\mathrm{x}}$ emissions variation with time for the trapezoidal wave with 4-second period of oscillations.

Figure 32 Relation between slow $\mathrm{NO}_{\mathrm{x}}$ and power for the trapezoidal wave cycle with 4-second period of oscillations.

Figure 33 Relation between fast $\mathrm{NO}_{\mathrm{x}}$ and power for the trapezoidal wave with 4-second period of oscillations.

Figure 34 Variation of $\mathrm{NO}_{\mathrm{x}}$ emissions with time for a part of the trapezoidal wave cycle with a 2-second period of oscillation.

Figure 35 Variation of $\mathrm{NO}_{\mathrm{x}}$ emissions with time for the trapezoidal wave with 2-second period of oscillations and with slow $\mathrm{NO}_{\mathrm{x}}$ shifted for the time delay. 
Figure 36 Power and $\mathrm{NO}_{\mathrm{x}}$ emission variation with time for a part of the trapezoidal wave with a 2-second period of oscillations.

Figure 37 Relation between power and slow $\mathrm{NO}_{\mathrm{x}}$ emissions for the trapezoidal wave cycle with a 2second period of oscillations.

Figure 38 Relation between power and fast $\mathrm{NO}_{\mathrm{x}}$ emissions for the trapezoidal wave with 2-second period of oscillations.

Figure 39 Slow and fast $\mathrm{NO}_{\mathrm{x}}$ emissions plotted against time for the trapezoidal wave with 1- second period of oscillations with time shifted slow $\mathrm{NO}_{x}$.

Figure 40 Variation of power, slow $\mathrm{NO}_{\mathrm{x}}$ and fast $\mathrm{NO}_{\mathrm{x}}$ with time for the trapezoidal wave with 1-second period of oscillations.

Figure 41 Relation between power and time shifted slow $\mathrm{NO}_{\mathrm{x}}$ for the case of the trapezoidal wave with 1seond period of oscillations.

Figure 42 Relation between fast $\mathrm{NO}_{\mathrm{x}}$ and power for the trapezoidal wave with 1-second period of oscillations.

Figure 43 Variation of amplitude with frequency for the trapezoidal tests.................................................68

Figure 44 Variation of $\mathrm{R}^{2}$ of power fit with frequency for trapezoidal waves......................................70

Figure 45 Variation of $\mathrm{NO}_{\mathrm{x}}$ emissions with time for a FTP cycle operated on the DDC Series 60 engine

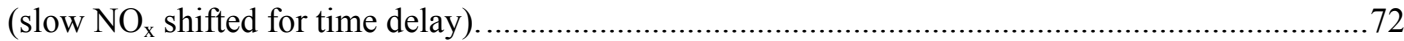

Figure 46 Variation of $\mathrm{NO}_{\mathrm{x}}$ emissions with time for a FTP cycle run on the DDC Series 60 engine. ......72

Figure 47 Variation of $\mathrm{NO}_{\mathrm{x}}$ emissions and power with time for the FTP cycle. .....................................73

Figure 48 Relation between slow $\mathrm{NO}_{\mathrm{x}}$ (without any time shift) and power for the FTP cycle..................73

Figure 49 Relation between slow $\mathrm{NO}_{\mathrm{x}}$ (with time shift) and power for the FTP cycle .............................74

Figure 50 Relation between fast $\mathrm{NO}_{\mathrm{x}}$ and power for the FTP cycle....................................................74

Figure 51 Variation of $\mathrm{NO}_{x}$ emissions with power for a FTP cycle operated on the DDC Series 60 engine.

Figure 52 Variation of $\mathrm{NO}_{x}$ emissions with time for the FTP cycle (with time shifted slow NO $\mathrm{N}_{x}$ data)

Figure 53 Variation of raw fast $\mathrm{NO}_{\mathrm{x}}$ (calculated using intake air flowrate and exhaust flowrate) with time

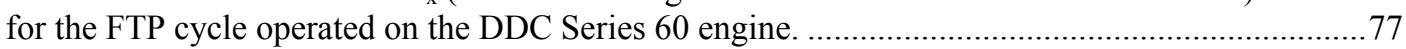

Figure 54 Power and $\mathrm{NO}_{\mathrm{x}}$ emissions with time for the FTP cycle.......................................................78

Figure 55 Relation between power and slow $\mathrm{NO}_{\mathrm{x}}$ emission for the FTP cycle......................................78

Figure 56 Relation between power and fast NOx emissions for the FTP cycle operated on the DDC Series 60 engine.

Figure 57 Variation of slow (dilute) and fast (raw and dilute) $\mathrm{NO}_{\mathrm{x}}$ emissions with time for a FTP cycle

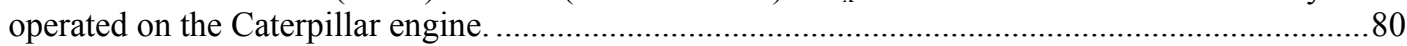

Figure 58 Variation of fast and slow $\mathrm{NO}_{\mathrm{x}}$ emissions with time for a FTP cycle operated on the Caterpillar engine.

Figure 59 Power and $\mathrm{NO}_{\mathrm{x}}$ emissions with time for the FTP cycle. ................................................... 81

Figure 60 Variation of $\mathrm{NO}_{\mathrm{x}}$ emissions with time for the FTP cycle (slow $\mathrm{NO}_{\mathrm{x}}$ shifted for time) run on the

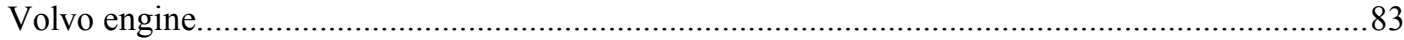

Figure 61 Relation between slow $\mathrm{NO}_{\mathrm{x}}$ and power for the FTP cycle on the Volvo...................................83

Figure 62 Relation between fast $\mathrm{NO}_{\mathrm{x}}$ and power for the FTP cycle on the Volvo................................83

Figure 63 Variation of slow (dilute) and fast (raw and dilute) $\mathrm{NO}_{\mathrm{x}}$ emissions with time for a FTP cycle operated on the Mack truck engine.

Figure 64 Variation of time shifted slow $\mathrm{NO}_{\mathrm{x}}$ and dilute fast $\mathrm{NO}_{\mathrm{x}}$ for the FTP cycle.............................85

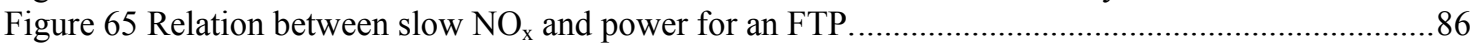

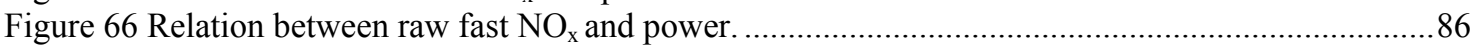

Figure 67 Relation between dilute fast $\mathrm{NO}_{\mathrm{x}}$ and power for a FTP run on the Mack engine......................87

Figure 68 Variation of fast $\mathrm{NO}_{\mathrm{x}}$ (raw and dilute) and slow $\mathrm{NO}_{\mathrm{x}}$ (dilute) with time for a FTP cycle

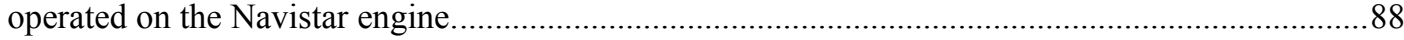

Figure 69 Variation of slow $\mathrm{NO}_{\mathrm{x}}$ data with power for the FTP cycle run on the Navistar engine.............89

Figure 70 Relation between fast $\mathrm{NO}_{\mathrm{x}}$ and power for the FTP cycle run on the Navistar engine...............89

Figure $71 \mathrm{NO}_{\mathrm{x}}$ emissions variation with time for the FTP cycle operated on the Navistar engine............90

Figure 72 Fast $\mathrm{NO}_{\mathrm{x}}$ smoothed using Equation 13, back transformed fast $\mathrm{NO}_{\mathrm{x}}$ using Equation 16, slow

$\mathrm{NO}_{\mathrm{x}}$ with time for the FTP cycle operated on the DDC Series 60 engine. ......................................97

Figure 73 A part of the FTP cycle run on the DDC Series 60 considered for analysis.............................97

Figure $74 \mathrm{Fast}_{\mathrm{NO}}$ data sampled raw plotted against smoothed fast $\mathrm{NO}_{\mathrm{x}}$ data using Equation 13.........98 
Figure 75 Variation of slow and fast $\mathrm{NO}_{\mathrm{x}}$ emissions with time for the ETC $-\mathrm{E}$ cycle run on the DDC

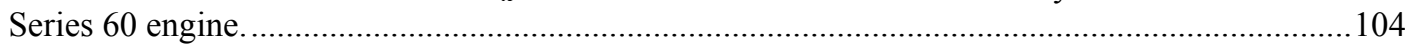

Figure 76 Variation of slow and fast $\mathrm{NO}_{\mathrm{x}}$ emissions with time for the ETC - E with slow $\mathrm{NO}_{\mathrm{x}}$ accounted for time delay

Figure 77 Variation of power and $\mathrm{NO}_{\mathrm{x}}$ emissions with time for the ETC - E cycle. ............................105

Figure 78 Relation between slow $\mathrm{NO}_{\mathrm{x}}$ and power for the ETC - E cycle. ...........................................105

Figure 79 Relation between fast $\mathrm{NO}_{\mathrm{x}}$ and power for the ETC $-\mathrm{E}$ cycle run on the DDC Series 60 engine.

Figure 80 Variation of NOx emissions with time for the CSHVR - E cycle operated on the DDC Series 60 engine.

Figure 81 Variation of $\mathrm{NO}_{\mathrm{x}}$ emissions with time for the CSHVR - E cycle (slow $\mathrm{NO}_{\mathrm{x}}$ shifted for the time

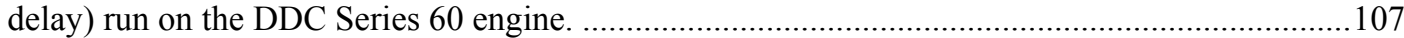

Figure 82 Variation of $\mathrm{NO}_{\mathrm{x}}$ emissions and power with time for the CSHVR - E cycle..........................108

Figure 83 Relation between slow $\mathrm{NO}_{\mathrm{x}}$ and power for the CSHVR - E cycle........................................108

Figure 84 Relation between fast $\mathrm{NO}_{\mathrm{x}}$ and power for the CSHVR - E cycle run on the DDC Series 60 engine.

Highway - E Cycle:

Figure 85 Variation of $\mathrm{NO}_{\mathrm{x}}$ emissions with power for the Highway - E cycle operated on the DDC Series 60 engine.

Figure 86 Variation of $\mathrm{NO}_{\mathrm{x}}$ emissions with time for the Highway - E cycle with slow $\mathrm{NO}_{\mathrm{x}}$ data shifted for the time delay

Figure 87 Power, slow $\mathrm{NO}_{\mathrm{x}}$ and fast $\mathrm{NO}_{\mathrm{x}}$ variation with time for the Highway - E cycle......................111

Figure 88 Relation between slow $\mathrm{NO}_{\mathrm{x}}$ and power for the Highway - E cycle.

Figure 89 Relation between fast $\mathrm{NO}_{\mathrm{x}}$ and power for the Highway - E cycle run on the DDC Series 60 engine.

Figure 90 Variation of $\mathrm{NO}_{\mathrm{x}}$ emissions with time for the WVU 5 - Peak cycle operated on the DDC Series 60 engine. .113

Figure 91 Variation of $\mathrm{NO}_{\mathrm{x}}$ emissions with time for WVU 5- Peak cycle with time shifted slow $\mathrm{NO}_{\mathrm{x}}$ data.

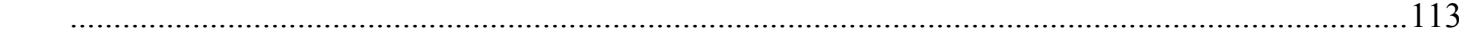

Figure 92 Power and $\mathrm{NO}_{\mathrm{x}}$ emissions variation with time for the WVU 5 - Peak cycle.........................114

Figure 93 Relation between slow $\mathrm{NO}_{\mathrm{x}}$ and power for WVU 5 - Peak cycle.........................................114

Figure 94 Relation fast $\mathrm{NO}_{\mathrm{x}}$ and power for WVU 5 - Peak cycle. 


\section{List of Tables}

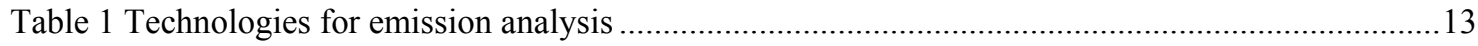

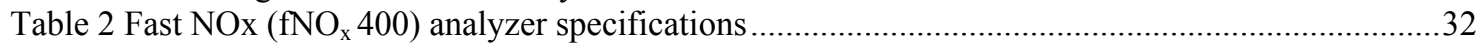

Table 3 Calibration gases used for the FTP cycle for the six heavy-duty diesel engines ..........................33

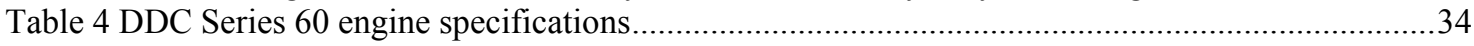

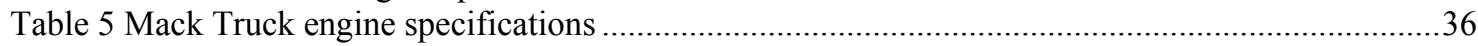

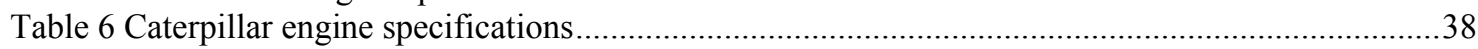

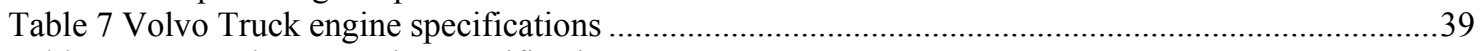

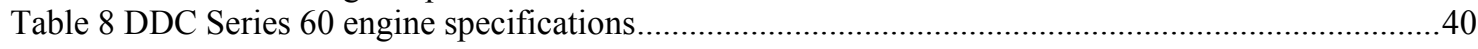

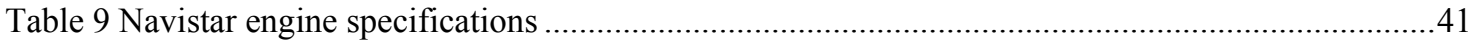

Table 10 Transient engine cycle test measurements from slow and fast $\mathrm{NO}_{\mathrm{x}}$ analyzers. .........................75

Table 11 Fast $\mathrm{NO}_{\mathrm{x}}$ inventory table for the FTP cycle on the Mack engine .............................................91

Table 12 Fast $\mathrm{NO}_{\mathrm{x}}$ inventory table for the FTP cycle on the Caterpillar engine......................................91

Table 13 Fast $\mathrm{NO}_{\mathrm{x}}$ inventory table for the FTP cycle on the DDC Series 60 (1995) engine....................91

Table 14 Fast $\mathrm{NO}_{\mathrm{x}}$ inventory table for the FTP cycle on the Volvo engine .............................................92

Table 15 Fast $\mathrm{NO}_{\mathrm{x}}$ inventory table for the FTP cycle on the Navistar engine ........................................99

Table 16 Fast $\mathrm{NO}_{\mathrm{x}}$ inventory table for the FTP cycle on the DDC Series 60 (2000) engine.....................92

Table 17 Instantaneous NOx emissions prediction for the FTP cycle ....................................................93

Table 18 Instantaneous NOx emissions prediction for transient engine cycles .......................................93 


\section{Acknowledgements}

I express my sincere gratitude to my advisor Dr. Nigel Clark for his valuable guidance and support in earning me a higher degree in my career. I consider it a great opportunity to have worked with him and thank him for preparing me for a better future.

I would like to thank Dr. Gregory Thompson and Dr. Scott Wayne for being my committee members and for their suggestions. Thanks are due to all the people in the EERC at WVU who have helped me during the research work. Special thanks are due to Richard Atkinson and Bradley R. Bane without whom this thesis would have been nowhere. I would also like to thank Ron Jarret, Wessley Riddle, Dan Carder and Tom Spencer for their support.

Next I would like to thank all my friends in Morgantown for all that they have done for me during my study at WVU.

Words fail me in expressing my gratitude to God, my parents and my brother. What I am today is just because of them and I hope to live up to their expectations. I dedicate this thesis research and all my future work to them. 


\section{Chapter 1 Introduction, Overview and Objectives}

\subsection{Introduction}

Diesel engines are the most energy efficient power plants among all the internal combustion engines in production today. The high efficiency translates to good fuel economy and low greenhouse gas emissions but the major downsides are high $\mathrm{NO}_{\mathrm{x}}$ (oxides of nitrogen) and PM (particulate matter) emissions. These emissions lead to deterioration of atmospheric quality and human health. $\mathrm{NO}_{\mathrm{x}}$ emissions are a major contributor for photochemical smog, acid rain and low level ozone formation while PM emissions lead to low atmospheric quality and are considered by many to be carcinogenic to humans. Concerns over atmospheric quality and health effects result in increasingly stringent emissions regulations. The 2007-2010 standards for diesel tailpipe emissions, in the US allow for a maximum of 0.2 grams per brake horsepower hour (g/bhp-hr) of $\mathrm{NO}_{\mathrm{x}}$, $0.01 \mathrm{~g} / \mathrm{bhp}-\mathrm{hr}$ of PM and $0.14 \mathrm{~g} / \mathrm{bhp}-\mathrm{hr}$ of non-methane hydrocarbons (NMHC), all while using 15 parts per million (PPM) sulfur content diesel fuel [1]. These standards bring pressure to bear on manufacturers to improve diesel engine emissions.

Various emission control technologies have been introduced to control and reduce the diesel engine emissions. Diesel emission control technologies can broadly be categorized into three groups: engine design and modifications, fuel and additive technologies and exhaust gas aftertreatment. Engine controls using On Board Diagnostics (OBD) and modifications in the fuel injection system result in $\mathrm{NO}_{\mathrm{x}}$ and $\mathrm{PM}$ emissions reduction. This is achieved by controlling injection timing and injection pressures using electronic unit injectors and common rail rate shaping. $\mathrm{NO}_{\mathrm{x}}$ is reduced by pilot injections and regeneration of particulate traps is what is done through post injections. Combustion air intake improvements using variable geometry turbochargers and combustion chamber 
design using re-entrant bowls (for proper swirl) and in-cylinder coatings of ceramic materials reduce $\mathrm{PM}$ and $\mathrm{NO}_{\mathrm{x}}$.

Another approach in this direction is the use of alternative diesel fuels, fuel additives and lubricating oils. Synthetic diesel fuels (Fisher-Tropsch Fuels), biodiesel and di-methyl ether reduce PM due to their low sulfur content and they have a high cetane rating. Fuel additives such as iron, cerium, copper and platinum when added to diesel fuels decrease PM and act as catalysts in the regeneration of particulate traps [35].

Exhaust gas aftertreatment methods, which include Exhaust Gas Recirculation (EGR), Selective Catalytic Reduction (SCR) and Diesel Oxidation Catalysts (DOC) are the most effective and widely used emission control techniques. EGR is an effective $\mathrm{NO}_{\mathrm{x}}$ reduction strategy in which a part of the engine's exhaust is directed into the combustion chamber via the inlet valve. This results in a decrease in the oxygen content and temperature in the combustion chamber, which are the two main parameters for $\mathrm{NO}_{\mathrm{x}}$ control. Diesel Oxidation Catalysts promote chemical oxidation of carbon monoxide (CO), Hydrocarbon (HC), soluble Organic Fraction (SOF) portion of diesel particulate and the sulfur dioxide $\left(\mathrm{SO}_{2}\right)$, if any. Diesel particulate traps are used to reduce PM emissions by trapping them from the exhaust stream followed by subsequent oxidation. These are generally used in combination with EGR to compensate for the rise in PM due to EGR. Regeneration of the traps is carried out using catalytic coating on the trap, an external electric heater or fuel burner or by a fuel born catalyst. SCR is another $\mathrm{NO}_{\mathrm{x}}$ control technology, which uses ammonia in the form of urea to supplement the catalytic reaction, and thus giving $\mathrm{NO}_{\mathrm{x}}$ the extra molecules needed to convert to harmless nitrogen and water. SCR is a better option for retrofitting in heavy-duty diesel engines because of its high sulfur tolerance. The Lean $\mathrm{NO}_{\mathrm{x}}$ catalyst is a flow-through emissions control device with a potential to lower $\mathrm{NO}_{\mathrm{x}}, \mathrm{HC}$ and $\mathrm{CO}$ emissions significantly. It consists of a $\mathrm{NO}_{\mathrm{x}}$ absorbent and a three way conversion catalyst. $\mathrm{NO}_{\mathrm{x}}$ absorbent is an alkali or alkine 
earth carbonate, which chemically reacts with $\mathrm{O}_{2}$ and $\mathrm{NO}_{\mathrm{x}}$ in the exhaust and forms alkali and alkaline earth metal nitrates. $\mathrm{NO}_{\mathrm{x}}$ stored in the adsorbent is released and reduced to $\mathrm{N}_{2}$. Plasma exhaust treatment is another new technology, still in its early stages, which controls $\mathrm{NO}_{\mathrm{x}}$ emissions by the oxidation of $\mathrm{NO}$ to $\mathrm{NO}_{2}$ (nitrogen dioxide). Non-Thermal plasma diesel particulate filters are used with $\mathrm{SCR}$ for $\mathrm{NO}_{\mathrm{x}}$ and $\mathrm{PM}$ reduction [28].

No single technology is a complete solution to meet up the ever-increasing demand for emissions reduction. An ideal case would be the usage of a combination of one or more of these technologies to achieve an optimal reduction in emissions [26].

\subsection{Overview}

The drive in increased use of diesel engines coupled with the need for a more precise $\mathrm{NO}_{\mathrm{x}}$ emissions inventory describing the contribution of heavy-vehicle fleet necessitates research in $\mathrm{NO}_{\mathrm{x}}$ reduction technologies. These two needs can be aided by using advanced engine/vehicle emissions models and more accurate emissions measurement systems. An advanced vehicle emissions model could describe the vehicle emissions rate as a function of vehicle activity. Activity of individual vehicles may be available from advanced traffic simulation models to assist inventory. For engine management the instantaneous $\mathrm{NO}_{\mathrm{x}}$ model might be used in the control of reductant injection.

The standard engine testing and emissions measurement carried out in a test cell, according to the procedure described in CFR 40 part 86 [14], gives the diluted exhaust emissions data but not the true engine exhaust manifold instantaneous emissions. Also it is known that the measured $\mathrm{NO}_{\mathrm{x}}$ emissions do not coincide in time with engine or vehicle load and speed (there occurs a time shift). Previous research [8] had shown that there occurred a delay and diffusion in the analyzer measured emissions due to entire sampling train from the engine's exhaust manifold to the analyzer. Hence there is a need to study the dependence of emissions on the sampling train including the analyzer type and to 
measure the true exhaust manifold instantaneous emissions. This defines the purpose of the present research.

\subsection{Objectives}

The main objectives of this research were:

i) To compare and contrast the $\mathrm{NO}_{\mathrm{x}}$ emissions measured using two different $\mathrm{NO}_{\mathrm{x}}$ analyzers.

ii) To produce instantaneous $\mathrm{NO}_{\mathrm{x}}$ emissions inventory tables.

iii) To develop power-based $\mathrm{NO}_{\mathrm{x}}$ emissions models for different engine test cycles.

iv) To predict the instantaneous $\mathrm{NO}_{\mathrm{x}}$ emissions using Algebraic Backward Transformation Techniques.

$\mathrm{NO}_{\mathrm{x}}$ emissions were measured using a traditional laboratory grade heated chemiluminescent Rosemount $\mathrm{NO}_{\mathrm{x}}$ analyzer and a new Cambustion fast $\mathrm{NO}_{\mathrm{x}}$ analyzer with a faster response than the Rosemount analyzer. The first objective was to compare $\mathrm{NO}_{\mathrm{x}}$ emissions from both the analyzers. The next objective was to analyze the data obtained from the tests performed and use them to develop emissions inventory tables. These inventory tables were then used to study the effect of engine power on $\mathrm{NO}_{\mathrm{x}}$ emissions so as to develop power based $\mathrm{NO}_{\mathrm{x}}$ emissions models based using the fast $\mathrm{NO}_{\mathrm{x}}$ data. The final objective was to derive algebraic equations for the prediction of instantaneous exhaust manifold (raw) $\mathrm{NO}_{\mathrm{x}}$ emissions from the dilute $\mathrm{NO}_{\mathrm{x}}$ emissions measured according to the standard test methods and apply them to the experimental $\mathrm{NO}_{\mathrm{x}}$ data obtained from both the $\mathrm{NO}_{\mathrm{x}}$ analyzers. 


\section{Chapter 2 Literature Review}

\subsection{Measurement of Emissions}

Emissions can be characterized, regulated, or controlled only if they can be accurately measured. The increased health and environmental concerns about diesel emissions resulted in the development of a wide range of measurement techniques of different levels of sophistication, equipment cost and accuracy, to suit a variety of applications. Many techniques, especially those used for regulatory purposes, are highly standardized to produce comparable results even if performed at different testing laboratories. The main types of diesel emission measurements can be grouped as follows:

1. Laboratory testing
a) Regulatory testing
b) Emissions research
c) Engine and emission control system development

2. Field testing
a) Mobile emission laboratories
b) On-vehicle measurements
c) Inspection and maintenance (I \&M) programs
d) Remote emission measurement
e) Emission-assisted equipment maintenance
f) Occupational health measurements

Engine emissions are highly dependent on engine operating conditions, such as speed, load, or transients [3].

\subsubsection{Emissions Units}

Emissions measured on a chassis dynamometer are typically expressed in grams of pollutant per unit of distance e.g., $\mathrm{g} / \mathrm{km}$ or $\mathrm{g} / \mathrm{mi}$. Emissions measured over an engine dynamometer test cycle are expressed in grams of pollutant per unit of mechanical energy delivered by the engine, such as $\mathrm{g} / \mathrm{kWh}$ or $\mathrm{g} / \mathrm{bhp}-\mathrm{hr}$. The mass emission rate of the 
pollutant may also be given in grams per second $(\mathrm{g} / \mathrm{s})$. Emissions based on the fuel consumed are given by g/gal.

\subsubsection{Emissions Test Cycles}

Diesel emission measurements are performed on an engine or vehicle dynamometer, over a standardized emission test cycle. Engine (emission) test cycles are repeated sequences of engine operating conditions, designed to simulate real-life operation in the laboratory.

Depending on the speed and load changes, the emissions test cycles can be classified as steady-state cycles and transient cycles. Steady state test cycles are sequences of constant engine speed and load modes whereas in transient test cycles the vehicle/engine follows a prescribed driving pattern, which includes acceleration, decelerations, and changes of speed and load. For steady state tests, emissions are analyzed for each test mode. Then the overall emission result is calculated as a (weighted) average from all test modes. The results of a transient test are obtained either by analysis of exhaust gas samples collected over the duration of the cycle or by electronic integration of a fast response, continuous emission measurement. Different test cycles used in this research are described in detail in Section 4.2.

\subsubsection{Emissions Measurement Analyzers}

Measurement of exhaust gases is accomplished using exhaust gas analyzers. These analyzers are constructed based on certain physical properties of the measured gases. The gas analysis techniques can broadly be classified as

1. Non-dispersive infrared analysis (NDIR)/Fourier-transform infrared (FTIR) for measuring $\mathrm{CO}, \mathrm{CO}_{2}, \mathrm{NO}, \mathrm{NO}_{2}$ etc.

2. Flame ionization detection (FID) used for measuring hydrocarbons (HC)

3. Chemiluminescence analysis for $\mathrm{NO}_{\mathrm{x}}$ 
In addition to the above-mentioned techniques, electrochemical, zirconia oxide and nondispersive ultra-violet (NDUV) methods are also used.

A brief description of each of the general techniques used for exhaust gas measurement is given below.

\subsubsection{Non-Dispersive Infra-Red Detector}

The NDIR analyzer makes use of the property of certain gases of selectively absorbing infrared radiation over a narrow range of wavelengths. Molecules which are formed of atoms of at least two different elements (CO, $\mathrm{NO}, \mathrm{NO}_{2}, \mathrm{SO}_{2}$, etc.) absorb infrared radiation by converting the light energy into vibration/rotation energy of the molecules, which can be detected in the form of heat. NDIR instruments use the total absorption over a given wavelength range, rather than using a monochromator (prism or grating) to separate the light. The spectral range used is the near and middle infrared (0.75 - 30 micron wavelength) [2].

The basic working principle of a typical NDIR instrument is illustrated in Figure 1. The infrared emitters $(\mathrm{E})$ are heated filaments that act like black body radiators over a wide range of wavelengths. The detection receiver (D) is a volume of gas identical to that to be measured in the analyzed gas mixture. Thus, the receiver remains insensitive to absorption by other chemicals as long as their absorption ranges do not overlap. Most of the instruments use twin beams generated by two identical infrared sources. The incident infrared beams are modulated by a rotating chopper (M).

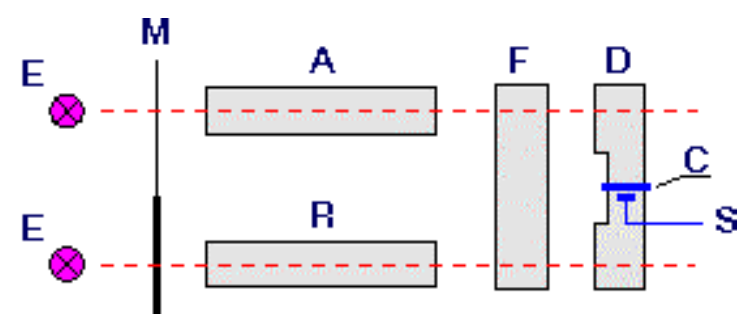

Figure 1 NDIR Analyzer 
One beam passes through an absorption cell (A) containing the analyzed gas. The other beam passes through a reference cell $(\mathrm{R})$ filled with an inert gas, such as nitrogen. After passing through a compensation cell $(\mathrm{F})$ the two beams pass through two chambers filled with the gas to be measured in its pure state which comprise a differential pressure sensor (D). It is a Golay pressure sensor consisting of two identical chambers separated by a diaphragm $(\mathrm{C})$ that moves between plates of a capacitor. The difference in heat received in each chamber due to the presence of the analyzed gas on the path of one of the halfbeams causes increased pressure on one side of the diaphragm. The pressure is modulated by the rotating chopper (M) turning at a frequency of about $10 \mathrm{~Hz}$. The output signal (S) from the cell represents the variations of capacitance of the system. The two detector chambers are connected by a capillary (in some instruments) to compensate for ambient temperature gradients.

NDIR is sensitive to pressure, so this parameter must remain constant during the calibration and analysis. It is also sensitive to water vapor. Materials used in some IR analyzers (alkaline earth halogenide windows) are also sensitive to water. Gas samples for IR analysis are thus dried before entering into the analyzer to remove the water content. NDIR analyzers can be used to measure many gases, including $\mathrm{CO}, \mathrm{CO}_{2}, \mathrm{CH}_{4}$, $\mathrm{NO}, \mathrm{N}_{2} \mathrm{O}, \mathrm{SO}_{2}, \mathrm{HCl}$, and hydrocarbons. They are mainly used for $\mathrm{CO}$ and $\mathrm{CO}_{2}$ in diesel and automotive exhaust analysis [2].

\subsubsection{Fourier Transform Infra-Red Detector}

The FTIR analyzer generates interferograms of two IR beams of changing length optical paths. The beams originate from the same source. One of them is reflected on a fixed mirror and the second on a vibrating mirror. The amplitude of the vibrating mirror induces differences in optical paths. When the beams recombine, interference fringes (interferogram) are created which contain all the information on the spectral distribution 
of the source radiation. When that radiation is sent to the gas mixture, spectral components corresponding to the absorption spectra of the different gases are absorbed. The light intensity distribution is attenuated by the presence of the chemicals. Results are generated by a computer, which runs the mathematical Fourier transform to obtain the intensity distribution as a function of wavelength from the intensity distribution as a function of the optical path. Particular gas concentrations are obtained from the intensity distribution on the basis of their known IR absorption spectra. Concentration distributions of different chemicals may be obtained simultaneously and selectively in the FTIR instrument.

Although the response time of FTIR instruments is rather slow (over 5s) the actual measurement cycle is less than $1 \mathrm{~s}$, thus allowing real-time measurements. The method is particularly useful for analysis of $\mathrm{NO}, \mathrm{NO}_{2}, \mathrm{CO}, \mathrm{CO}_{2}$, short chain alcohols, hydrocarbons and aldehydes (e.g., methanol, ethanol, formaldehyde) as well as several other compounds. FTIR is not suitable for measuring longer chain HCs that are typical for diesel exhaust [2].

\subsubsection{Flame Ionization Detector}

The flame ionization detector (FID) is used for measuring hydrocarbons. It depends on the production of free electrons and positive ions during the combustion of hydrocarbons in a non-ionized hydrogen flame. A current, in the range of $10 \mathrm{pA}$, is generated between the burner and an electrode raised to $100-300 \mathrm{~V}$. The current is a function of the number of carbon atoms that pass through the flame.

"Hydrocarbons" as measured by the FID analyzer include any compounds containing carbon. The results of measurement are reported as ppm by volume of carbon (ppm $\mathrm{C}$ or ppm C1) measured in comparison with an aliphatic hydrocarbon reference, usually propane or hexane. The reference "ppm C1" is just a customary unit corresponding to the 
quantity of carbon atoms in the analyzed gas. The FID response for organic compounds may also deviate from real concentrations, depending on the particular molecule. This is especially true for oxygenated compounds, such as alcohols, aldehydes, ketones, nitrocompounds, or ethers.

The flame in a FID instrument is usually generated by combusting a $40 \% \mathrm{H}_{2}$ / $60 \%$ He mixture in air. Any oxygen present in the exhaust sample due to incomplete combustion, influences the FID analyzer. To minimize this effect, zero and reference gases are used with $\mathrm{O}_{2}$ content close to that of the gas to be measured. FID instruments are unaffected by the water vapor in the analyzed gas [2].

\subsubsection{Magnetic Methods}

Some gases including oxygen and nitrogen oxides exhibit paramagnetic properties. When a paramagnetic gas is subjected to a heterogeneous magnetic field it undergoes a force directed towards increasing fields. This magnetic force can be measured in a number of ways, which is the principle of a paramagnetic gas analyzer. In practice, paramagnetic analyzers are used to measure oxygen concentration in diesel or automotive exhaust gases [2].

\subsubsection{Chemiluminescence Detector}

The chemiluminescence detector (CLD) utilizes a chemical reaction between nitric oxide and ozone:

$$
\mathrm{NO}+\mathrm{O}_{3}=\mathrm{NO}_{2}^{*}+\mathrm{O}_{2}=\mathrm{NO}_{2}+\mathrm{O}_{2}+\text { photon } \quad \text { Equation } 1
$$

Ozone is produced in the instrument by a high-voltage discharge in oxygen. The excited nitrogen dioxide molecules spontaneously return to the normal state. This transition is accompanied by emission of red light with photon emissions in the 0.6 to 3 micron band. The light emission is filtered to eliminate interference from other gases, 
such as $\mathrm{CO}, \mathrm{SO}_{2}$ and unsaturated hydrocarbons, and measured by a photo multiplier. The signal is proportional to the NO concentration in the sample.

The same instrument can also measure total $\mathrm{NO}_{\mathrm{x}}$ which is considered as the total of $\mathrm{NO}$ and $\mathrm{NO}_{2}$. The gas sample passes through a stainless steel or molybdenum catalyst in a convertor where, at elevated temperature, $\mathrm{NO}_{2}$ is decomposed to $\mathrm{NO}$ and oxygen. This $\mathrm{NO}$ is then passed through the analyzer, which gives a measure of the total $\mathrm{NO}_{\mathrm{x}}$ (in terms of $\mathrm{NO}$ ) that is the sum of $\mathrm{NO}$ initially present in the sample and the $\mathrm{NO}_{2}$ in the sample converted to $\mathrm{NO}$. $\mathrm{NO}_{2}$ concentration may be calculated as a difference between the total $\mathrm{NO}_{\mathrm{x}}$ and $\mathrm{NO}$ results.

CLD instruments offer a wide measuring range with a fast response time. Their drawbacks are interferences caused by water vapor and carbon dioxide, as well as the need for complex and expensive equipment, including such additional components as vacuum pumps and deozonizer [4].

\subsection{Analysis of Exhaust Pollutants}

\subsubsection{Carbon Monoxide and Carbon Dioxide}

In most research laboratories $\mathrm{CO}$ and $\mathrm{CO}_{2}$ are measured by the NDIR technique [5]. The accuracy of measurement is essentially governed by the calibration. Samples for analysis are dried (to remove the water content) prior to entering the analyzers.

Heated NDIR analyzers (h-NDIR) are being developed, mainly for on-board measurement applications, which allow for measurement under wet gas conditions [6]. Wet-based NDIR analyzers must correct for the interference from water vapors. Good results in measuring $\mathrm{CO}$ and $\mathrm{CO}_{2}$ are also obtained by the FTIR analyzer. 


\subsubsection{Hydrocarbons}

In most research laboratories the total hydrocarbons (THC) are measured by the FID technique. A heated FID is used, especially for diesel applications, to avoid condensation and loss of heavier hydrocarbons. Non-methane hydrocarbons (NMHC) can be measured by chromatographic separation and subtracting methane from the total hydrocarbons. Formerly, the NDIR analyzers were also used to measure exhaust hydrocarbons. Today this method has been abandoned because of poor results. NDIR instruments yielded different response for different hydrocarbon species [2].

\subsubsection{Oxides of Nitrogen}

Nitrogen oxides, $\mathrm{NO}_{\mathrm{x}}$, are measured using the chemiluminescence method. The laboratory grade chemiluminescence instrument requires cold and dry sample to avoid condensation and dissolving of $\mathrm{NO}_{2}$ in the condensate. Heated versions of chemiluminescence analyzers operate with hot and wet samples. The measured gas in this analysis is $\mathrm{NO}$. A convertor with a catalyst to reduce $\mathrm{NO}_{2}$, which allows measuring total $\mathrm{NO}_{\mathrm{x}}$, is a standard feature on most analyzers. $\mathrm{NO}_{2}$ concentrations can be calculated from the difference of $\mathrm{NO}_{\mathrm{x}}$ and $\mathrm{NO}$.

FTIR spectroscopy yields also very good accuracy for measuring $\mathrm{NO}_{\mathrm{x}}$. It measures $\mathrm{NO}$ and $\mathrm{NO}_{2}$ directly and simultaneously. Total $\mathrm{NO}_{\mathrm{x}}$ can be calculated as a sum of $\mathrm{NO}$ and $\mathrm{NO}_{2}$. Ultra-violet (UV) spectroscopy is still another method capable of measuring $\mathrm{NO}_{\mathrm{x}}$ in vehicle exhaust [4]. In comparison to CLD, UV analyzers may offer less noise, no water and $\mathrm{CO}_{2}$ interference, and simpler and less expensive equipment.

General methods used in the laboratories for the analysis of exhaust gas constituents are listed in Table 1. $\mathrm{CO}$ and $\mathrm{CO}_{2}$ are measured using the NDIR technique and $\mathrm{NO}_{\mathrm{x}}$ is measured using the chemiluminescence and FTIR techniques. $\mathrm{HC}$ is measured using the FID and FTIR techniques. 
Table 1 Technologies for emission analysis

\begin{tabular}{|l|l|l|l|}
\hline \multicolumn{1}{|c|}{ Technique } & \multicolumn{1}{|c|}{ Gas } & \multicolumn{1}{c|}{$\begin{array}{c}\text { Typical } \\
\text { Range }\end{array}$} & $\begin{array}{c}\text { 90\% Response } \\
\text { Time }\end{array}$ \\
\hline \multirow{2}{*}{ Non-dispersive infra-red (NDIR) } & $\mathrm{CO}$ & $0-3000 \mathrm{ppm}$ & $2-5 \mathrm{~s}$ \\
\cline { 2 - 5 } & $\mathrm{CO}_{2}$ & $0-20 \%$ & $2-5 \mathrm{~s}$ \\
\hline $\begin{array}{l}\text { Chemiluminescence (slow and fast } \\
\mathrm{NO}_{\mathrm{x}} \text { ) }\end{array}$ & $\mathrm{NO}_{\mathrm{x}}$ & $0-10,000 \mathrm{ppm}$ & $\begin{array}{l}1.5-2 \mathrm{~s}(\mathrm{slow}) \\
<4 \mathrm{~ms}\end{array}$ \\
\hline Flame ionization detector (FID) & Total HC & $0-10,000 \mathrm{ppm}$ & $1-2 \mathrm{~s}$ \\
\hline Fast FID & Total $\mathrm{HC}$ & $0-2,000 \mathrm{ppm}$ & $1-2 \mathrm{~ms}$ \\
\hline Fourier transform infra-red (FTIR) & NOx, some HC, etc. & various & $5-15 \mathrm{~s}$ \\
\hline Paramagnetic analyzer & $\mathrm{O}_{2}$ & $0-25 \%$ & $1-5 \mathrm{~s}$ \\
\hline
\end{tabular}

\subsection{Slow and Fast Response Analyzers}

Analyzers used for emissions measurement vary depending on the test being carried out according to the procedure described in the Code of Federal Regulations (CFR) 40, Part 86. They have to operate under one of two quite different conditions. During steady state tests the demand is for an accurate measurement of a sample collected or integrated over a fairly long time interval whereas for transient tests instantaneous measurement under rapidly changing conditions is the requirement along with the measurement accuracy. Analyzers are therefore constructed to suit these two conflicting requirements and are called slow response and fast response analyzers.

\subsubsection{Slow Response Analyzers}

Slow response analyzers are mostly for steady-state work and are accurate, sensitive and stable and have slow response time and are well damped. Conventional laboratory grade analyzers designed to measure various emission species mostly give accurate results for steady state tests but are not very suitable for true transient engine testing because of their slow response [2] Slow analyzers are still being used for the standard FTP cycle for 
emissions testing. A better option would be the usage of fast response analyzers for transient testing because of their quick response.

\subsubsection{Fast Response Analyzers}

The main feature that differentiates a fast response analyzer from a slow analyzer is its response time. In general, the response time of an analyzer can be defined as the time gap between the sample entering into the system and the system giving an output signal. This response time is a combination of response due to the sample flow into the system and the response due to the electronic circuitry. The electronic response time is defined as the time taken for reaching $10-90 \%$ of the output for a step change in input. Most fast response analyzers have a $10-90 \%$ of the electronic response time of a few milliseconds making them suitable for resolving transient engine phenomena at high engine speeds. This fast response feature is obtained by placing the sample head very near to the sampling point and by decreasing the sample inlet volume, increasing the sample flow rate and reducing the sample residence time inside the system so that a little amount of sample enters the system and exits quickly.

In order to measure the continuous real time levels of the emission species in transient tests, fast response analyzers are used [10]. They also yield information on transient engine calibration, gear change misfires, and driveability and burn quality. Researchers and calibrators use fast response analyzers to study cold start emissions [11], to investigate and optimize direct injection system in gasoline direct injection engines (GDI) [12], accurately control exhaust gas recirculation (EGR) [13], develop $\mathrm{NO}_{\mathrm{x}}$ traps and measure residual gas fraction. Fast response analyzers have previously been used for many applications, which include transient fuelling calibration, $\mathrm{NO}_{\mathrm{x}}$ trap purging, and cold start analysis. 


\subsection{Theory of Delay and Diffusion}

Engine testing and emissions measurement systems usually provide the emissions for a whole test cycle as cycle average and continuous emissions. Exhaust gas analysis performed on a steady-state test is usually done with the gas sample continuously flowing through instruments. However, for transient cycle analysis, exhaust gases are either collected in bags for later steady-state analysis or continuous measurements are taken by fast-response analyzers. In the Engine and Emissions Research Center (EERC) at WVU, emissions for FTP cycle are measured continuously during the tests using various emission analyzers. Usually the emissions from the whole test are reported as mass of emissions per unit work (bhp-hr) for engine testing and mass of emissions per mile or gallon of fuel consumed for chassis dynamometer or on-road testing. In order to correlate the real-time emissions data (instantaneous) at each particular mode or phase of the test cycle and perform modal analysis, research has been done by Messer et al. [7]. A brief description of the research carried out by Messer et al. and then later by others is as given below.

\subsubsection{Theory of Delays}

There is significant delay between the point where the engine/vehicle experiences a certain operating condition, and the point in time at which the emissions related to that operating condition are measured and recorded using the conventional emissions measuring analyzers. This measurement delay results from a combination of the time due to the transport of exhaust gases from the engine to the appropriate gas analyzers and the response time of the analyzers. Each of the components in the sample train leads to measurement delays, and the sum of these delays should reflect the shift between expected and measured emissions transients. Mathematical models were developed using 
analyzer response times and appropriate fluid flow and heat transfer equations to predict the delay between engine transients and the resulting emissions response [8].

\subsubsection{Cross-correlation for Time Delay Calculation}

Cross-correlation is comparison of two sets of data against a common variable and calculation of the time shift that best matches the two sets, assuming a correlation exists between them. This method is used to calculate the measurement time delays involved in the sampling train by comparison of emissions with power assuming the emissions would increase with power. Ramamurthy [9] has used this cross correlation for modeling heavy-duty vehicle emissions inventory.

The correlation coefficients involving two sets of data can be calculated using the following equation

$$
\prod_{\Delta t}=\frac{\sum_{\Delta t=-t \max }^{t \max -\Delta t}\left[P(t) C\left(t+\Delta t_{\text {average }}\right)\right]}{\sum_{\Delta t=-t \max }^{t \max -\Delta t}[P(t) C(t)]}
$$

\section{Equation 2}

where $\prod_{\Delta t}$ is the correlation coefficient, $\mathrm{P}(\mathrm{t})$ is the power, $\mathrm{C}(\mathrm{t})$ is the emission rate of the gas and $\Delta t_{\text {average }}$ is the time shift between signals.

It is a well-known fact that $\mathrm{CO}_{2}$ emissions increase with an increase in power since $\mathrm{CO}_{2}$ represents the fuel consumed during the operation. Also, $\mathrm{NO}_{\mathrm{x}}$ behaves in sympathy with power but there are exceptions. A high-speed low load set point may produce more $\mathrm{NO}_{\mathrm{x}}$ than low speed, high load for the same engine power rating. The above equation when applied for the calculation of time delays for emissions calculation, representing the window of delay time $(\Delta t)$, as a function of power output level, takes the form as given by Equation 3 . 


$$
\prod_{\Delta t}=\frac{\sum_{\Delta t=-t \max }^{t \max -\Delta t}\left[P(t) C\left(t+\Delta t_{\max }-A^{*} P(t)\right]\right.}{\sum_{\Delta t=-t \max }^{t \max -\Delta t}[P(t) C(t)]}
$$

Equation 3

where $\Delta t=\Delta t_{\max }-A * P$ and $\Delta t_{\max }=\Delta t_{\text {average }}+M$

This equation is used to determine the time shift, which is the average response time for the exhaust collection system to detect a change in emission gas levels [11].

\subsubsection{Dispersion Model}

According to Levenspiel [10], the Residence Time Distribution (RTD) approach to non ideal flow of fluids through the reactors, states that elements of fluid taking different routes through the reactor may require different lengths of time to pass through the vessel. The distribution of these times for the stream leaving the vessel is called the exit age distribution or the RTD of the fluid. An analogy is drawn between mixing in actual flow and a diffusion process and is called the dispersion model.

During the process of mixing in a flow the molecules get shuffled or redistributed due to slippage or formation of eddies. This is repeated continuously whenever a fluid flows through a vessel and so it is compared to a molecular diffusion. Fick's Law defines the molecular dispersion in one direction and is given by

$$
\frac{\partial C}{\partial t}=d \frac{\partial^{2} C}{\partial^{2} x^{2}}
$$

\section{Equation 4}

where $\mathrm{d}$, the coefficient of molecular diffusion, is a parameter which uniquely characterizes the process. This law is generalized to all contributions to backmixing of fluid flowing in the $\mathrm{x}$ direction and is defined by

$$
\frac{\partial C}{\partial t}=D \frac{\partial^{2} C}{\partial^{2} x^{2}}
$$

\section{Equation 5}

where $\mathrm{D}$ is the longitudinal or axial dispersion coefficient, characterizing the backmixing during the flow. 
In dimensionless form the differential equation representing the dispersion model can be given as

$\frac{\partial C}{\partial \theta}=\left(\frac{\partial^{2} C}{\partial z^{2}}\right) \frac{D}{u L}-\frac{\partial C}{\partial z}$

Equation 6

where $Z=(u t+x) / L$ and $\theta=t u / L$, D being the diameter of the tunnel(vessel) with the fluid flowing in an average velocity $\mathrm{u}$ at an arbitrary distance $\mathrm{x}$ through the tunnel of length $\mathrm{L} . \mathrm{D} / \mathrm{uL}$ is called the vessel dispersion number and it measures the extent of axial dispersion.

If a pulse input is imposed into the flowing fluid then dispersion modifies the pulse and can be modeled as

$$
C_{i}=\frac{1}{\left.2 \sqrt{\pi \theta_{i}(D / u L}\right)} \exp \left\lfloor-\frac{\left(1-\theta_{i}\right)^{2}}{4 \theta_{i}((D / u L)}\right\rfloor
$$

Equation 7

where $C_{i}$ is the concentration of the dispersion model at a time $t_{i}$ and $\theta_{i}$ is the ratio of $u t / L$. Jarrett et al. [12] showed that the shape of the above equation was quite like the actual dispersion in previous work relating opacity and CO. It was acknowledged that the precise nature of the $\mathrm{NO}_{\mathrm{x}}$ or $\mathrm{CO}$ signal due to the flow and the analyzer response was unknown.

In order to improve the correlation of the transient emission component signals with power, Ramamurthy used this dispersion model. The tunnel, sample lines and the analyzers dispersed $\mathrm{NO}_{\mathrm{x}}$ and $\mathrm{CO}_{2}$ emission signals whereas power was not dispersed because it was directly measured at the axle. To correlate these emissions signals with power they had to be "back transformed." Instead of back-transforming the emissions signals, power was dispersed using the dispersion model assuming that it traveled through the tunnel (which was not true in the real-world conditions). A Gaussian distribution was assumed for the spreading of power in the tunnel. The dispersion model 
developed by Levenspiel was then applied to predict the axial dispersion of power at the downstream point where the $\mathrm{NO}_{\mathrm{x}}$ or $\mathrm{CO}$ analyzer was located.

Later, Ganesan et al. [13] used the same dispersion model for predicting the instantaneous engine out $\mathrm{NO}_{\mathrm{x}}$ emissions and relating them to various transient engine events. However, the spreading of power in the tunnel was assumed to follow a Gamma distribution unlike the Gaussian distribution used by Ramamurthy. Data were obtained to relate injections of $\mathrm{CO}_{2}$ into a dilution tunnel with analyzer measurements. The analyzer response was found to match a gamma distribution of the input pulse, so that the analyzer output could be modeled from the tunnel $\mathrm{CO}_{2}$ input. A Relationship between measured carbon dioxide and diffused power was established for a heavy-duty engine and was used to predict instantaneous emissions of carbon dioxide for various engine test cycles. The gamma function was then used to diffuse the implied carbon dioxide concentrations to yield a modeled analyzer output. $\mathrm{NO}_{\mathrm{x}}$ was modeled assuming it follows the same pattern with power as $\mathrm{CO}_{2}$. 


\section{Chapter 3 Experimental Procedure and Apparatus}

\subsection{Introduction}

In this chapter a detailed description of the EERC at West Virginia University is given. The test engines and test methods used for this research are also described.

\subsection{Description of EERC}

The Engine and Emissions Research Laboratory at West Virginia University was built according to the procedures described in the Code of Federal Regulations (CFR) 40, Part 86, Subpart N [14]. This laboratory was built in 1993 and has been in operation since then. A schematic of the WVU, EERC is as shown in Figure 2. The Laboratory uses a full-flow dilution tunnel critical flow venturi (CFV) constant volume sampling (CVS) system. Description of the apparatus used for engine testing and emissions measurement is followed. 


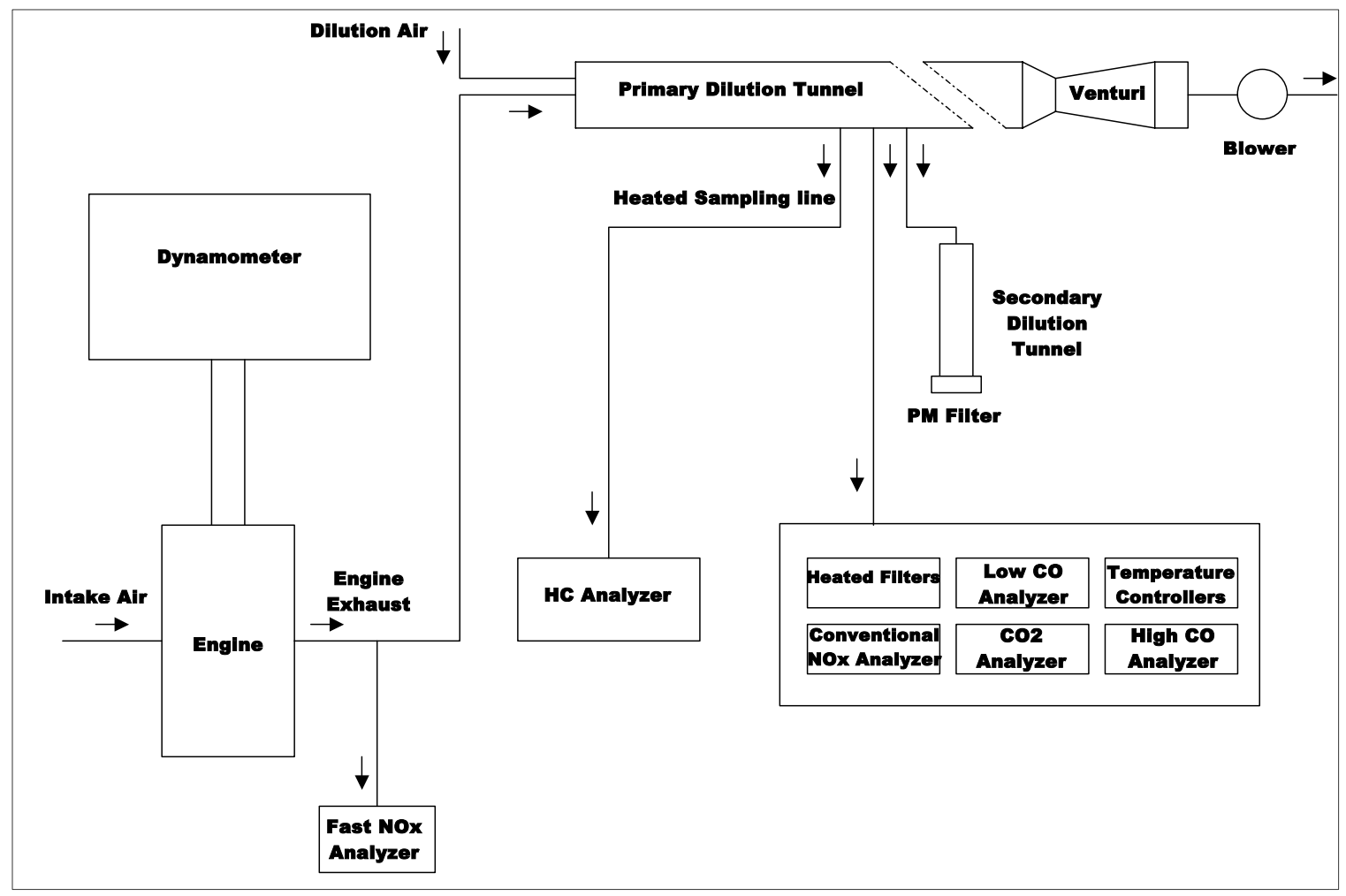

Figure 2 A schematic of the WVU EERC

\subsubsection{Engine Dynamometer}

Load is applied to and absorbed from the engine using an engine dynamometer. This is to simulate real-world driving conditions based on transient and steady cycles. The dynamometer used was a DC General Electric (GE) model DYC-243 engine dynamometer. The GE dynamometer was capable of absorbing $550 \mathrm{hp}$ and providing 500hp during motoring and could run up to a speed of 3000 RPM. Torque was measured using a load cell, attached to an arm of known length, which measured force. Engine speed was determined via a digital encoder inside the dynamometer. The engine was connected to the dynamometer by a drive shaft and a rubber coupling.

\subsubsection{Full Flow Dilution Tunnel}

The purpose of a dilution tunnel was to simulate the effect of emissions under real-world conditions and aid initial PM formation. This was done by mixing the raw 
emissions from the engine with conditioned ambient air in the dilution tunnel. Dilution also reduced the dew point temperature of the exhaust and prevents water condensation. The dilution tunnel was 18 inches in diameter and 15 feet long and was made of stainless steel. An orifice of 10 inches, for proper mixing of the exhaust and the dilution air, was placed at a distance of 3 feet from the tunnel entrance. Sample lines for the analyzers were taken at a distance of 15 feet (10 diameters) from the entrance of the tunnel. Flow through the dilution tunnel was turbulent and depended on the number of venturis open while testing. The exhaust was directed to the center of the dilution tunnel and was pulled through the tunnel by a $75 \mathrm{hp}$ blower. There were four critical flow venturis to control the flow in the dilution tunnel. One of them was rated at a flow of $400 \mathrm{scfm}$ and the other three at $1000 \mathrm{scfm}$. Any multiple of the flow rates could be achieved. For this research different flow rates were used depending on the test engine and test cycle.

\subsubsection{Air and Fuel Flow Metering}

Fuel and airflow measurements were needed for calculating engine exhaust flow. The EERC used the Max Machinery, Inc. Max Model 710 fuel conditioning system to meter fuel and a Meriam Instruments laminar flow element (LFE) Model 50MC2-6 to measure engine intake air. A brief description of these instruments is given below.

The fuel metering system comprised a filter, vapor eliminator, level controller, flow meter, heat exchanger, two pumps, two regulators, pressure relief valves, several pressure gauges and a thermocouple. A transfer pump was used to draw fuel from the tank and supply it to the vapor eliminator and flow meter at a steady pressure controlled by a 20psi pressure regulator. A K-type thermocouple measured the temperature of the fuel for mass flow calculations. Excess fuel not sent to the flow meters was routed through a heat exchanger to provide cooling for engine return fuel and then was sent back to the fuel tank. Fuel from the flow meter was combined with cool return fuel from the engine in the 
level controller where a second pump could be activated to provide adequate supply pressure for fuel injection systems. This system interfaced with the data acquisition system to obtain accurate fuel measurements.

The LFE was used to measure the intake airflow rate. Differential pressure across the element, absolute pressure and temperature of the air at the inlet were measured and related to the flow. The inlet pressure was adjusted with a butterfly valve placed upstream of the LFE. A remote butterfly valve was placed in the exhaust piping close to the engine to adjust exhaust backpressure to the engine manufacturer's specifications [16].

\subsubsection{Critical Flow Venturi}

Critical flow venturis were used to maintain a specified flow rate through the dilution tunnel. The theory behind critical flow venturis is that the mass flow rate of the gas in the dilution tunnel is held constant by the venturis once the flow at the throat reaches sonic conditions.

The mass flow rate through venturis was calculated using the equation $Q=K_{v} \frac{P}{\sqrt{T}}$,

Equation 8

where Q was the mass flow rate in scfm, $\mathrm{K}_{\mathrm{v}}$ was the calibration coefficient, $\mathrm{P}$ was the absolute pressure at the inlet of the venturi in $\mathrm{kPa}$ and $\mathrm{T}$ was the absolute temperature of the gas at the inlet of the venturi in $\mathrm{K}$. The temperature was measured with a 3-wire resistance temperature detector (RTD) and the pressure was measured via a Viatran absolute pressure transducer. A differential pressure gauge was used to ensure that the venturi was operating under sonic conditions. Flow through the venturi was nearly constant but varied a bit depending on the test. For example with a flow set to $3000 \mathrm{scfm}$ in the EERC while performing an FTP cycle for a DDC engine, it varied about $450 \mathrm{scfm}$ during the test. 


\subsubsection{Constant Volume Sampling}

The main purpose of a constant volume sampling system was to provide the same volume of diluted exhaust to each of the analyzers. A mixture of exhaust and dilution air was measured in the tunnel and samples were taken from the dilution tunnel through probes. Diaphragm pumps were used to pull the samples from the tunnel and then send them into the analyzers. Heated sampling lines were used to transport the samples from the tunnel to the analyzers via the sample probes. The samples were maintained at specified temperatures using heated lines, heated probes heated filters and heated pumps. The $\mathrm{HC}$ sample was maintained at $375^{\circ}$ Fahrenheit $(\mathrm{F}), \mathrm{CO}$ and $\mathrm{CO}_{2}$ were maintained at $250^{\circ} \mathrm{F}$ and $\mathrm{NO}_{\mathrm{x}}$ at $235^{\circ} \mathrm{F}$. Temperature controllers maintained the preset temperatures of the heated lines, probes, pumps and filters. $\mathrm{CO}$ and $\mathrm{CO}_{2}$ were drawn through a chiller to extract the water from the sample that may have condensed in the system while in transport.

\subsubsection{Bag Sampling}

Emissions were continuously measured while the test was being performed. Samples were collected from the tunnel and sent into the analyzers during the course of the test. Dilute exhaust and the ambient air samples were also collected in two different bags for measurement. The bag used for collecting dilute exhaust from the tunnel was called dilute bag and the one used for collecting the ambient air was called the background bag. Each of the bags was made of Tedlar and had a capacity of 80 liter. The flow rate of the sample into the bag was predetermined prior to the test to provide an accurate sample with regards to the duration of the test. The background bag was sampled from the entrance of the tunnel and signified the concentration of emissions present in the dilution air. The dilute bag was a sample taken from the tunnel during the test and represented an integrated concentration of the emissions present in the tunnel. 
The concentration of the emissions in the background was then subtracted from the emissions continuously collected (during the test) and the emissions from the dilute bag using the governing equations in CFR 40 Part 86, to represent the concentration of gases emitted from the engine.

\subsubsection{Data Acquisition System}

EERC used an in-house developed data acquisition and data reduction system. Data were acquired from analyzers, thermocouples and pressure transducers using RTI815 analog to digital data acquisition boards along with 3-B signal conditioning modules and a computer. Data obtained from the data acquisition system was in the form of ADC (Analog to Digital Codes). This data was then converted to engineering units using the data reduction software. The data reduction software was a Visual Basic program written based on the equations outlined in CFR 40 Part 86 for emissions testing. It calculated the emissions concentration, mass and brake specific mass. Airflow, temperatures, pressures and fuel flow were also calculated by the data reduction software and the output was given in the form of a Microsoft excel spreadsheet.

\subsection{Emissions Measurement}

The measurement of exhaust emissions was done using different gas analyzers and particulate matter (PM) sampling systems. The analyzers at EERC were fixed to a bench as shown in Figure3. 


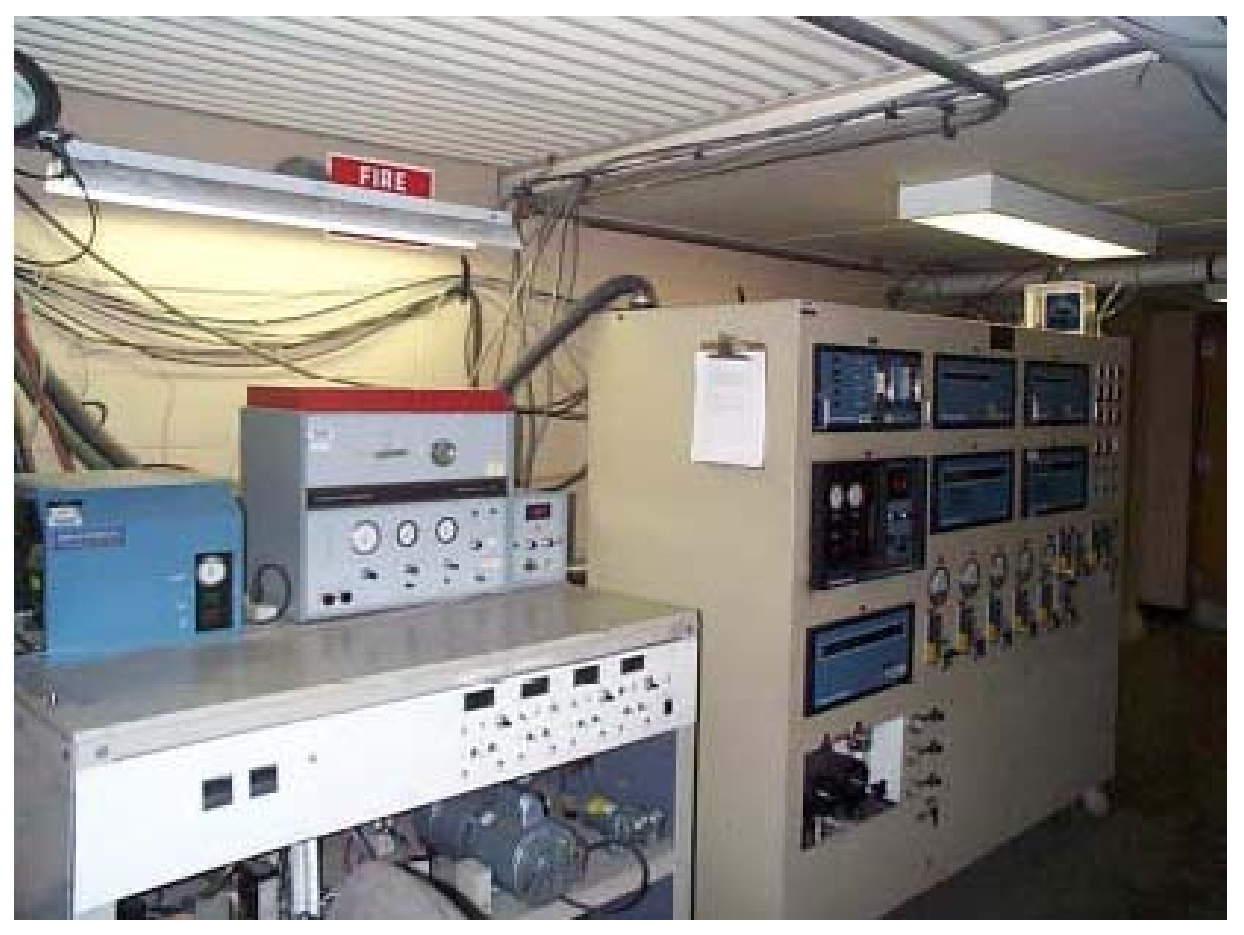

Figure 3 Analyzer bench in the EERC at WVU

The EERC was capable of measuring $\mathrm{HC}, \mathrm{NO}_{\mathrm{x}}, \mathrm{CO}, \mathrm{CO}_{2}, \mathrm{SO}_{2}, \mathrm{O}_{2}$ and $\mathrm{PM} . \mathrm{SO}_{2}$ and $\mathrm{O}_{2}$ were not measured because they do not provide much information for diesel engines. The tests conducted for this research measured $\mathrm{HC}, \mathrm{CO}, \mathrm{CO}_{2}$, and $\mathrm{NO}_{\mathrm{x}} . \mathrm{NO}_{\mathrm{x}}$ data obtained from two different analyzers was used for analysis. For calibrating the analyzers, gas bottles with different concentrations were used depending on the test engine and the test cycle.

\subsubsection{Emissions Analyzers}

\subsubsection{Hydrocarbon (HC) analyzer}

The $\mathrm{HC}$ analyzer used at EERC was a Flame Ionization Detector (FID), Beckman Model 402 Hydrocarbon Analyzer. The sample for the HC analyzer was pulled from the dilution tunnel at approximately 2 liters per minute and was maintained at a constant $375^{\circ}$ F, as specified by CFR 40 Part 86 . The HC analyzer used the principle of flame ionization detection, which is described in Section 2.1.3. The HC analyzer was checked 
for zero (using zero air) and full-scale span (using a known concentration of propane) before each test. The zero air was generated from a Balston 75-52 FT-IR purge gas generator and propane was supplied as a compressed gas in bottles.

\subsubsection{2 $\mathrm{CO}_{2}$ Analyzer}

The measurement of $\mathrm{CO}_{2}$ was done using a Beckman Industrial Model 868 nondispersive infrared analyzer (NDIR). The NDIR method is described in detail in Section 2.1.3. The NDIR method had a limitation of water interference in its measurement. To overcome this, the sample was dried prior to entering the analyzer by passing it through a chiller. The temperature of the sample line was maintained at $250^{\circ} \mathrm{F}$. A constant flow rate and a pressure drop of 0.2 inches of water were held across the analyzer. Zeroing and spanning were done before each test. $\mathrm{N}_{2}$ gas was used for zeroing.

\subsubsection{CO Analyzer}

$\mathrm{CO}$ was measured as low $\mathrm{CO}$ and high $\mathrm{CO}$. Both were based on the NDIR measurement technique. Models used were Horiba, AIA-210 and Rosemount 860, CO analyzers. $\mathrm{CO}$ analyzers used the same sampling lines as $\mathrm{CO}_{2}$ analyzer. A temperature of $250^{\circ} \mathrm{F}$ was maintained in the sampling line. A pressure drop of 0.2 inches of water was also maintained across the analyzers. Pure $\mathrm{N}_{2}$ was used for zeroing and a known concentration of $\mathrm{CO}$ was used for spanning.

\subsubsection{PM Sampling}

PM sampling in EERC is done in two different ways. The continuous PM emissions were measured using a Tapered Element Oscillating Microbalance (TEOM) and the integrated test cycle emissions are measured gravimetrically using Pallflex membrane filters fitted to the secondary dilution tunnel. 


\subsubsection{NOx Analyzers}

The present research was focused on the measurement of $\mathrm{NO}_{\mathrm{x}}$. There were basically two analyzers used for the measurement of $\mathrm{NO}_{\mathrm{x}}$.

1.Rosemount Model $955 \mathrm{NO}_{\mathrm{x}}$ analyzer

2.Cambustion fast $\mathrm{NO}_{\mathrm{x}}$ analyzer

A detailed description of these analyzers is given below

\subsubsection{Rosemount Model 955 $\mathrm{NO}_{\mathrm{x}}$ analyzer}

This analyzer was based on the principle of chemiluminescence, which is described in Section 2.1.3 in detail. This analyzer was capable of measuring both NO and $\mathrm{NO}_{\mathrm{x}}$ (as a combination of $\mathrm{NO}$ and $\mathrm{NO}_{2}$ ). During the process of engine testing and emissions measurement, the exhaust sample was drawn from the dilution tunnel at a constant temperature of $235^{\circ} \mathrm{F}$. The sample was filtered and supplied to the $\mathrm{NO}_{\mathrm{x}}$ analyzer at a constant pressure of 4 psi. The voltage was set for 0 to 5 volts. The $\mathrm{NO}_{\mathrm{x}}$ analyzer could be changed to two different modes for measuring $\mathrm{NO}$ and $\mathrm{NO}_{\mathrm{x}}$. For the measurement of $\mathrm{NO}_{\mathrm{x}}$, the sample was routed through a $\mathrm{NO}_{\mathrm{x}}$ converter before leading it into the analyzer.

The Cambustion fast $\mathrm{NO}_{\mathrm{x}}$ analyzer is described in detail in Section 3.4.

\subsection{Cambustion Fast $\mathrm{NO}_{\mathrm{x}}$ Analyzer}

The fast $\mathrm{NO}_{\mathrm{x}}$ analyzer $\mathrm{fNO}_{\mathrm{x}} 400$ was designed to measure concentrations of $\mathrm{NO}$ with a response of around $4 \mathrm{~ms}$. The faster response made it suitable for several transient engine tests. Figure 4 shows the fNOx 400 unit. 


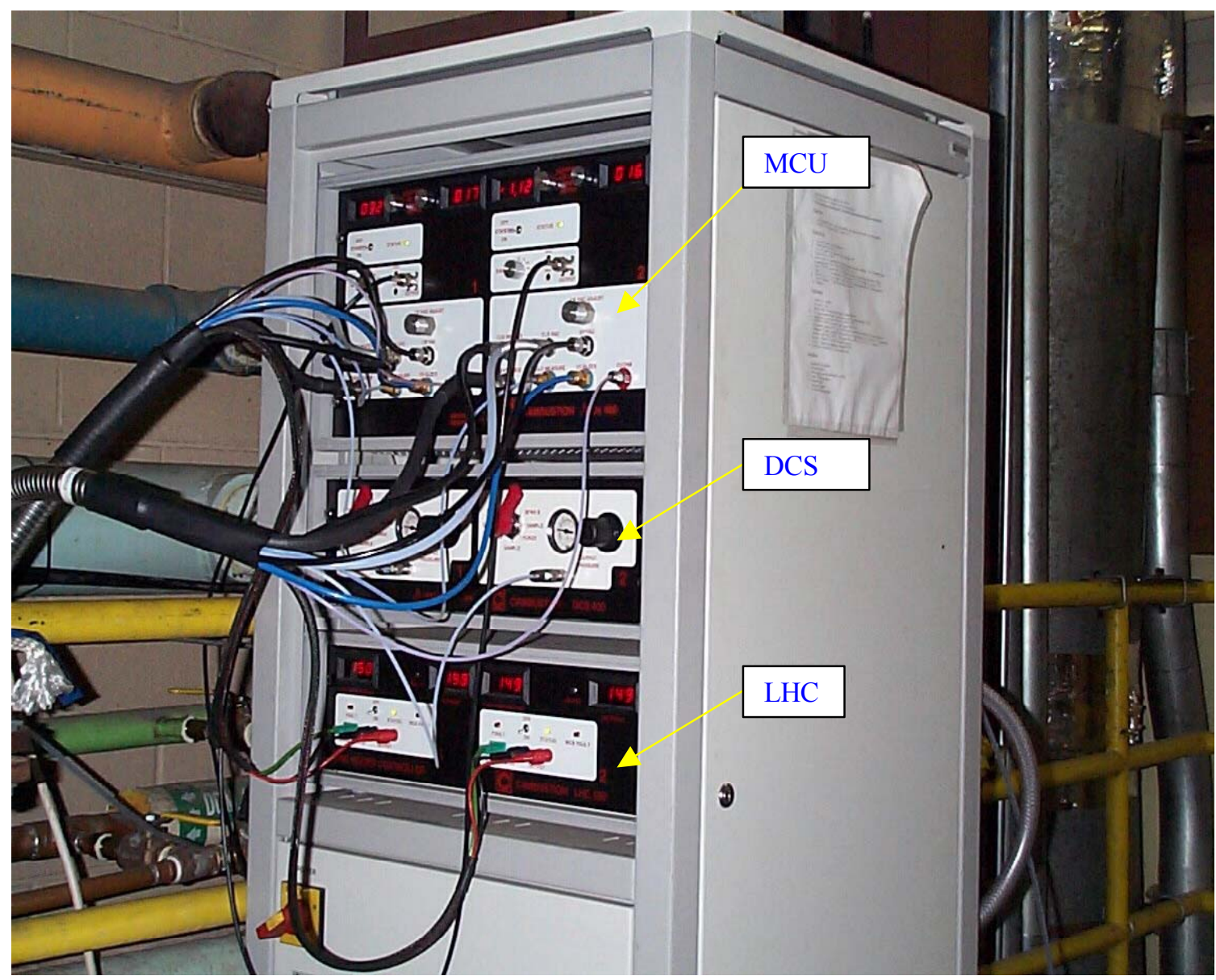

Figure 4 Fast $\mathrm{NO}_{\mathrm{x}}$ sampling unit taking fast $\mathrm{NO}_{\mathrm{x}}$ data

\subsubsection{Apparatus Description}

A remote sampling head was mounted close to the sample source in the engine exhaust and coupled to it via a heated sample probe. The sample head contained an intermediate chamber (constant pressure (CP) chamber), which removed the effect of pressure fluctuations. From the CP chamber, a portion of the sample flow was drawn into the reaction chamber where it met a controlled flow of ozone. This light was collected via a fiber optic cable and measured at the Main Control Unit (MCU) by a photo-multiplier. With the correct operating parameters, the light emission was very nearly proportional to the concentration of NO in the sample [17]. 


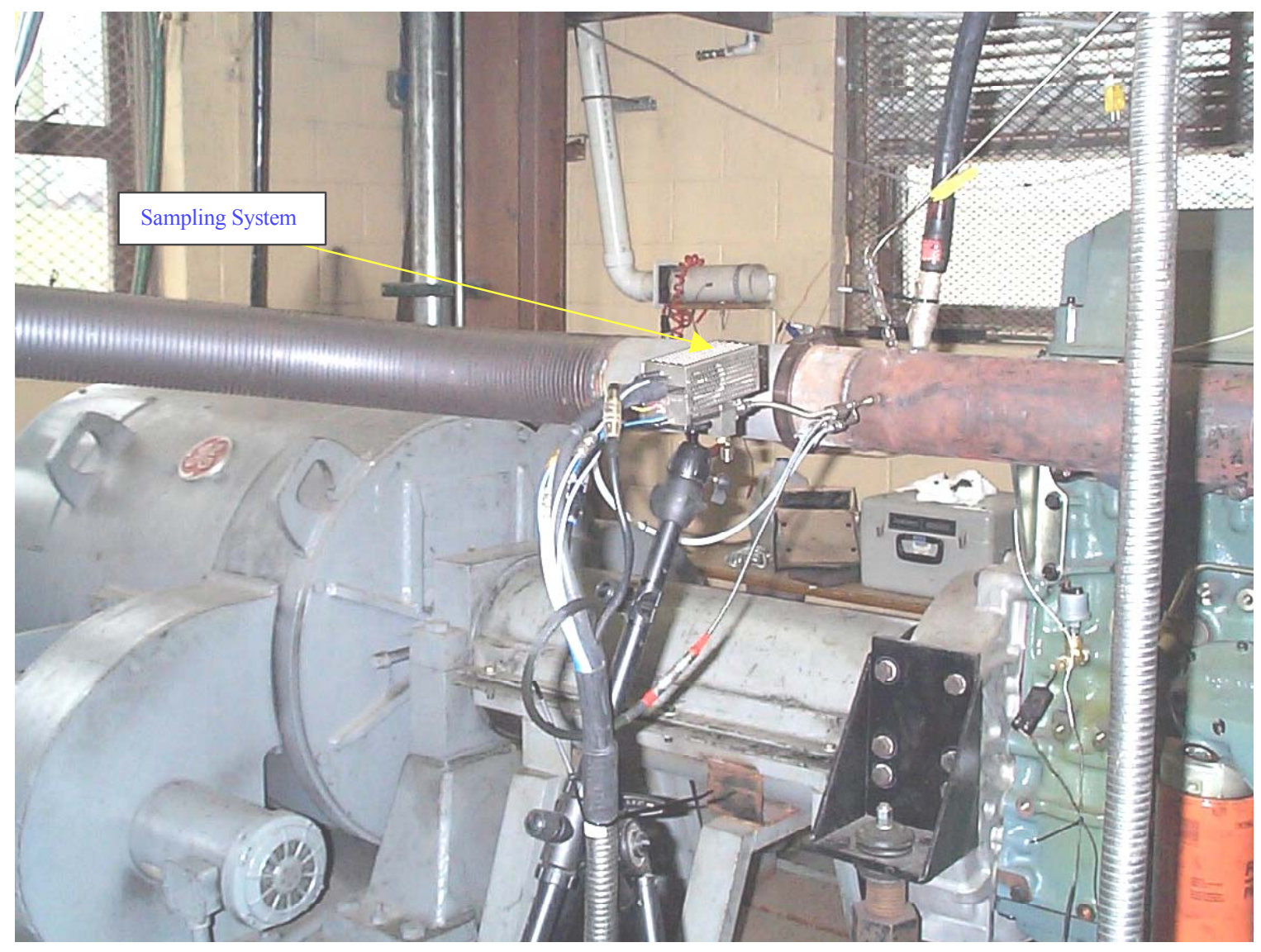

Figure 5 Fast $\mathrm{NO}_{\mathrm{x}}$ analyzer's remote sampling head mounted into exhaust pipe of the DDC Series 60 engine for fast $\mathrm{NO}_{\mathrm{x}}$ sampling.

Fast NO analyzer had the following main components

1. Sampling System

2. Main Control Unit (MCU)

3. Dynamic Calibration System (DCS)

4. Line Heater Controller (LHC)

5. Ozone Generator

6. Vacuum pump

\subsubsection{Sampling System}

The chemical reaction with NO and ozone took place inside the sampling head. It contained a reaction chamber and a constant pressure chamber. The sample entered into the sampling head via a heated sampling probe at a flow rate of about $11 / \mathrm{min}$. The sampling probe was connected to the engine exhaust manifold (for raw sampling) or to the dilution tunnel (for dilute sampling) via a $1 / 4$ inch compression fitting. Inside the sampling head the sample was made to pass through a constant pressure chamber (CP 
chamber) to overcome the effect of pressure fluctuations. The $\mathrm{CP}$ chamber was maintained at $350 \mathrm{mmHg}$ below atmosphere. From the CP chamber the sample passed into the reaction chamber at a rate of $80 \mathrm{cc} / \mathrm{min}$ (Standard Temperature and Pressure$\mathrm{STP})$ via a CLD tube. The chemiluminescence reaction took place in the reaction chamber. An ozone generator supplied ozone required for the reaction. Temperature of the sampling head was maintained at $300^{\circ} \mathrm{C}$ with the help of thermocouples and temperature controllers and a heating element.

\subsubsection{Main Control Unit}

The MCU controlled all the main functions of the analyzer. The light emitted from the reaction between $\mathrm{NO}$ and $\mathrm{O}_{3}$ was carried into the $\mathrm{MCU}$ by a fiber optic cable. The $\mathrm{MCU}$ contained a photo-multiplier detector, which measured the emitted light and thus gave a measure of the amount of NO in the sample. The MCU contained two main sub-systemsthe gas handling sub-system and the electronic sub-system. The gas handling sub-system provided the sample head with its ozone and vacuum requirements and the functions of the electronic sub-system were detection and amplification of the chemiluminescence signal and monitoring/controlling of temperature and pressure in the sample head and a heating element.

\subsubsection{Dynamic Calibration System (DCS)}

Calibration of the fast $\mathrm{NO}_{\mathrm{x}}$ analyzer was done using the DCS system. DCS used a simple but rigorous technique for calibration during the engine running without the need to disturb the calibration sample line. This was achieved by subjecting the span gas at the sample tube tip to the same temperature and pressure perturbations as were present at the sampling point using a calibration adapter. The DCS not only calibrated the system but 
also took into account the elements of sample pressure independence and sample system blockage.

\subsubsection{Line Heater Controller (LHC)}

The fast $\mathrm{NO}_{\mathrm{x}}$ analyzer was a wet chemiluminescent analyzer i.e., the sample was not dried prior to passing it into the analyzer. Hence, it may have contained water vapor and other condensing species like hydrocarbons, which were liable to condense in the sampling lines. In order to avoid the condensing of these, the sampling line was maintained at a constant temperature of $150^{\circ} \mathrm{C}$, which was taken care of by the LHC. The sample was heated ohmically by a low voltage, phase-angle triggered AC supply, controlled by a PID system to achieve the desired operating temperature.

Specifications of the fast $\mathrm{NO}_{\mathrm{x}}$ analyzer are given in Table2.

Table 2 Fast NOx (fNOx 400) analyzer specifications

\begin{tabular}{|l|l|}
\hline Sensitivity & $0.1 \mathrm{mV} / \mathrm{ppm}$ to $50 \mathrm{mV} / \mathrm{ppm}$ \\
\hline Linearity & $\begin{array}{l} \pm 1 \% \text { of full scale to } 50000 \mathrm{ppmNO} \\
\pm 2 \% \text { of full scale to } 10000 \mathrm{ppmNO}\end{array}$ \\
\hline Noise & rms $<1 \%$ of mean for $1000 \mathrm{ppmNO}$, gain 20 \\
\hline Quenching & Approx. $0.5 \%$ loss in signal per $1 \% \mathrm{CO}_{2}$ in the sample \\
\hline Response time & $90 \%-10 \% \sim 4 \mathrm{~ms}$ with a standard sampling configuration \\
\hline Ranges & $500,200,100,50,20,10,5,2,1 \mathrm{~V} / \mathrm{mA}$ \\
\hline Output Voltage & -10 to $+10 \mathrm{~V}$ \\
\hline Vacuum & Pumping capacity $\sim 15 \mathrm{~m}^{3} / \mathrm{hr}$, sealed inlet capacity $<0.5$ mbar \\
\hline Sample & $\begin{array}{l}\sim 11 / \mathrm{min}, \text { determined } \mathrm{by} \text { sample tube dimensions and vacuum level. } \\
\text { Sample flow into the CLD chamber is around } 80 \mathrm{cc} / \mathrm{min}(\mathrm{STP})\end{array}$ \\
\hline Power & $107-127 \mathrm{~V}$ AC, $220-250 \mathrm{VAC}$ \\
\hline $\begin{array}{l}\text { Ambient } \\
\text { Temperature }\end{array}$ & $0-45 \mathrm{C}$ \\
\hline
\end{tabular}




\subsubsection{Method of calibration of the fast NOx analyzer}

Depending on the test cycle and engine type, maximum concentration of $\mathrm{NO}_{\mathrm{x}}$ to be measured was determined. Then the span gases were chosen accordingly. Table 3 shows the span gas concentrations used for FTP cycles on different engines used for raw fast $\mathrm{NO}_{\mathrm{x}}$ sampling. Span gases were passed into the dynamic calibration system from the gas bottles using gas regulators and tubes connected using quick connects. The span gases maintained a constant pressure of 70 psi. The span gases from the DCS were sent into the sampling head containing the reaction chamber wherein the chemical reaction took place. The products of reaction were pulled back into the main unit using a vacuum pump and it was released into the atmosphere from a vent near the vacuum pump. Ozone was continuously circulated in the system at all times during the operation of the fast $\mathrm{NO}_{\mathrm{x}}$ unit. Zeroing was done using zero air. Zeroing and spanning were done before each test.

Table 3 Calibration gases used for the FTP cycle for the six heavy-duty diesel engines

\begin{tabular}{|l|l|}
\hline Engine & $\begin{array}{l}\text { Calibration gas bottle concentration (PPM) } \\
\text { for raw fast } \mathrm{NO}_{\mathrm{x}} \text { emissions }\end{array}$ \\
\hline DDC Series 60, 2000 Model Year & 2000 \\
\hline Caterpillar, 1996 Model Year & 1500 \\
\hline DDC Series 60, 1995 Model Year & 3500 \\
\hline Mack, 1995 Model Year & 2000 \\
\hline Volvo, 1998 Model Year & 1500 \\
\hline Navistar, 1999 Model Year & 2200 \\
\hline
\end{tabular}




\section{Chapter 4 Test Engines Specification Test Cycles and Test Methods}

Data for this thesis were collected from a wide variety of engines and a wide variety of test cycles. The test engines and test cycles are discussed in this chapter. All the tests were conducted by installing the engines on the DC dynamometer in EERC at WVU. Test cycles were mainly classified as steady-state test cycles, trapezoidal test cycles and transient test cycles.

\subsection{Test Engines Specifications}

The test engines were tested on various steady state and transient test cycles and the $\mathrm{NO}_{\mathrm{x}}$ emissions were measured. The engines used are

1. DDC Series 60, 2000 Model Year

2. Mack Truck Engine, 1995 Model Year

3. Volvo Truck Engine, 1998 Model Year

4. Caterpillar Engine, 1996 Model Year

5. DDC Series 60, 1995 Model Year

6. Navistar International Truck Engine, 1999 Model Year

Specifications for the engines are given below.

\subsubsection{Detroit Diesel Corporation (DDC) Series 60, 2000 Model year}

The DDC Series 60 is a turbocharged four stroke, high speed, diesel engine. Its specifications as given by the engine manufacturer are given in Table 4.

Table 4 DDC Series 60 engine specifications

\begin{tabular}{|l|l|}
\hline Engine Manufacturer & Detroit Diesel Corporation \\
\hline Engine Model & Series 60, 2000 Model Year \\
\hline Displacement & $12.7 \mathrm{~L}$ \\
\hline Power Rating & $500 \mathrm{HP} @ 2100 \mathrm{rpm}$, \\
\hline Torque Rating & $1735 \mathrm{lb}-\mathrm{ft} @ 1450 \mathrm{rpm}$ \\
\hline Bore X Stroke & 5.12 in X 6.3 in \\
\hline Configuration & Inline 6 cylinder \\
\hline Compression Ratio & $16.5: 1$ \\
\hline
\end{tabular}


The engine coupled to the dynamometer is shown in Figure 6. The engine was mapped in the EERC and the actual torque and power maps used for the testing are given in Figure 7

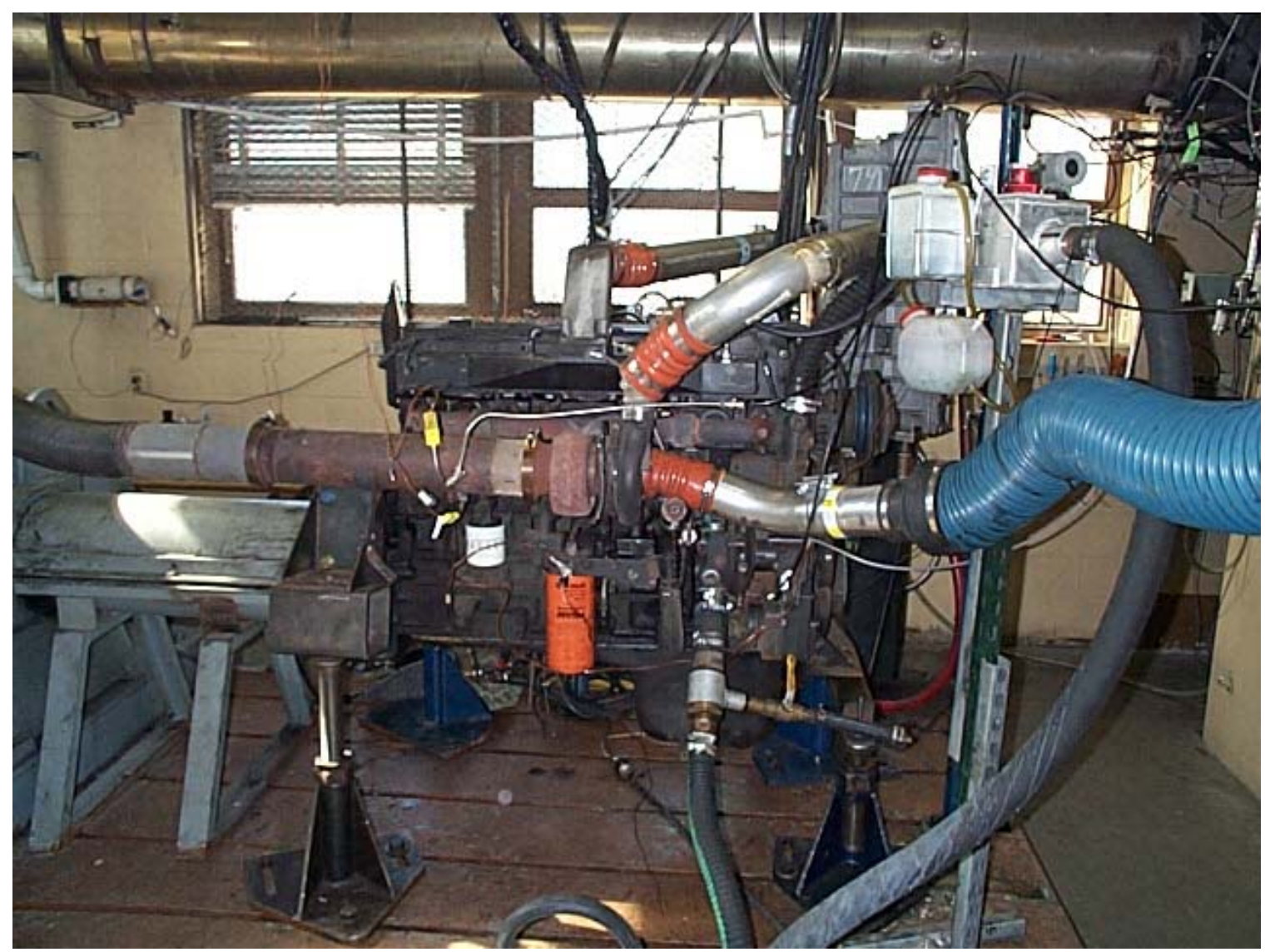

Figure 6 DDC Series 60 engine (2000 Model Year) coupled to the DC dynamometer in EERC at WVU. 


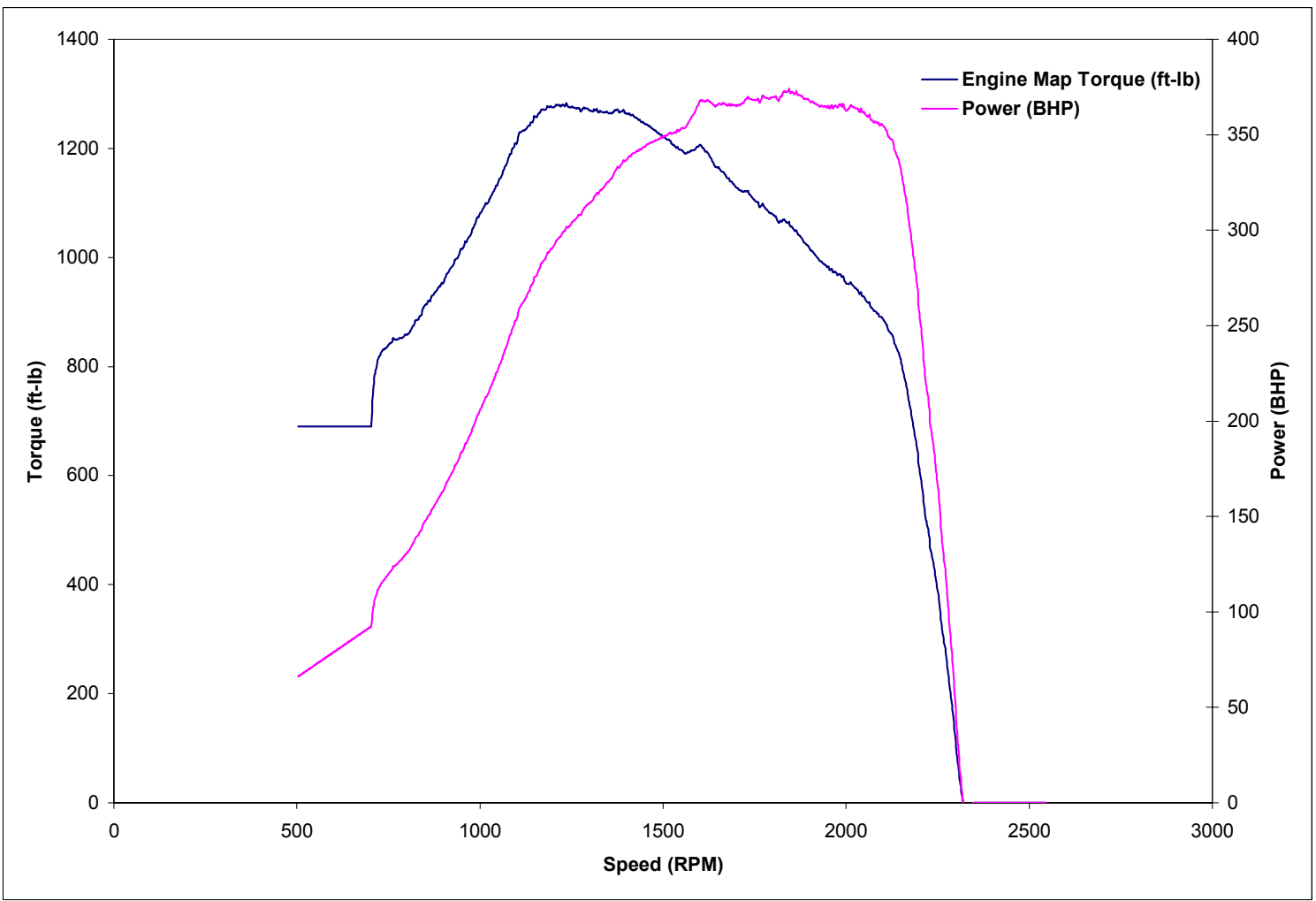

Figure 7 Engine map of the DDC Series 60 (2000 Model Year) engine.

\subsubsection{Mack Truck Engine, 1995 Model Year}

The Mack engine used for testing was removed from a Mack Truck and coupled to the dynamometer in the EERC at WVU for engine testing. It is a four stroke, turbocharged high-speed diesel engine. Its specifications as given by the engine manufacturer are tabulated in Table 5. The engine was placed in the engine test cell in the EERC at WVU and was mapped. The engine map is as shown in Figure 8.

\section{Table 5 Mack Truck engine specifications}

\begin{tabular}{|l|l|}
\hline Engine Manufacturer & Mack \\
\hline Engine Model & E7-400, Model Year 1995 \\
\hline Displacement & 12.01 L \\
\hline Power Rating & $400 \mathrm{HP} @ 1800$ RPM \\
\hline Torque Rating & 1460 lb-ft @ 1200 RPM \\
\hline Bore X Stroke & 4.875 in X 6.3 in \\
\hline Configuration & Inline 6 cylinder, turbo-charged \\
\hline Compression Ratio & $16.1: 1$ \\
\hline
\end{tabular}




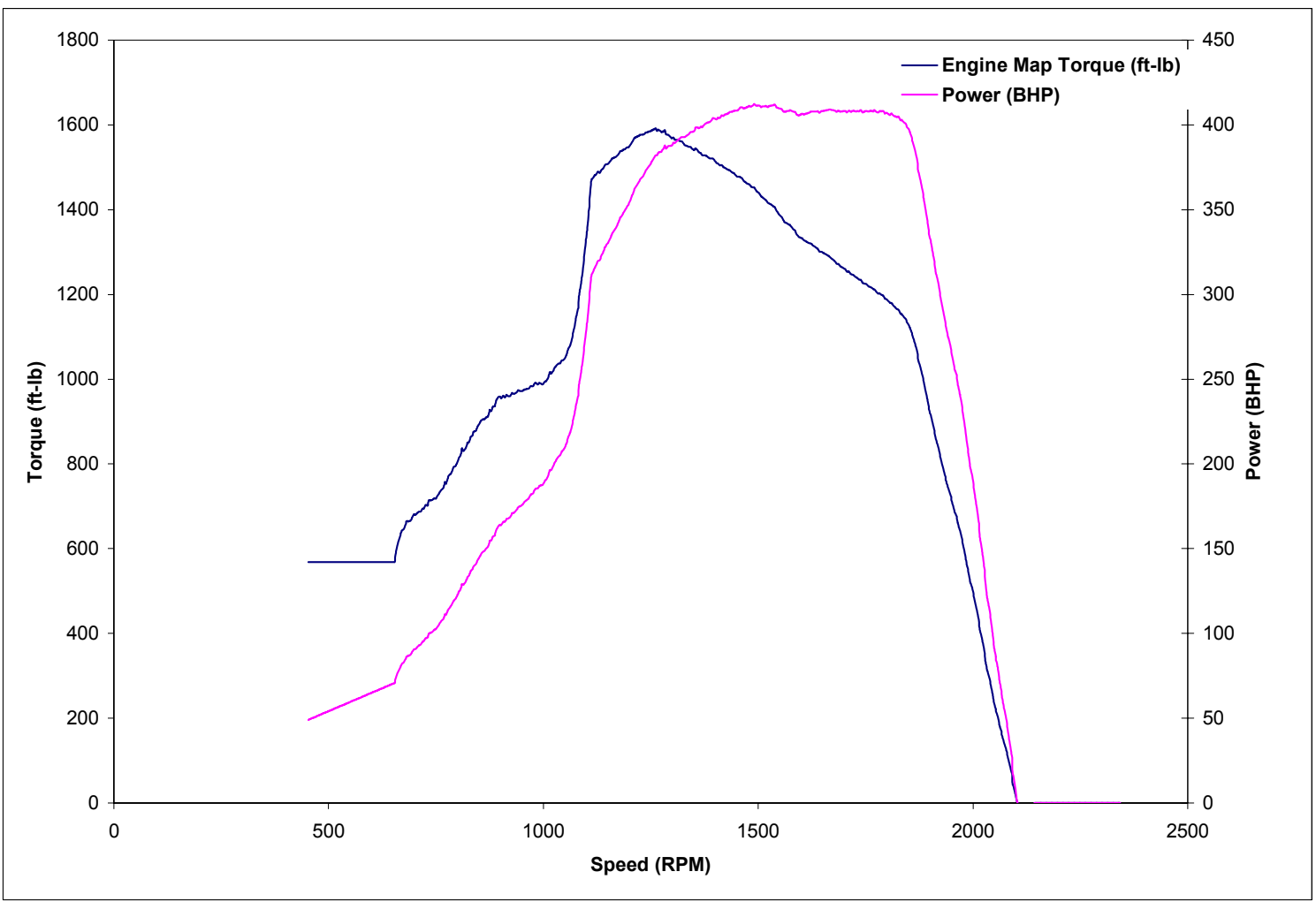

Figure 8 Engine map for the Mack Truck engine.

\subsubsection{Caterpillar Engine, 1996 Model Year}

The Caterpillar engine is a four-stroke, turbocharged, high-speed diesel engine.

The specifications of the engine as given by the manufacturer are tabulated in Table 6 .

Figure 9 shows the actual engine map when mapped in the EERC. 


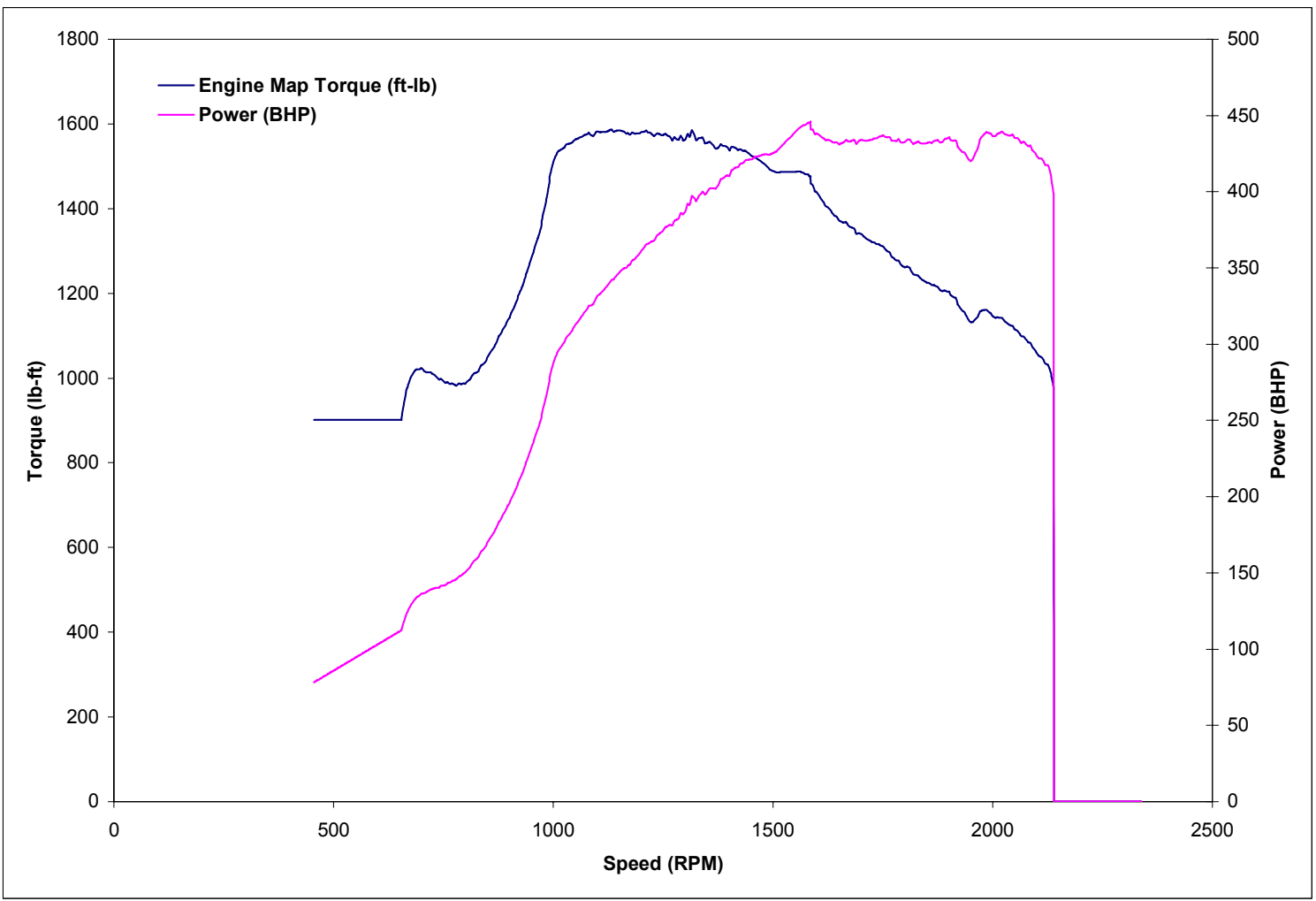

Figure 9 Engine map for the Caterpillar engine.

Table 6 Caterpillar engine specifications

\begin{tabular}{|l|l|}
\hline Engine Manufacturer & Caterpillar \\
\hline Engine Model & Cat 3406 E , 1996 \\
\hline Displacement & $14.6 \mathrm{~L}$ \\
\hline Power Rating & $475 \mathrm{HP} @$ 2100 RPM \\
\hline Torque Rating & $1650 \mathrm{lb}-\mathrm{ft}$ \\
\hline Bore X Stroke & 5.4 in X 6.5 in \\
\hline Configuration & Inline 6 cylinder, turbo-charged \\
\hline Compression Ratio & $16.5: 1$ \\
\hline
\end{tabular}

\subsubsection{Volvo Truck Engine, 1998 Model Year}

The Volvo truck engine is a four-stroke, turbocharged diesel engine. Its specifications as given by the manufacturer are in Table 7 and the actual engine map obtained by mapping it in the EERC, WVU, is as shown in Figure 10. 


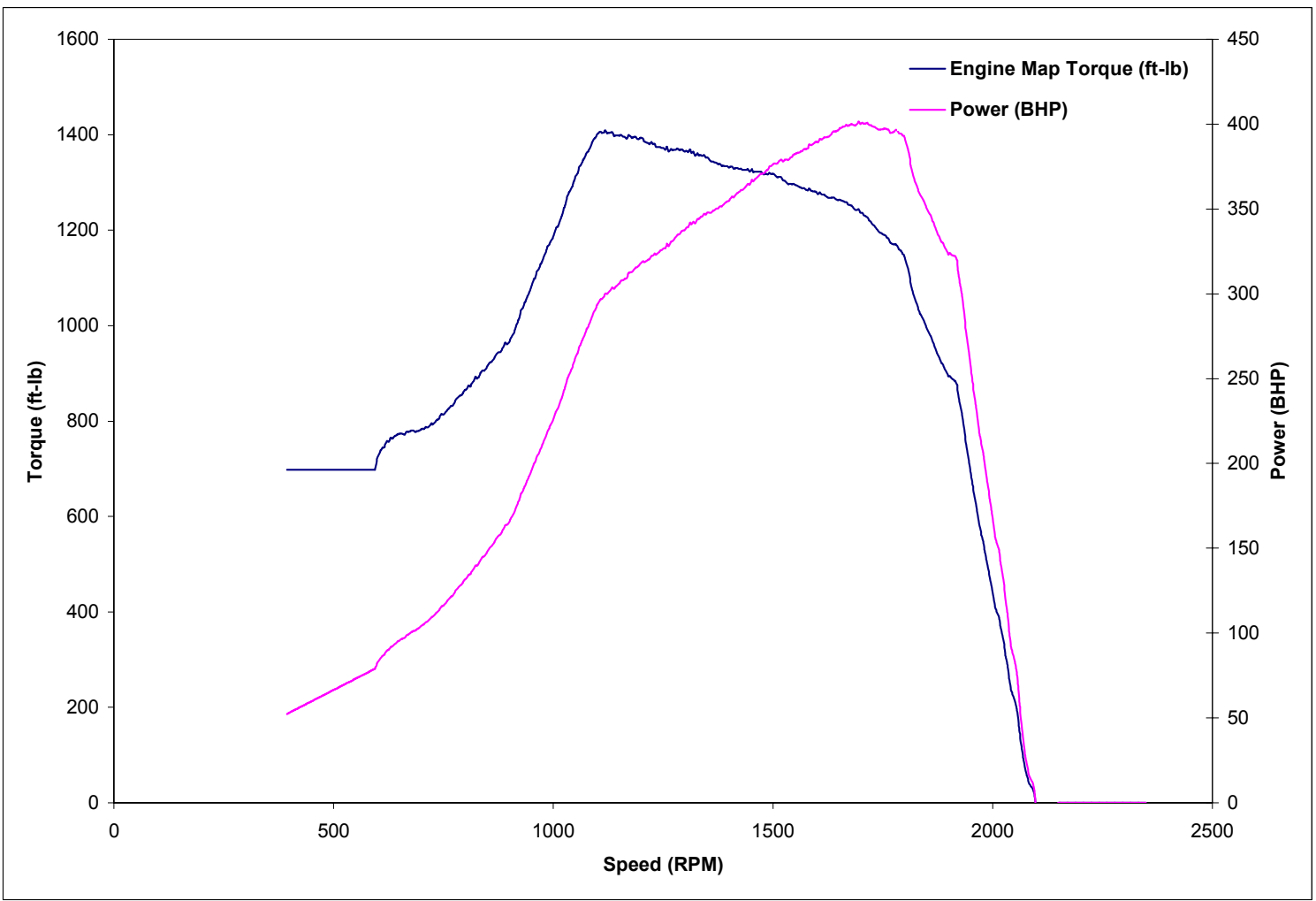

Figure 10 Engine map for the Volvo Truck engine.

Table 7 Volvo Truck engine specifications

\begin{tabular}{|l|l|}
\hline Engine Manufacturer & Volvo \\
\hline Engine Model & VED12B, 1998 \\
\hline Displacement & $12.1 \mathrm{~L}$ \\
\hline Power Rating & $425 \mathrm{HP} @ 1800 \mathrm{RPM}$ \\
\hline Torque Rating & $1450 \mathrm{lb}-\mathrm{ft} @ 1200 \mathrm{RPM}$ \\
\hline Bore X Stroke & 5.4 in X 6.5 in \\
\hline Configuration & Inline 6 cylinder, turbo-charged \\
\hline Compression Ratio & $17.3: 1$ \\
\hline
\end{tabular}

\subsubsection{Detroit Diesel Corporation (DDC) Series 60, 1995 Model Year}

The DDC Series 60 engine is a four-stroke, turbocharger, heavy-duty diesel engine. Figure 11 shows the engine map as obtained while mapping in the EERC WVU. The specifications of the engine as given by the manufacturer are as shown in Table 8 . 


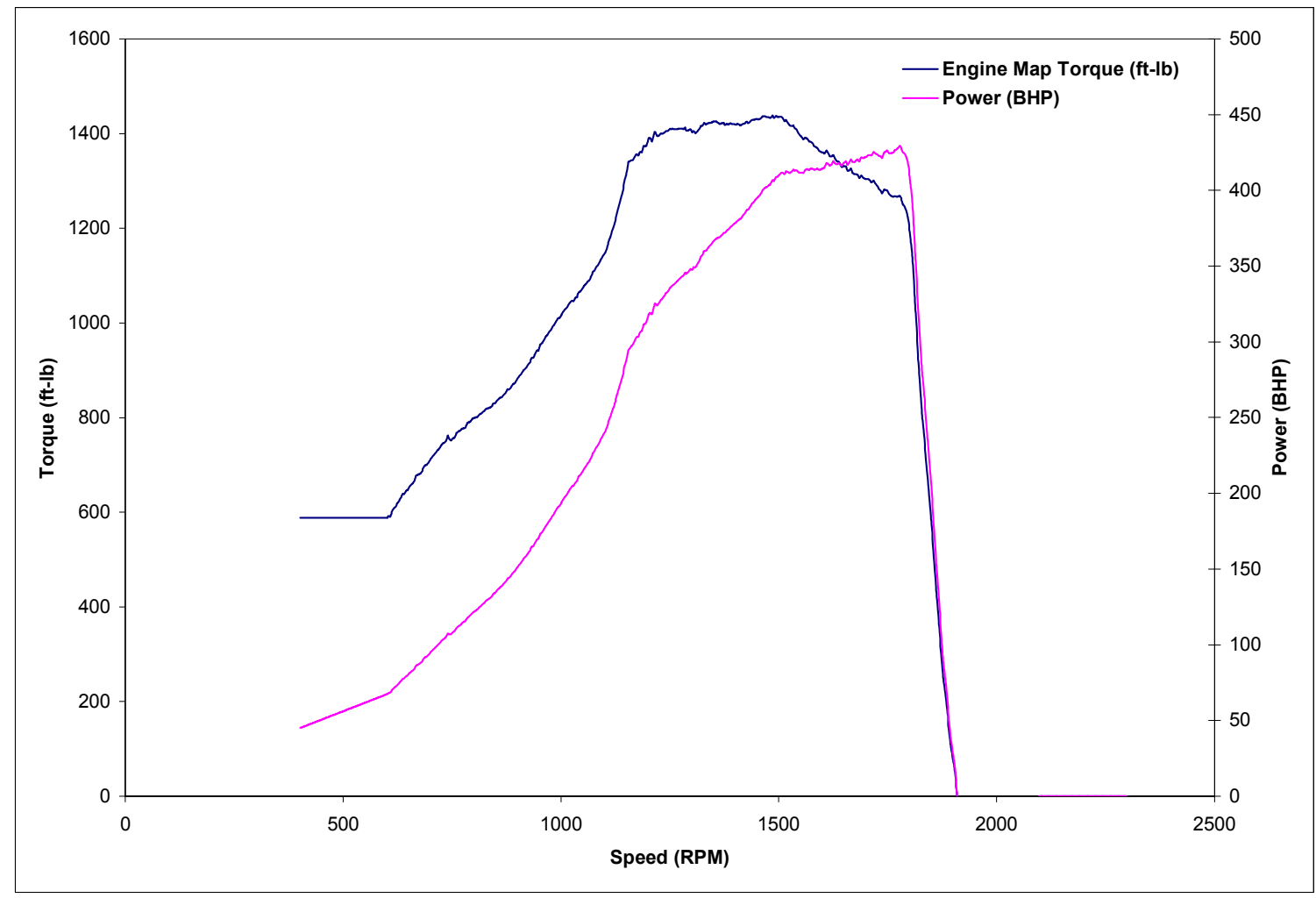

Figure 11 Engine map for the DDC Series 60 (Model Year 1995) engine.

Table 8 DDC Series 60 engine specifications

\begin{tabular}{|l|l|}
\hline Engine Manufacturer & Detroit Diesel Corporation \\
\hline Engine Model & Series 60, 1995 \\
\hline Displacement & $12.7 \mathrm{~L}$ \\
\hline Power Rating & $350 \mathrm{HP} @ 2100 \mathrm{RPM}$ \\
\hline Torque Rating & $1350 \mathrm{lb}-\mathrm{ft} @ 1200 \mathrm{RPM}$ \\
\hline Bore X Stroke & 5.12 in X 6.3 in \\
\hline Configuration & Inline 6 cylinder, turbo-charged \\
\hline Compression Ratio & $16.5: 1$ \\
\hline
\end{tabular}

\subsubsection{Navistar Engine, 1999 Model Year}

The Navistar engine used for the testing was removed from a WVU Ford truck. This engine is a four-stroke, turbocharged, heavy-duty diesel engine. Engine map of the Navistar engine run in EERC WVU is given in Figure 12. It is evident that the torque and power curves are cut-off at 3000 RPM. This is because the DC dynamometer coupled to the engine could not go above 3000 RPM even though the manufacturers specified torque and power curves go above 3000 RPM. 


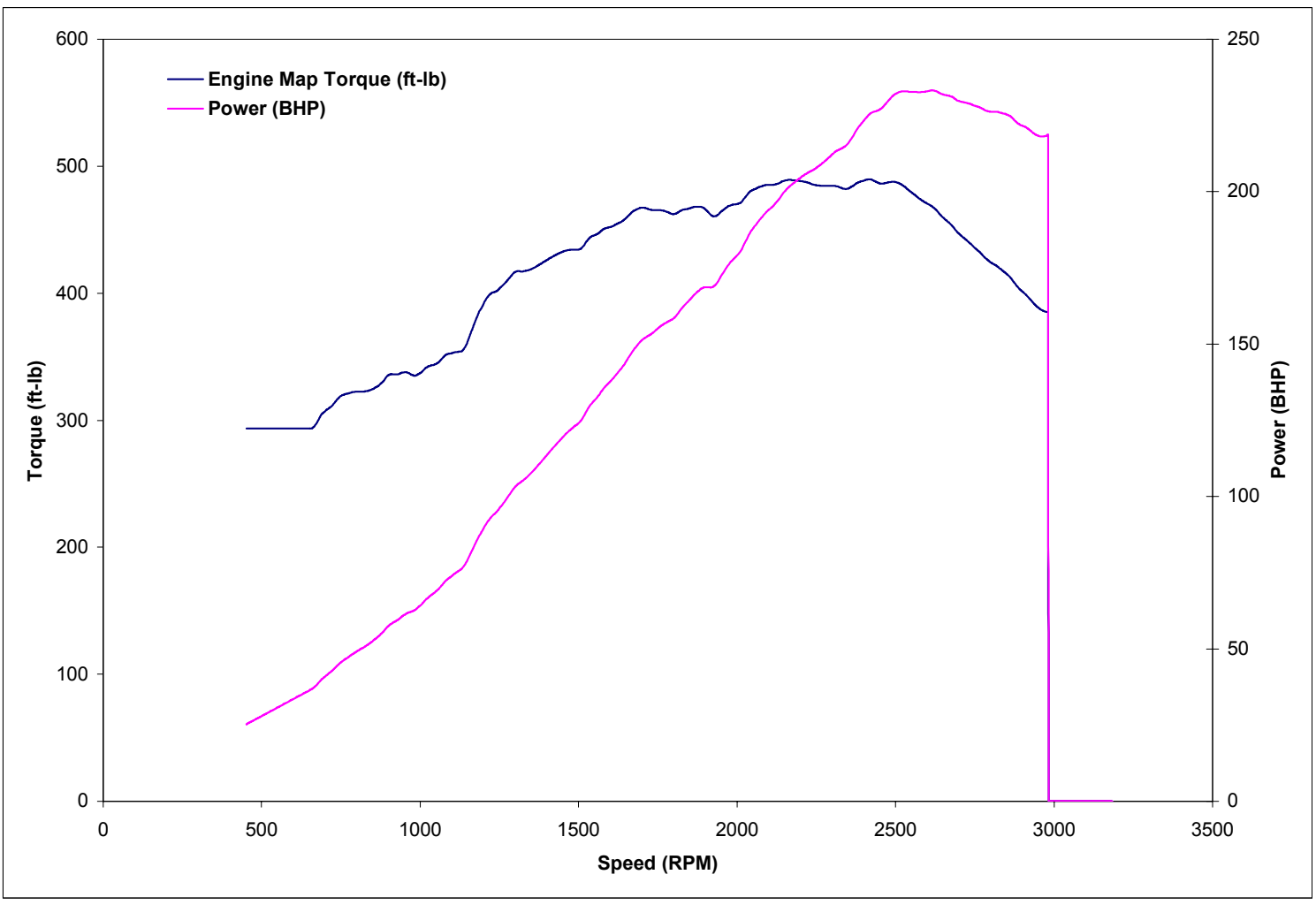

Figure 12 Engine map for the Navistar engine.

Table 9 Navistar engine specifications

\begin{tabular}{|l|l|}
\hline Engine Manufacturer & Navistar \\
\hline Engine Model & B 250 \\
\hline Displacement & $7.31 \mathrm{~L}$ \\
\hline Power Rating & $250 \mathrm{HP} @ 2300 \mathrm{RPM}$ \\
\hline Torque Rating & $505 \mathrm{lb}-\mathrm{ft} @ 1500 \mathrm{RPM}$ \\
\hline Bore X Stroke & 4.18 in X 4.11 in \\
\hline Configuration & V-8 \\
\hline Compression Ratio & $17.5: 1$ \\
\hline
\end{tabular}

\subsection{Test Cycles}

A brief description of each of the test cycles used in this study is given below.

\subsubsection{Steady State Test Cycles}

The steady state test cycles were conducted on the DDC Series 60 (Model year 2000) engine to measure $\mathrm{NO}_{\mathrm{x}}$ emissions. The test matrix for the steady-state tests was obtained by choosing grid points for different engine speeds and torques across the engine map. These steady state tests were conducted in modes with duration of 480 seconds each collecting $\mathrm{NO}_{\mathrm{x}}$ data during the final 60 seconds. Figure 13 represents the 
speed-time trace of one of the steady-state test cycles run on the DDC Series 60 engine. It has 4 steady-state modes each of 120 seconds duration.

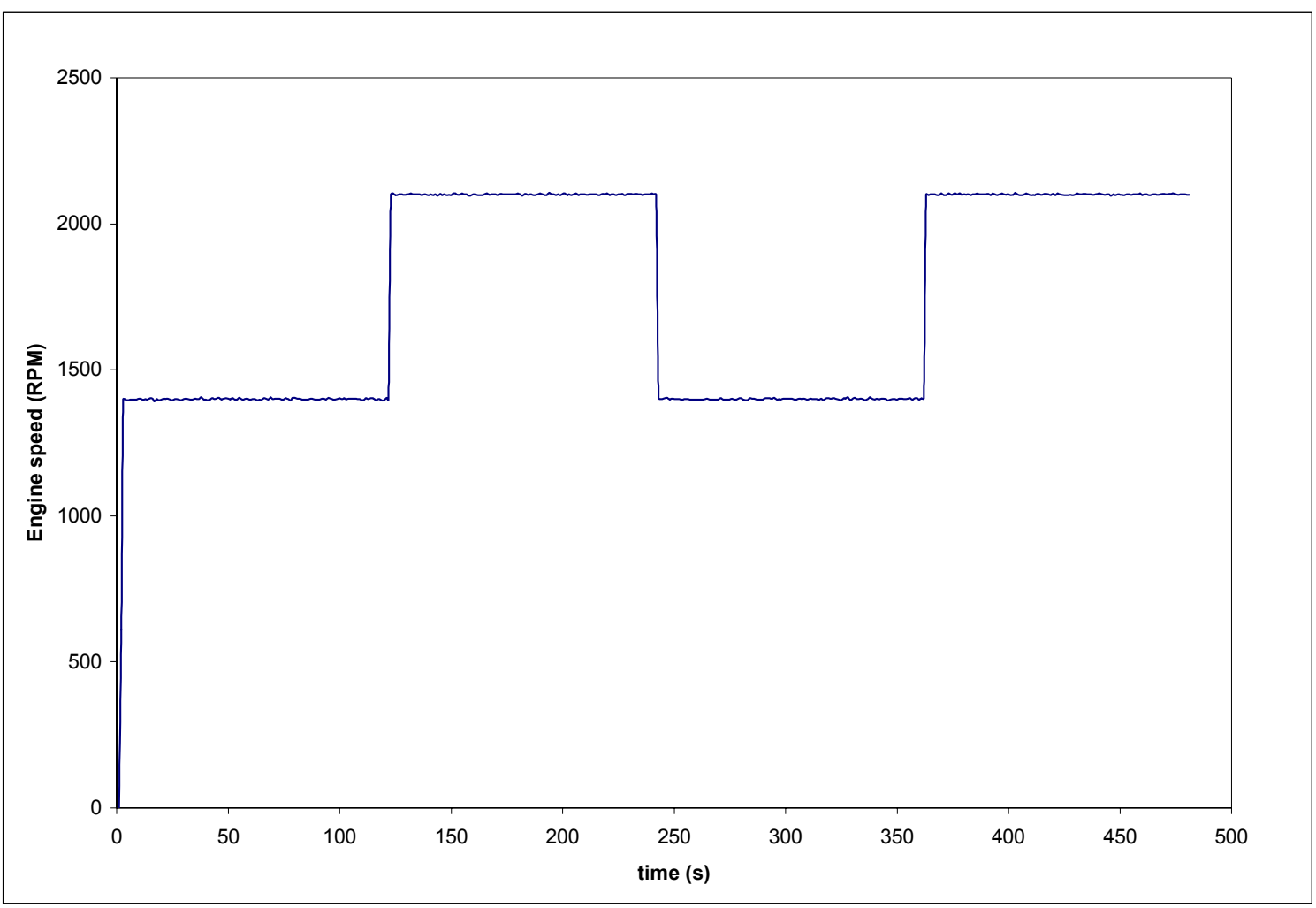

Figure 13 Speed - time trace of a steady-state test cycle run on the DDC Series 60 (Model Year 2000) engine.

\subsubsection{Trapezoidal Test Cycles}

The trapezoidal test cycles were conducted as part of a research project by Bane [15]. These cycles represented the effect of engine oscillations at various engine torques and at constant engine speed. These cycles were assumed as intermediate speed-torque conditions of transients between the steady-state test cycles and transient test cycles. During these cycles, the engine speed was held constant and the torque was oscillated from $20 \%$ of full power to full power in the form of a trapezoidal wave. A trapezoidal wave was chosen to slam the throttle shut during the oscillation as opposed to a gentle deceleration that was infered from a sine wave function. The cycles were repeated with all parameters unchanged with the exception of the frequency of the trapezoidal wave. These cycles were conducted on the DDC series 60 (Model year 2000) for which the 
engine speed was held at a constant 1500 RPM. The period lengths of the trapezoidal wave tests were 10-seconds, 4-seconds, 2-seconds, and 1-second respectively. The duration of each test was 378 seconds. $\mathrm{NO}_{\mathrm{x}}$ emissions from those tests were collected and used in this research. Figures 14, 15, 16 and 17 represent the torque and engine speed verses time plots for the 4 trapezoidal wave cycles. In order to present the oscillations clearly, only a portion of each cycle is shown.

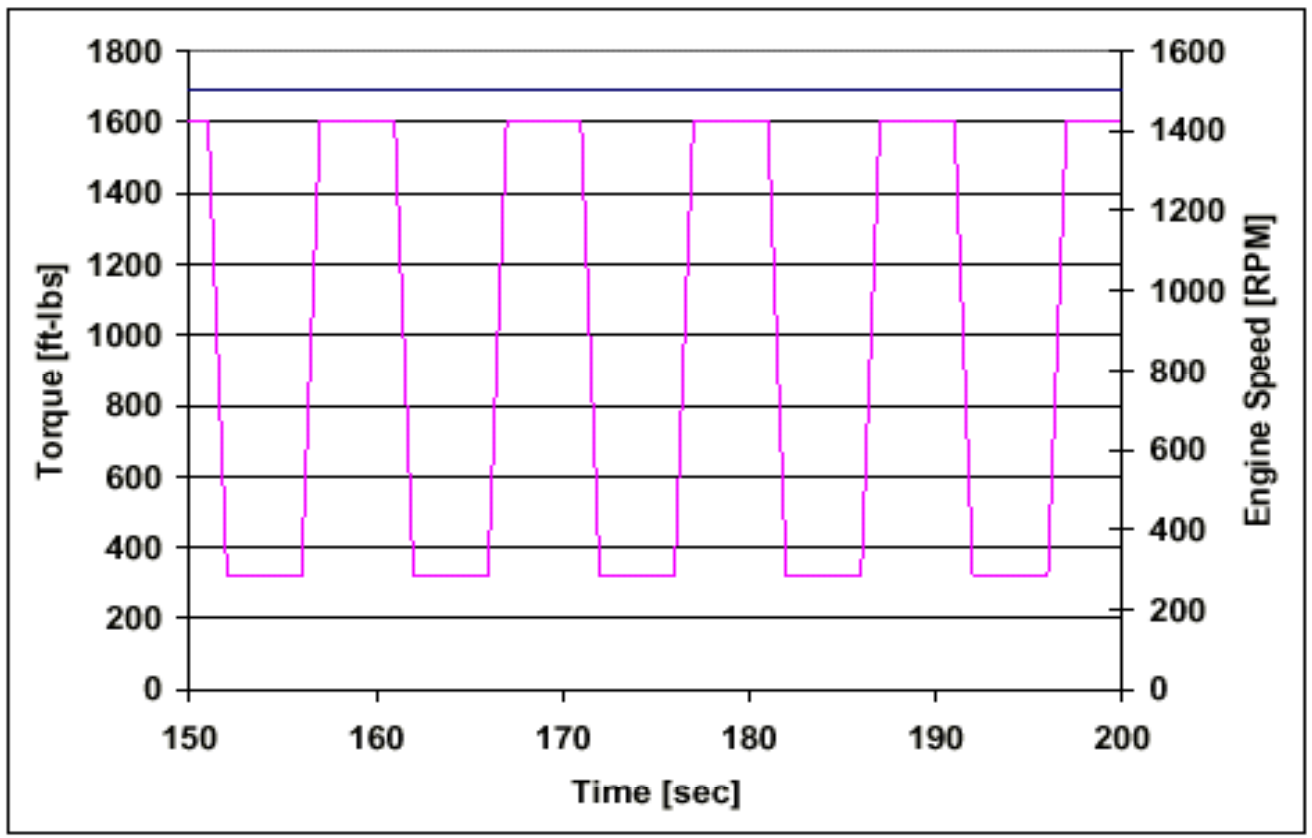

Figure 14 Variation of torque and engine speed with time for the 10-second period trapezoidal wave cycle on the DDC Series 60 engine. 


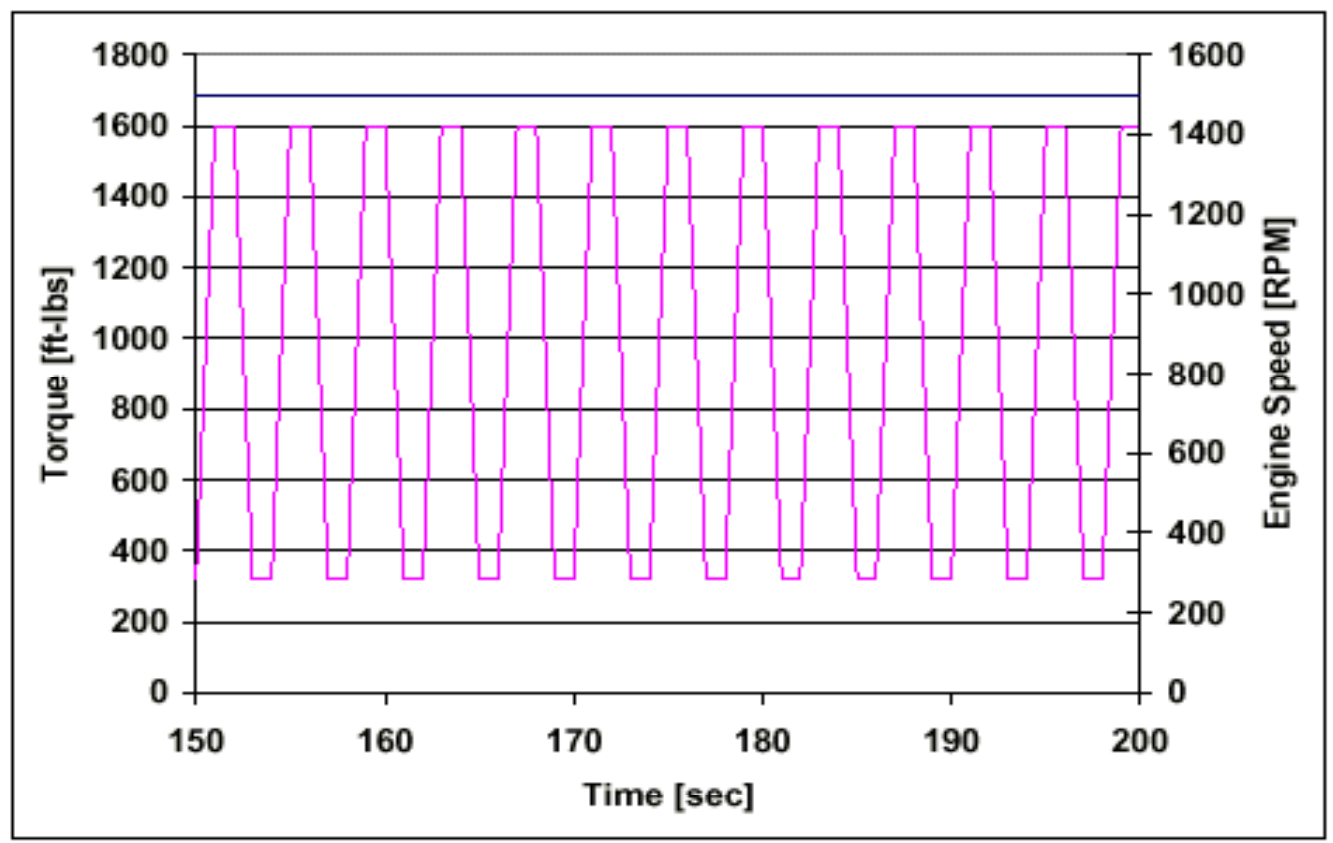

Figure 15 Torque and engine speed plotted with time for the 4-second period trapezoidal wave cycle for the DDC Series 60 engine.

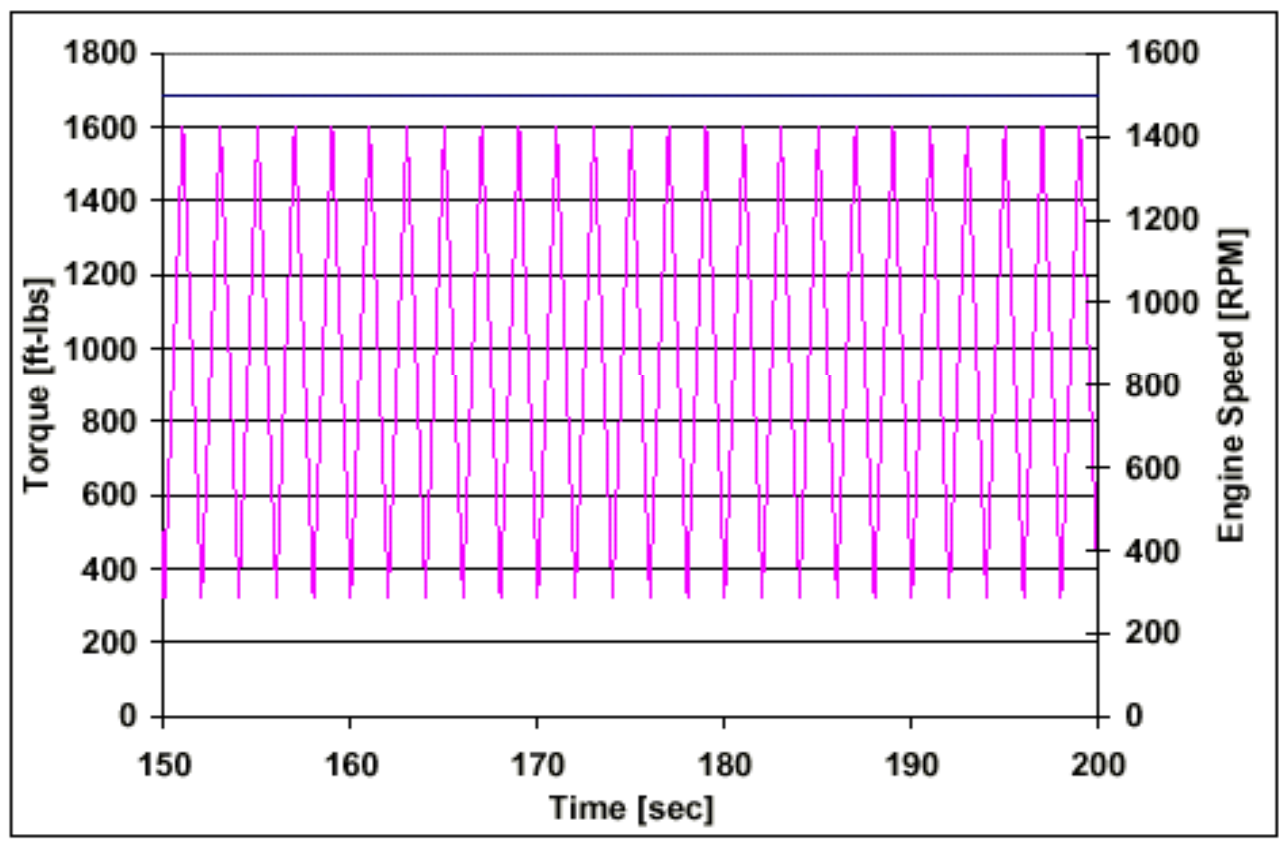

Figure 16 Torque and engine speed plotted against time for the 2-second period trapezoidal wave cycle for the DDC Series 60 engine. 


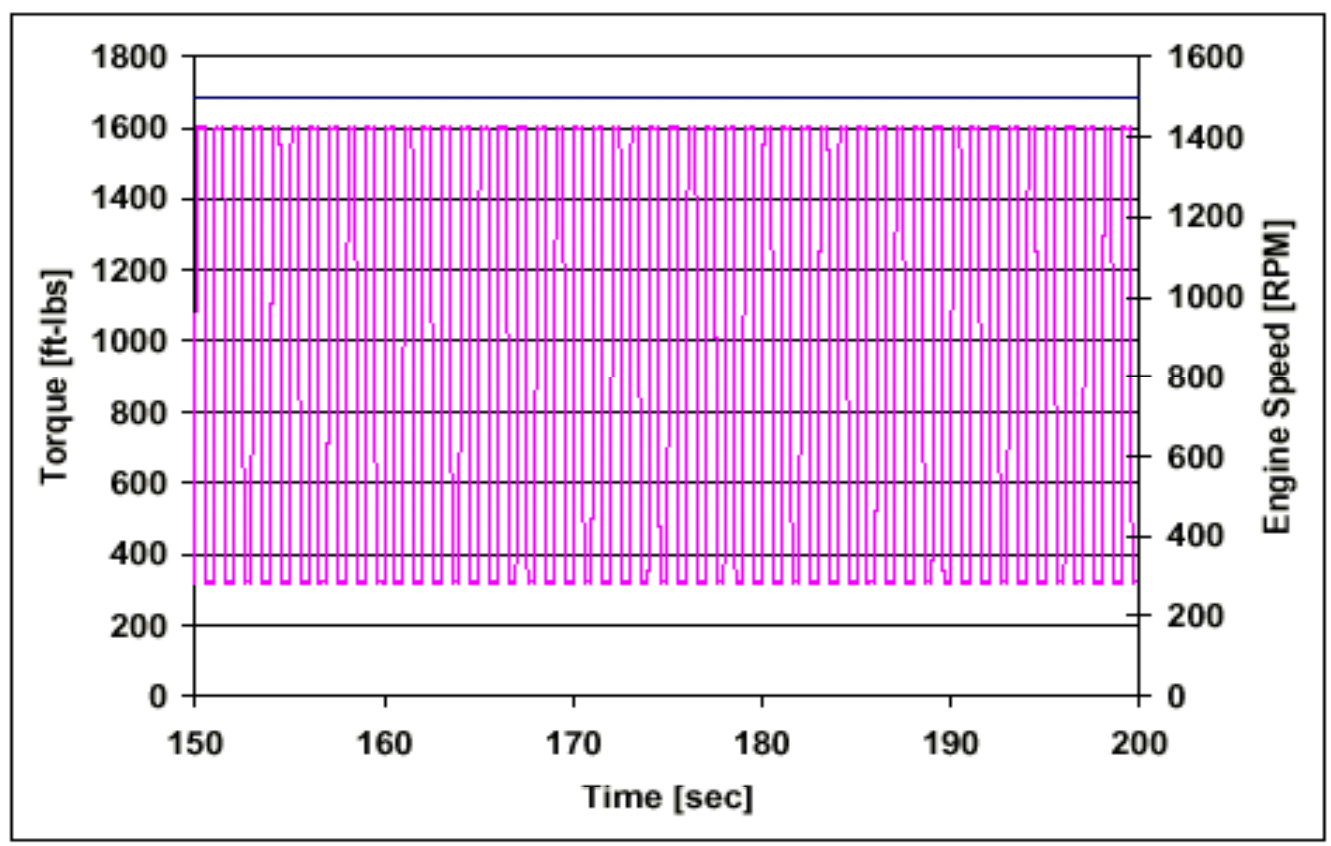

Figure 17 Torque and engine speed plotted against time for the 1-second period trapezoidal wave cycle for the DDC Series 60 engine.

\subsubsection{Transient Test Cycles}

After conducting steady-state tests and trapezoidal tests, standard transient tests were conducted to measure $\mathrm{NO}_{\mathrm{x}}$ emissions. Apart from the standard engine dynamometer test cycle FTP, other transient tests were also conducted. These engine test cycles were generated by converting the chassis dynamometer test cycles (used for emissions testing by the WVU Transportable Heavy-Duty Chassis Laboratory) into engine dynamometer test cycles. The input to these engine cycles was obtained from the data collected in a research project on multiple driving schedules to examine the emissions effect [20]. The test vehicle was a 1996 Peterbilt tractor truck powered by a 475-hp Caterpillar engine. The chassis dynamometer output displayed engine speed, axle horsepower, and axle torque and vehicle speed. The axle horsepower was converted to engine horsepower by dividing it by a factor of 0.85 to account for losses. This was an approximation. The engine horsepower was then converted to engine torque and was given as input to the engine dynamometer software at EERC. The transient chassis dynamometer test cycles were the City Suburban Heavy Vehicle Route (CSHVR), the European Transient Cycle 
(ETC), the Highway cycle and the WVU 5-Peak cycle. These cycles converted to the engine test cycles were referred to as CSHVR-E, ETC-E, Highway-E and the WVU 5Peak-E. Transient cycles conducted on the DDC Series 60, Model 2000 engine, are discussed next.

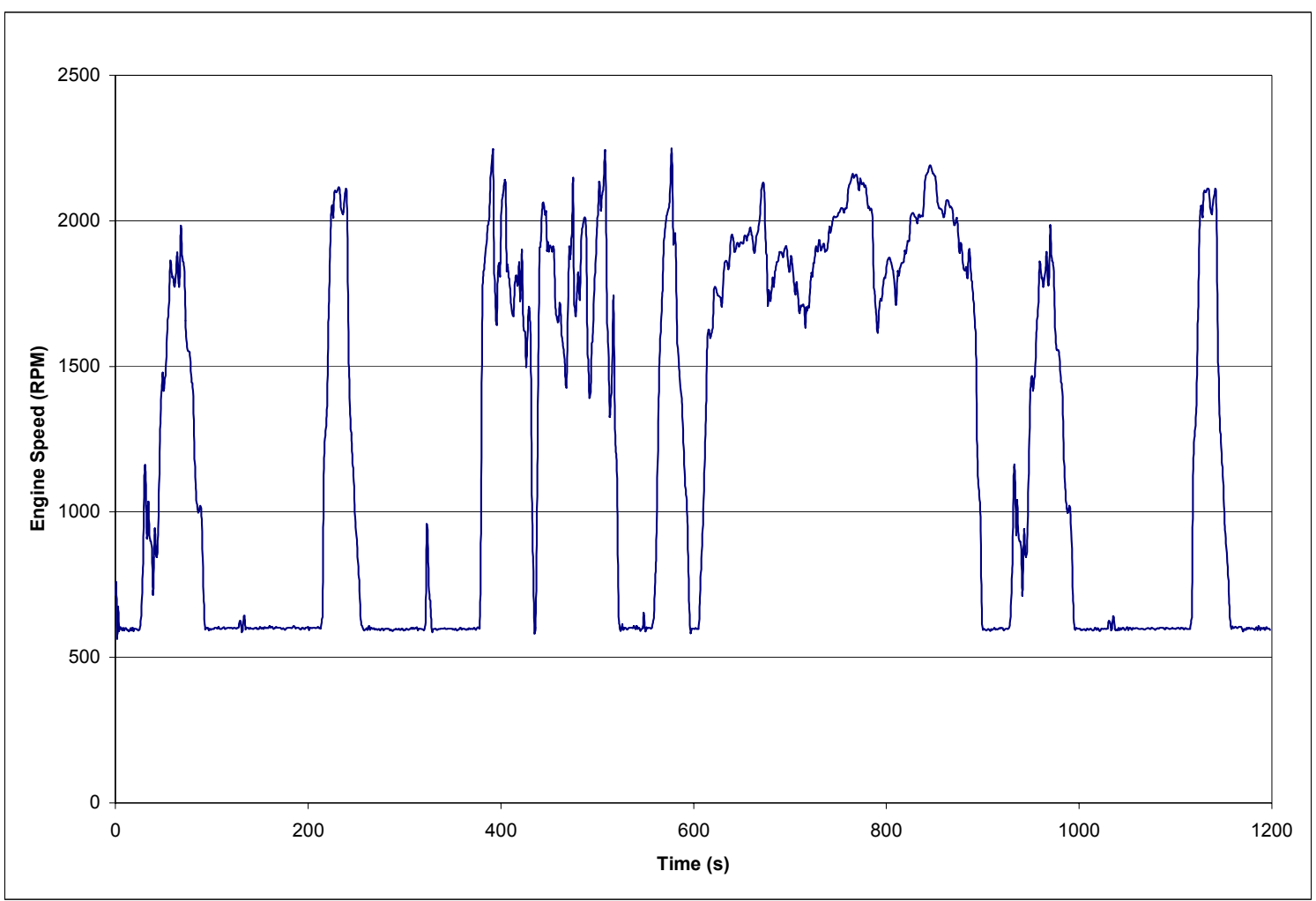

Figure 18 Speed-time trace of a FTP cycle run on the DDC Series 60 engine.

\subsubsection{Federal Transient Procedure (FTP) cycle:}

The FTP cycle is the standard test cycle used in the USA for emissions testing of heavy-duty on road diesel engines. This cycle was designed to represent freeway and non-freeway driving by heavy-duty vehicles in Los Angeles and New York City. It has three main segments called the NewYork Non Freeway (NYNF), Los Angeles Non Freeway (LANF) and Los Angeles Freeway (LAF). The FTP utilizes percentages of engine speed and engine torque from the engine map evaluated as input set points. Speed time trace of a FTP cycle run on the DDC Series 60 engine is as shown in Figure 18. For certification of engines, the FTP cycle is repeated three times. The first time is called the 
cold start, which is a simulation of overnight truck setting and operating early in the morning. The next two cycles are called hot start cycles where the engine is warmed up from the first cycle after a delay period of about 20 minutes. Duration of the FTP cycle is 1200 seconds.

\subsubsection{City-Suburban Heavy Vehicle Route (CSHVR - E):}

The CSHVR was developed from the City Suburban Cycle. The City Suburban Cycle generated by the researchers at West Virginia University, by collecting data on two heavy-duty tractors in order to create cycles based on daily operation [19]. The data were videotaped and further analyzed by breaking them into micro-trips representing four different driving modes. One of them is Suburban and the others are Freeway, City and Yard. Figure 19 displays the speed time trace of the CSHVR-E cycle run on the DDC Series 60 engine.

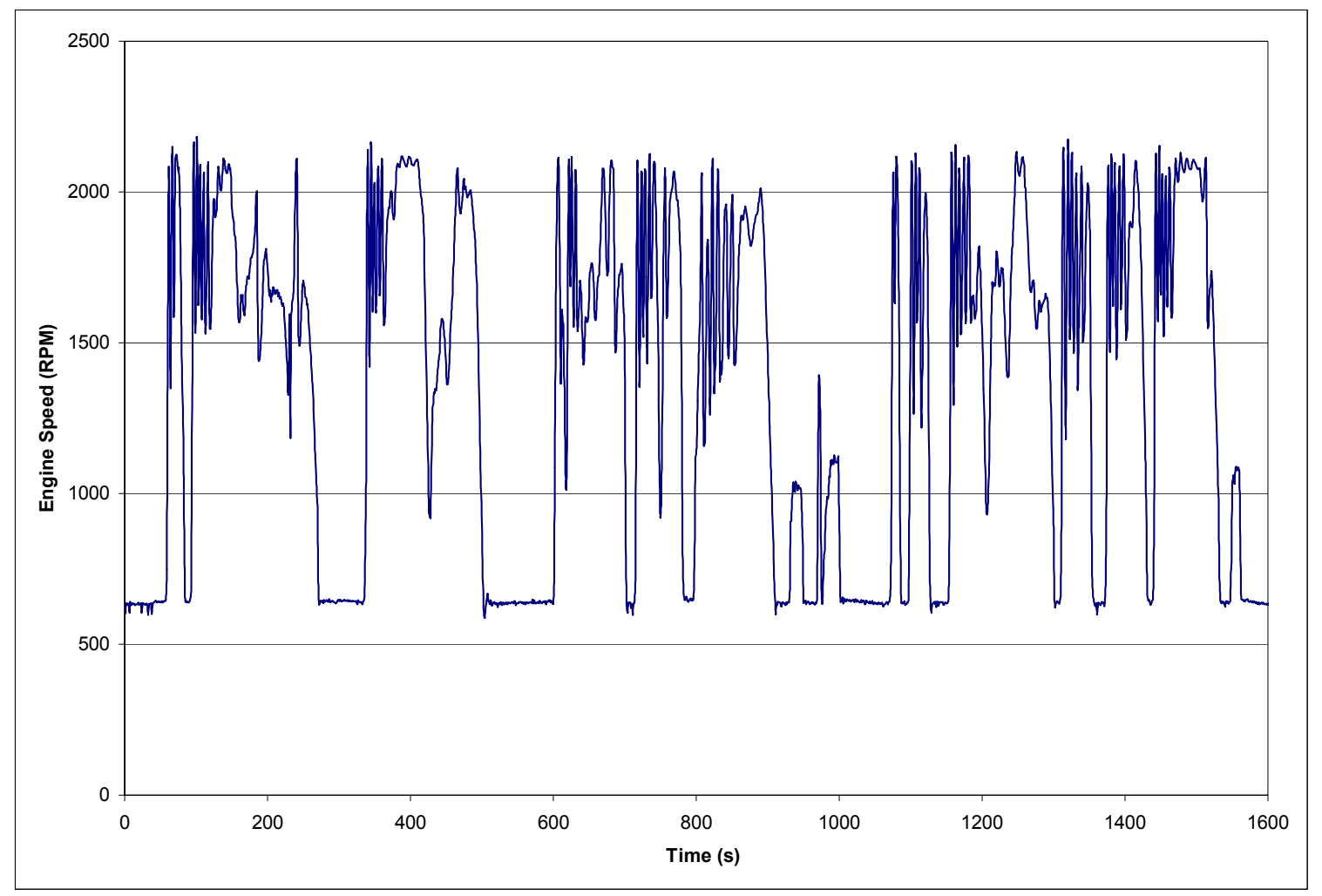

Figure 19 Speed-time trace of a CSHVR - E conducted on the DDC Series 60 engine. 
Duration of the CSHVR was 1700 seconds and the distance covered was 6.69 miles with an average velocity of $14.6 \mathrm{mph}$.

\subsubsection{European Transient Cycle (ETC - E):}

The ETC test cycle is the standard test cycle for emissions certification of heavyduty diesel engines in Europe. The ETC represents three different driving cycles. The first part represents city driving with a maximum speed of $32 \mathrm{mph}$ with frequent stops and starts and idling. The second part is rural driving with a steep acceleration segment. The average speed is about $45 \mathrm{mph}$. The third part is motorway driving with an average speed of $55 \mathrm{mph}$. Figure 20 represents the speed-time trace of a ETC-E cycle run on the DDC Series 60 engine. The duration of the cycle is 1800 seconds [20].

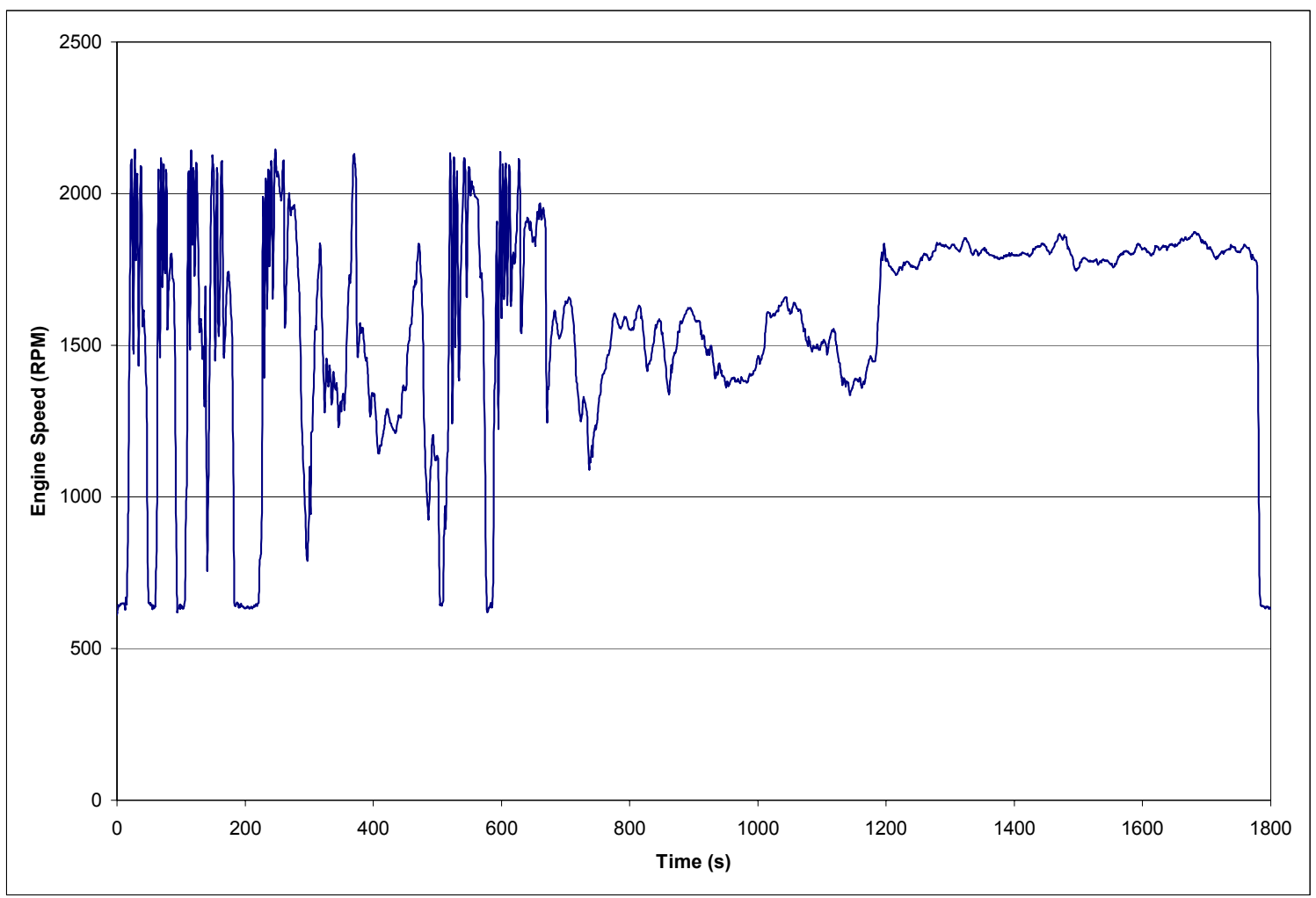

Figure 20 Speed-time trace of a ETC run on the DDC Series 60 engine. 


\subsubsection{Highway - E Cycle:}

The Highway cycle was also developed from the data obtained from the research by Clark et al. [18] on two tractors. It was based on the operation of the tractors to and from the city during its travel on 4-lane restricted highways [20]. Figure 21 represents the speed-time trace of Highway-E cycle operated on the DDC Series 60 engine. The duration of the cycle was 1640 seconds, distance traveled 15.51 miles and the average velocity was $34.05 \mathrm{mph}$.

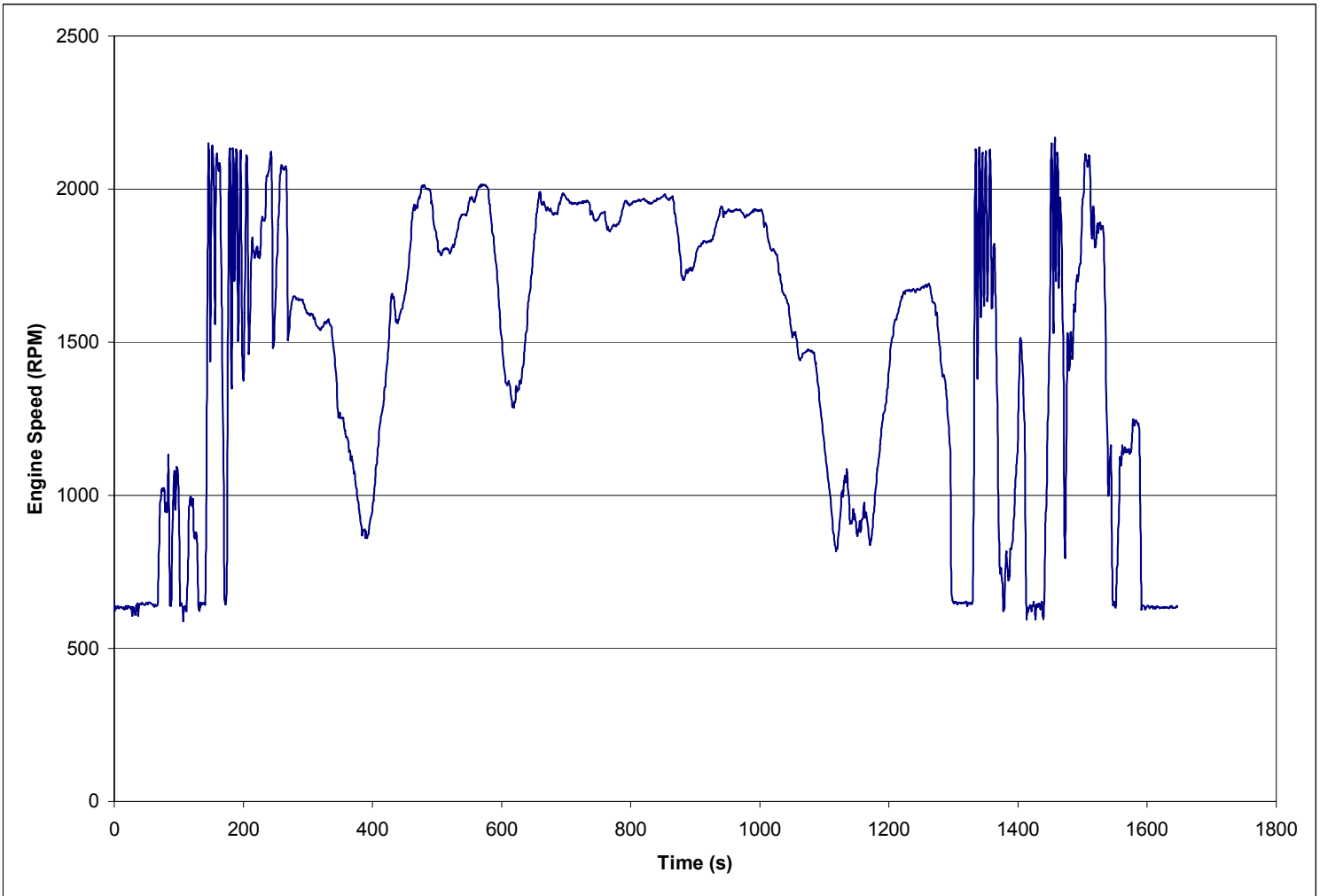

Figure 21 Speed-time trace of the Highway - E cycle operated on the DDC Series 60 engine.

\subsubsection{WVU 5 - Peak - E Cycle:}

The WVU 5-Peak cycle was generated for general truck testing on a chassis dynamometer. It was developed at the Vehicle and Emissions Testing Laboratory at West Virginia University [17]. Figure 22 represents the speed-time trace of the WVU 5 - Peak cycle run on the DDC Series 60 engine. The duration of the cycle was 900 seconds and 
the distance traveled was 5 miles. The 5 peaks are 20, 25, 30, 35 and $40 \mathrm{mph}$. The sudden oscillations of the engine speed at the beginning of each mode indicate the gear shifts of a manual transmission.

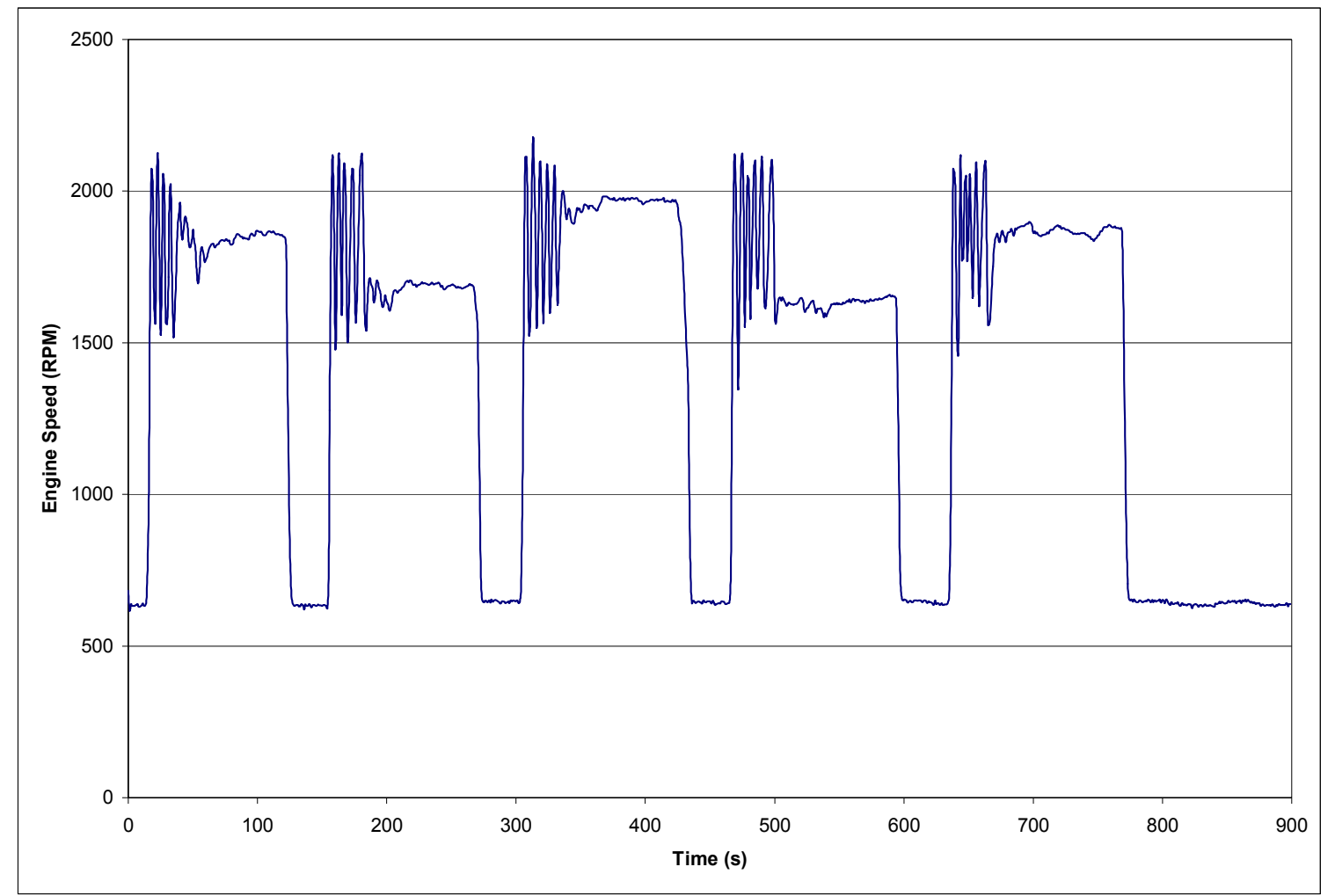

Figure 22 Speed-time trace of the WVU 5 - Peak cycle operated on the DDC Series 60 engine.

\subsection{Test Procedure}

This section gives the summary of all the tests performed for this thesis. Different test cycles were run on 6 heavy-duty diesel engines. A brief description of all the engines is given in Section 4.1. Most of the tests were performed on the DDC Series 60, Model year 2000 engine. Steady state, trapezoidal waves and transient tests were run on this engine. FTP tests were run on six different heavy-duty diesel engines. Each of the engines was placed in the test cell and was coupled to the DC dynamometer. Initially each engine was mapped and then the test cycles were developed based on the engine maps. Then these tests were run on the engines and the exhaust emissions were made to pass through the analyzers for emissions measurement. The fast $\mathrm{NO}_{\mathrm{x}}$ analyzer mostly 
sampled raw exhaust except for a few tests where it was used to measure the dilute exhaust. For raw sampling, the sample probe was hooked up into the exhaust manifold at a distance of about $1 \mathrm{ft}$ from the turbocharger and for dilute sampling, the fast $\mathrm{NO}_{\mathrm{x}}$ probe was inserted into the dilution tunnel in the plane from which slow $\mathrm{NO}_{\mathrm{x}}$ data was sampled. The fast $\mathrm{NO}_{\mathrm{x}}$ analyzer measured only $\mathrm{NO}$ emissions (bulk of the engine out emissions is called $\mathrm{NO}$ ) whereas the slow $\mathrm{NO}_{\mathrm{x}}$ analyzer measured both $\mathrm{NO}$ and $\mathrm{NO}_{2} . \mathrm{NO}_{\mathrm{x}}$ mostly consist of $\mathrm{NO}$ and $\mathrm{NO}_{2}$. In this thesis, the emissions obtained from both the analyzers are referred to as $\mathrm{NO}_{\mathrm{x}}$ emissions.

\subsection{Instantaneous $\mathrm{NO}_{\mathrm{x}}$ Emissions Calculations}

Test data obtained from the data acquisition software was further reduced using the methods given in CFR 40 Part 86 and the emissions were obtained in the form of test average, integrated and instantaneous mass basis $(\mathrm{g} / \mathrm{s})$ for Rosemount slow $\mathrm{NO}_{\mathrm{x}}$ analyzer. However the fast $\mathrm{NO}_{\mathrm{x}}$ data was obtained as a concentration (PPM) and was converted into mass flow rate $(\mathrm{g} / \mathrm{s})$ by the following equations.

For raw emissions,

Fast $N O_{x}($ mass rate $)=\frac{K_{H} * N O_{x}(P P M)_{i} * \rho_{N O_{x}} * V_{i}}{10^{6}}$ Equation 9

Where Fast $\mathrm{NO}_{\mathrm{x}}$ (mass rate) is the fast $\mathrm{NO}_{\mathrm{x}}$ emissions value in $\mathrm{g} / \mathrm{s}, \mathrm{NO}_{\mathrm{x}}(\mathrm{PPM})_{\mathrm{i}}$ is the instantaneous concentration of fast $\mathrm{NO}_{\mathrm{x}}$ exhaust sample in parts per million, $\mathrm{K}_{\mathrm{H}}$ is the humidity correction factor, $\rho_{\mathrm{NO}}$ is the density of $\mathrm{NO}_{\mathrm{x}}\left(\mathrm{kg} / \mathrm{m}^{3}\right)$ assuming it to be in the form of $\mathrm{NO}_{2}$ at standard conditions of $20{ }^{\circ} \mathrm{C}$ and $760 \mathrm{~mm} \mathrm{Hg}$ pressure and $\mathrm{V}_{\mathrm{i}}$ is the volume flow rate of the intake air or exhaust in $\mathrm{m}^{3} / \mathrm{s}$. Both intake air flow rate and exhaust flow rate were used for calculating the raw fast $\mathrm{NO}_{\mathrm{x}}$ emissions. Results are discussed in detail in Chapter 5. 
For Dilute emissions,

Fast $N O_{x}($ mass rate $)=\frac{K_{H} * N O_{x}(P P M)_{i} * \rho_{N O_{x}} * V_{i}}{10^{6}}-\frac{K_{H} * N O(P P M)_{b} *\left(1-\frac{1}{D F}\right) * \rho_{N O_{x}} * V_{b}}{t}$

Where subscript " $i$ " denotes the instantaneous value recorded during the test, "b" denotes the background bag value and " $\mathrm{t}$ " denotes the duration of the test in seconds, and DF - the dilution factor (ratio of dilute air to exhaust). 


\section{Chapter 5 Results and Discussion}

In this chapter the results obtained from tests performed on six heavy-duty diesel engines were compared and analyzed based on parameters like engine type and test type. Fast $\mathrm{NO}_{\mathrm{x}}$ data were used to form inventory tables. Power based fast $\mathrm{NO}_{\mathrm{x}}$ emissions models were developed to predict instantaneous $\mathrm{NO}_{\mathrm{x}}$ emissions.

\subsection{Tests on DDC Series 60, Model Year 2000}

Steady state, trapezoidal and transient engine tests were conducted on the DDC series 60 engine and $\mathrm{NO}_{\mathrm{x}}$ emissions were measured using both the slow and fast $\mathrm{NO}_{\mathrm{x}}$ analyzers. Results obtained from the tests are discussed.

\subsubsection{Steady State Test Results}

Set points for the steady state test performed on the DDC Series 60 engine were obtained from the engine map discussed in Section 4.1.1. Figure 23 shows the relation between raw fast $\mathrm{NO}_{\mathrm{x}}$, dilute slow $\mathrm{NO}_{\mathrm{x}}\left(\right.$ Rosemount $\left.\mathrm{NO}_{\mathrm{x}}\right)$ and time. From the figure it is evident that the shape of the emissions signal from the analyzers is almost similar but their readings differed by about $20-30 \%$. Steady state test cycle average emissions on a mass basis for the slow $\mathrm{NO}_{\mathrm{x}}$ and fast $\mathrm{NO}$ were found to be $0.23 \mathrm{~g} / \mathrm{s}$ and $0.22 \mathrm{~g} / \mathrm{s}$ respectively. Cycle integrated values measured were $112 \mathrm{~g} / \mathrm{s}$ and $105 \mathrm{~g} / \mathrm{s}$. This difference in the emissions from the two analyzers was due to the $\mathrm{NO}_{2}$ component of $\mathrm{NO}_{\mathrm{x}}$, which is typically about 5-8\%. In general, for diesel engines the $\mathrm{NO}_{2}$ component was known to be $10-20 \%$ of the total $\mathrm{NO}_{x}[35]$. Also the analyzer dynamics (due to the sample flow) had an effect on the measured values. Fast $\mathrm{NO}_{\mathrm{x}}$ analyzer measured only $\mathrm{NO}$ whereas the slow analyzer measured $\mathrm{NO}_{\mathrm{x}}$. 


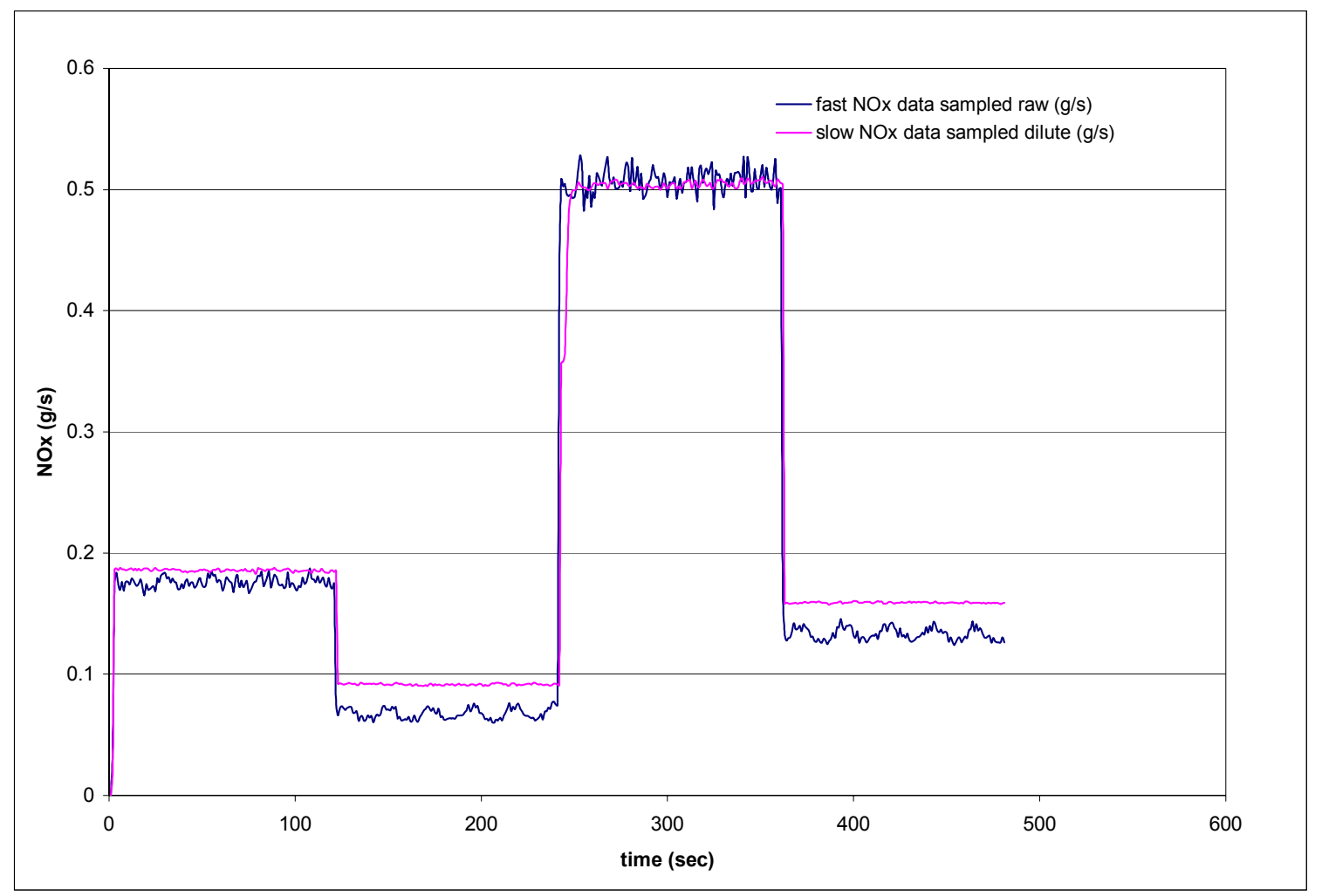

Figure 23 Variation of $\mathrm{NO}_{\mathrm{x}}$ emissions with time for a steady state test cycle run on the DDC Series 60 engine.

\subsubsection{Trapezoidal test results}

\subsubsection{10-Second Period Oscillation}

Trapezoidal test cycles are described in detail in Section 4.2.2. This test was performed on the DDC Series 60 engine wherein the input command oscillated in a trapezoidal wave configuration with a period of 10 -seconds from $20 \%$ full power to $100 \%$ full power at a constant engine speed of 1500 RPM. Actual work done during the cycle was $21.97 \mathrm{bhp}-\mathrm{hr}$ and the brake specific fuel consumed was $0.367 \mathrm{lb} . / \mathrm{bhp}-\mathrm{hr}$. Figure 24 shows $\mathrm{NO}_{\mathrm{x}}$ measurements obtained from the two analyzers (slow and fast $\mathrm{NO}_{\mathrm{x}}$ analyzers) for the trapezoidal wave with a 10 second time period of oscillation. From the figure it is evident that the fast $\mathrm{NO}_{\mathrm{x}}$ analyzer captures the signal faster than the slow analyzer and thus the two waves have a time lag. 


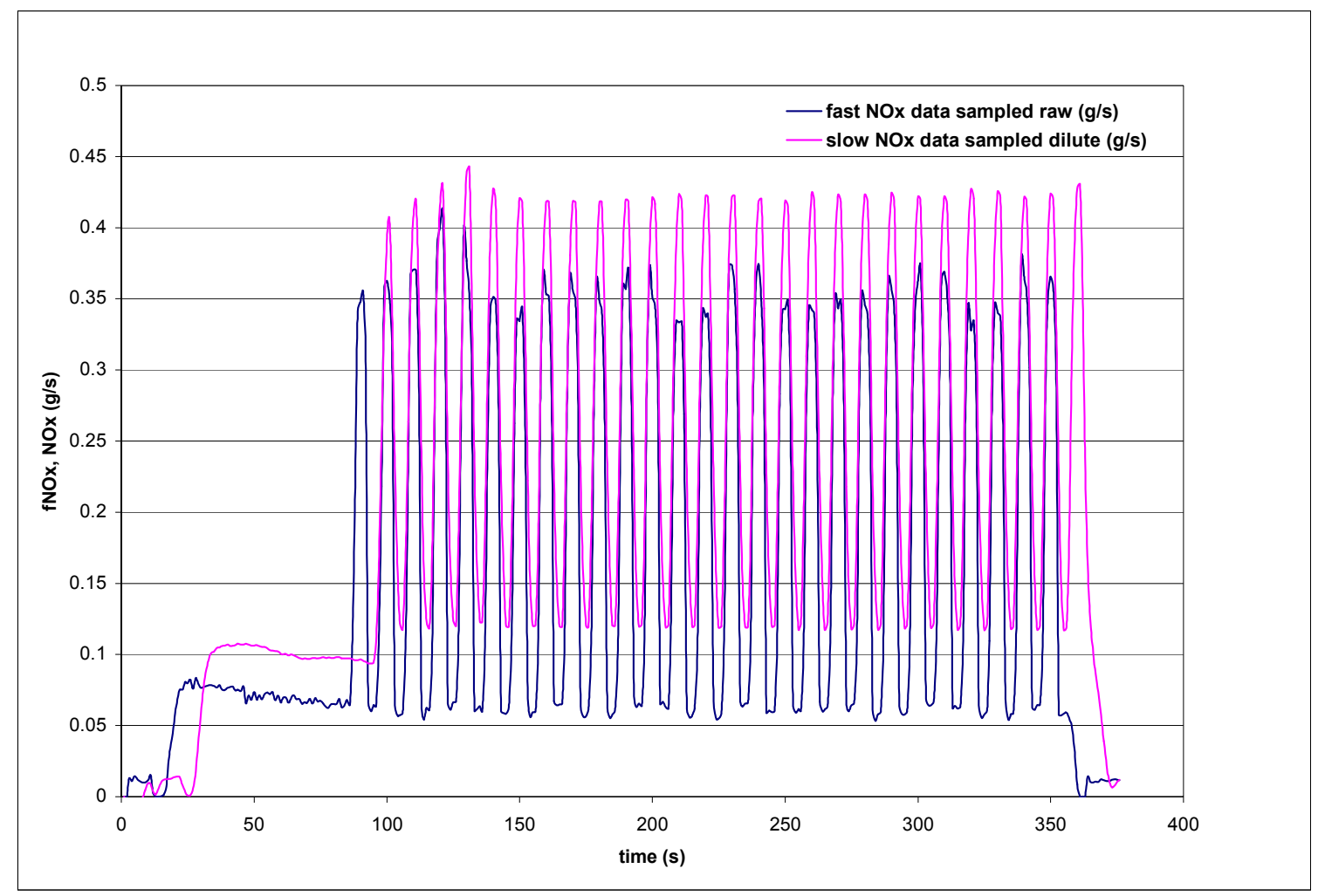

Figure 24 Variation of $\mathrm{NO}_{\mathrm{x}}$ emissions from the two analyzers for the trapezoidal wave with 10-second period of oscillation run on the DDC Series 60 engine.

In order to avoid this and make the comparison easier, the slow $\mathrm{NO}_{\mathrm{x}}$ analyzer's signal was shifted for 10 seconds. The time shift for the waves was determined by a peak to peak correlation between the two waves. Time shifted $\mathrm{NO}_{\mathrm{x}}$ emissions variation with time are as shown in Figure 25. Brake specific $\mathrm{NO}_{\mathrm{x}}$ emissions obtained from this test were $3.609 \mathrm{~g} / \mathrm{bhp}-\mathrm{hr}$ and the cycle average emissions were $0.217 \mathrm{~g} / \mathrm{s}$ for slow $\mathrm{NO}_{\mathrm{x}}$ data and $0.156 \mathrm{~g} / \mathrm{s}$ for the fast $\mathrm{NO}_{\mathrm{x}}$ data. A part of this difference was due to the $\mathrm{NO}_{2}$ present in the slow $\mathrm{NO}_{\mathrm{x}}$ data and the rest could be because the fast $\mathrm{NO}_{\mathrm{x}}$ emissions were not accounted for humidity. The percentage difference in the $\mathrm{NO}_{\mathrm{x}}$ values obtained from both the analyzers was reduced by about $10 \%$ after the humidity correction for the fast $\mathrm{NO}_{\mathrm{x}}$ data. 


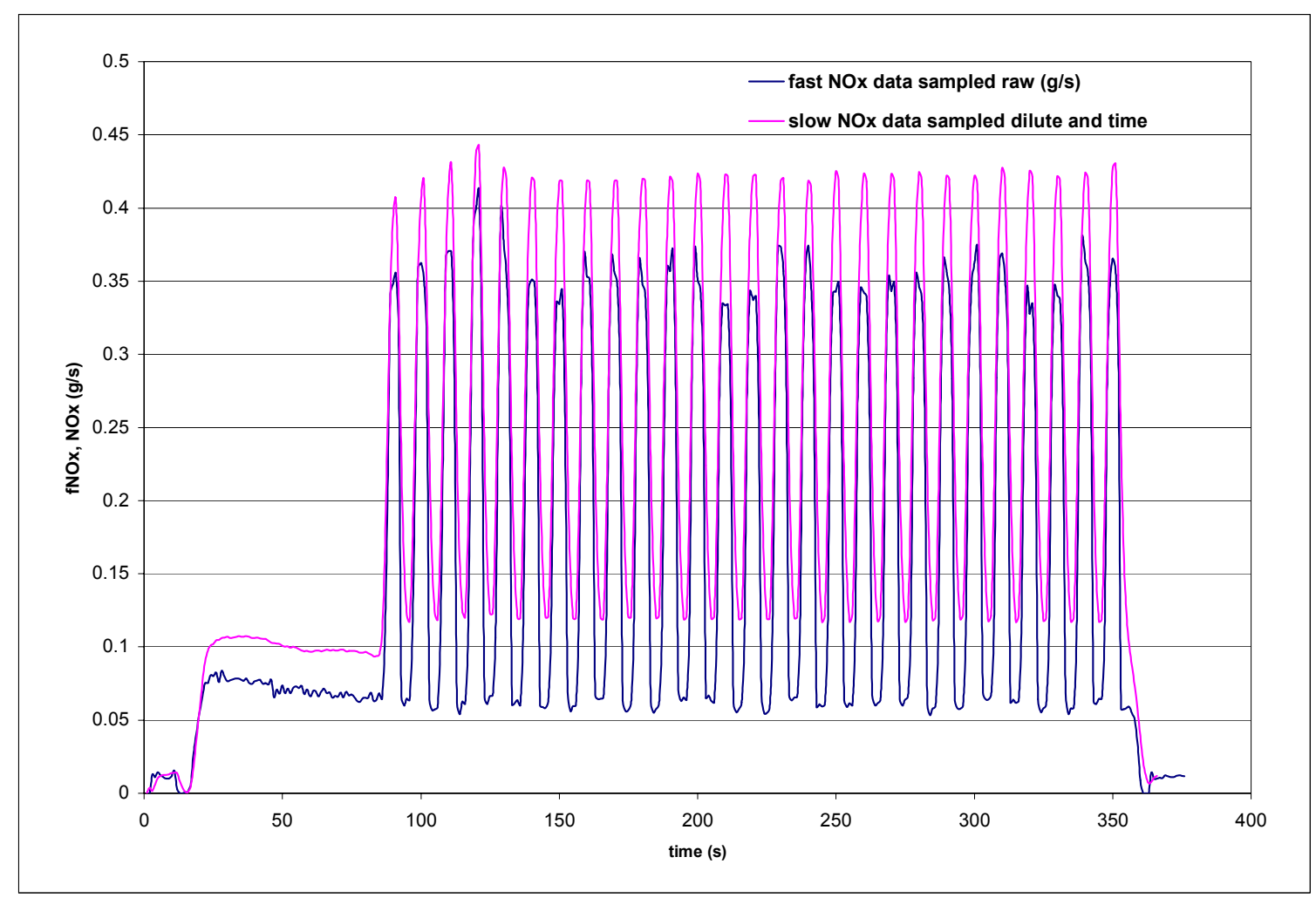

Figure 25 Time shifted slow $\mathrm{NO}_{\mathrm{x}}$ and fast $\mathrm{NO}_{\mathrm{x}}$ plotted against time for the trapezoidal wave with 10-second period of oscillation on the DDC Series 60 engine.

Figure 26 shows variation of power and $\mathrm{NO}_{\mathrm{x}}$ emissions with time. From the figure, it is evident that $\mathrm{NO}_{\mathrm{x}}$ emissions behaved in harmony with power since the shapes of the curves are similar for both $\mathrm{NO}_{\mathrm{x}}$ emissions and power. It is also seen that the signals for fast $\mathrm{NO}_{\mathrm{x}}$ and power do not need a time shift. Both the signals are captured at almost the same time. This shows the instantaneous nature of the fast $\mathrm{NO}_{\mathrm{x}}$ analyzer. 


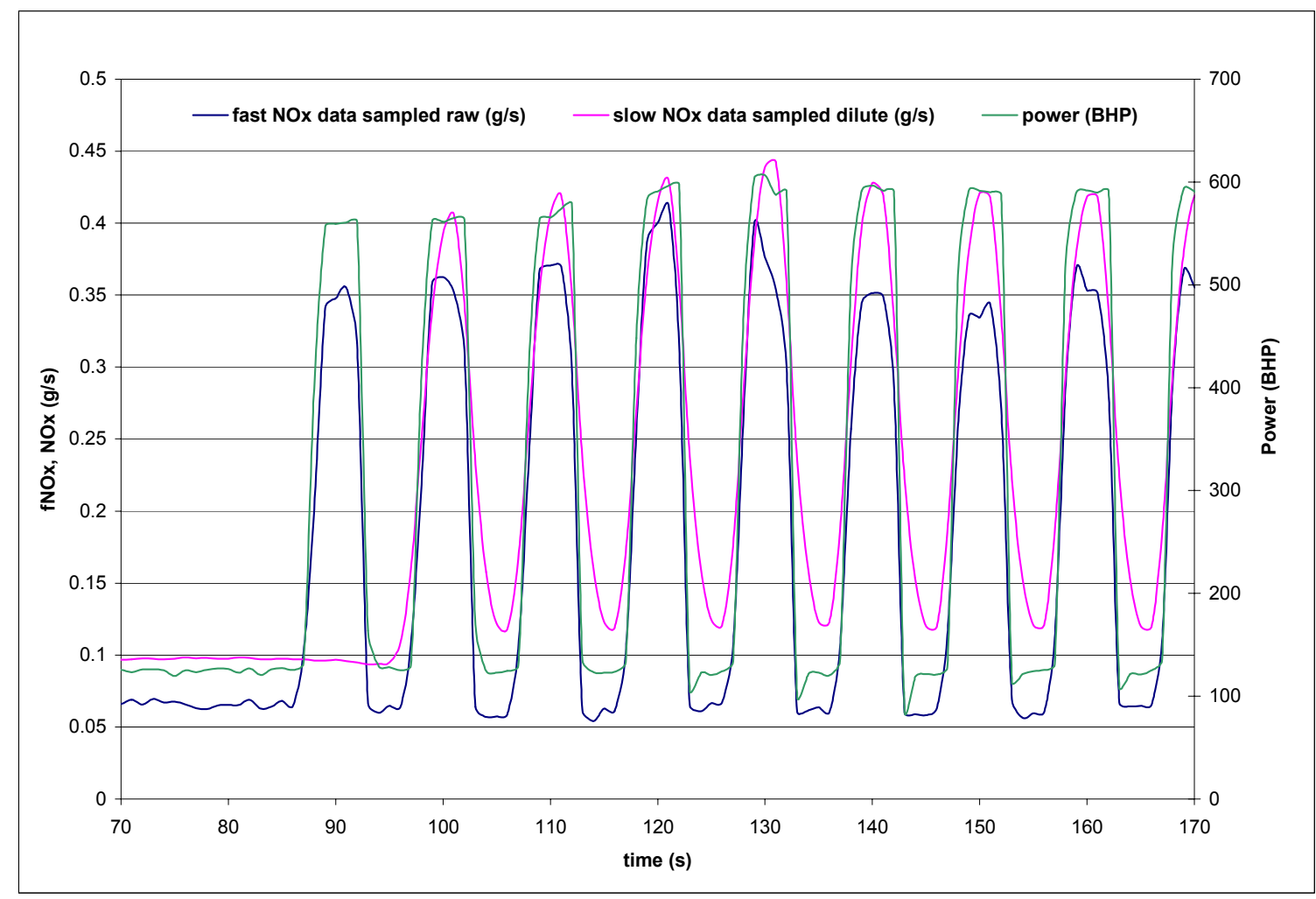

Figure 26 Power and $\mathrm{NO}_{\mathrm{x}}$ emissions plotted against time for the trapezoidal wave with 10-second period of oscillation on the DDC Series 60 engine.

From Figure 26, dependence of power on fast $\mathrm{NO}_{\mathrm{x}}$ emissions is known. Hence graphs are plotted between emissions from both the $\mathrm{NO}_{\mathrm{x}}$ analyzers and power. Figure 27 shows the relation between power and slow $\mathrm{NO}_{\mathrm{x}}$ and Figure 28 shows the same with fast $\mathrm{NO}_{\mathrm{x}}$. From the two figures, it is evident that fast $\mathrm{NO}_{\mathrm{x}}$ has a better correlation $\left(\mathrm{R}^{2}\right.$ value of $0.9691)$ with power than the slow $\mathrm{NO}_{\mathrm{x}}\left(\mathrm{R}^{2}\right.$ value of 0.8896$)$. Also it is noticed from Figure 27 that when the power is oscillated between $20 \%$ full power to full power, the slow $\mathrm{NO}_{\mathrm{x}}$ is a straight line (at about $100 \mathrm{BHP}$ power) whereas from Figure 28, it is a cluster of points. This is due to the effect of dispersion in the measured emissions from both the analyzers. The slow $\mathrm{NO}_{\mathrm{x}}$ analyzer captures the data in a more dispersed form and so gives a range of values for the same power leading to a straight line whereas the fast $\mathrm{NO}_{\mathrm{x}}$ analyzer captures instantaneous data and hence gives values as a cluster of points in the Figure 28. 


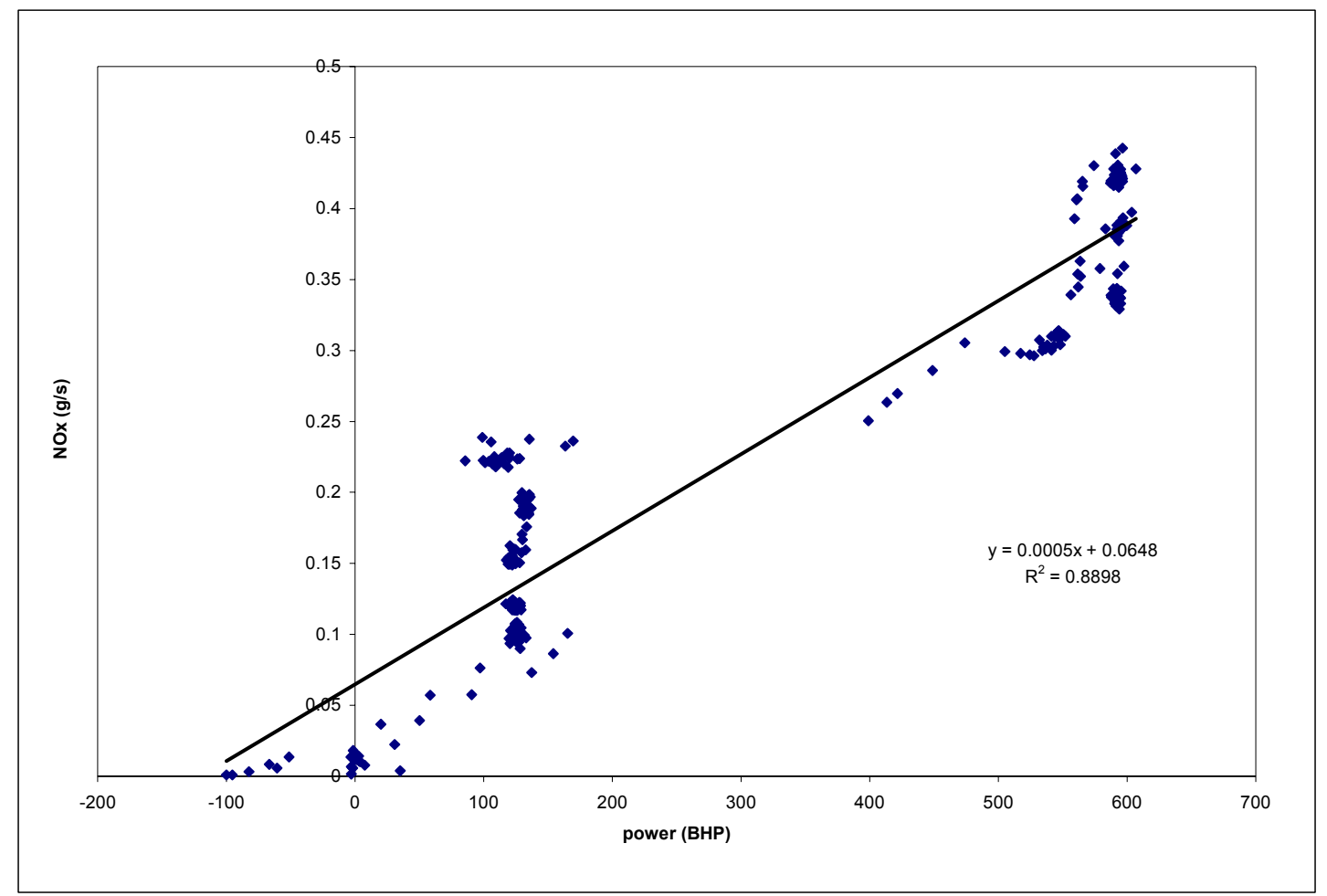

Figure 27 Slow $\mathrm{NO}_{\mathrm{x}}$ plotted against power for the 10 -second trapezoidal wave.

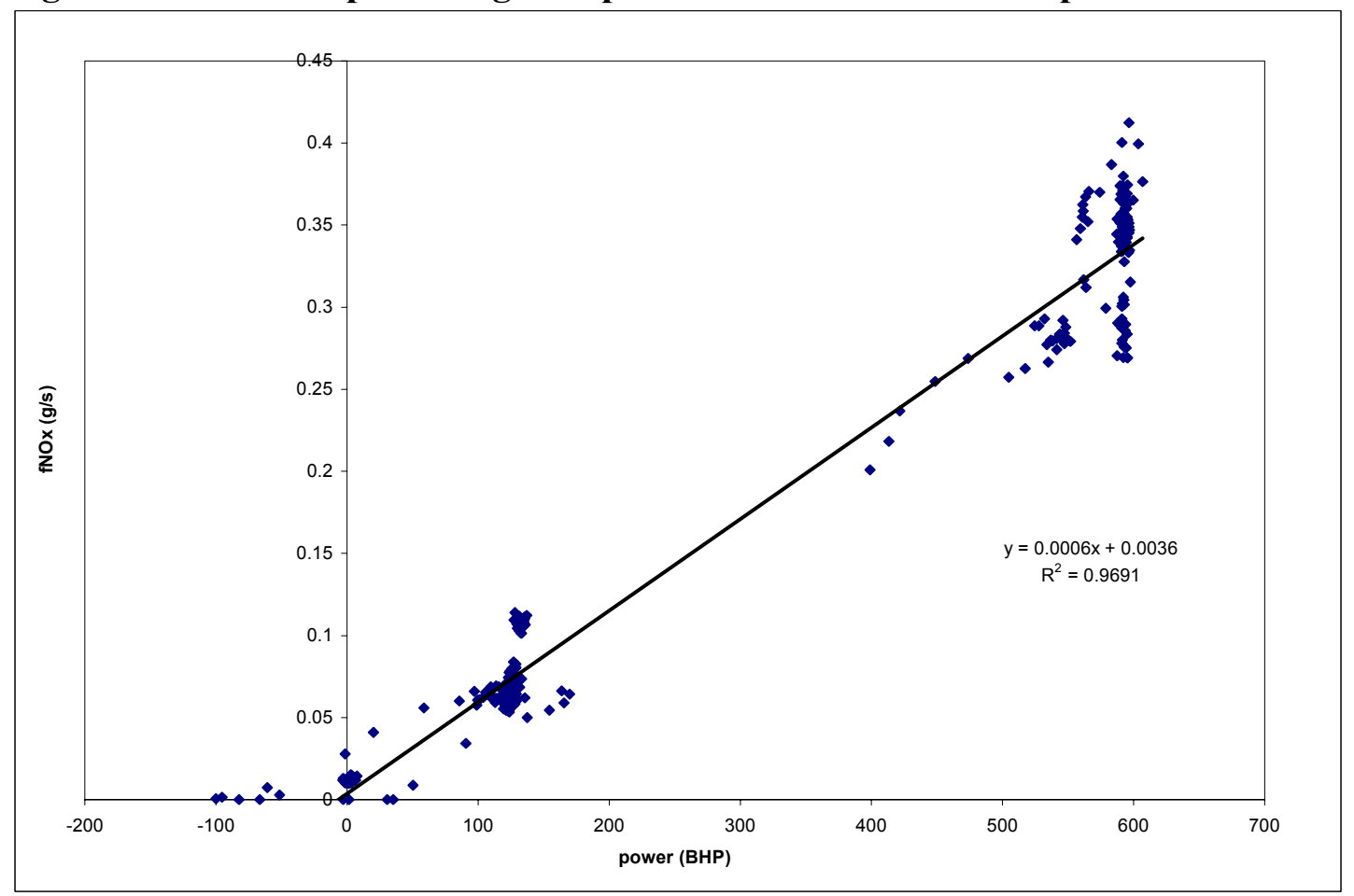

Figure 28 Fast $\mathrm{NO}_{\mathrm{x}}$ plotted against power for the 10-second trapezoidal wave.

\subsubsection{4-Second Period Oscillation}

Similar to the 10 -sec trapezoidal oscillations, the 4-sec oscillation tests were conducted on the DDC Series 60 engine and results were plotted and analyzed. Figure 29 shows the emissions variation with time plot for both the analyzers without anytime shift 
and Figure 30 shows the same with a 10-sec time shift. Work done during the trapezoidal test cycle with 4 -sec period of oscillations was $22.61 \mathrm{bhp}-\mathrm{hr}$ and the break specific fuel consumed was $0.374 \mathrm{lb}$./bhp-hr. Brake specific $\mathrm{NO}_{\mathrm{x}}$ emissions from the slow $\mathrm{NO}_{\mathrm{x}}$ analyzer for continuous sampling were $3.389 \mathrm{~g} / \mathrm{bhp}-\mathrm{hr}$. Cycle average values for the fast $\mathrm{NO}_{\mathrm{x}}$ and slow $\mathrm{NO}_{\mathrm{x}}$ were $0.147 \mathrm{~g} / \mathrm{s}$ and $0.203 \mathrm{~g} / \mathrm{s}$ respectively.

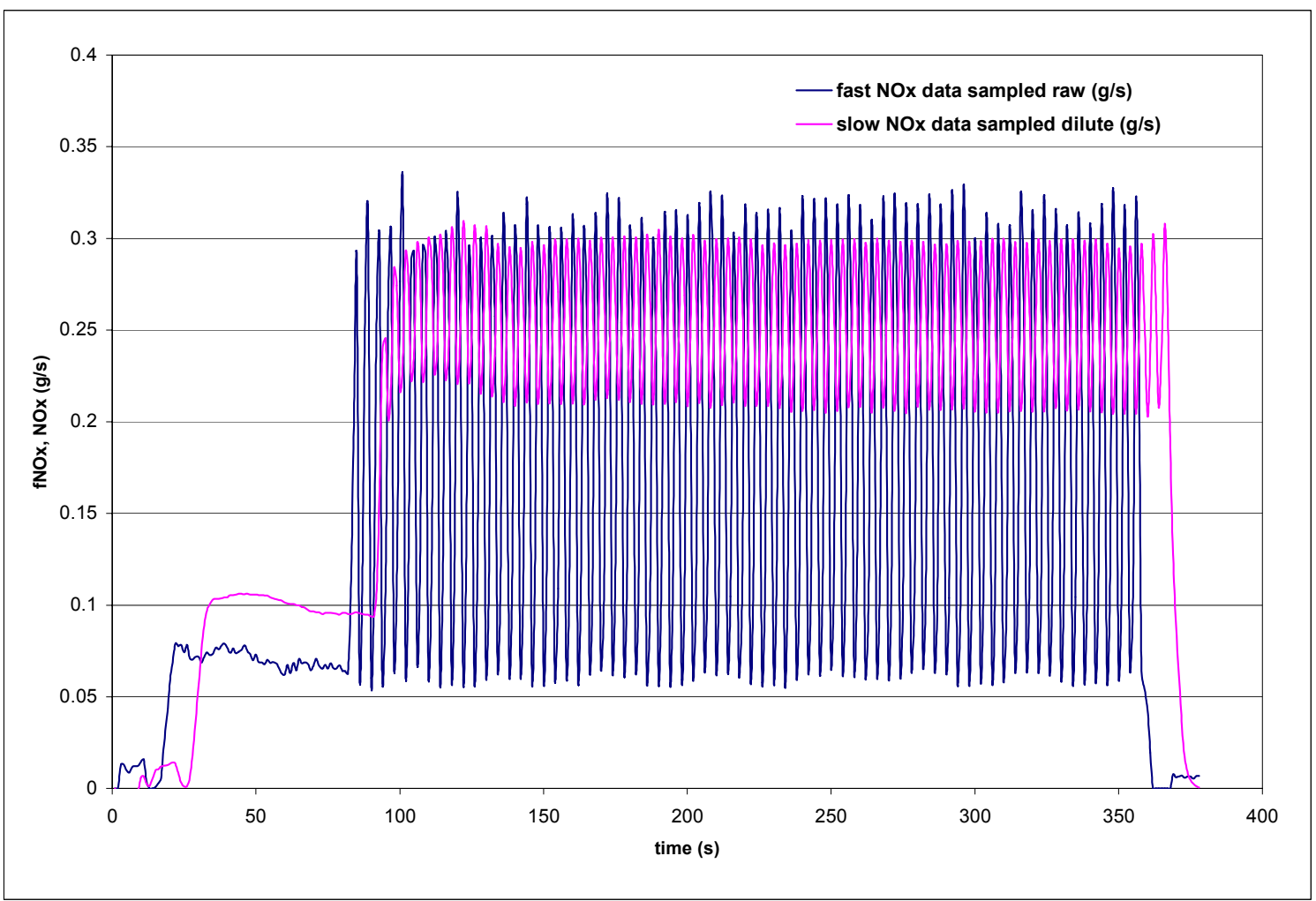

Figure 29 Variation of $\mathrm{NO}_{\mathrm{x}}$ emissions with time for the trapezoidal wave with 4seconds period of oscillations.

It is evident from the two figures that the amplitude of trapezoidal wave decreased for 4-second oscillation square wave for the slow $\mathrm{NO}_{\mathrm{x}}$ analyzer. This is because the signal capturing ability decreased. Power variation of the emissions is shown in Figure 32. Graphs with power plotted against time are shown in Figures 33 and 34. Once again it is evident that the fast $\mathrm{NO}_{\mathrm{x}}$ has a better correlation with power than slow $\mathrm{NO}_{\mathrm{x}}$. From Figures 32 and 33 it is evident that the fast $\mathrm{NO}_{\mathrm{x}}$ is a cluster of points for $20 \%$ power and full power whereas slow $\mathrm{NO}_{\mathrm{x}}$ is a straight line. This is again due to the dispersion effect of the slow $\mathrm{NO}_{\mathrm{x}}$. 


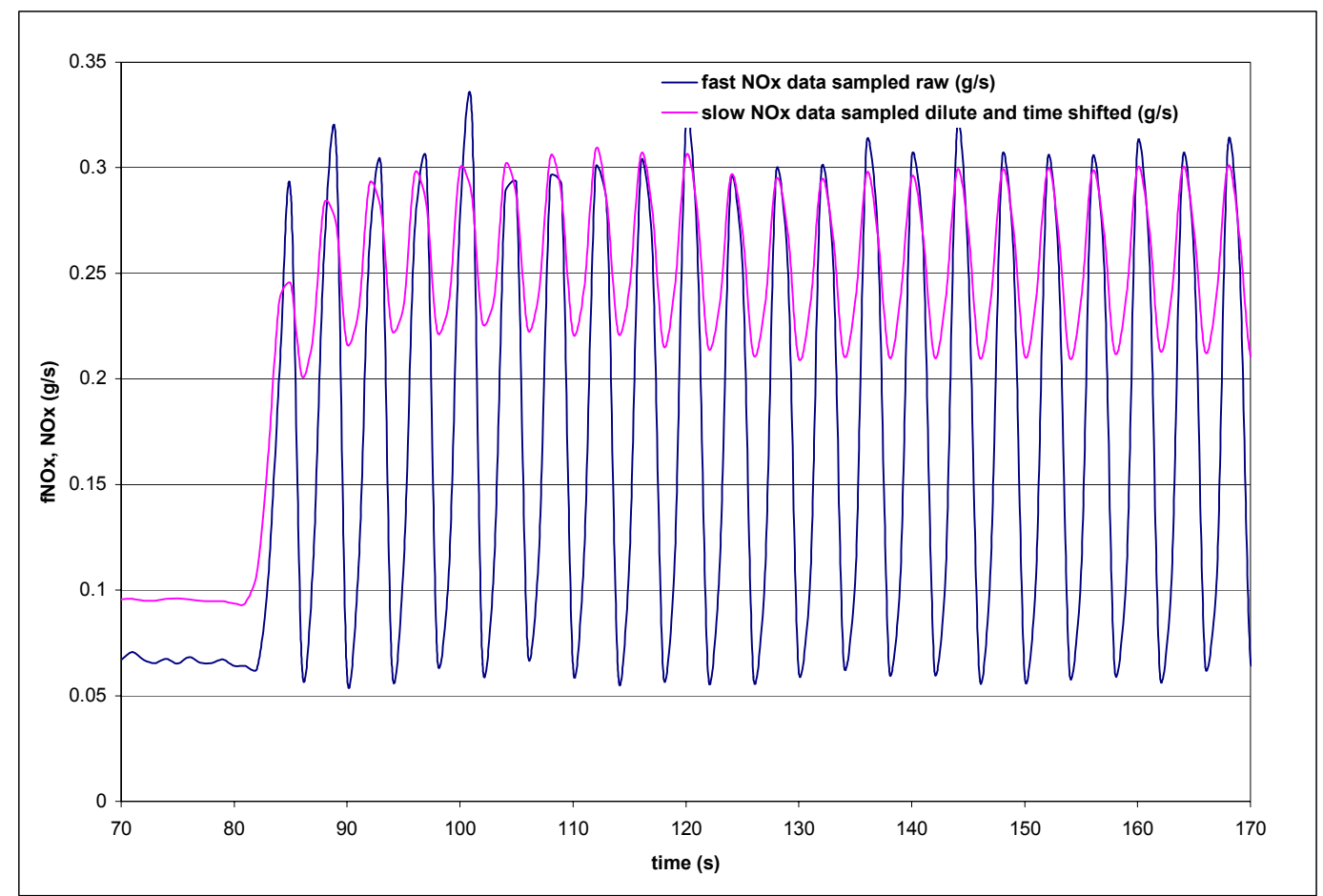

Figure 30 Variation of $\mathrm{NO}_{\mathrm{x}}$ emissions from the two analyzers with a time shift of 10 seconds for slow NOx for the case of the trapezoidal wave with a 4-second period of oscillation.

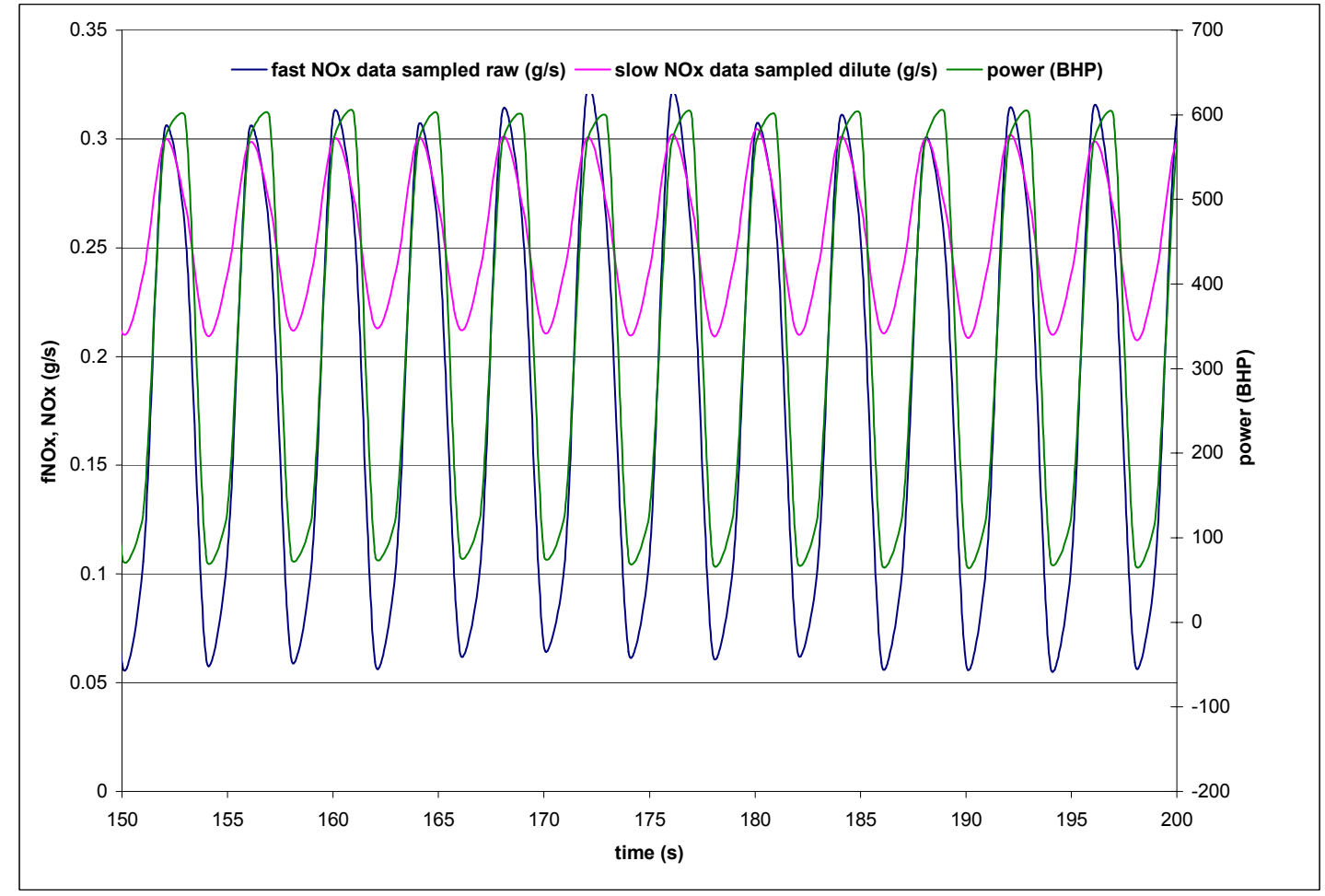

Figure 31 Power and $\mathrm{NO}_{\mathrm{x}}$ emissions variation with time for the trapezoidal wave with 4-second period of oscillations. 


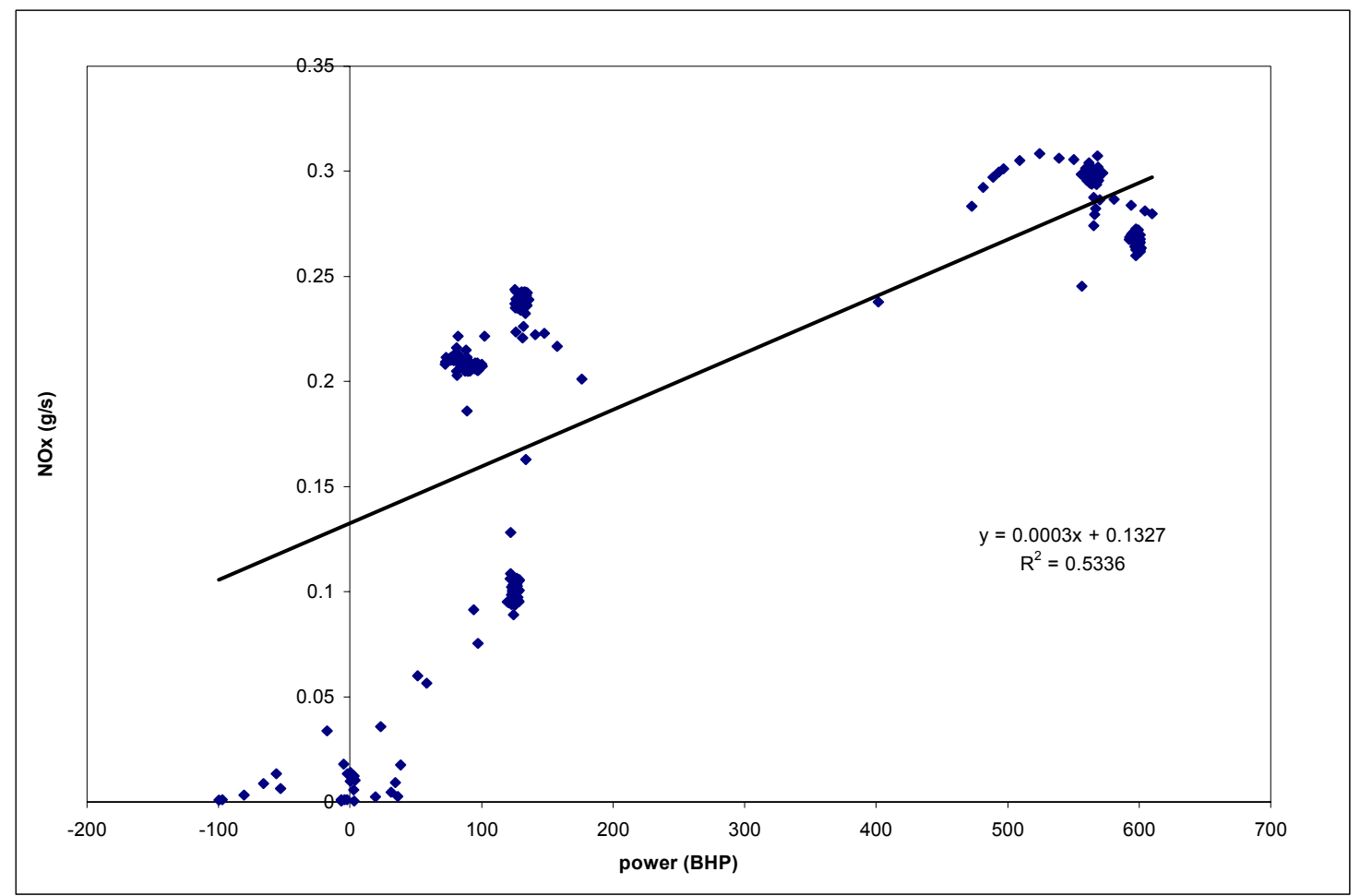

Figure 32 Relation between slow $\mathrm{NO}_{\mathrm{x}}$ and power for the trapezoidal wave cycle with 4-second period of oscillations.

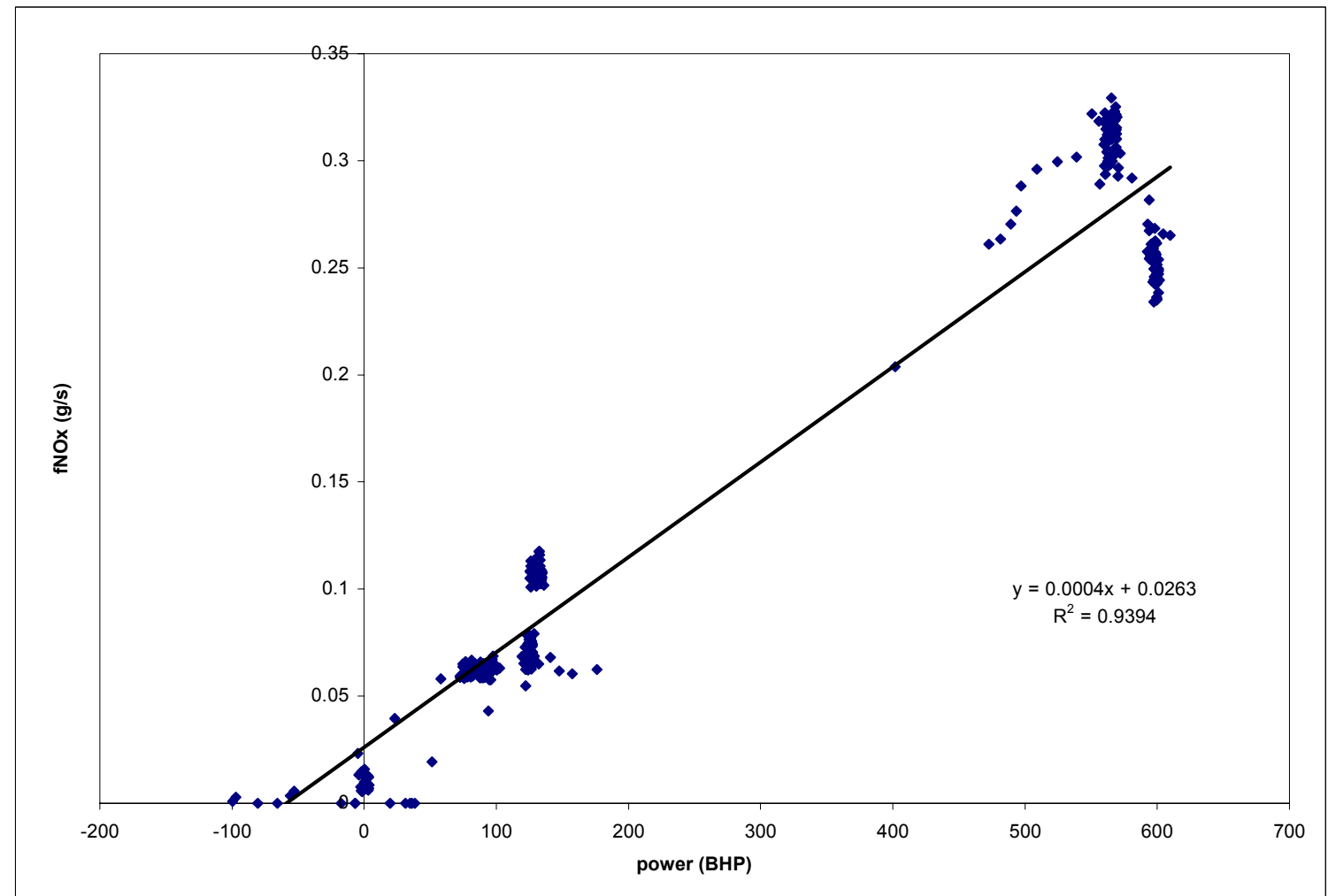

Figure 33 Relation between fast $\mathrm{NO}_{\mathrm{x}}$ and power for the trapezoidal wave with 4second period of oscillations. 


\subsubsection{2-Second Period Oscillation}

In addition to the 10 and 4 -sec period oscillations, a trapezoidal wave cycle with 2-second period of oscillations was run on the DDC Series 60 engine. The purpose of different time periods was to look at the analyzer signal capturing capacity. The 2seconds oscillations showed a still more dampening in the amplitude of the trapezoidal wave for the slow $\mathrm{NO}_{\mathrm{x}}$ data whereas for the fast $\mathrm{NO}_{\mathrm{x}}$ data the signal was almost the same. The signal was almost a straight line. This was due to the increase in frequency of the trapezoidal signal. Figure 34 shows variation of $\mathrm{NO}_{\mathrm{x}}$ and time with no time shift and Figure 35 shows the same with time shift. $\mathrm{NO}_{\mathrm{x}}$ emissions with power are as shown in Figure 36. It is evident from the figure that the power signal was ahead of the fast $\mathrm{NO}_{\mathrm{x}}$ signal by about 1 -sec, which was almost negligible. Variation of power and $\mathrm{NO}_{\mathrm{x}}$ gives an $\mathrm{R}^{2}$ value of 0.2 whereas the same plot with $\mathrm{fNO}_{\mathrm{x}}$ gives an $\mathrm{R}^{2}$ value of 0.8 indicating that fast $\mathrm{NO}_{\mathrm{x}}$ has a better correlation with power than slow $\mathrm{NO}_{\mathrm{x}}$. The dispersion effect of the slow $\mathrm{NO}_{\mathrm{x}}$ analyzer is evident from the straight line of $\mathrm{NO}_{\mathrm{x}}$ emissions in Figure 37 when the power is about $100 \mathrm{BHP}$ and the instantaneous nature of the fast $\mathrm{NO}_{\mathrm{x}}$ is evident from the cluster of points in Fig 38 when the power is 100 BHP. Work done during the cycle was $22.66 \mathrm{bhp}-\mathrm{hr}$ and the break specific fuel consumed was $0.373 \mathrm{lb} . / \mathrm{bhp}-\mathrm{hr}$. Brake specific $\mathrm{NO}_{\mathrm{x}}$ emissions for the cycle while continuous sampling from the slow anlayzer

were $3.208 \mathrm{~g} / \mathrm{bhp}-\mathrm{hr}$. Cycle average $\mathrm{NO}_{\mathrm{x}}$ emissions were $0.168 \mathrm{~g} / \mathrm{s}$ and $0.191 \mathrm{~g} / \mathrm{s}$ for the fast and slow $\mathrm{NO}_{\mathrm{x}}$ respectively. 


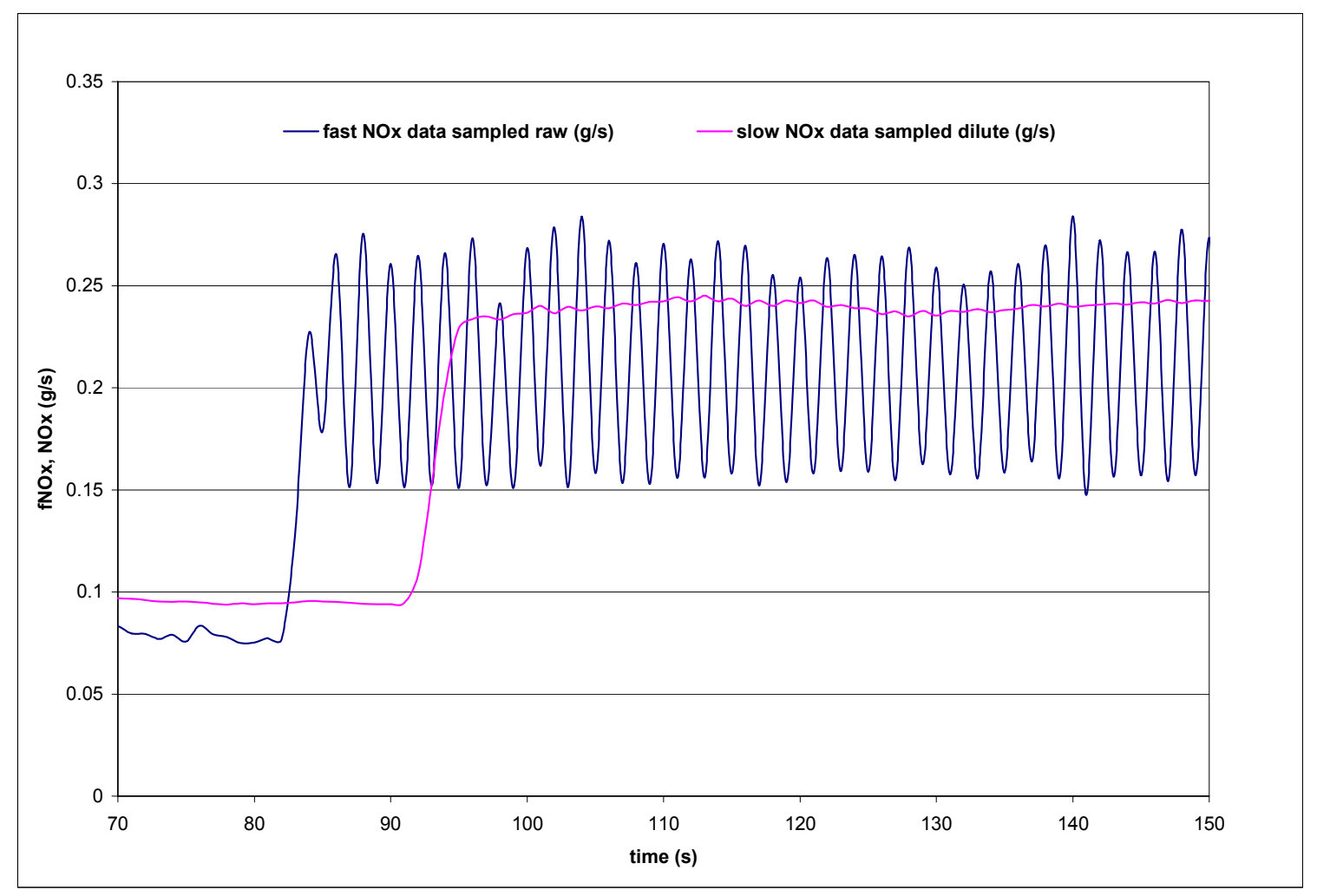

Figure 34 Variation of $\mathrm{NO}_{\mathrm{x}}$ emissions with time for a part of the trapezoidal wave cycle with a 2 -second period of oscillation.

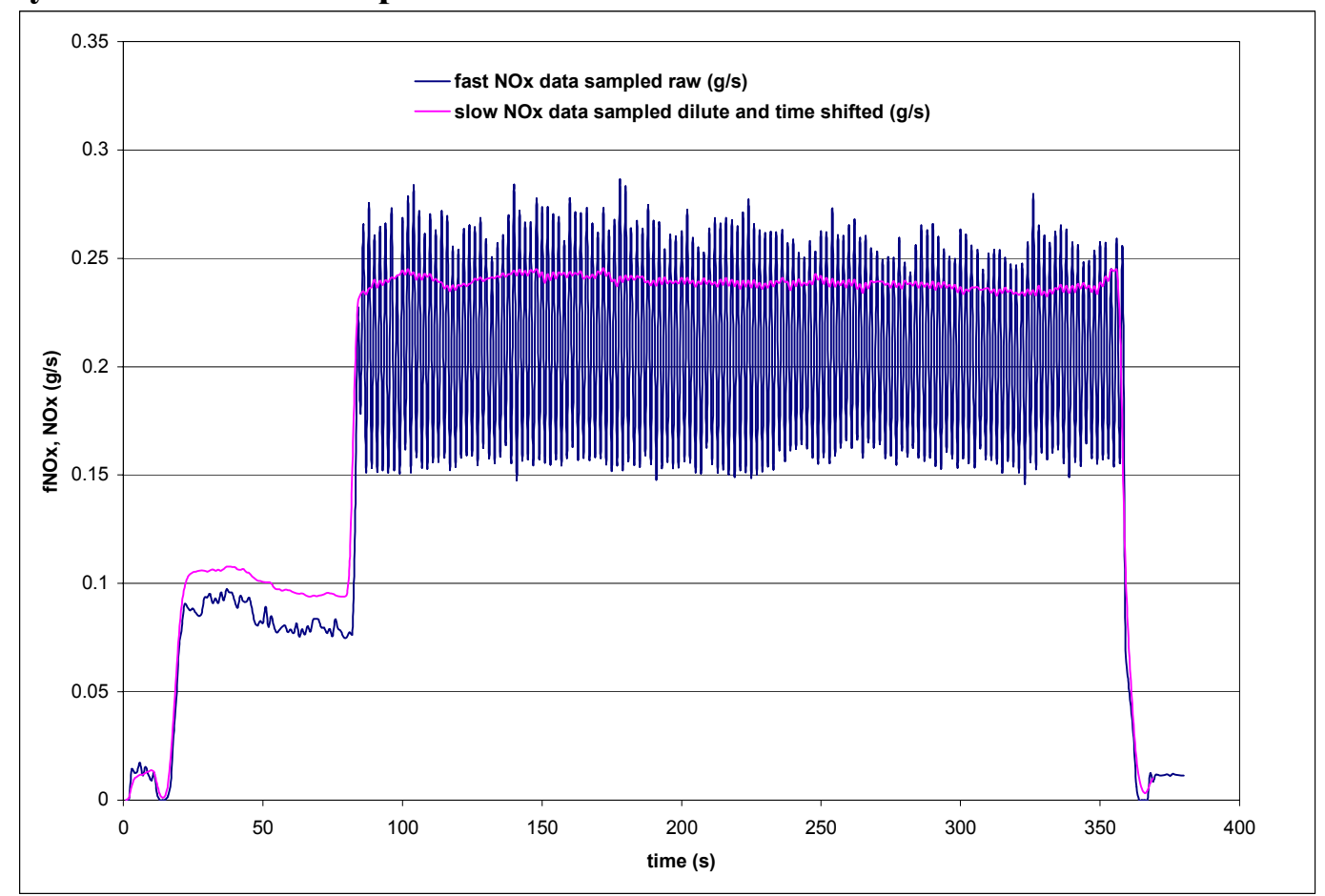

Figure 35 Variation of $\mathrm{NO}_{\mathrm{x}}$ emissions with time for the trapezoidal wave with 2second period of oscillations and with slow $\mathrm{NO}_{\mathrm{x}}$ shifted for the time delay. 


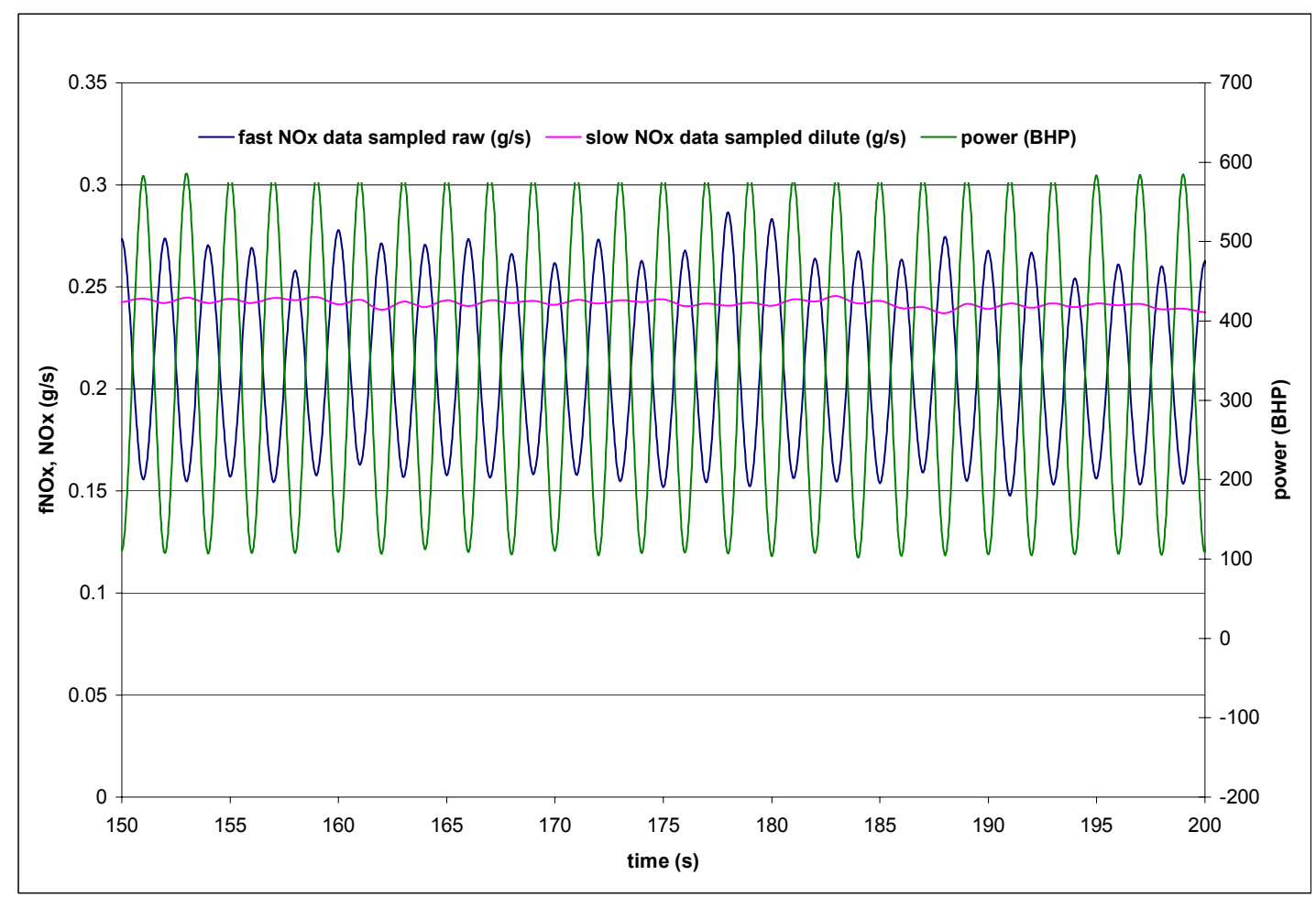

Figure 36 Power and $\mathrm{NO}_{\mathrm{x}}$ emission variation with time for a part of the trapezoidal wave with a 2 -second period of oscillations.

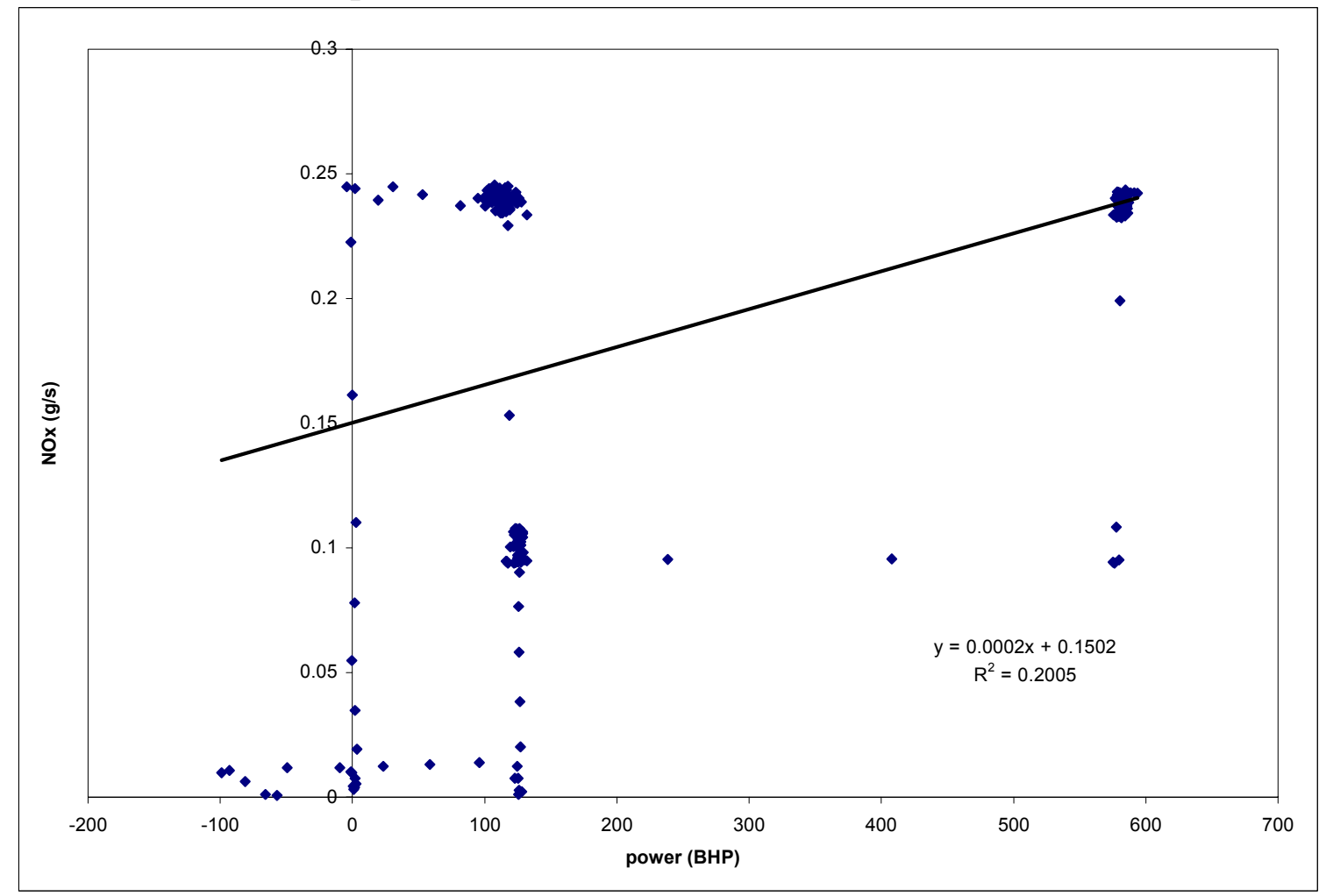

Figure 37 Relation between power and slow $\mathrm{NO}_{\mathbf{x}}$ emissions for the trapezoidal wave cycle with a 2-second period of oscillations. 


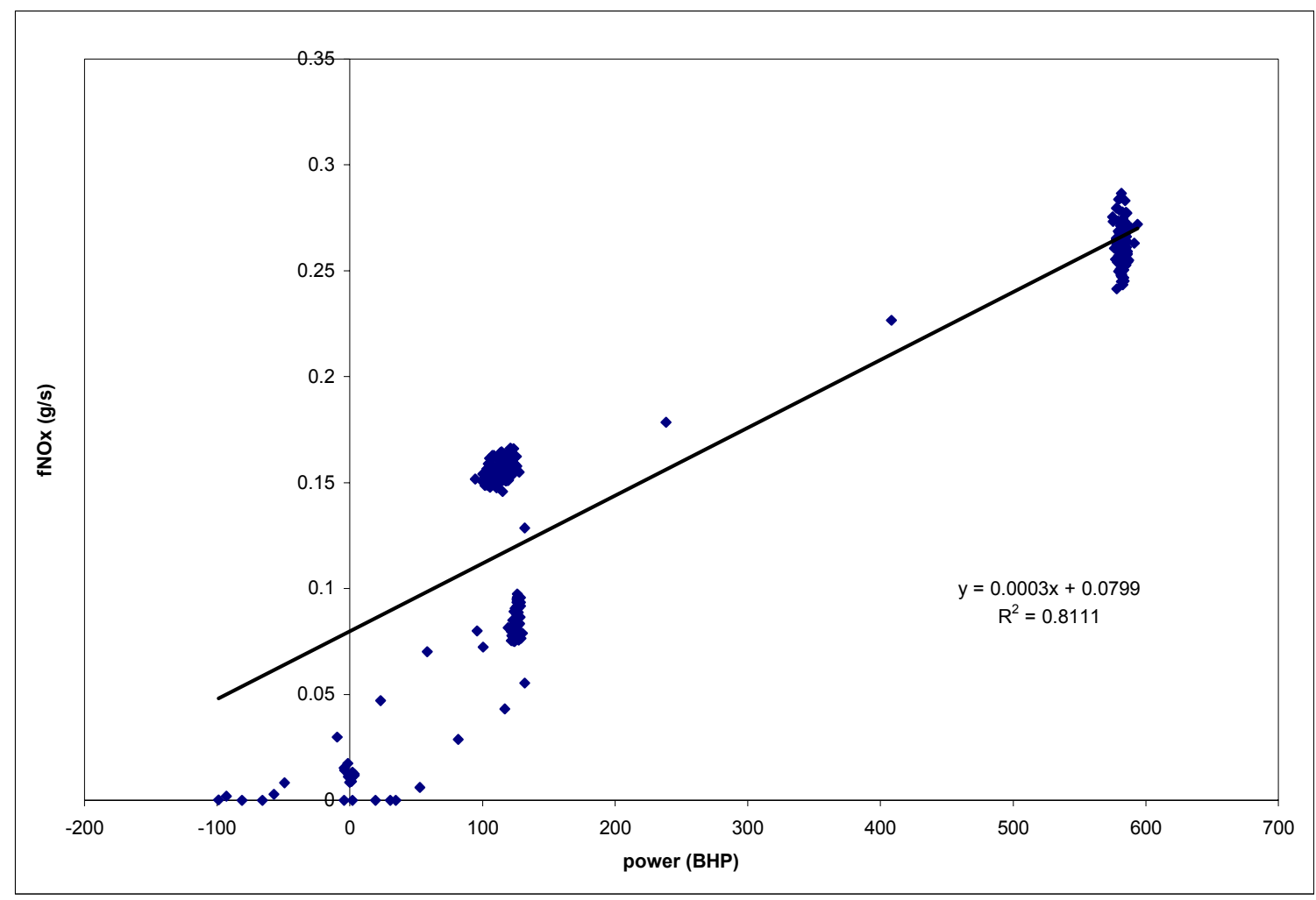

Figure 38 Relation between power and fast $\mathrm{NO}_{\mathrm{x}}$ emissions for the trapezoidal wave with 2-second period of oscillations.

\subsubsection{1-Second Period Oscillation}

The final trapezoidal wave test was with a time period of 1-second. $\mathrm{NO}_{\mathrm{x}}$ emissions variation with time for the 1-second oscillations trapezoidal wave are shown in Figure 39. From the figures it is evident that 1-second oscillations trapezoidal wave for the slow $\mathrm{NO}_{\mathrm{x}}$ data is almost a straight line and the amplitude is almost totally dampened. This is because of the increase in frequency of oscillation. But the fast $\mathrm{NO}_{\mathrm{x}}$ analyzer captures the signal very fast and the amplitude of the trapezoidal wave is almost same for all the oscillations. Total and average $\mathrm{NO}_{\mathrm{x}}$ is increased a little for slow $\mathrm{NO}_{\mathrm{x}}$ data. Actual work done during the cycle is $23.3 \mathrm{bhp}-\mathrm{hr}$ and the brake specific fuel consumed is 0.375 lb./bhp-hr. Brake specific $\mathrm{NO}_{\mathrm{x}}$ emissions for the entire cycle with the slow $\mathrm{NO}_{\mathrm{x}}$ analyzer are $3.141 \mathrm{~g} / \mathrm{bhp}-\mathrm{hr}$. Cycle average emissions are $0.119 \mathrm{~g} / \mathrm{s}$ and $0.193 \mathrm{~g} / \mathrm{s}$ measured using fast $\mathrm{NO}_{\mathrm{x}}$ analyzer and slow $\mathrm{NO}_{\mathrm{x}}$ analyzer respectively. 


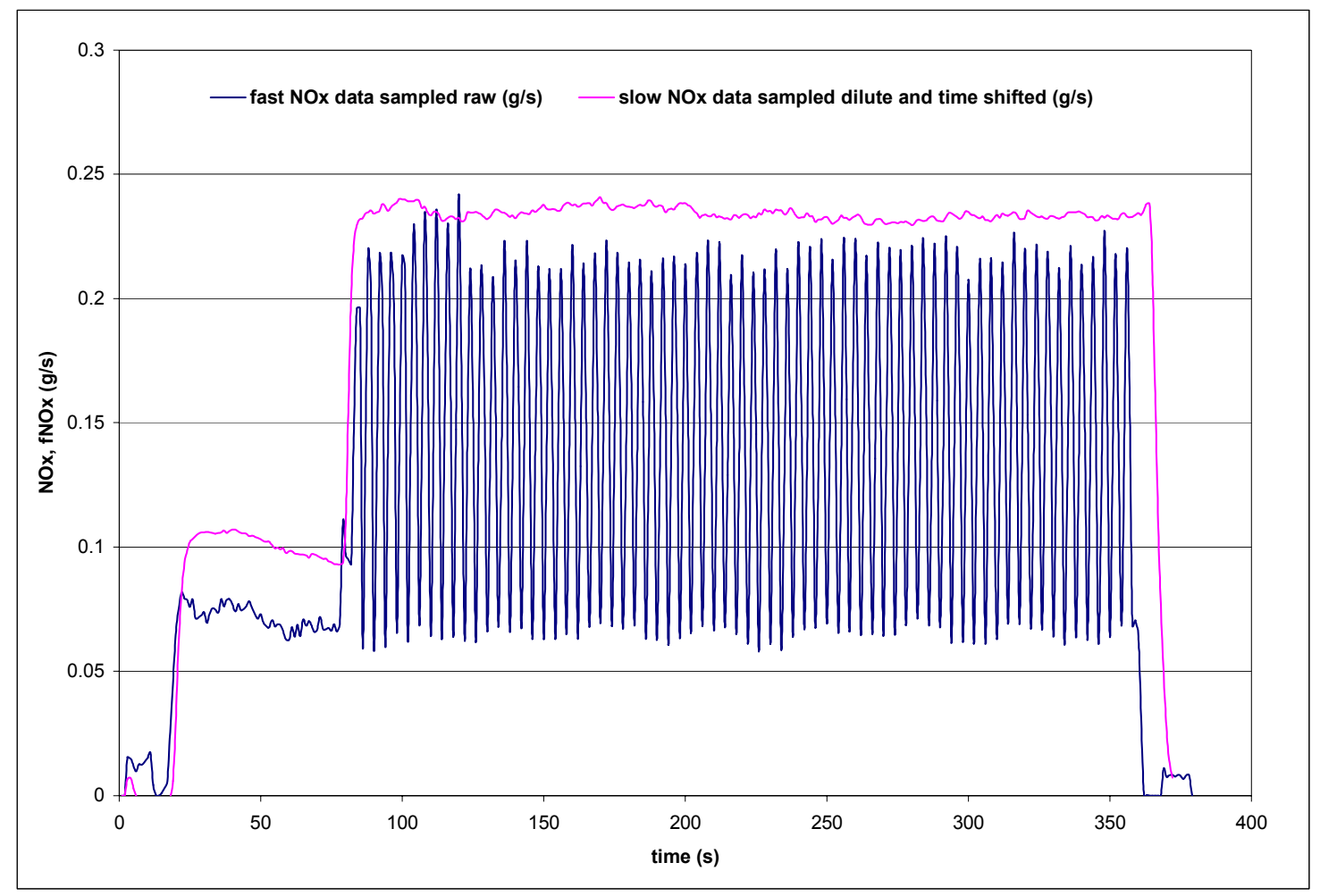

Figure 39 Slow and fast $\mathrm{NO}_{\mathrm{x}}$ emissions plotted against time for the trapezoidal wave with 1- second period of oscillations with time shifted slow $\mathrm{NO}_{\mathrm{x}}$.

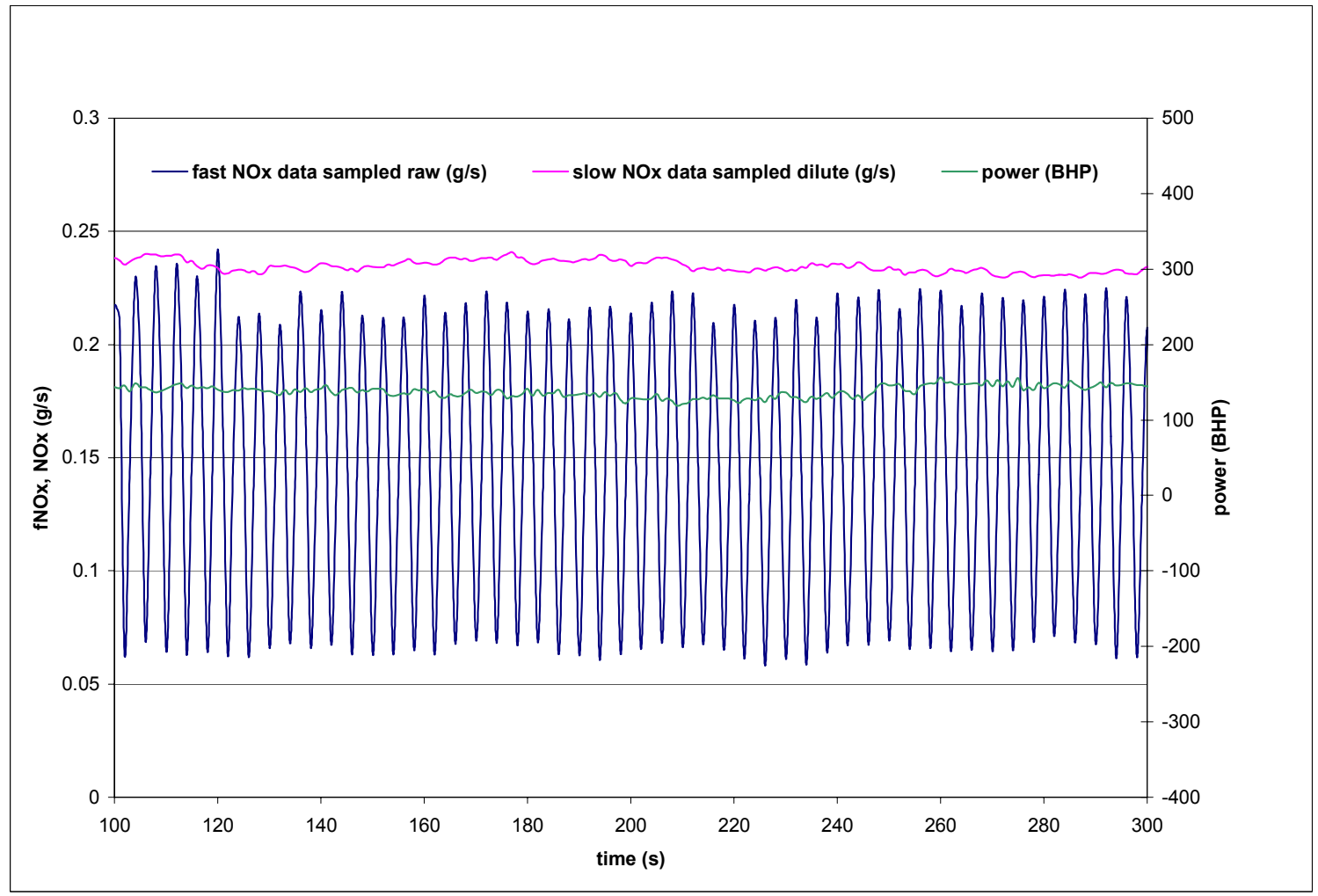

Figure 40 Variation of power, slow $\mathrm{NO}_{\mathrm{x}}$ and fast $\mathrm{NO}_{\mathrm{x}}$ with time for the trapezoidal wave with 1-second period of oscillations. 
From Figure 42 where power and $\mathrm{NO}_{\mathrm{x}}$ emissions are plotted against time, it is evident that power and slow $\mathrm{NO}_{\mathrm{x}}$ have a trapezoidal wave almost as a straight line but the fast $\mathrm{NO}_{\mathrm{x}}$ emissions still represent a wave with good amplitude. Increase in frequency of oscillations did not really have much effect on the amplitude of the wave. This represents instantaneous signal capturing nature of the fast $\mathrm{NO}_{\mathrm{x}}$ analyzer.

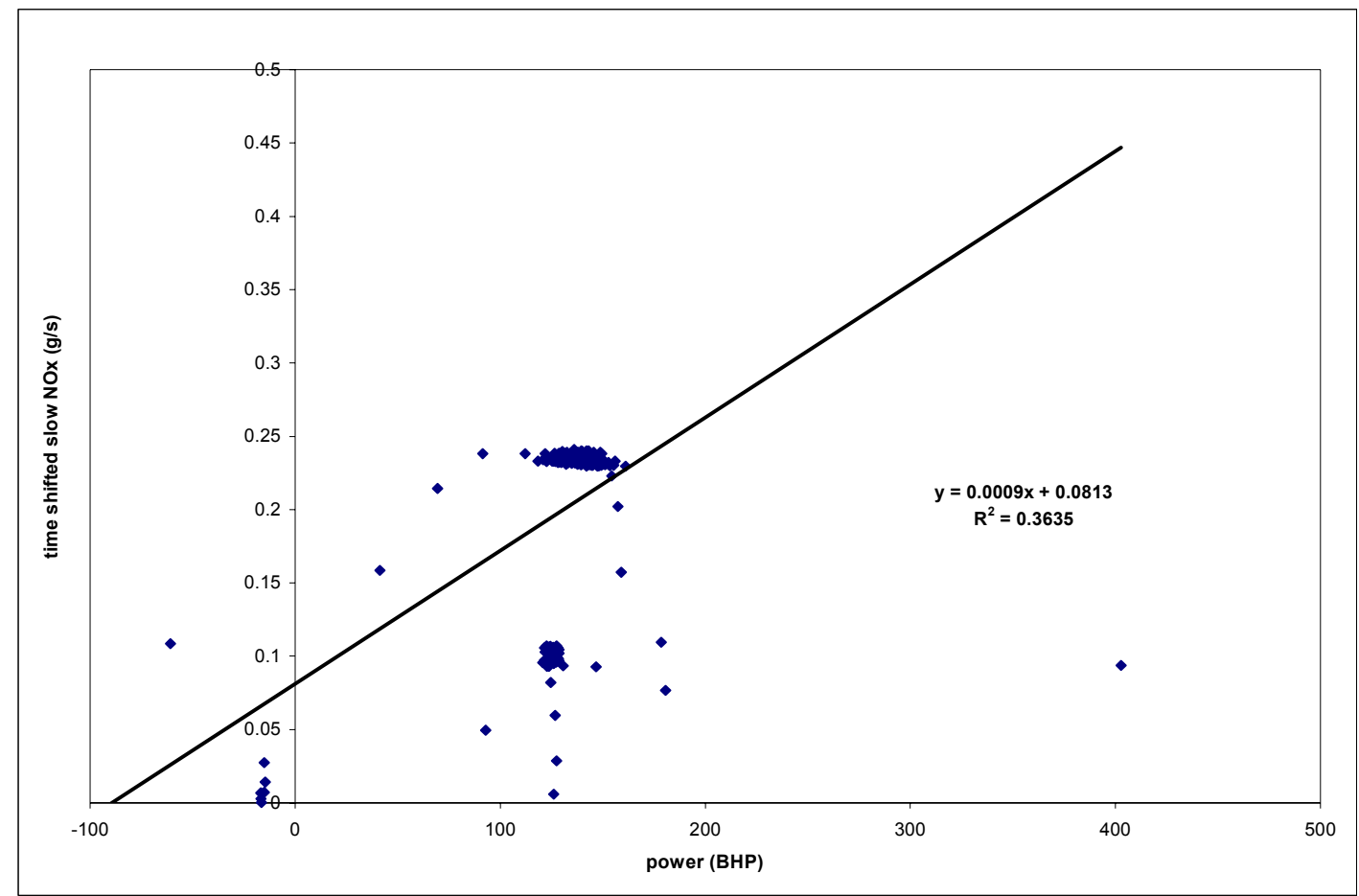

Figure 41 Relation between power and time shifted slow $\mathrm{NO}_{\mathrm{x}}$ for the case of the trapezoidal wave with 1-seond period of oscillations. 


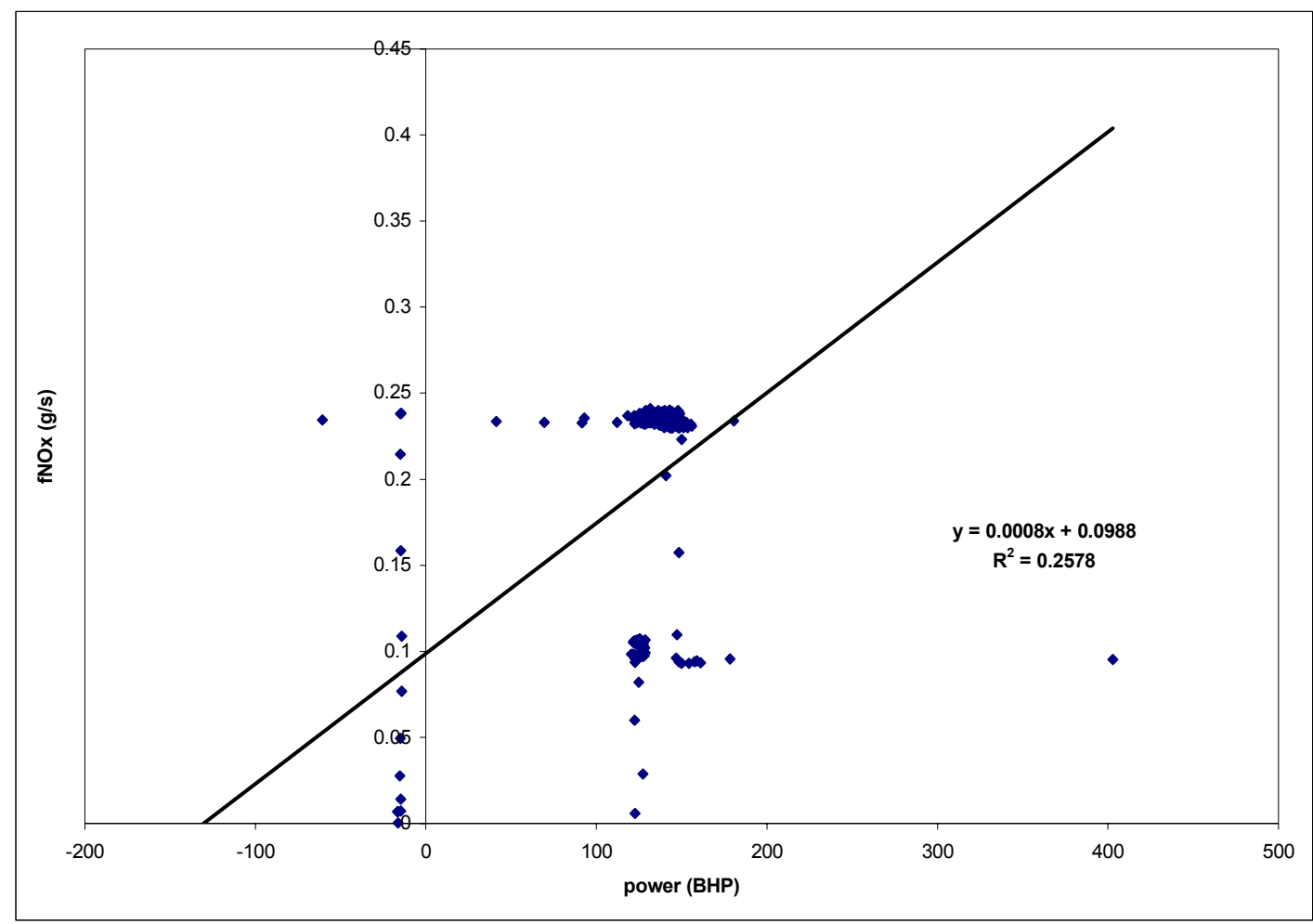

Figure 42 Relation between fast $\mathrm{NO}_{\mathrm{x}}$ and power for the trapezoidal wave with 1second period of oscillations.

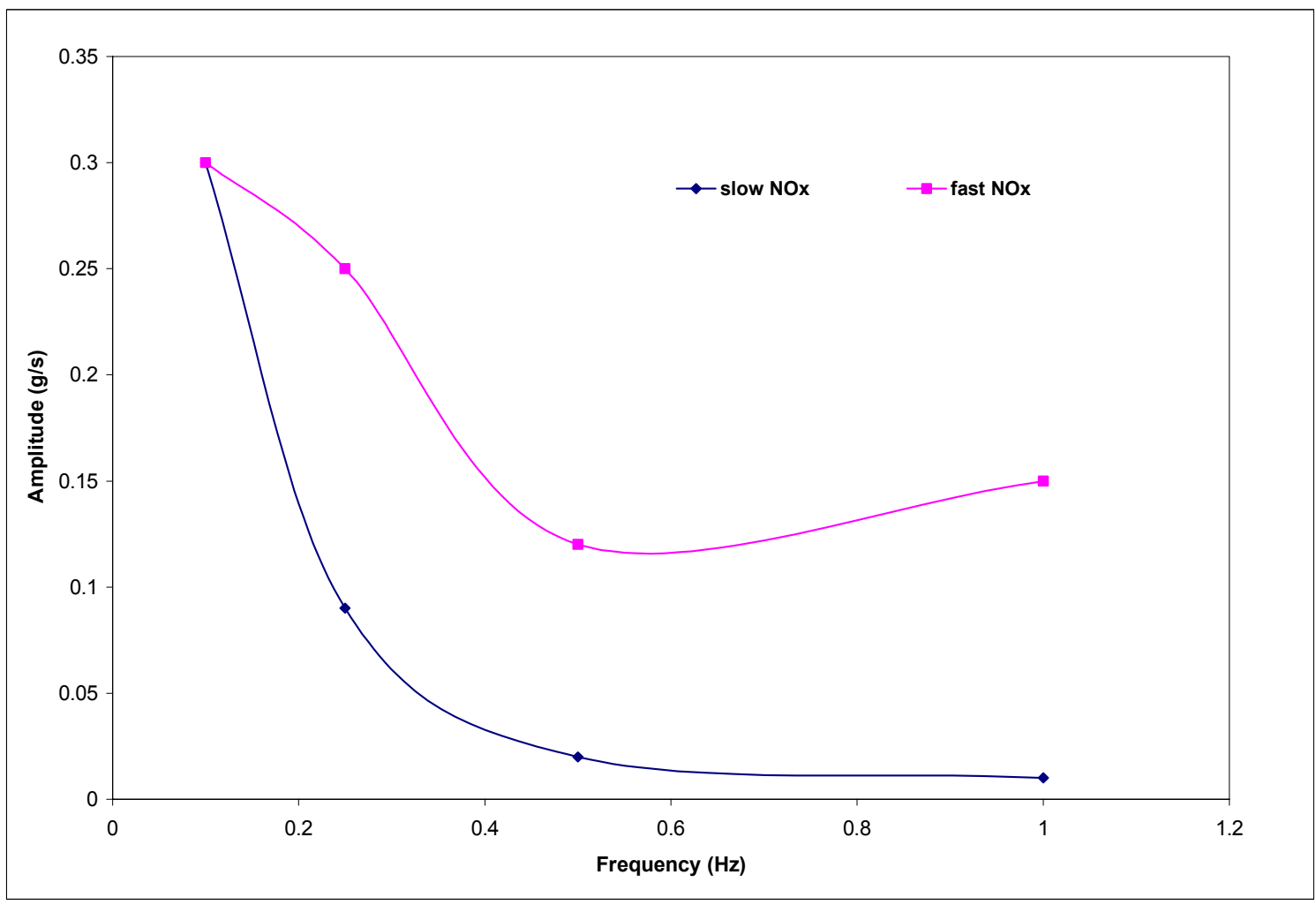

Figure 43 Variation of amplitude with frequency for the trapezoidal tests 
From the trapezoidal wave tests, it is concluded that increase in frequency of oscillation results in a decrease in $\mathrm{NO}_{\mathrm{x}}$ emissions (measured using slow analyzer). Also, the effect of frequency change on the emissions measurement using fast $\mathrm{NO}_{\mathrm{x}}$ analyzer is almost negligible The results obtained from all the four trapezoidal tests performed on the DDC Series 60 engine are plotted in Figures 43 and 44. Figure 43 shows the variation of amplitude of the trapezoidal waves for the $\mathrm{NO}_{\mathrm{x}}$ emissions with frequency. It is evident from the figure that there is a drastic decrease in the amplitude of slow $\mathrm{NO}_{\mathrm{x}}$ trapezoidal waves when compared to the amplitude of the fast $\mathrm{NO}_{\mathrm{x}}$ trapezoidal waves. This could be explained as the effect of signal capturing capacity of the slow and fast $\mathrm{NO}_{\mathrm{x}}$ analyzers. The slow $\mathrm{NO}_{\mathrm{x}}$ could capture signal upto a frequency of $0.1 \mathrm{~Hz}$ i.e. a time period of 10 seconds. At a frequency of $0.25 \mathrm{~Hz}$ ( 4 seconds time period) its amplitude drastically decreased to 0.09 indicating that the slow $\mathrm{NO}_{\mathrm{x}}$ could not capture the signal. Similarly, for still higher frequencies (lower periods of oscillations 2 seconds and 1 second), the amplitude becomes very low indicating the poor capability of the analyzer. The fast $\mathrm{NO}_{\mathrm{x}}$ analyzer shows better signal capturing capacity, as there is no sudden decrease in the amplitude values of the trapezoidal waves. Also there is an increase in the amplitude of the wave for a frequency of $1 \mathrm{~Hz}$. Figure 44 shows the variation of the $\mathrm{R}^{2}$ of the power fit of $\mathrm{NO}_{\mathrm{x}}$ emissions with frequency of engine oscillations. From the figure it is evident that the $\mathrm{R}^{2}$ values of slow $\mathrm{NO}_{\mathrm{x}}$ decrease suddenly whereas those for fast $\mathrm{NO}_{\mathrm{x}}$ do not. There is a better correlation between fast $\mathrm{NO}_{\mathrm{x}}$ and power than slow $\mathrm{NO}_{\mathrm{x}}$ and power at lower frequencies but at the frequency of $1 \mathrm{~Hz}$, both the analyzers fail to capture the signal properly and hence the $\mathrm{R}^{2}$ value of the power fit is very low. The reason could also be the inability of the engine to respond to a very low time period of oscillation and hence the power and the emissions would not have a better correlation. 


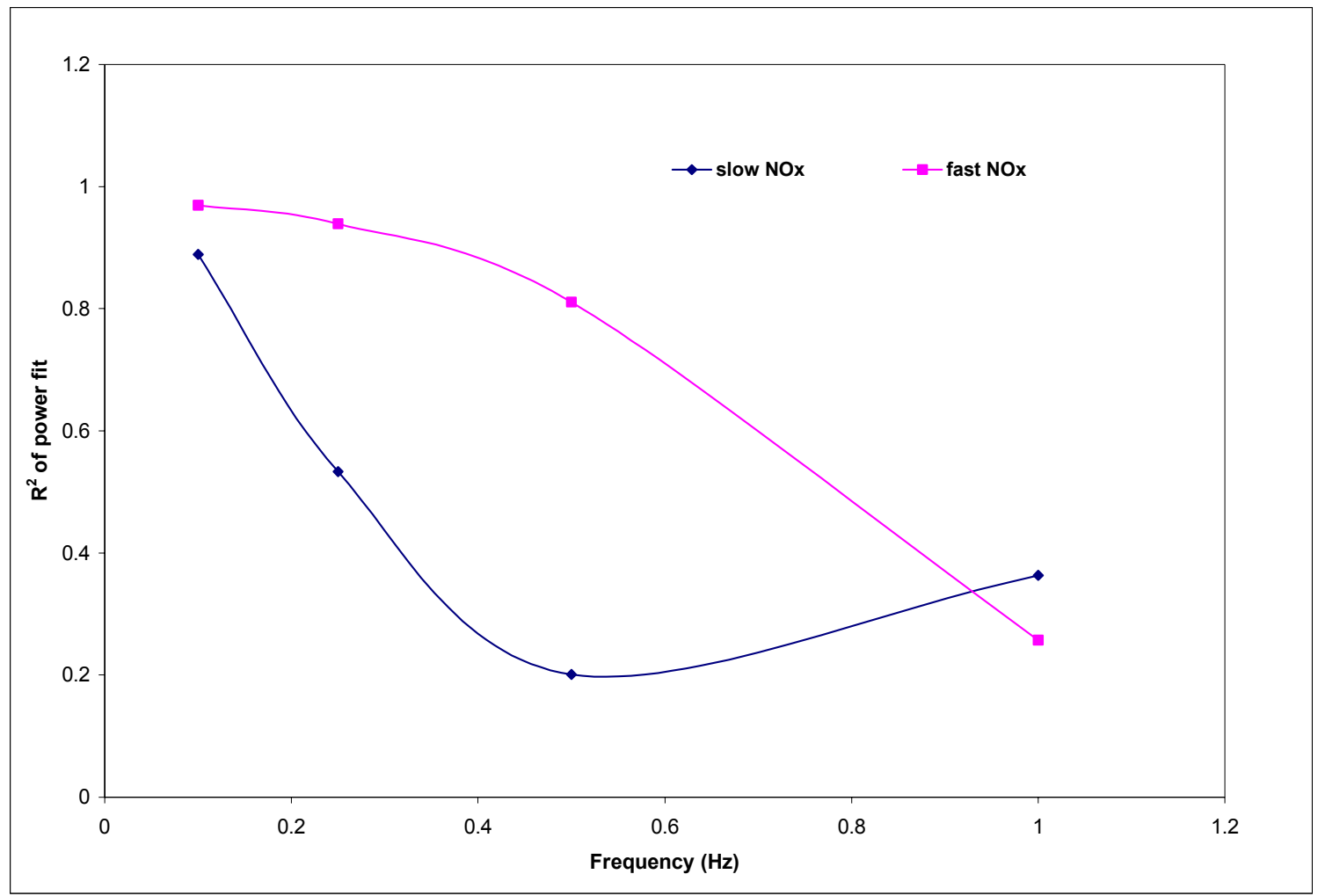

\section{Figure 44 Variation of $R^{2}$ of power fit with frequency for trapezoidal waves.}

\subsubsection{Transient cycle test results}

Transient test cycles used for this research are FTP, CSHVR-E, WVU 5 peak-E, Highway-E, ETC-E which are discussed in detail in chapter III. Most of the transient test cycles were run on the DDC Series 60, 2000 Model year engine. A few of them were executed on the other engines. All the FTP cycles performed on six heavy-duty diesel engines are presented in this section and the results are discussed. The transient cycles are shown in the Appendix of this thesis.

\subsubsection{Federal Transient Procedure (FTP)}

The first among the transient test cycles conducted on the DDC Series 60 (2000 Model Year) is the FTP cycle. It is a hot start test. Work done during the cycle for a period of 1200 seconds is 33.04 bhp-hr. Brake Specific Fuel Consumed by the engine for the FTP cycle is $0.422 \mathrm{lb}$./bhp-hr. The brake specific $\mathrm{NO}_{\mathrm{x}}$ emissions measured by the slow $\mathrm{NO}_{\mathrm{x}}$ analyzer, for the FTP cycle are $2.62 \mathrm{~g} / \mathrm{bhp}-\mathrm{hr}$. The brake specific $\mathrm{NO}_{\mathrm{x}}$ 
emissions measured using the fast $\mathrm{NO}_{\mathrm{x}}$ analyzer are $2.76 \mathrm{~g} / \mathrm{bhp}-\mathrm{hr}$. The cycle average values of the $\mathrm{NO}$ and $\mathrm{NO}_{\mathrm{x}}$ emissions for the FTP cycle are $0.072 \mathrm{~g} / \mathrm{s}$ and $0.091 \mathrm{~g} / \mathrm{s}$ respectively. Figure 44 shows $\mathrm{NO}$ and $\mathrm{NO}_{\mathrm{x}}$ emissions measured using slow and fast $\mathrm{NO}_{\mathrm{x}}$ analyzers with respect to time. From the figure it is evident that there is a time shift between slow $\mathrm{NO}_{\mathrm{x}}$ and fast $\mathrm{NO}_{\mathrm{x}}$ curves. This shift is due to the delay and dispersion in the sample train and the analyzer type. Figure 45 shows the variation of $\mathrm{NO}_{\mathrm{x}}$ emissions with time after applying a time shift of 10 seconds to the slow $\mathrm{NO}_{\mathrm{x}}$ data and Figure 46 shows the variation of NOx emissions with time without the time shift. Figure 47 shows the same with power added as another parameter. From the figure it is evident that the fast $\mathrm{NO}$ emissions also have a time shift but it is relatively less (about 1 second) and this is due to the faster response of the analyzer. Time delay in $\mathrm{NO}_{\mathrm{x}}$ emissions is generally calculated based on the peak to peak correlation between power and $\mathrm{NO}_{\mathrm{x}}$. Figure 48 shows the correlation of power and $\mathrm{NO}_{\mathrm{x}}$ without time shift. And Figure 49 shows the same with a time shift of 10 seconds. The change in $\mathrm{R}^{2}$ value (by regression analysis) from 0.261 to 0.841 indicates that the correlation improves with time shift and it is also found to be the best with a time shift of 10 seconds. From Figure 47 it is also concluded that $\mathrm{NO}_{\mathrm{x}}$ emissions almost vary linearly with power. Hence, power based $\mathrm{NO}_{\mathrm{x}}$ models are developed by obtaining a best-fit curve for power and $\mathrm{NO}_{\mathrm{x}}$ emissions. The graph for slow $\mathrm{NO}_{\mathrm{x}}$ data plotted against power is as shown in Figure 49 and for the fast $\mathrm{NO}_{\mathrm{x}}$ data is as shown in Figure 50. The lower slope for the slow $\mathrm{NO}_{\mathrm{x}}$ is probably also a symptom of diffusion. 


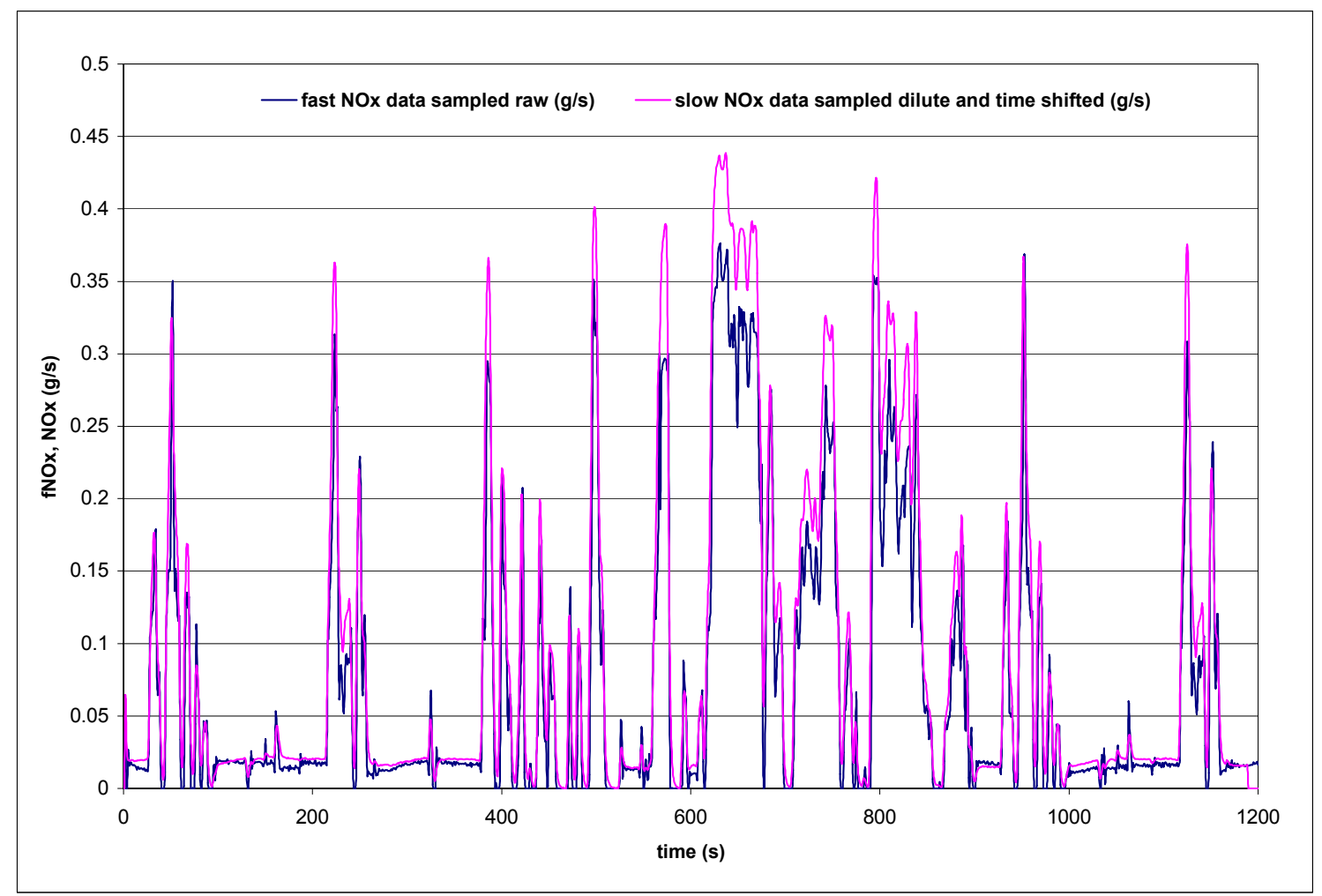

Figure 45 Variation of $\mathrm{NO}_{\mathrm{x}}$ emissions with time for a FTP cycle operated on the DDC Series 60 engine (slow $\mathrm{NO}_{\mathrm{x}}$ shifted for time delay).

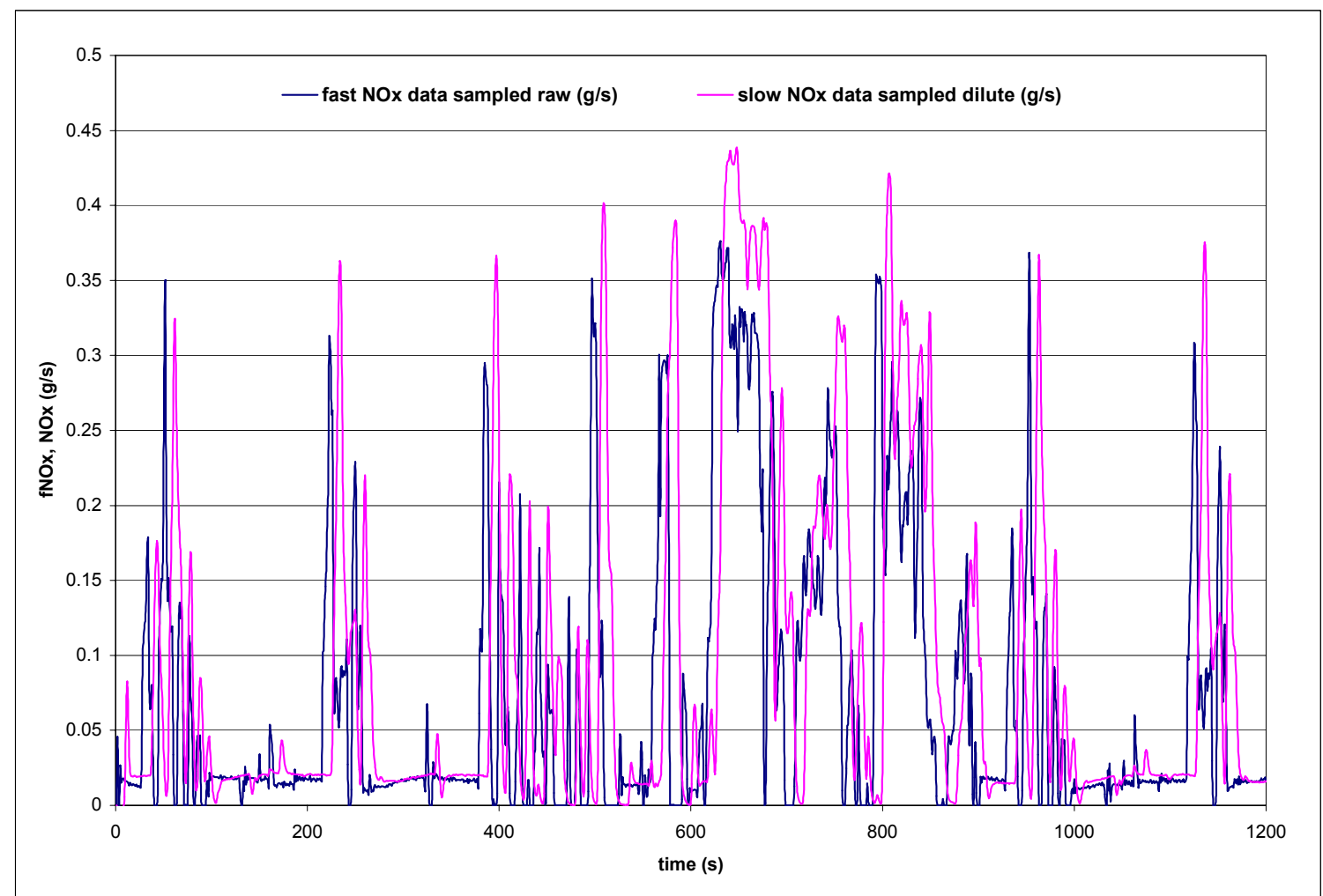

Figure 46 Variation of $\mathrm{NO}_{\mathrm{x}}$ emissions with time for a FTP cycle run on the DDC Series 60 engine. 


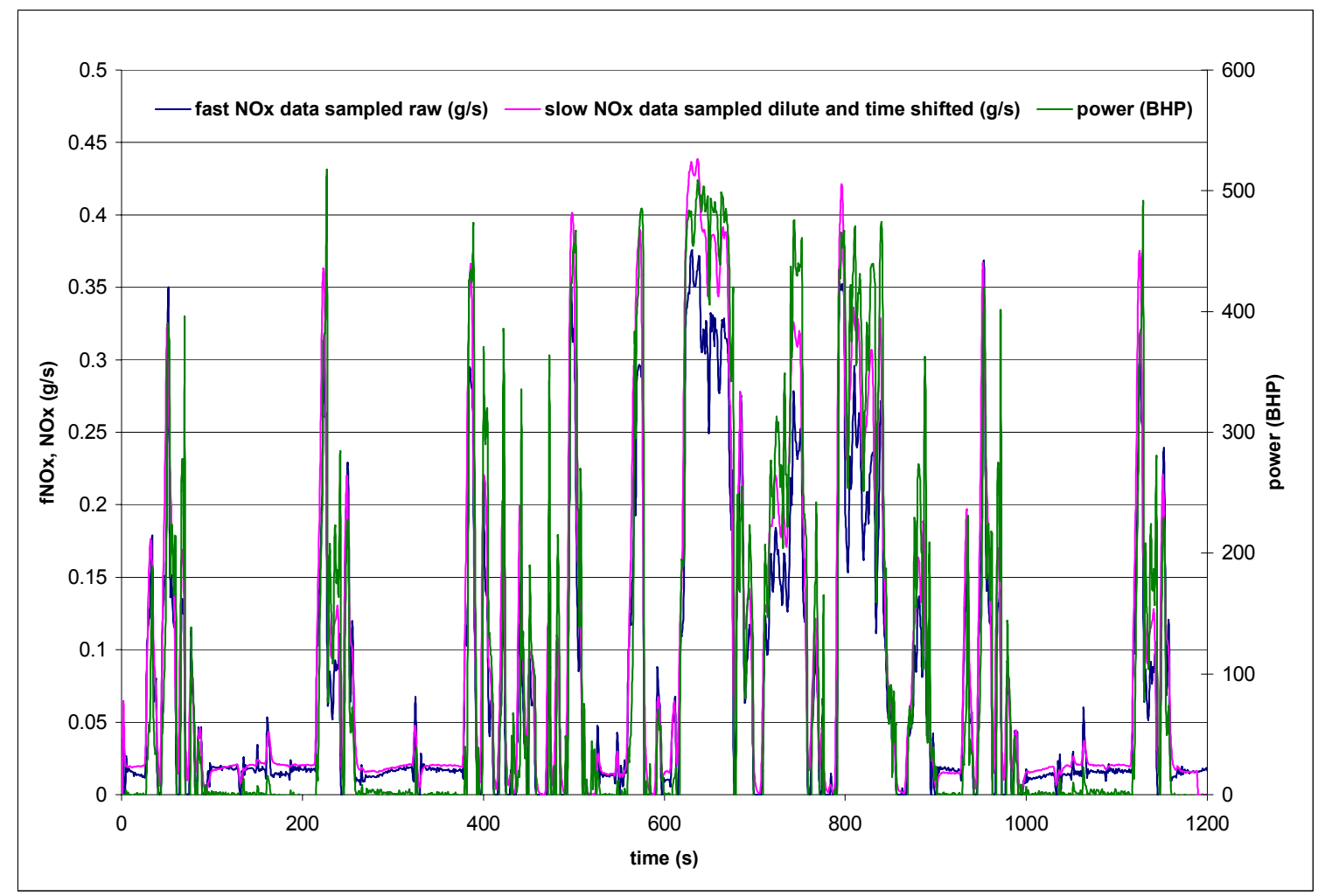

Figure 47 Variation of $\mathrm{NO}_{\mathrm{x}}$ emissions and power with time for the FTP cycle.

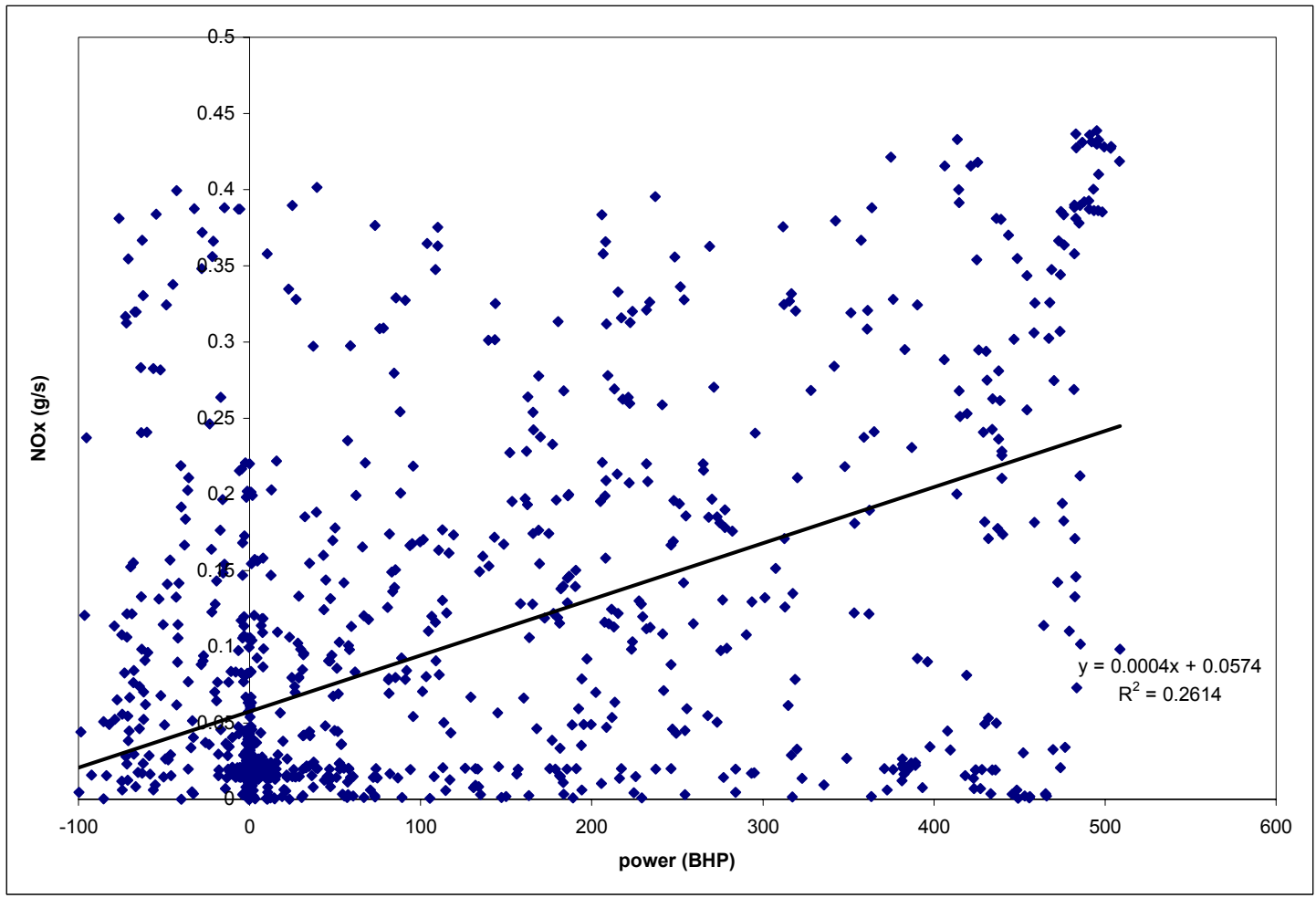

Figure 48 Relation between slow $\mathrm{NO}_{\mathrm{x}}$ (without any time shift) and power for the FTP cycle. 


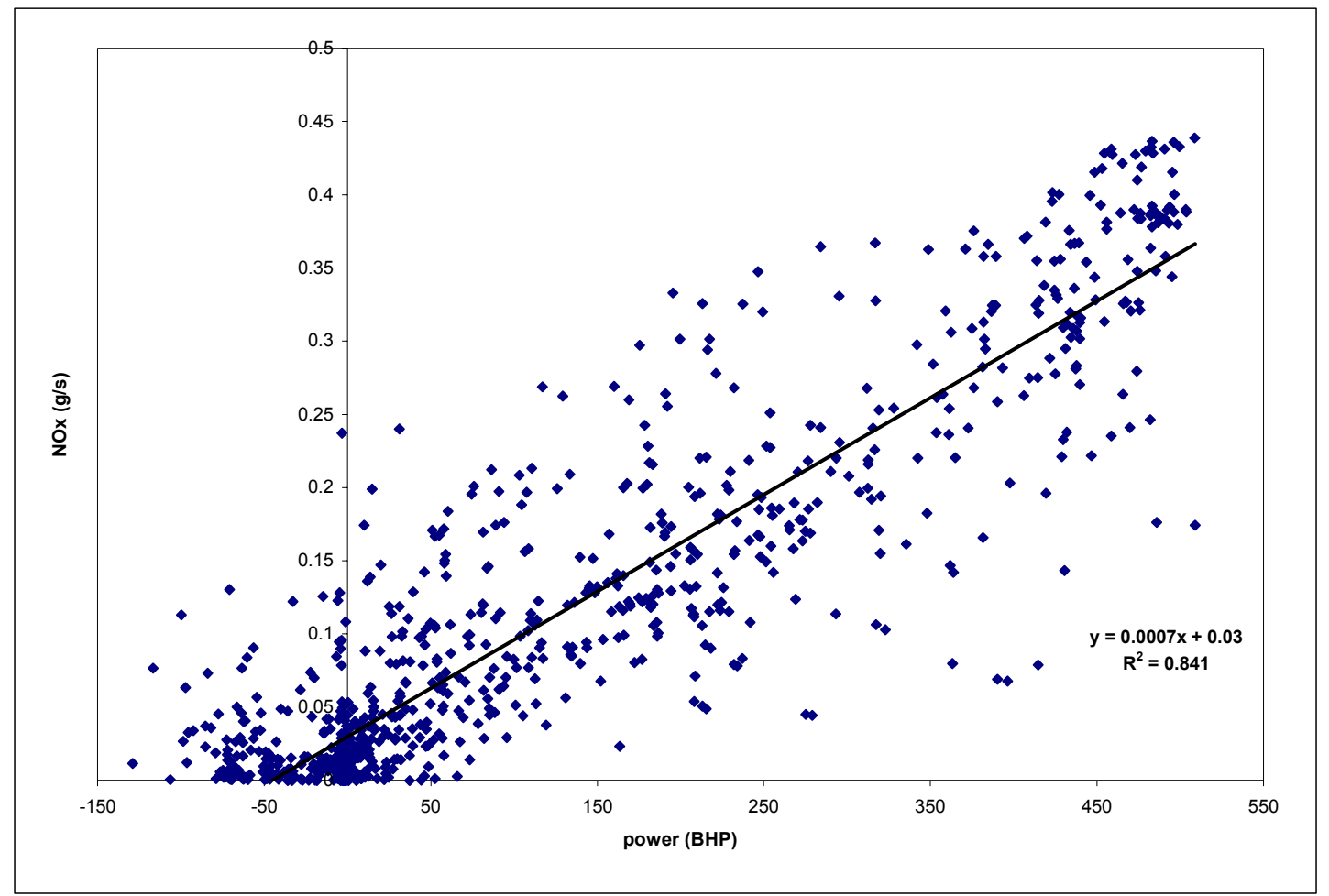

Figure 49 Relation between slow $\mathrm{NO}_{\mathrm{x}}$ (with time shift) and power for the FTP cycle

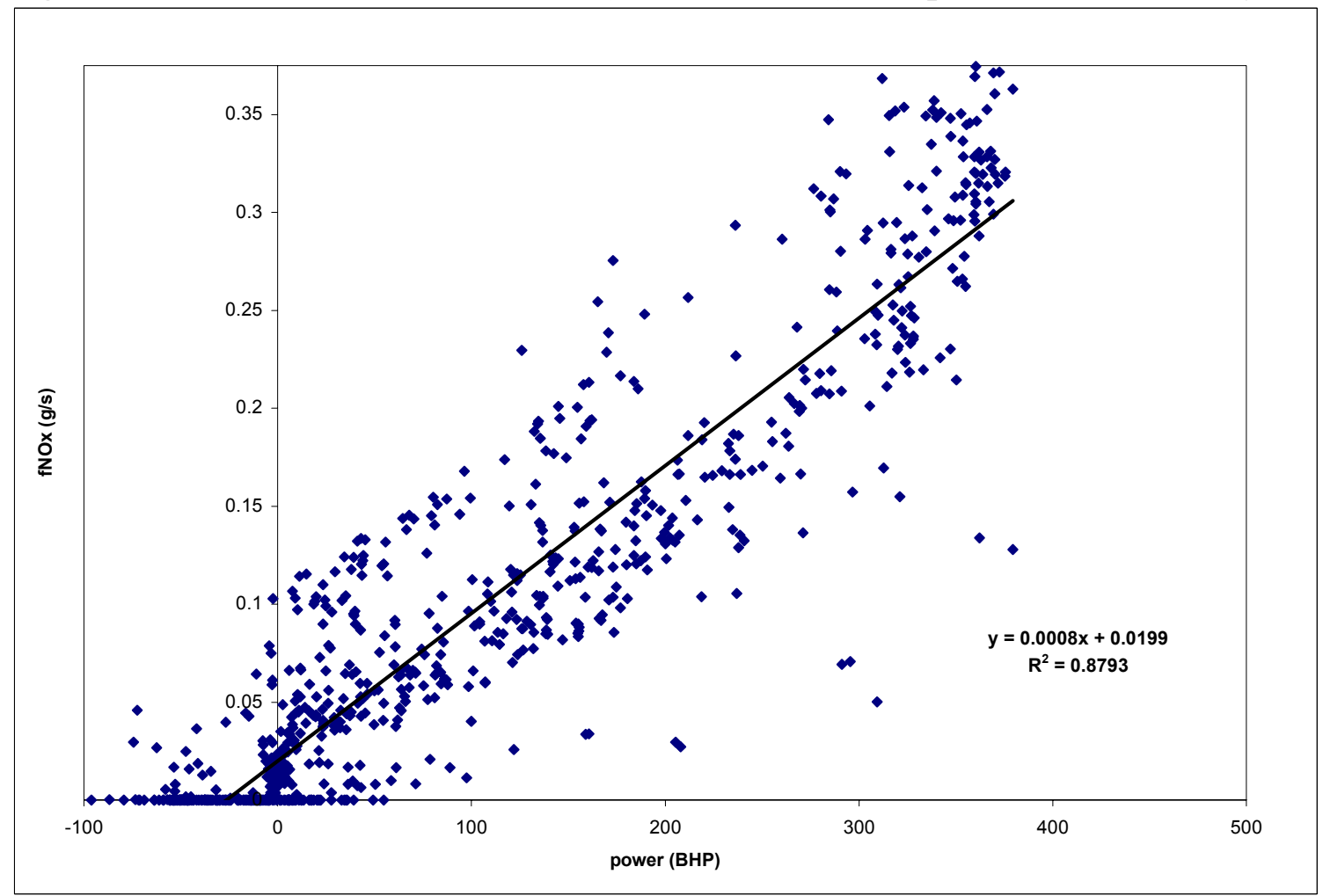

Figure 50 Relation between fast $\mathrm{NO}_{\mathrm{x}}$ and power for the FTP cycle.

In addition to the FTP cycle, other transient tests discussed in Section 4.2.3 were run on the DDC Series 60 and other engines. A brief summary of the test results is shown in the table below. 
Table 10 Transient engine cycle test measurements from slow and fast $\mathrm{NO}_{\mathrm{x}}$ analyzers.

\begin{tabular}{|l|l|l|}
\hline Cycle & $\begin{array}{l}\text { Slow } \mathrm{NO}_{\mathrm{x}} \\
\text { (cycle average values in g/s) }\end{array}$ & $\begin{array}{l}\text { Fast } \mathrm{NO}_{\mathrm{x}} \\
\text { (cycle average values in g/s })\end{array}$ \\
\hline ETC-E & 0.058 & 0.055 \\
\hline CSHVR-E & 0.035 & 0.033 \\
\hline WVU 5-Peak-E & 0.054 & 0.037 \\
\hline Highway-E & 0.056 & 0.052 \\
\hline
\end{tabular}

The graphs for each of the tests are given in the Appendix.

In general, the correlation between slow $\mathrm{NO}_{\mathrm{x}}$ and power decreased a lot more than the correlation between fast $\mathrm{NO}_{\mathrm{x}}$ and power with increase in the transient nature of the cycle. Apart from the steady state, trapezoidal and transient tests performed on the DDC Series 60 (Model Year 2000) engine, $\mathrm{NO}_{\mathrm{x}}$ emissions were measured from 5 other heavyduty diesel engines. FTP cycles were conducted on them. Slow $\mathrm{NO}_{\mathrm{x}}$ data was measured using a Rosemount $\mathrm{NO}_{\mathrm{x}}$ Analyzer and fast $\mathrm{NO}_{\mathrm{x}}$ data was measured using a Cambustion fast NO analyzer. Both dilute and raw samples were taken simultaneously by Cambustion analyzer for some of the tests. Raw sample calculations were done using intake air as well as exhaust flowrate and both the results were compared. An Annubar was used to measure the exhaust flow rate. Research on intake and exhaust flowrates was done by Shade [27], Meyer [30] and Fuller [31]. A brief description of each of the tests operated on different engines is followed along with the test results.

\subsection{Tests on DDC Series 60 Engine, Model Year 1995}

DDC Series 60 engine was tested for $\mathrm{NO}_{\mathrm{x}}$ emissions using the FTP cycle. Figure 51 shows variation of $\mathrm{NO}_{\mathrm{x}}$ emissions with time for both the analyzers. Figure 52 shows the same with a time shift of 10 seconds. Raw $\mathrm{NO}_{\mathrm{x}}$ sample calculations are done using both intake air and exhaust flowrate. Initially for the tests on DDC Series 60, 2000 Model Year engine, only the intake air flow rate was used for the calculation of raw fast $\mathrm{NO}_{\mathrm{x}}$ data. In order to know the emissions values based on exhaust flowrate, the exhaust 
flowrate was recorded and used for calculating raw fast $\mathrm{NO}_{\mathrm{x}}$. The average emissions using intake airflow rate are $0.12 \mathrm{~g} / \mathrm{s}$ and those using exhaust flowrate are $0.17 \mathrm{~g} / \mathrm{s}$. Results are shown in Figure 53. Variation of power and $\mathrm{NO}_{\mathrm{x}}$ emissions with time is shown in Figure 54. Actual work done during the FTP cycle on this engine is $26.86 \mathrm{bhp}-$ $\mathrm{hr}$ and the brake specific fuel consumed is $0.345 \mathrm{lb}$./bhp-hr. Cycle average $\mathrm{NO}_{\mathrm{x}}$ emissions measured using slow $\mathrm{NO}_{\mathrm{x}}$ analyzer are $0.19 \mathrm{~g} / \mathrm{s}$ and those using the fast $\mathrm{NO}$ analyzer are $0.17 \mathrm{~g} / \mathrm{s} . \mathrm{NO}_{\mathrm{x}}$ and power plots are shown in Figures 55 and 56 . There is an increase in $\mathrm{R}^{2}$ value of fast $\mathrm{NO}_{\mathrm{x}}$ and power when compared to slow $\mathrm{NO}_{\mathrm{x}}$ and power. This shows a better correlation between fast $\mathrm{NO}_{\mathrm{x}}$ and power than slow $\mathrm{NO}_{\mathrm{x}}$. A fast $\mathrm{NO}_{\mathrm{x}}$ prediction model is developed for the FTP cycle on the DDC Series 60 (1995 Model Year) using a linear fit of the test data.

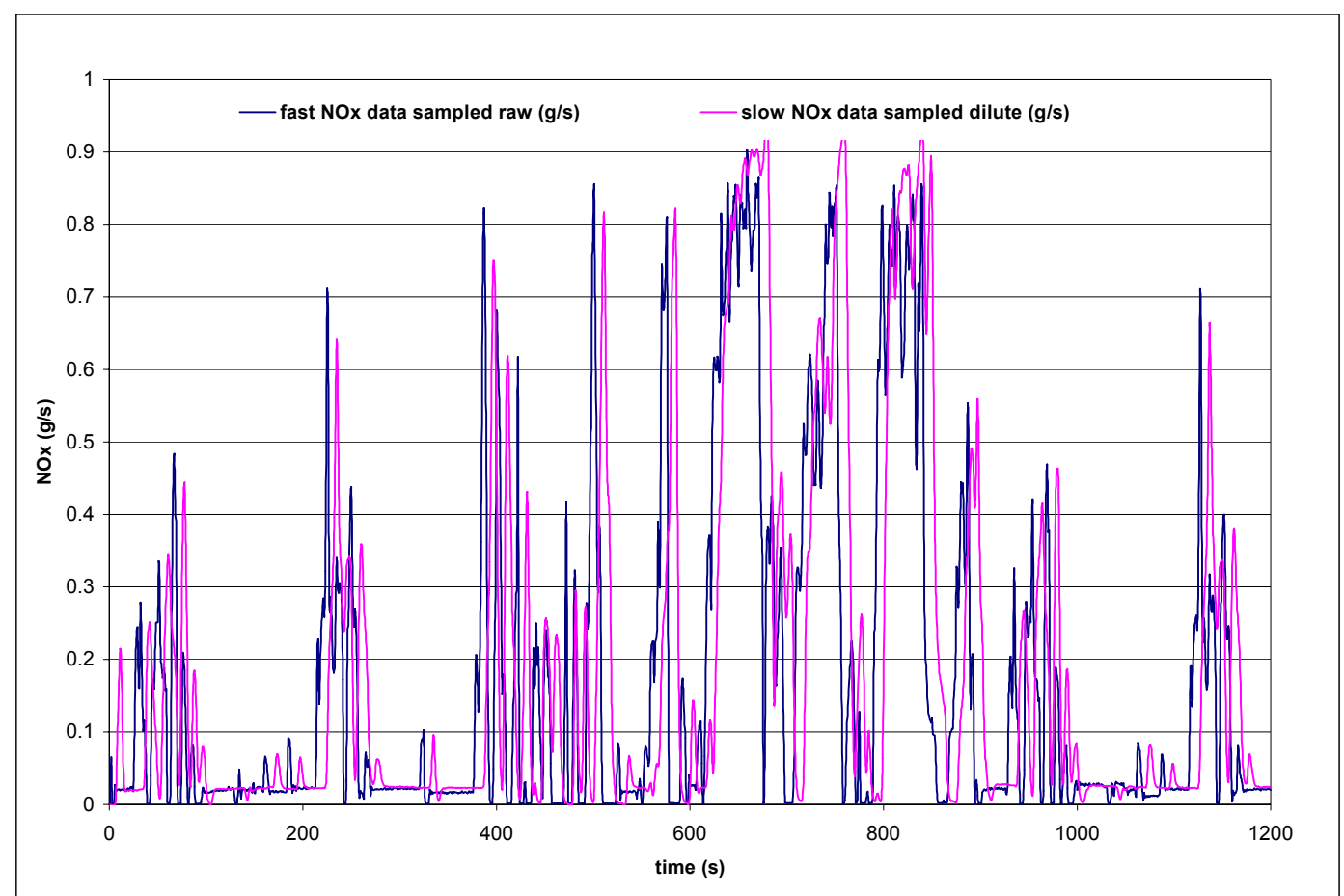

Figure 51 Variation of $\mathrm{NO}_{\mathrm{x}}$ emissions with power for a FTP cycle operated on the DDC Series 60 engine. 


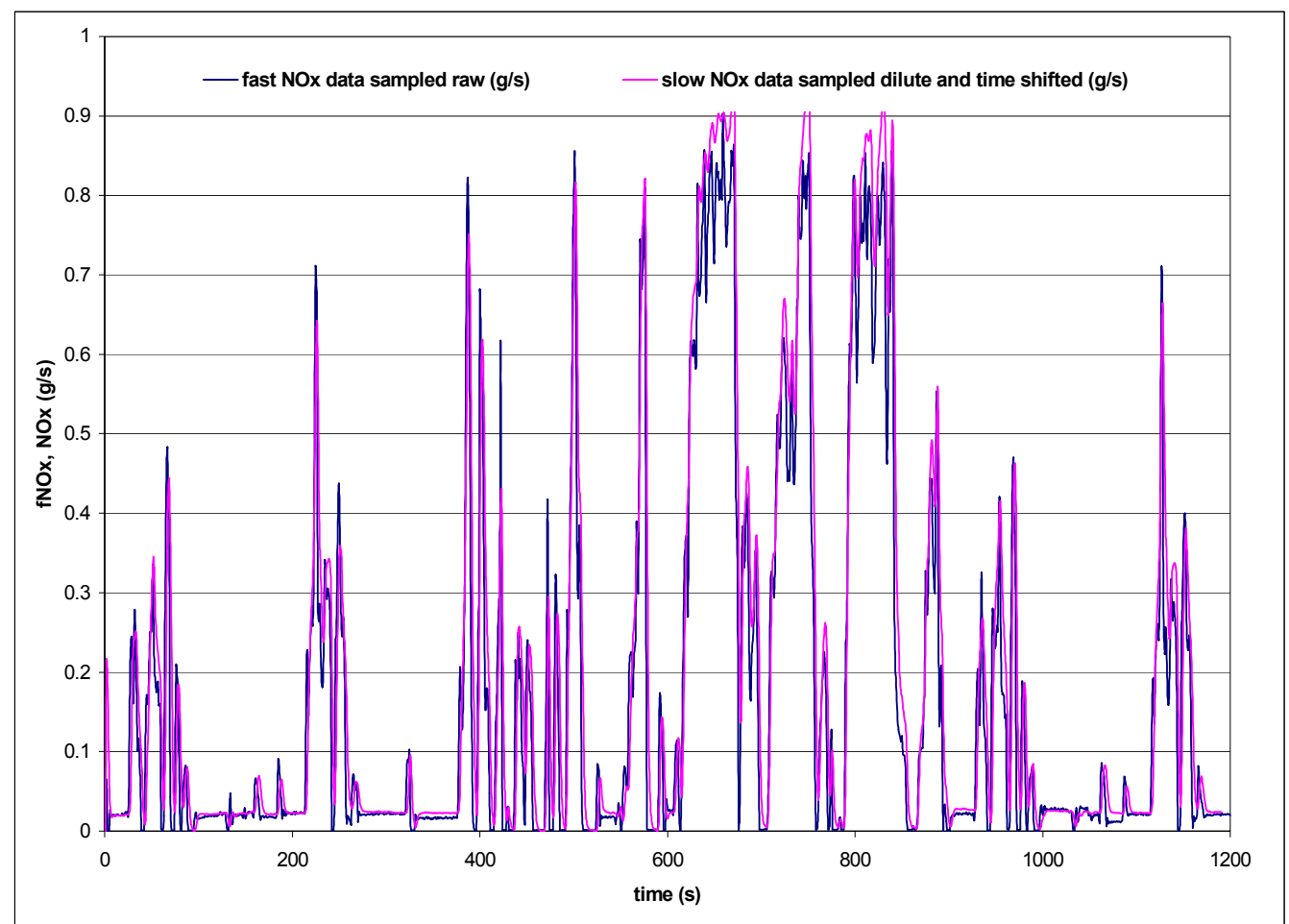

Figure 52 Variation of $\mathrm{NO}_{\mathrm{x}}$ emissions with time for the FTP cycle (with time shifted slow $\mathrm{NO}_{\mathrm{x}}$ data)

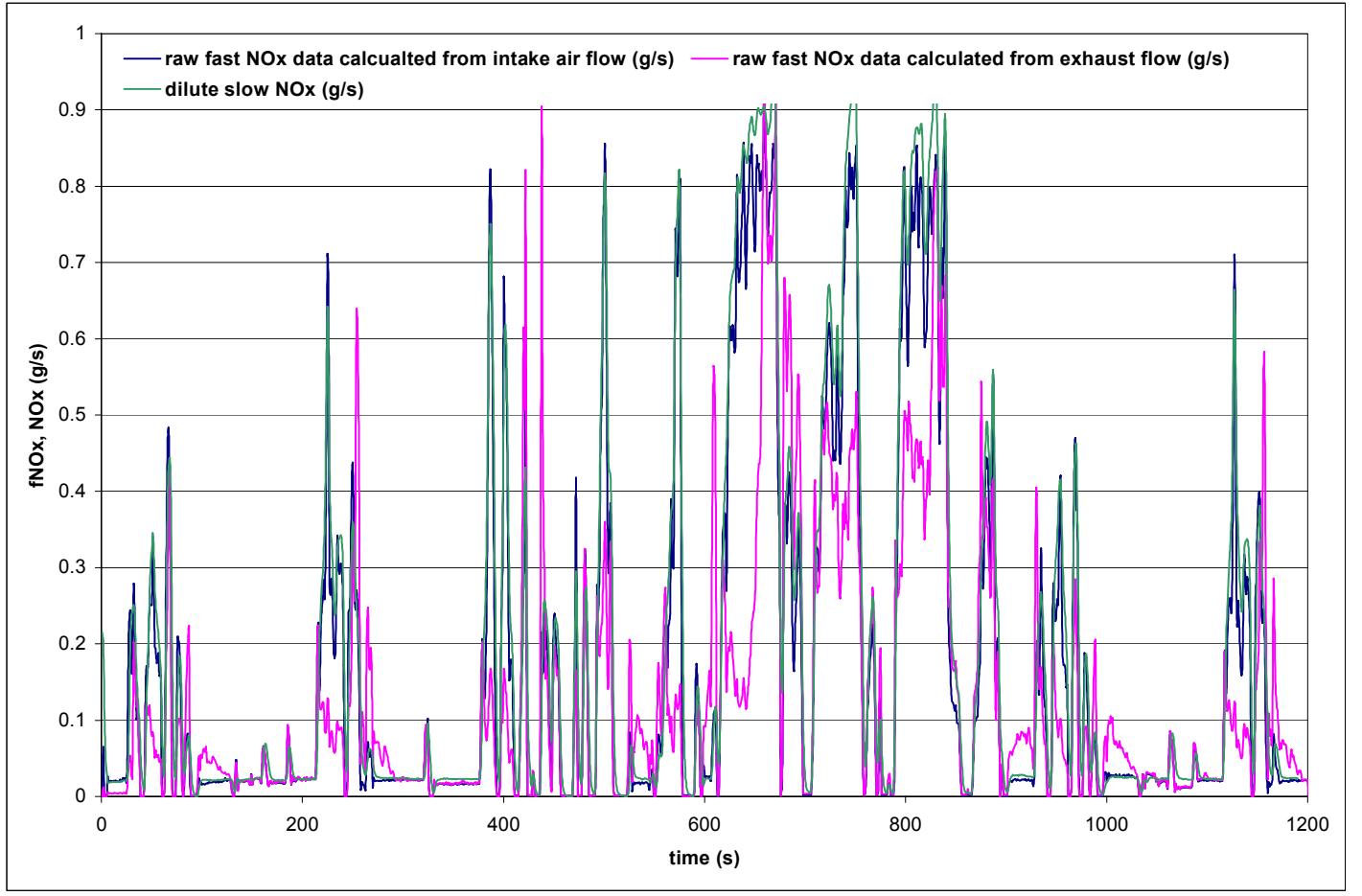

Figure 53 Variation of raw fast $\mathrm{NO}_{\mathrm{x}}$ (calculated using intake air flowrate and exhaust flowrate) with time for the FTP cycle operated on the DDC Series 60 engine. 


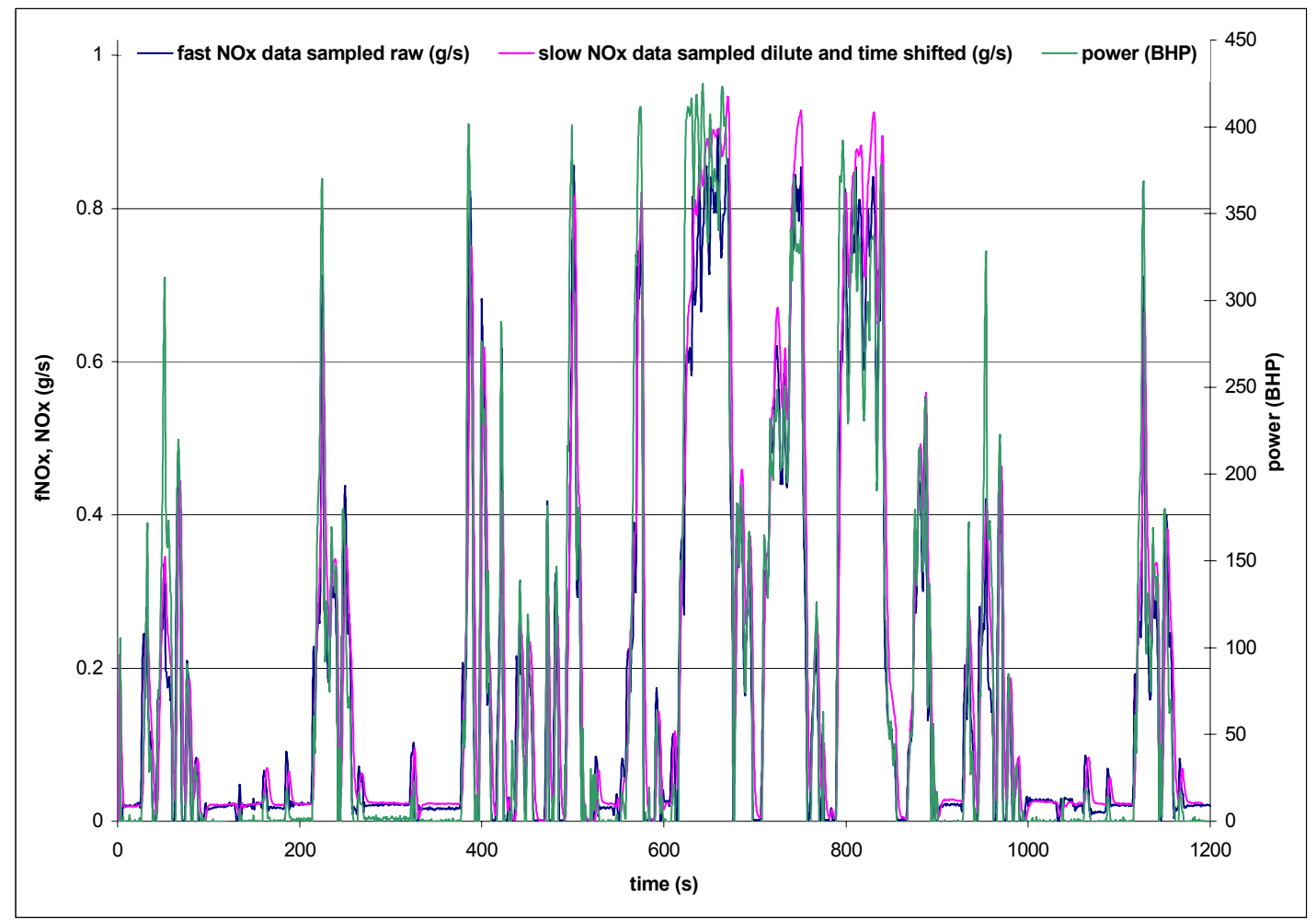

Figure 54 Power and $\mathrm{NO}_{\mathrm{x}}$ emissions with time for the FTP cycle.

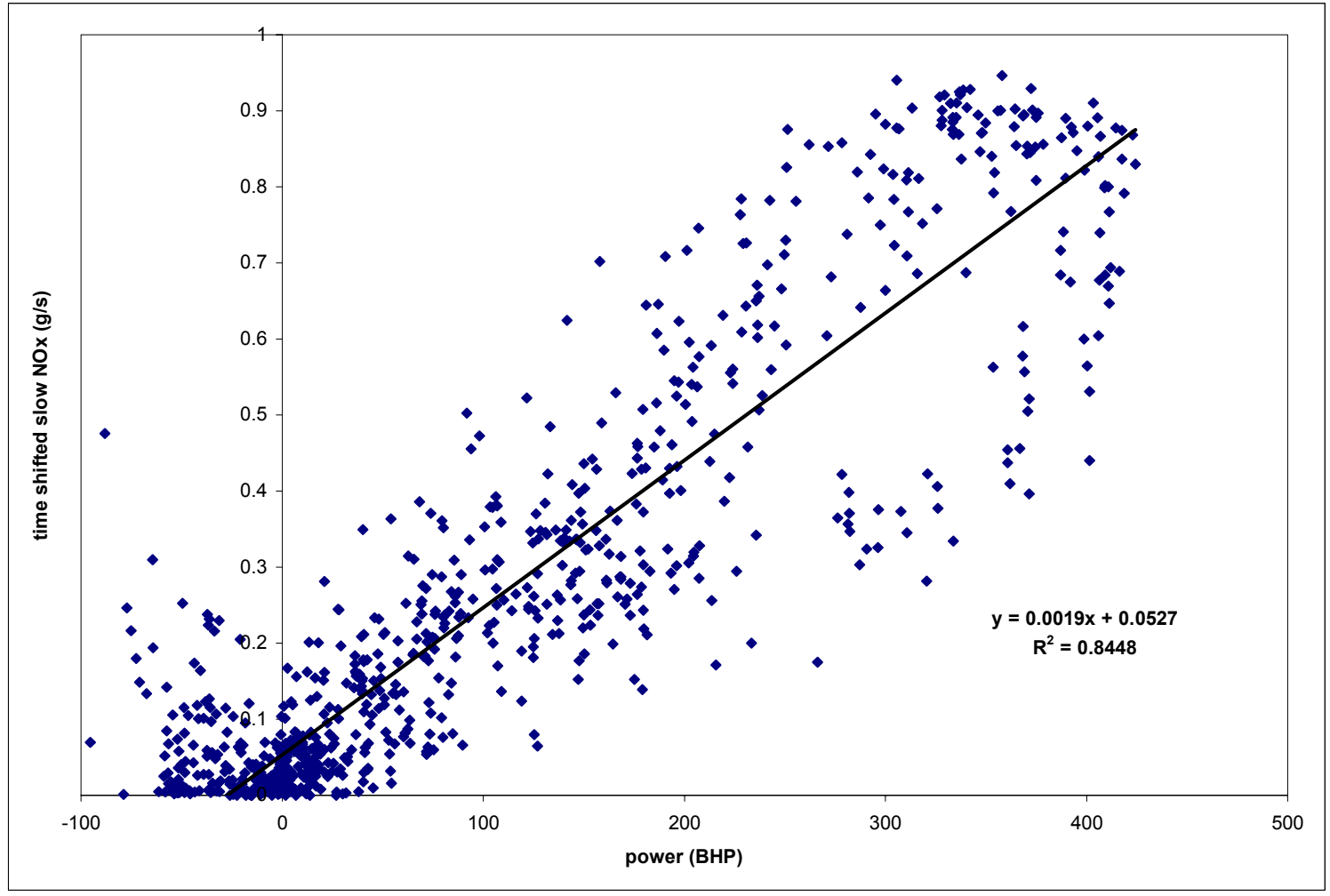

Figure 55 Relation between power and slow $\mathrm{NO}_{\mathrm{x}}$ emission for the FTP cycle. 


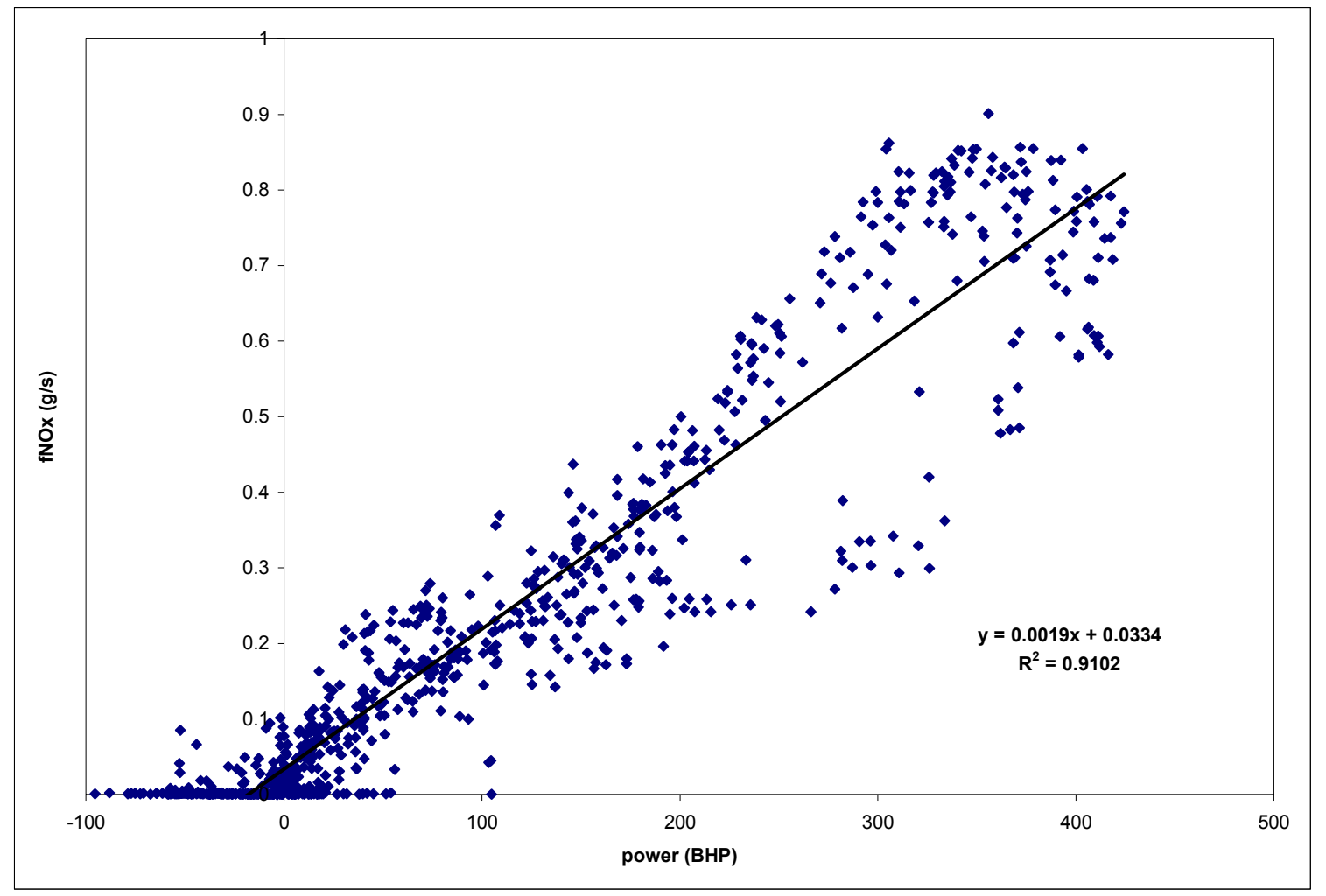

Figure 56 Relation between power and fast NOx emissions for the FTP cycle operated on the DDC Series 60 engine.

\subsection{Tests on Caterpillar Engine, Model Year 1996}

FTP tests were run on the Caterpillar engine. For these FTP cycles raw and dilute samples were measured using the Cambustion fast $\mathrm{NO}_{\mathrm{x}}$ analyzer and dilute samples were measured using the conventional Rosemount analyzer. Concentration (PPM) to mass $(\mathrm{g} / \mathrm{s})$ conversion for the fast $\mathrm{NO}_{\mathrm{x}}$ data was done in two ways a) using the intake airflow rate b) using the exhaust flow rate. Exhaust flow rate was measured using an Annubar placed in the exhaust manifold. Figure 57 shows $\mathrm{NO}_{\mathrm{x}}$ emissions variation with time for a portion of the FTP cycle. This was a hot start cycle. Actual work done during the cycle was $29.55 \mathrm{bhp}-\mathrm{hr}$. Brake specific fuel consumed was $0.376 \mathrm{lb}$./bhp-hr. Figure 58 shows the same with raw $\mathrm{NO}_{\mathrm{x}}$ data calculated from exhaust flow. It is evident that the raw $\mathrm{NO}_{\mathrm{x}}$ data calculated from the exhaust flow rate differs from the raw $\mathrm{NO}_{\mathrm{x}}$ data calculated using the intake airflow. This is because the fuel flowrate is not accounted for and there could also be possible measurement error in the Annubar. The details of Annubar as a flow 
measurement device have been studied by Fuller [29]. The cycle average dilute $\mathrm{NO}_{\mathrm{x}}$ from the fast $\mathrm{NO}_{\mathrm{x}}$ data is $0.056 \mathrm{~g} / \mathrm{s}$ and that from the slow $\mathrm{NO}_{\mathrm{x}}$ data is $0.082 \mathrm{~g} / \mathrm{s}$. Similarly, the cycle average values of the raw fast $\mathrm{NO}_{\mathrm{x}}$ calculated from intake airflow is $0.068 \mathrm{~g} / \mathrm{s}$ and that calculated using the exhaust flow rate is $0.053 \mathrm{~g} / \mathrm{s}$. Brake specific $\mathrm{NO}_{\mathrm{x}}$ emissions for the FTP cycle are $3.33 \mathrm{~g} / \mathrm{bhp}-\mathrm{hr}$. Variation of the emissions and power with time is shown in Figure 59.

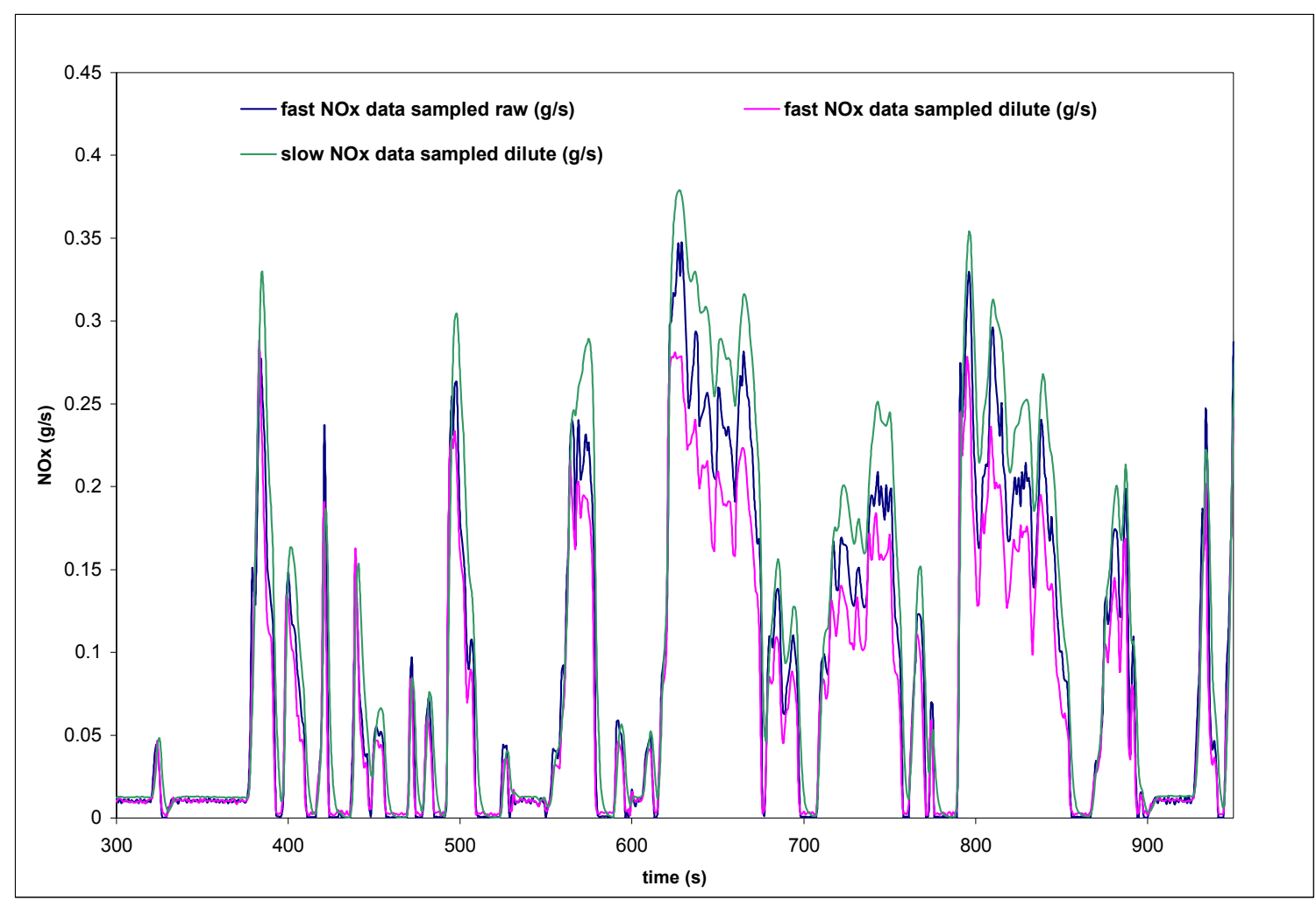

Figure 57 Variation of slow (dilute) and fast (raw and dilute) $\mathrm{NO}_{\mathrm{x}}$ emissions with time for a FTP cycle operated on the Caterpillar engine. 


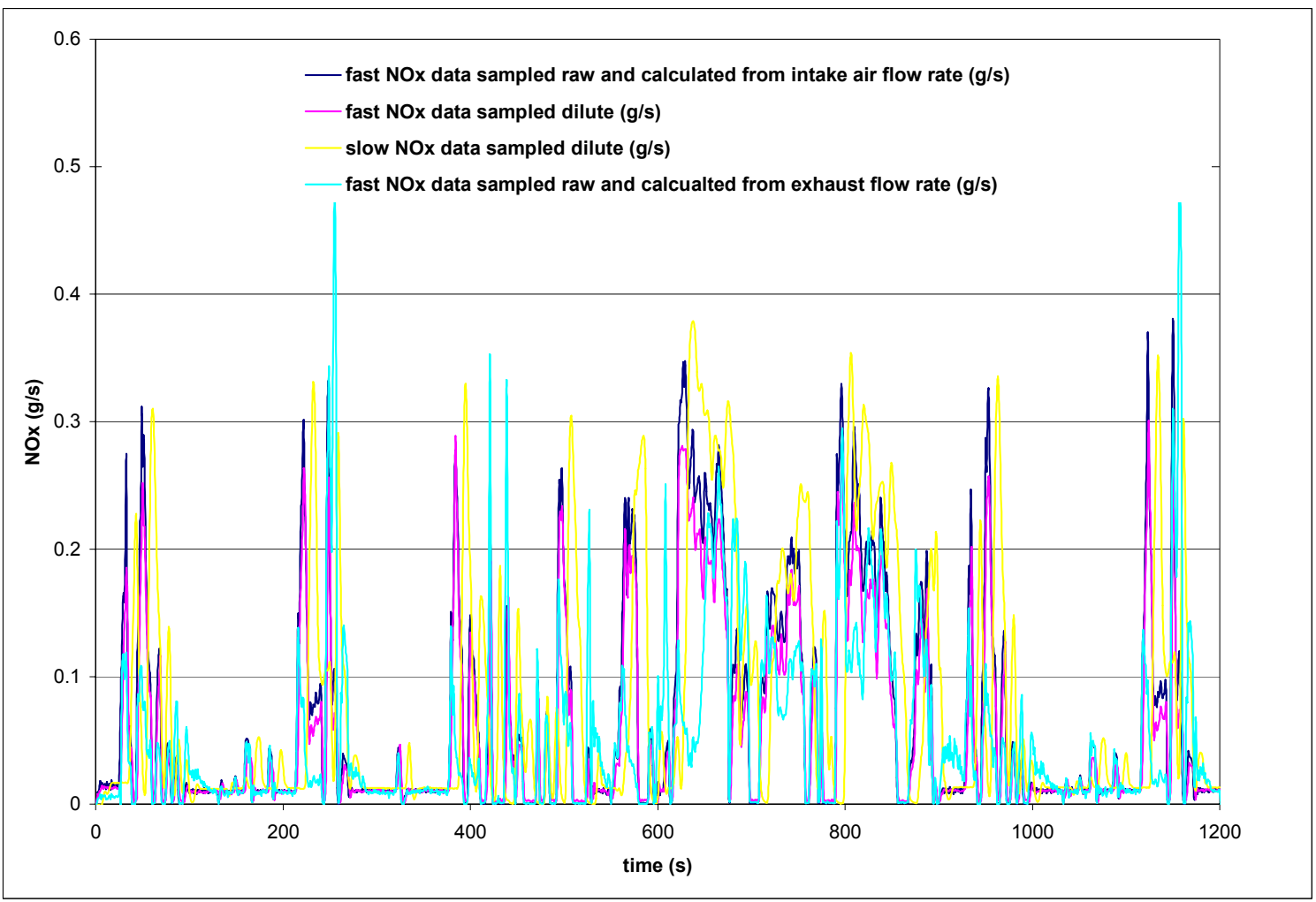

Figure 58 Variation of fast and slow $\mathrm{NO}_{\mathrm{x}}$ emissions with time for a FTP cycle operated on the Caterpillar engine.

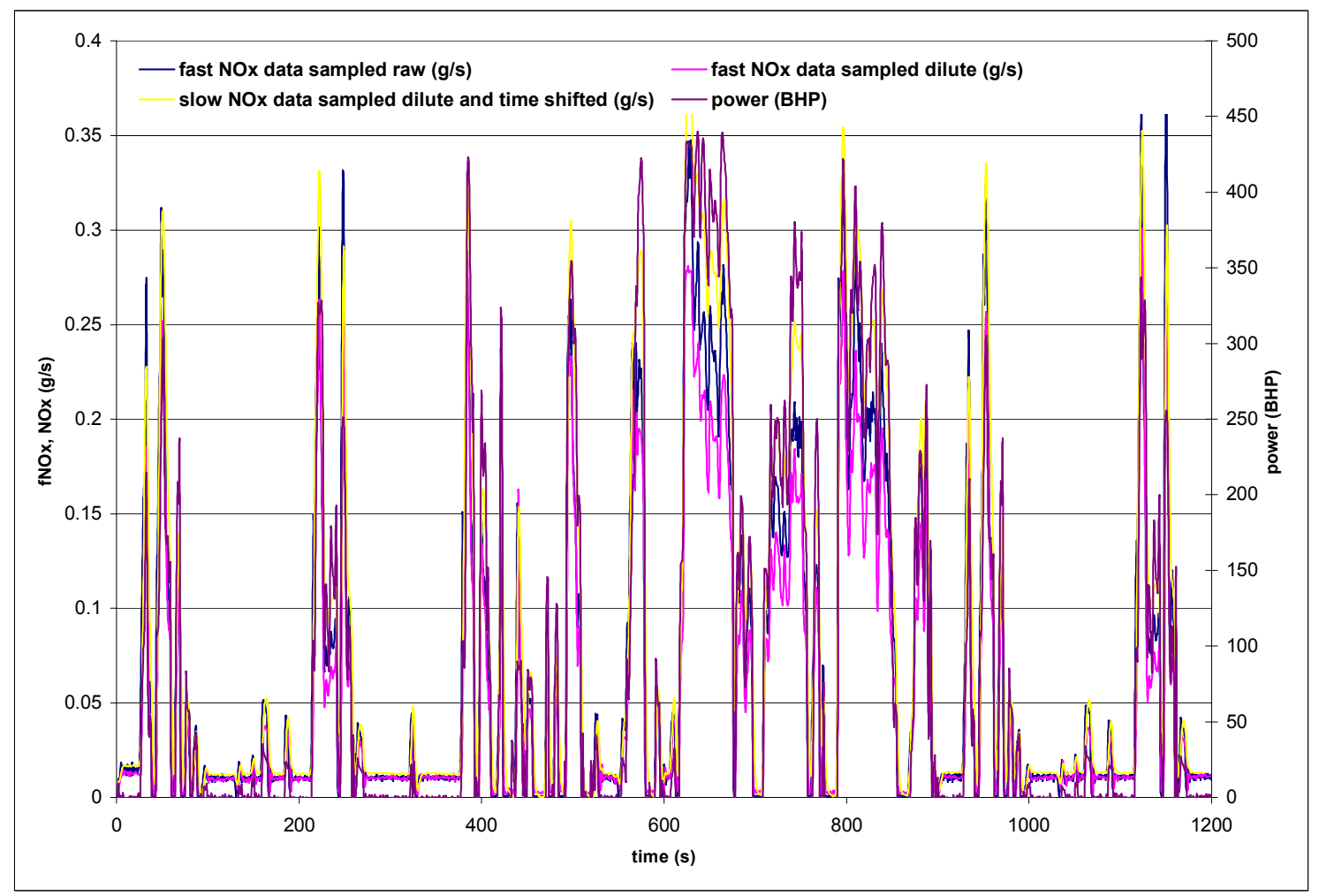

Figure 59 Power and $\mathrm{NO}_{\mathrm{x}}$ emissions with time for the FTP cycle. 


\subsection{Tests on Volvo Engine, Model Year 1998}

FTP tests were conducted on Volvo engine to measure $\mathrm{NO}_{\mathrm{x}}$ using both the analyzers. For the tests on Volvo engine, raw $\mathrm{NO}_{\mathrm{x}}$ samples were taken using the fast $\mathrm{NO}_{\mathrm{x}}$ analyzer and dilute measurements were made using the conventional slow $\mathrm{NO}_{\mathrm{x}}$ analyzer. Data obtained from one of the FTP cycles run on the Volvo engine is considered in this research. Actual work done during the FTP cycle is $26.9 \mathrm{bhp}-\mathrm{hr}$ and the brake specific fuel consumed is $0.407 \mathrm{lb} / \mathrm{bhp}-\mathrm{hr}$. Figure 60 shows the variation of $\mathrm{NO}_{\mathrm{x}}$ emissions with time for the entire FTP cycle performed on the Volvo engine with slow $\mathrm{NO}_{\mathrm{x}}$ data accounted for time delay and shifted. Cycle average $\mathrm{NO}_{\mathrm{x}}$ emissions were $0.081 \mathrm{~g} / \mathrm{s}$ (slow analyzer) and $0.064 \mathrm{~g} / \mathrm{s}$ (fast analyzer). Variation of emissions with power is shown in Figures 61 and 62 . From the $\mathrm{R}^{2}$ values of the two graphs it is evident that the $\mathrm{R}^{2}$ value of $\mathrm{fNO}_{\mathrm{x}}$ and power is higher than the $\mathrm{R}^{2}$ value of slow $\mathrm{NO}_{\mathrm{x}}$ and power. This again proves that the fast $\mathrm{NO}_{\mathrm{x}}$ has a better correlation with power than the slow $\mathrm{NO}_{\mathrm{x}}$.

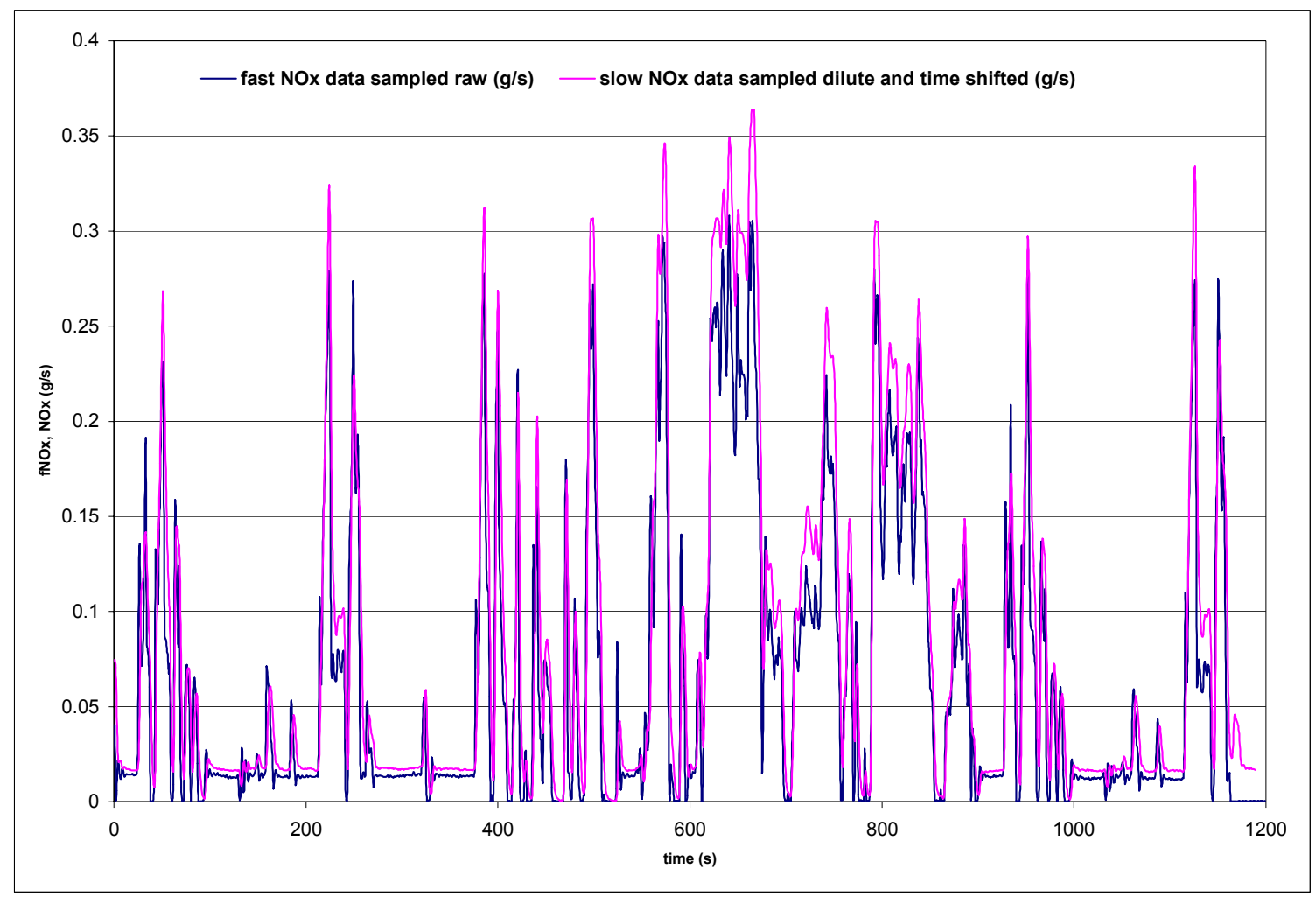


Figure 60 Variation of $\mathrm{NO}_{\mathrm{x}}$ emissions with time for the FTP cycle (slow $\mathrm{NO}_{\mathrm{x}}$ shifted for time) run on the Volvo engine.

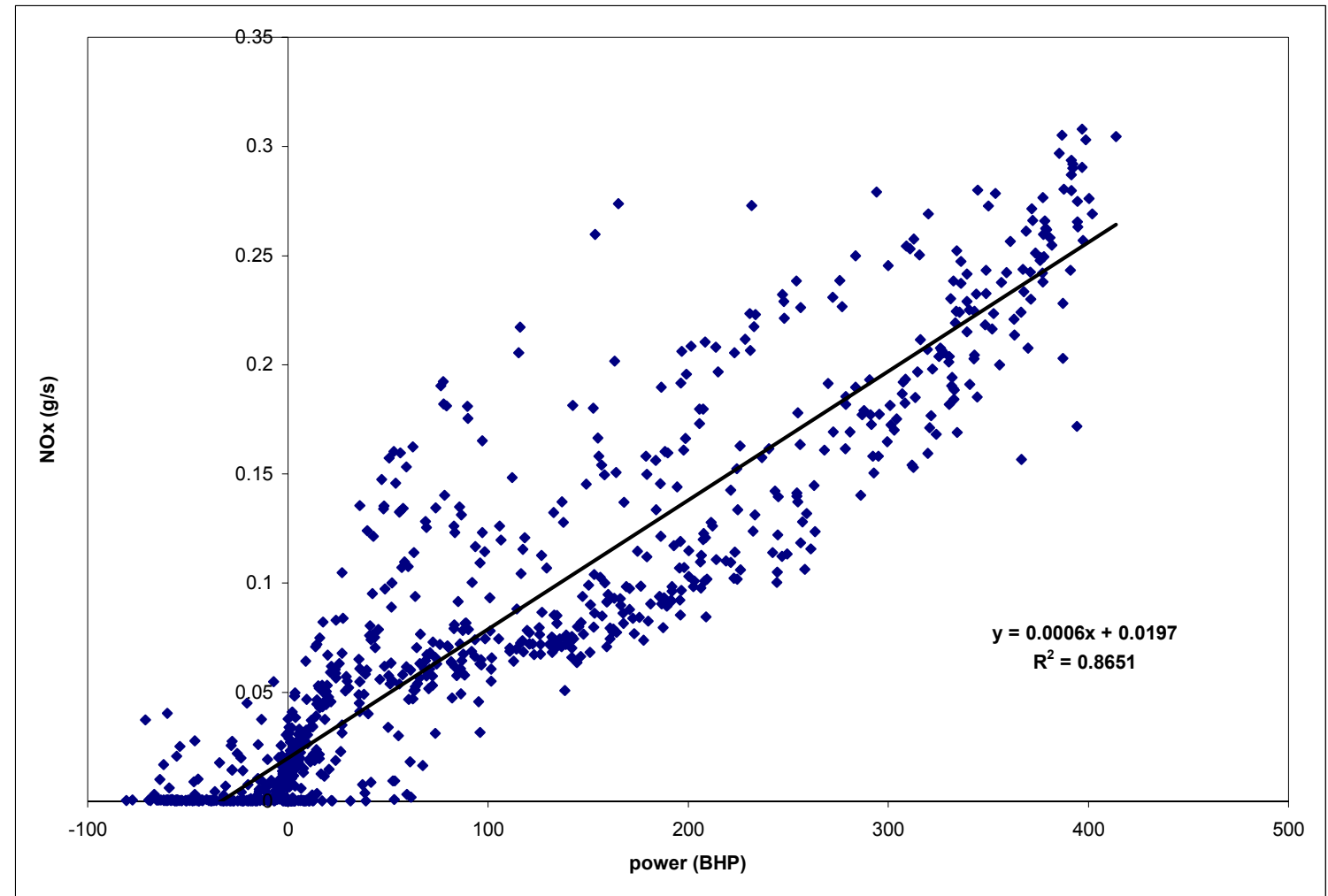

Figure 61 Relation between slow $\mathrm{NO}_{\mathrm{x}}$ and power for the FTP cycle on the Volvo.

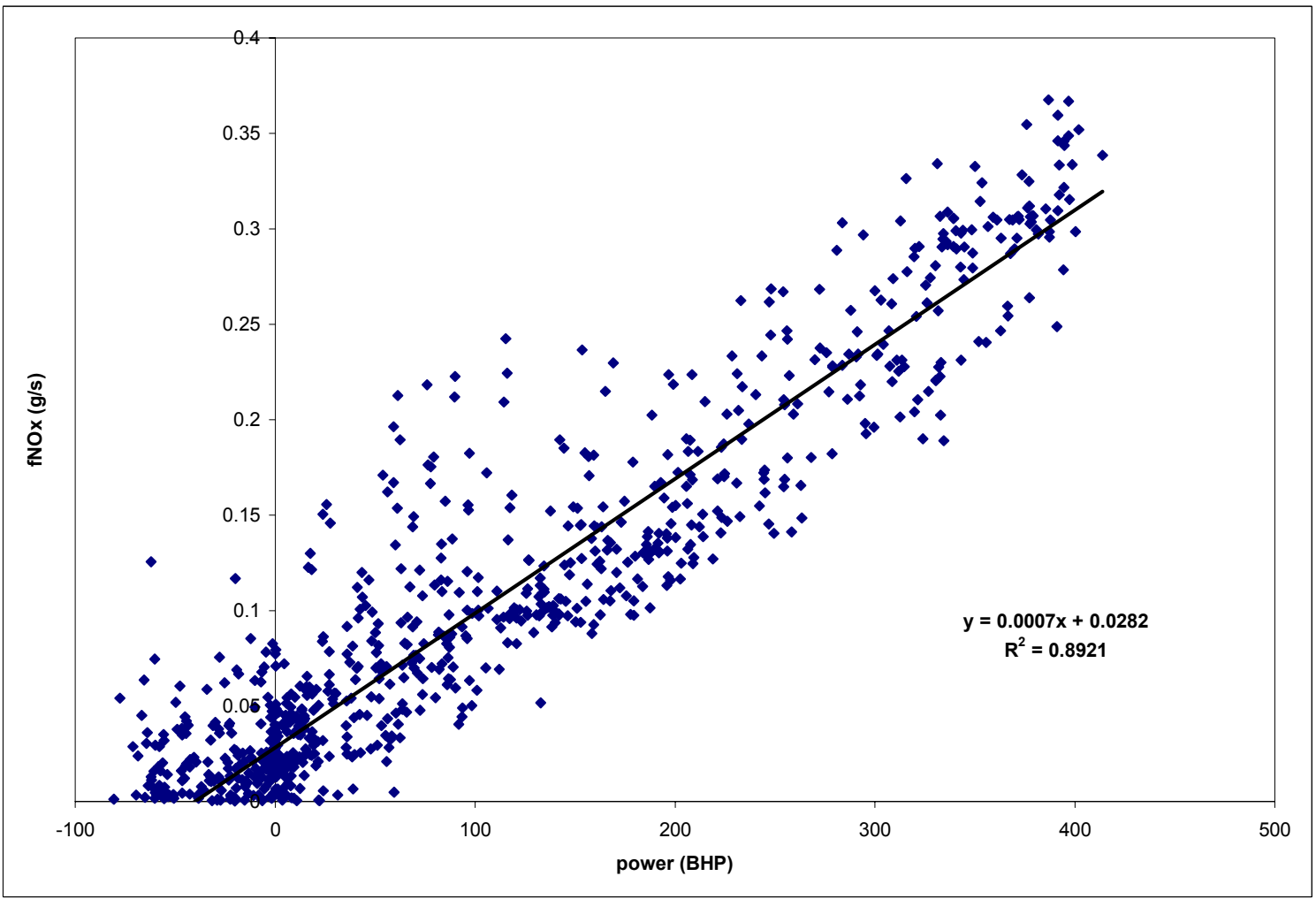

Figure 62 Relation between fast $\mathrm{NO}_{\mathrm{x}}$ and power for the FTP cycle on the Volvo. 


\subsection{Tests on Mack Engine, Model Year 1995}

FTP test cycles run on the Mack engine were hot start cycles. Fast $\mathrm{NO}_{\mathrm{x}}$ analyzer was used to sample both raw and dilute $\mathrm{NO}_{\mathrm{x}}$ emissions. Conventional slow $\mathrm{NO}_{\mathrm{x}}$ analyzer was used to sample dilute $\mathrm{NO}_{\mathrm{x}}$ emissions. Results obtained from one of the FTP test cycles run on the Mack engine are discussed. Actual work done by the cycle is 27.07 bhp-hr and the brake specific fuel consumed is $0.0365 \mathrm{lb}$./bhp-hr. Brake specific $\mathrm{NO}_{\mathrm{x}}$ emissions measured are $4.275 \mathrm{~g} / \mathrm{bhp}-\mathrm{hr}$. Figure 63 shows variation of slow $\mathrm{NO}_{\mathrm{x}}$, fast $\mathrm{NO}_{\mathrm{x}}$ (sampled raw and dilute) with time. Figure 64 shows the variation of dilute fast $\mathrm{NO}_{\mathrm{x}}$ and slow $\mathrm{NO}_{\mathrm{x}}$ with time. The cycle average fast $\mathrm{NO}_{\mathrm{x}}$ emissions obtained from raw sampling are $0.076 \mathrm{~g} / \mathrm{s}$ whereas those obtained from dilute sampling are $0.077 \mathrm{~g} / \mathrm{s}$. The cycle average slow $\mathrm{NO}_{\mathrm{x}}$ emissions are $0.096 \mathrm{~g} / \mathrm{s}$. Variation of $\mathrm{NO}_{\mathrm{x}}$ emissions with power is shown in Figures 65, 66 and 67. The $\mathrm{R}^{2}$ value for the power fit for slow $\mathrm{NO}_{\mathrm{x}}$ is 0.8316 whereas the same for raw fast $\mathrm{NO}_{\mathrm{x}} 0.8968$ and for dilute fast $\mathrm{NO}_{\mathrm{x}}$ is 0.9058 . This increase in $\mathrm{R}^{2}$ value once again shows the better correlation between fast $\mathrm{NO}_{\mathrm{x}}$ and power than slow $\mathrm{NO}_{\mathrm{x}}$ and power. Also from these figures power based fast $\mathrm{NO}_{\mathrm{x}}$ models are obtained by a linear fit between the power and $\mathrm{NO}_{\mathrm{x}}$ data. It is also evident that the change in $\mathrm{R}^{2}$ values in Figures 65 and 66 negligible but there is a considerable difference in $\mathrm{R}^{2}$ values of Figures 65 and 67 . This shows that the diffusion inside the tunnel is negligible and a major portion of diffusion is due to the sampling lines and the analyzer dynamics. 


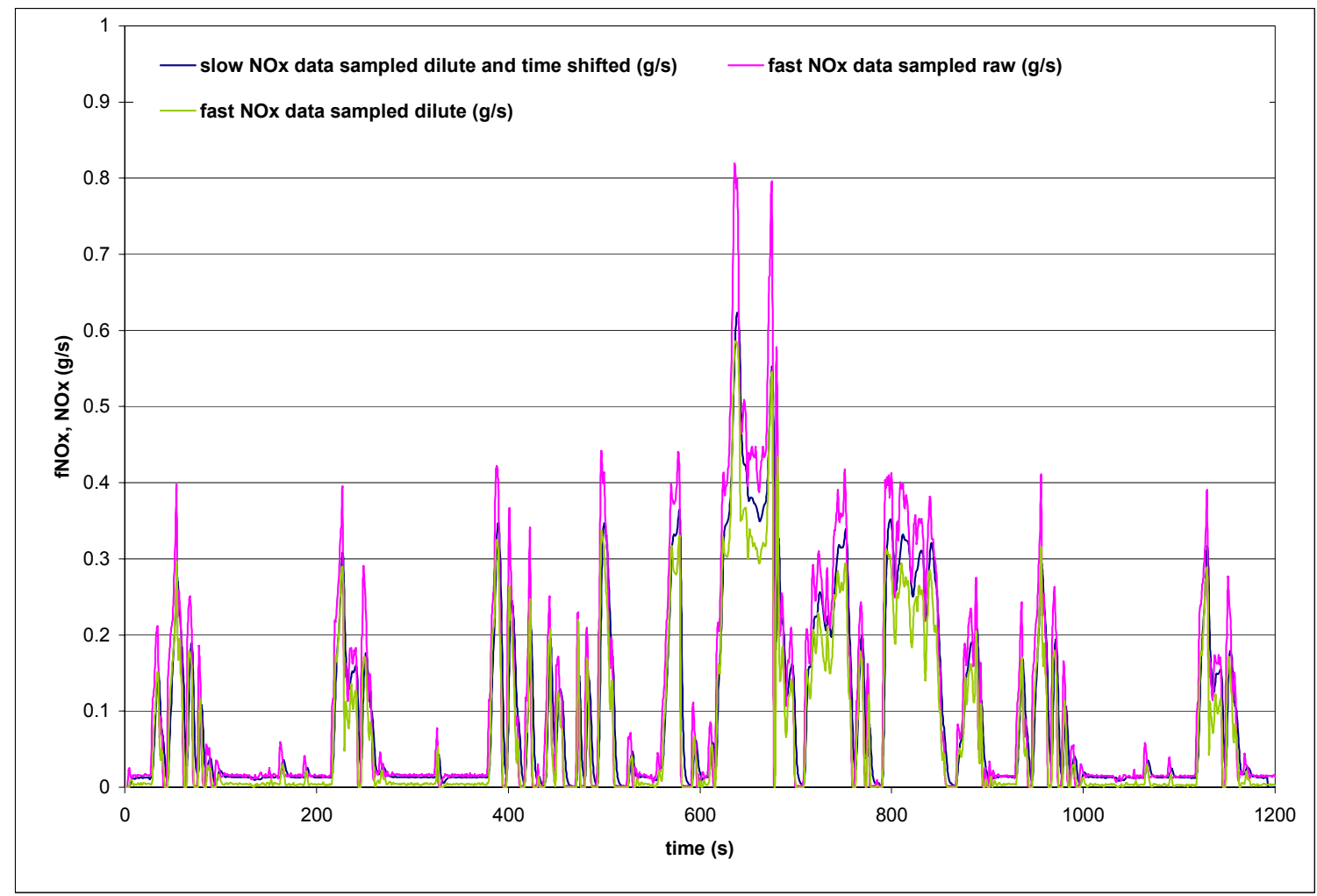

Figure 63 Variation of slow (dilute) and fast (raw and dilute) $\mathrm{NO}_{\mathrm{x}}$ emissions with time for a FTP cycle operated on the Mack truck engine.

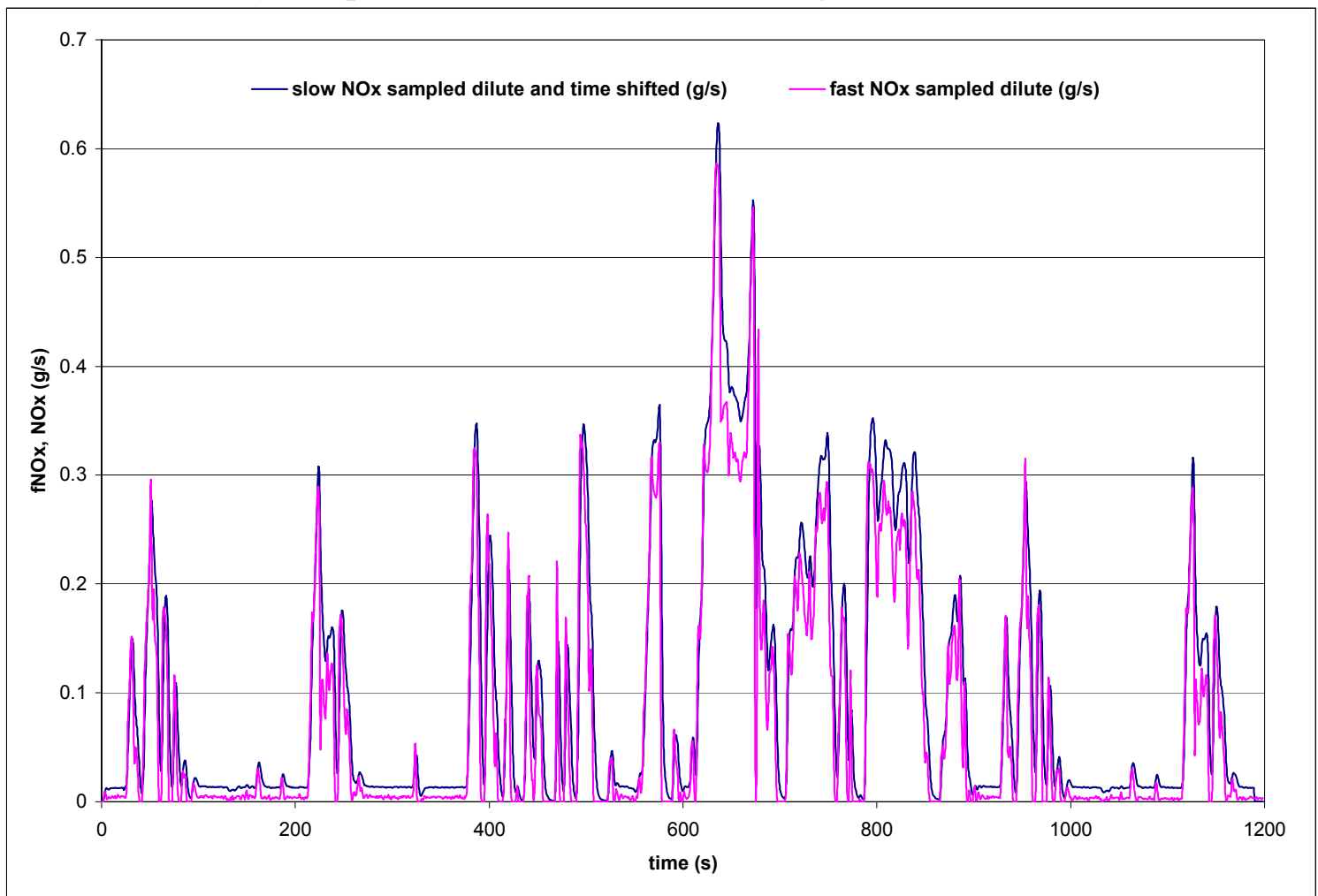

Figure 64 Variation of time shifted slow $\mathrm{NO}_{\mathrm{x}}$ and dilute fast $\mathrm{NO}_{\mathrm{x}}$ for the FTP cycle. 


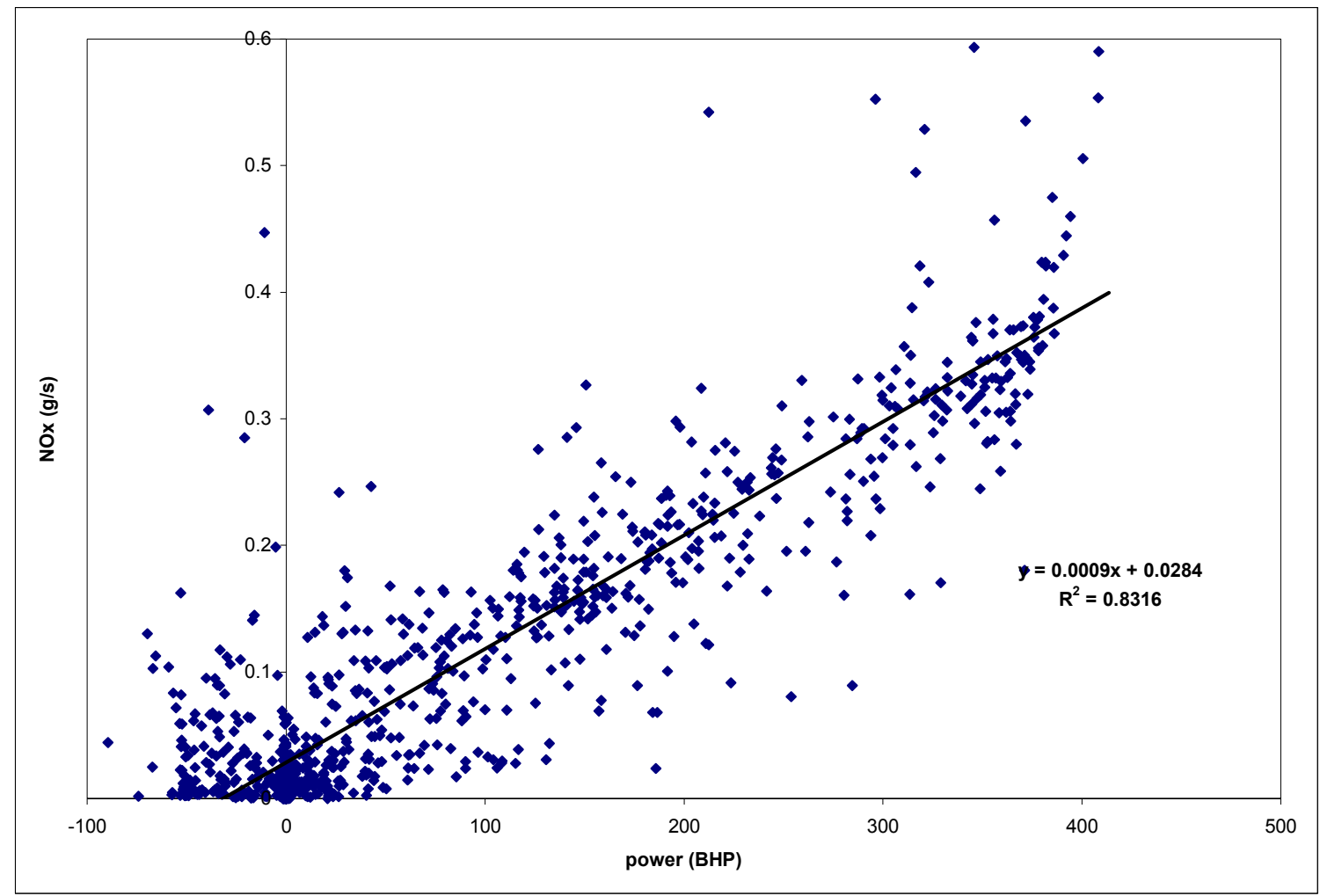

Figure 65 Relation between slow $\mathrm{NO}_{\mathrm{x}}$ and power for an FTP.

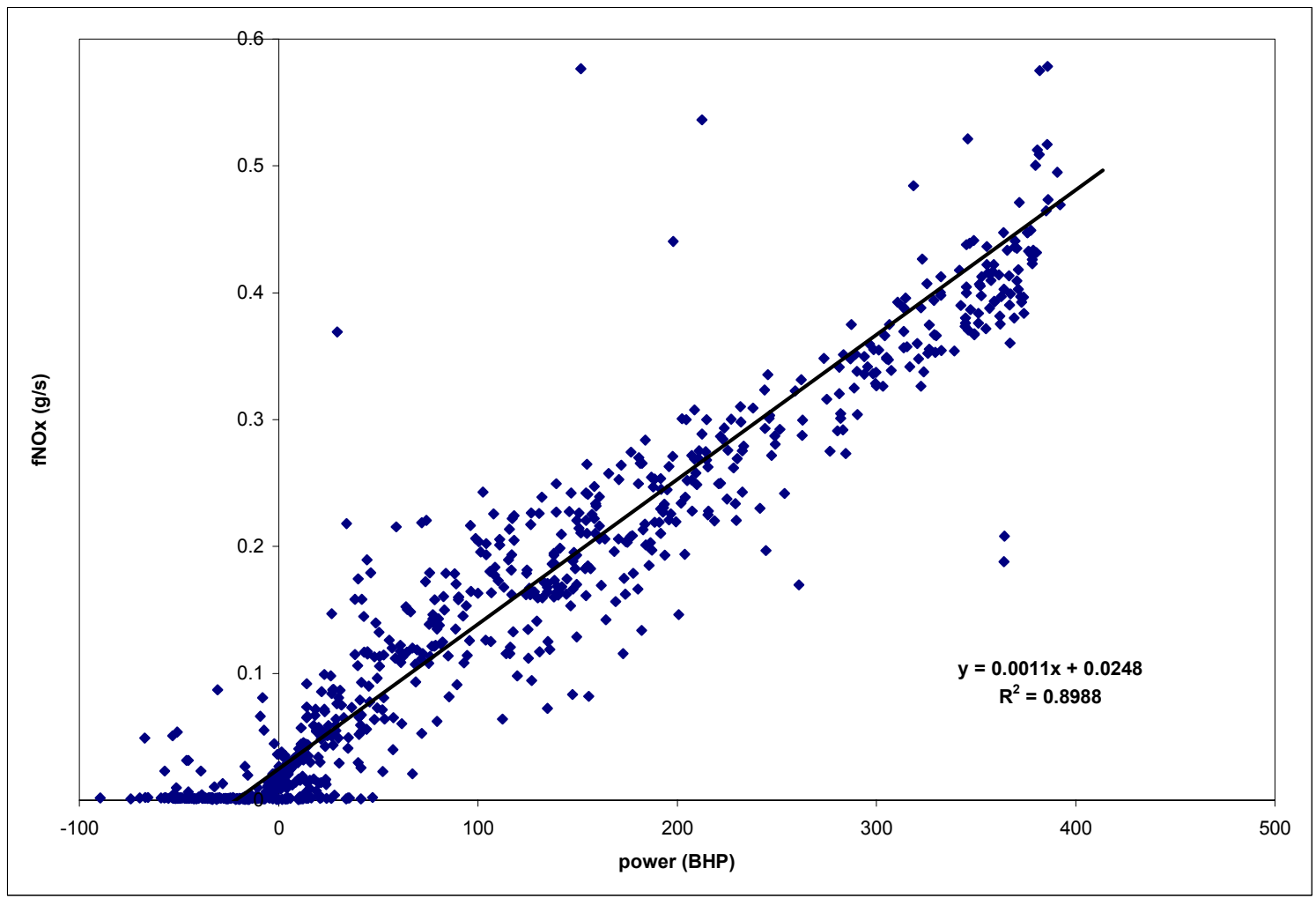

Figure 66 Relation between raw fast $\mathrm{NO}_{\mathrm{x}}$ and power. 


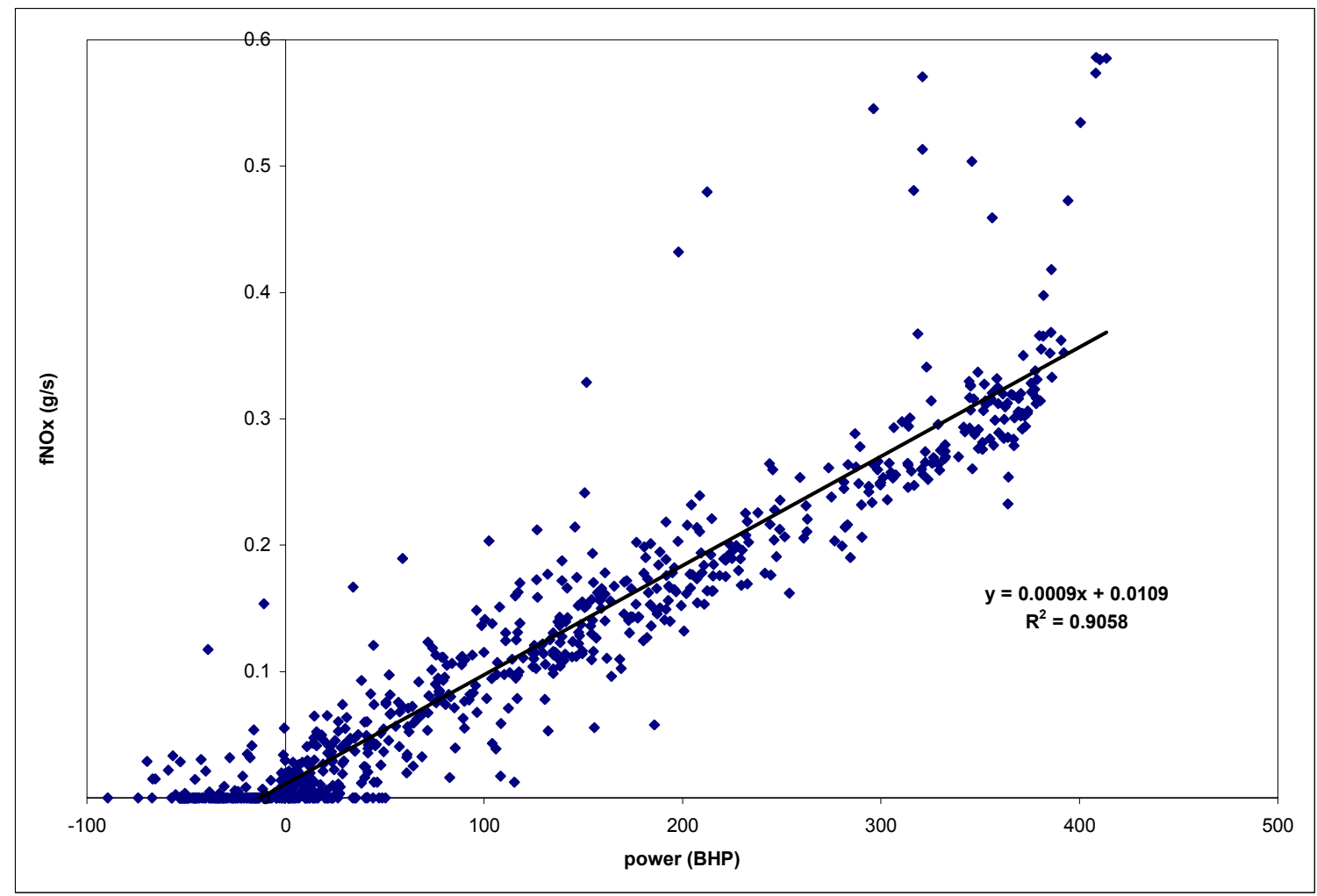

Figure 67 Relation between dilute fast $\mathrm{NO}_{\mathrm{x}}$ and power for a FTP run on the Mack engine.

\subsection{Tests on Navistar Engine, Model Year 1999}

Similar to the other engines, FTP tests were conducted on the Navistar engine. These tests were hot start tests. Fast $\mathrm{NO}_{\mathrm{x}}$ data was sampled for both raw and dilute emissions. Slow $\mathrm{NO}_{\mathrm{x}}$ analyzer sampled dilute data. Actual work done during one of the FTP tests was $14.26 \mathrm{bhp}-\mathrm{hr}$ and the brake specific fuel consumed was $0.427 \mathrm{lb}$./bhp-hr. Brake specific $\mathrm{NO}_{\mathrm{x}}$ emissions obtained were $5.2 \mathrm{~g} / \mathrm{bhp}-\mathrm{hr}$. Variation of $\mathrm{NO}_{\mathrm{x}}$ emissions (both raw and dilute for the fast $\mathrm{NO}_{\mathrm{x}}$ and dilute for the slow $\mathrm{NO}_{\mathrm{x}}$ ) are as shown in Figure 68. Cycle average slow $\mathrm{NO}_{\mathrm{x}}$ emissions are $0.061 \mathrm{~g} / \mathrm{s}$ and cycle average dilute fast $\mathrm{NO}_{\mathrm{x}}$ emissions are $0.051 \mathrm{~g} / \mathrm{s}$. Hence, the dilute slow $\mathrm{NO}_{\mathrm{x}}$ emissions are a bit higher than the dilute fast $\mathrm{NO}_{\mathrm{x}}$ emissions. Cycle average raw fast $\mathrm{NO}_{\mathrm{x}}$ emissions calculated using intake air flowrate are $0.049 \mathrm{~g} / \mathrm{s}$ and those using exhaust flowrate are $0.053 \mathrm{~g} / \mathrm{s}$. There is evidently an increase in $\mathrm{NO}_{\mathrm{x}}$ emissions calculated using the exhaust flow. Variation of 
$\mathrm{NO}_{\mathrm{x}}$ emissions with power is shown in Figures 69 and 70. A higher $\mathrm{R}^{2}$ value for the fast $\mathrm{NO}_{\mathrm{x}}$ and power prove a better correlation than slow $\mathrm{NO}_{\mathrm{x}}$ and power. Fast $\mathrm{NO}_{\mathrm{x}}$ emissions (raw) calculated from intake air and exhausts are plotted with time along with the slow and fast (dilute) $\mathrm{NO}_{\mathrm{x}}$ data in Figure 71.

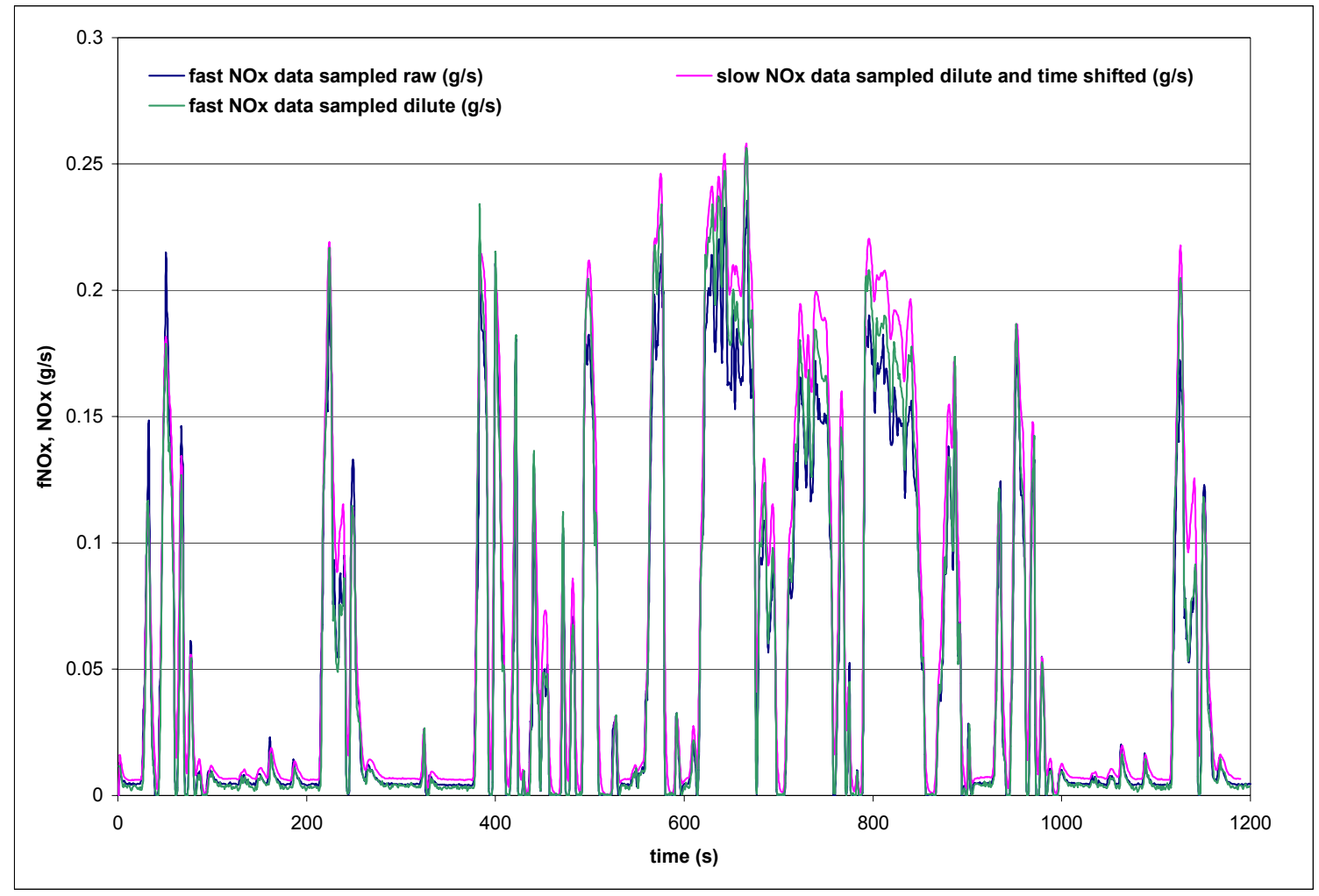

Figure 68 Variation of fast $\mathrm{NO}_{\mathrm{x}}$ (raw and dilute) and slow $\mathrm{NO}_{\mathrm{x}}$ (dilute) with time for a FTP cycle operated on the Navistar engine. 


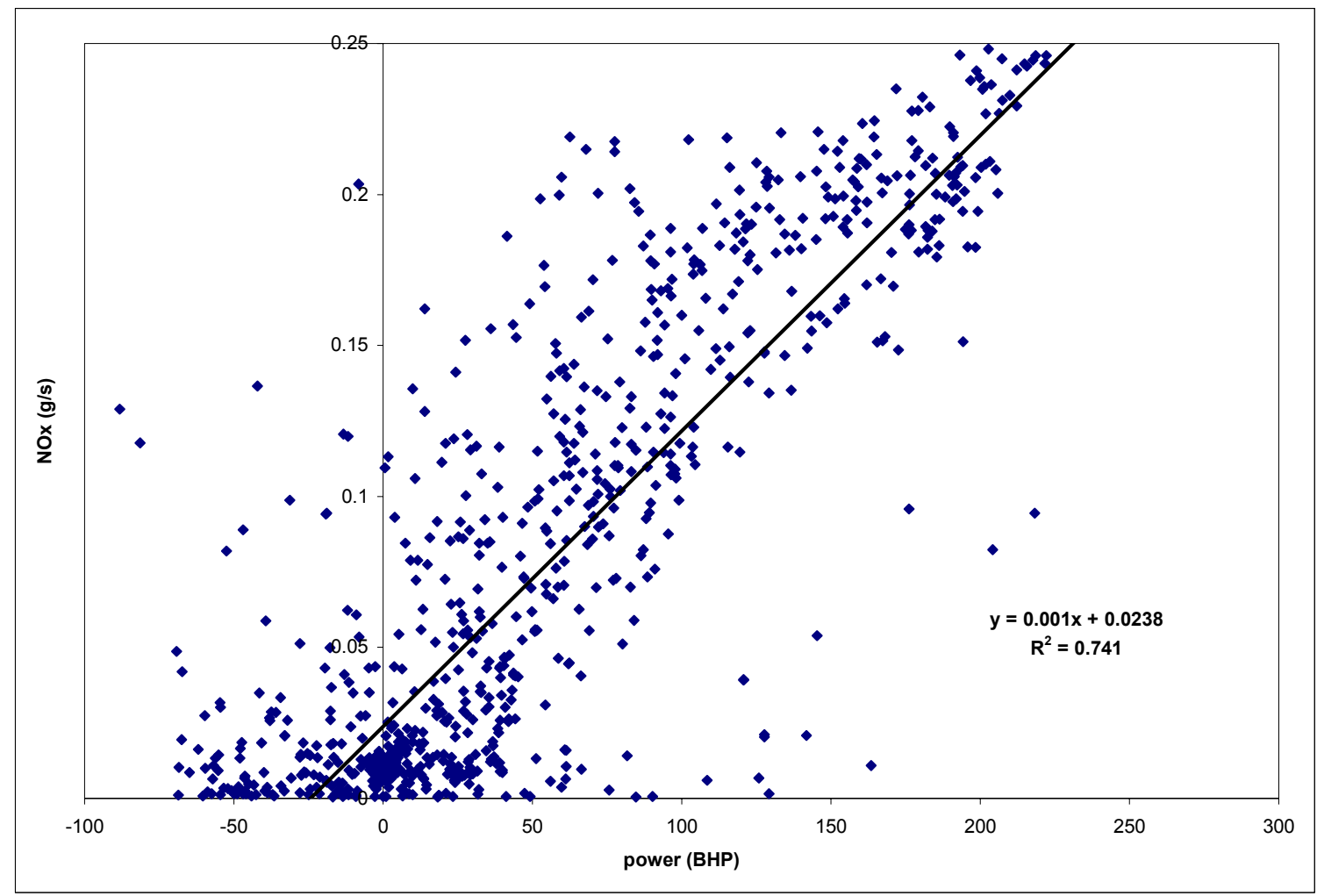

Figure 69 Variation of slow $\mathrm{NO}_{\mathrm{x}}$ data with power for the FTP cycle run on the Navistar engine.

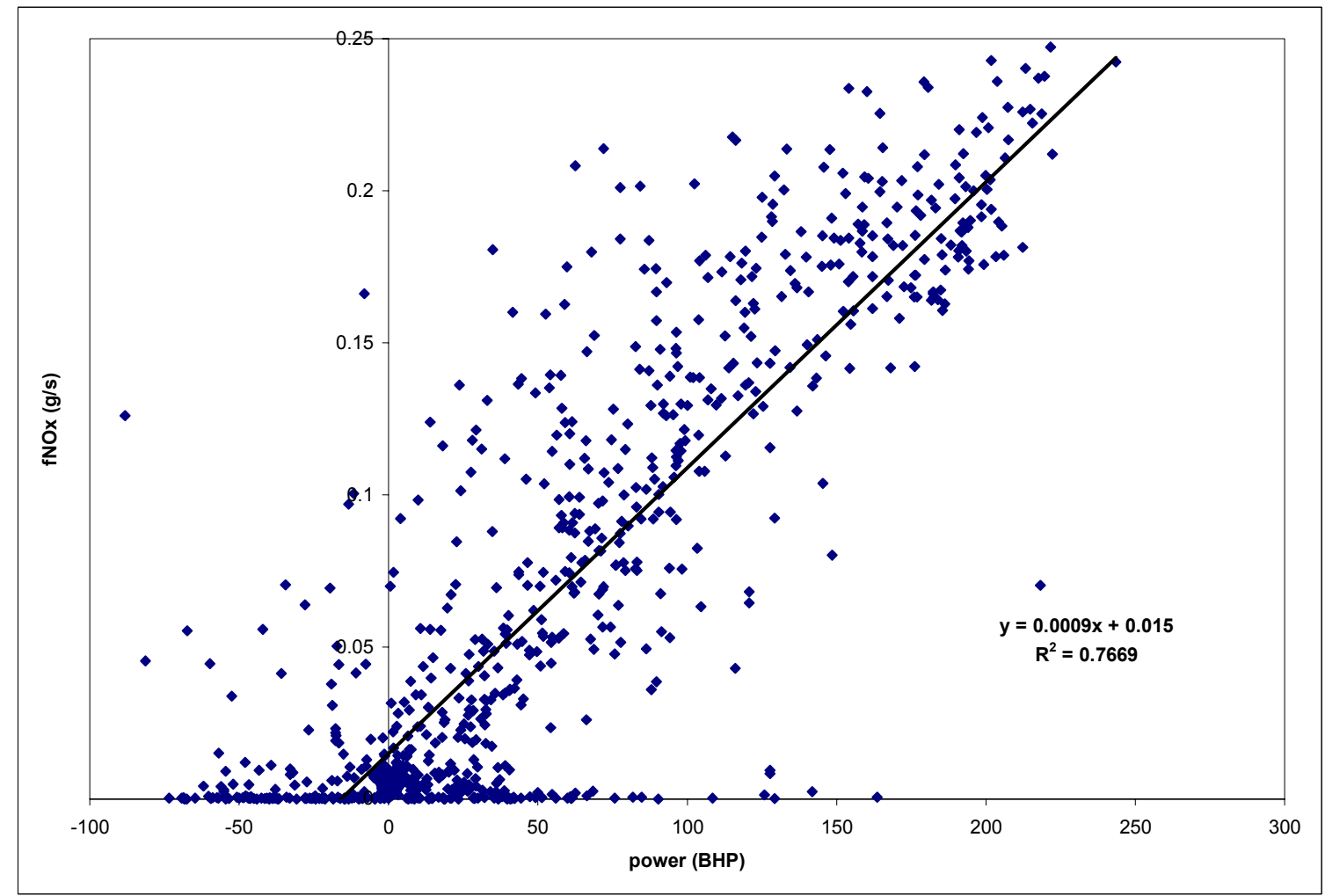

Figure 70 Relation between fast $\mathrm{NO}_{\mathrm{x}}$ and power for the FTP cycle run on the Navistar engine. 


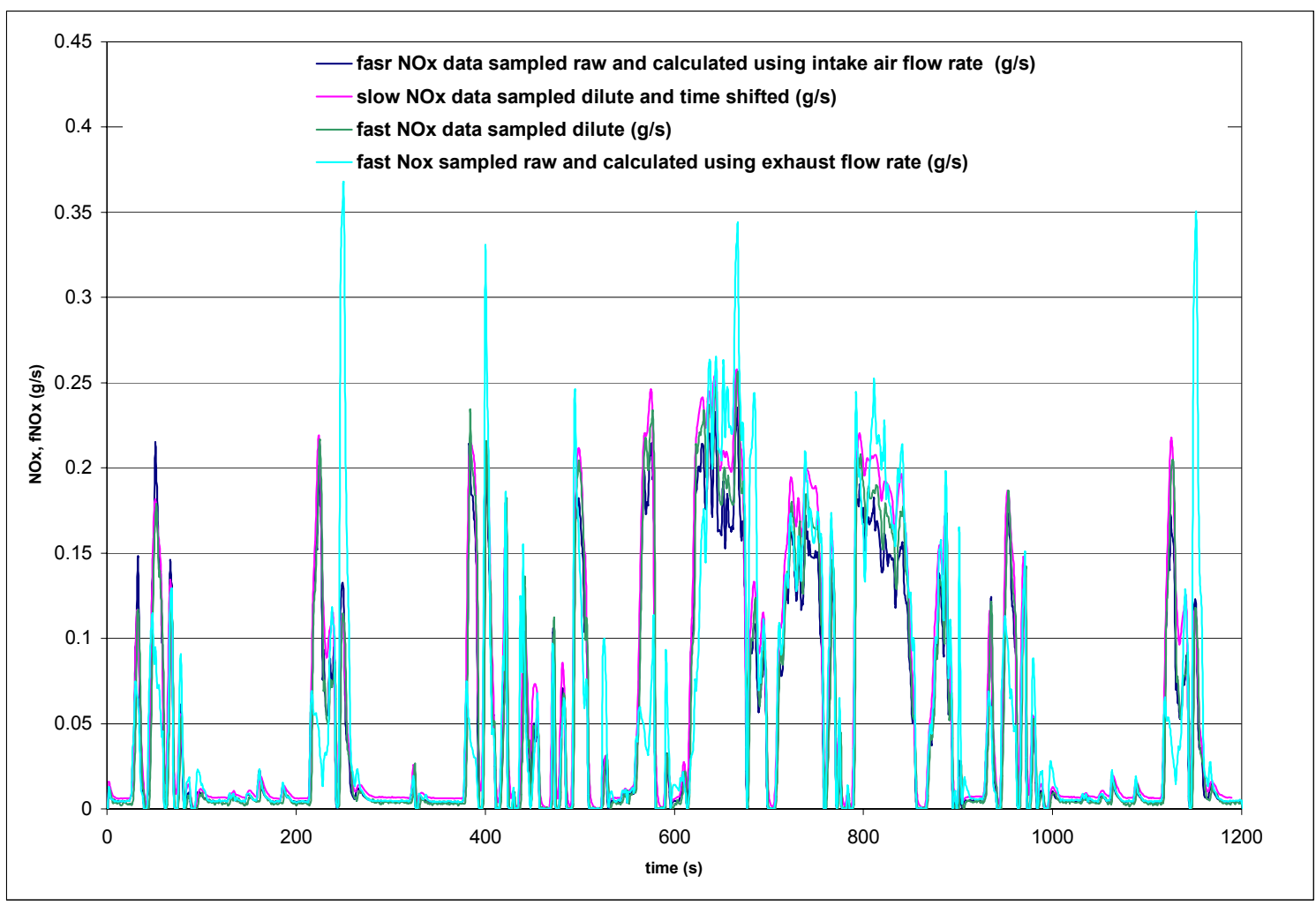

Figure $71 \mathrm{NO}_{\mathrm{x}}$ emissions variation with time for the FTP cycle operated on the Navistar engine.

In general it is noticed that the maximum $\mathrm{NO}_{\mathrm{x}}$ emission values (both slow and fast) differed from engine to engine and so their relation with power. Considering FTP cycle for each of the engines, the slope of the trendline in the plots for power and $\mathrm{NO}_{\mathrm{x}}$ emissions varied between engines and test types [These are shown in the Appendix] because of the magnitude of the measured emissions $(\mathrm{g} / \mathrm{s})$ varied. In general, with increase in transients, the NOx emissions decreased. For more transient tests like CSHVR-E, the maximum slow $\mathrm{NO}_{\mathrm{x}}$ was highest for the DDC Series 60 (Model Year $1995)$ engine $(0.8 \mathrm{~g} / \mathrm{s})$ and was the least for the Navistar (Model Year 99) engine. It is also noticed that the data scatter $\left(\mathrm{NO}_{\mathrm{x}}\right.$ emissions) varied to a considerable amount more for the same FTP cycle between engines. For e.g., the Navistar engine had a lot more data scatter than other engines. This could be due to the engine type. 


\subsection{Inventory Tables for Instantaneous $\mathrm{NO}_{\mathrm{x}}$ Emissions}

Results obtained from different test engines are analyzed so as to know the amount of fast $\mathrm{NO}_{\mathrm{x}}$ emissions from each engine within a certain range of speed and torque. FTP test data from each of the six heavy-duty diesel engines tested is presented in the form of tables. These results form an inventory for the fast $\mathrm{NO}_{\mathrm{x}}$ data. Values in the tables represent the average values of all the points (fast $\mathrm{NO}_{\mathrm{x}}$ emissions in $\mathrm{g} / \mathrm{s}$ ) that lie in the range specified by certain speed and torque conditions. This inventory model provides substantial information of instantaneous emissions that could be useful for further analysis.

Table 11 Fast NO $_{x}$ inventory table for the FTP cycle on the Mack engine

\begin{tabular}{|c|c|c|c|c|c|c|c|c|c|c|}
\hline Speed/Torque & $0.200 \mathrm{Nm}$ & $201400 \mathrm{Nm}$ & $401.600 \mathrm{Nm}$ & $601.800 \mathrm{Nm}$ & $801-1000 \mathrm{Nm} 1$ & $200 \mathrm{Nm}$ & $400 \mathrm{Nm}$ & $00 \mathrm{Nm}$ & $300 \mathrm{Nm}$ & $00 \mathrm{Nm}$ \\
\hline $600.800(\mathrm{RPM})$ & $2.00 \mathrm{E}-02$ & $6.30 \mathrm{E}-02$ & 0.113 & 0.128 & 0 & 0 & 0 & 0 & 0 & 0 \\
\hline $801-1000$ (RPM) & $2.60 \mathrm{E}-02$ & $7.90 \mathrm{E}-02$ & 0.126 & 0.169 & 0.199 & 0 & 0.115 & 0 & 0 & 0 \\
\hline 1001-1200 (RPM) & $3.90 \mathrm{E}-02$ & 0.065 & 0.183 & 0.217 & 0.23 & 0.238 & 0.232 & 0 & 0 & 0 \\
\hline $1201-1400$ (RPM) & 1.10E-02 & 0.093 & 0.146 & 0.197 & 0.236 & 0.278 & 0.303 & 0.311 & 0.407 & 0 \\
\hline 1401-1600 (RPMi) & 4.10E-02 & 0.134 & 0.173 & 0.218 & 0.252 & 0.295 & 0.331 & 0.405 & 0.422 & 0.521 \\
\hline $1601-1800(\mathrm{RPM})$ & 0.061 & 0.104 & 0.153 & 0.184 & 0.246 & 0.292 & 0.355 & 0.412 & 0.53 & 0.786 \\
\hline $1801-2000(\mathrm{RPM})$ & 0.028 & 0.105 & 0.133 & 0.164 & 0.285 & 0.474 & 0.606 & 0 & 0 & 0 \\
\hline
\end{tabular}

Table 12 Fast NO $_{x}$ inventory table for the FTP cycle on the Caterpillar engine

\begin{tabular}{|c|c|c|c|c|c|c|c|c|c|c|}
\hline Speed/Torque & $0.200 \mathrm{Nm}$ & $201400 \mathrm{Nm}$ & $11.600 \mathrm{Nm}$ & $601.800 \mathrm{Nm}$ & $801-1000 \mathrm{Nm}$ & $200 \mathrm{Nm}$ & $400 \mathrm{Nm}$ & $00 \mathrm{Nm}$ & $300 \mathrm{Nm}$ & $00 \mathrm{Nm}$ \\
\hline $600-800(\mathrm{RPM})$ & $1.30 \mathrm{E}-02$ & $3.90 \mathrm{E}-02$ & 0.067 & $9.60 \mathrm{E}-02$ & 0.125 & 0.132 & 0 & 0 & 0 & 0 \\
\hline $801-1000$ (RPM) & 7.00E-03 & $3.70 \mathrm{E}-02$ & 0.0457 & 0.083 & 0.126 & 0.184 & 0.131 & 0 & 0 & 0 \\
\hline $1001-1200$ (RPM) & 0.013 & $1.80 \mathrm{E}-02$ & 0.069 & 0 & 0.181 & 0.225 & 0.238 & 0.256 & 0.304 & 0.285 \\
\hline $1201-1400$ (RPM) & $1.00 \mathrm{E}-03$ & 0.036 & 0 & 0.155 & 0.15 & 0.21 & 0 & 0.272 & 0.282 & 0.299 \\
\hline $1401-1600$ (RPM) & 0.012 & $6.20 \mathrm{E}-02$ & $6.70 \mathrm{E}-02$ & 0.101 & 0.137 & 0.157 & 0.188 & 0.226 & 0.262 & 0.313 \\
\hline $1601-1800$ (RPM) & 1.70E-02 & 0.045 & 0.079 & 0.102 & 0.13 & 0.161 & 0.186 & 0.207 & 0.236 & 0.263 \\
\hline $1801-2000$ (RPM) & 0.042 & $7.80 \mathrm{E}-02$ & $7.60 \mathrm{E}-02$ & $9.00 \mathrm{E}-02$ & 0.117 & 0.153 & 0.167 & 0 & 0 & 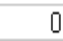 \\
\hline
\end{tabular}

Table 13 Fast NO $_{x}$ inventory table for the FTP cycle on the DDC Series 60 (1995) engine

\begin{tabular}{|c|c|c|c|c|c|c|c|c|c|c|}
\hline Speed/Torque & $0.200 \mathrm{Nm}$ & $201.400 \mathrm{Nm}$ & $401.600 \mathrm{Nm}$ & $601.800 \mathrm{Nm}$ & $801-1000 \mathrm{Nm} 1$ & $1001-1200 \mathrm{Nm} 1$ & $1201-1400 \mathrm{Nm}$ & $000 \mathrm{Nm}$ & $1601-1800 \mathrm{Nm} 1$ & $1801-2000 \mathrm{Nm}$ \\
\hline 600.800 (RPM) & $3.30 \mathrm{E}-02$ & 0.108 & 0.18 & 0.219 & 0 & 0 & 0 & 0 & 0 & 0 \\
\hline $801-1000$ (RPM) & 4.10E-02 & $9.90 E-02$ & 0.2 & 0.2 & 0.286 & 0.418 & 0 & 0 & 0 & 0 \\
\hline $1001-1200$ (RPM) & 0.031 & $7.70 \mathrm{E}-02$ & 0.198 & 0 & 0.242 & 0.289 & 0.337 & 0 & 0 & 0 \\
\hline $1201-1400$ (RPM) & $2.30 \mathrm{E}-02$ & 0.115 & 0.19 & 0.274 & 0.183 & 0.247 & 0.25 & 0.353 & 0.317 & 0.42 \\
\hline $1401-1600$ (RPM) & $7.20 \mathrm{E}-02$ & 0.207 & 0.218 & 0.297 & 0.391 & 0.563 & 0.551 & 0.576 & 0.662 & 0.616 \\
\hline $1601-1800$ (RPM) & $5.10 \mathrm{E}-02$ & 0.14 & 0.222 & 0.312 & 0.472 & 0.609 & 0.764 & 0.793 & 0.753 & 0.753 \\
\hline 1801.2000 (RPM) & 7.40E-02 & 0.16 & 0.228 & 0.325 & 0.523 & 0 & 0 & 0 & 0 & 0 \\
\hline
\end{tabular}


Table 14 Fast NO $_{x}$ inventory table for the FTP cycle on the Volvo engine

\begin{tabular}{|c|c|c|c|c|c|c|c|c|c|c|}
\hline Speed/Torque & $0.200 \mathrm{Nm}$ & $201400 \mathrm{Nm}$ & $01.600 \mathrm{Nm} 6$ & $1.800 \mathrm{Nm}$ & $801-1000 \mathrm{Nm}$ & $1001-1200 \mathrm{Nm}$ & $1201-1400 \mathrm{Nm}$ & $600 \mathrm{Nm}$ & $800 \mathrm{Nm}$ & $000 \mathrm{Nm}$ \\
\hline 600.800 (RPM) & $1.70 \mathrm{E}-02$ & $5.10 \mathrm{E}-02$ & 0.111 & 0.134 & $7.30 \mathrm{E}-02$ & 0 & 0 & 0 & 0 & 0 \\
\hline $801-1000$ (RPM) & $1.60 \mathrm{E}-02$ & $6.80 \mathrm{E}-02$ & 0.137 & 0.118 & 0.148 & 0.259 & 0.231 & 0 & 0 & 0 \\
\hline 1001-1200 (RPM) & $9.00 \mathrm{E}-03$ & $5.40 \mathrm{E}-02$ & 0.124 & 0 & 0.135 & 0.152 & 0.178 & 0.228 & 0 & 0 \\
\hline $1201-1400$ (RPM) & $1.00 \mathrm{E}-02$ & $4.90 \mathrm{E}-02$ & 0.068 & $9.60 \mathrm{E}-02$ & $9.10 \mathrm{E}-02$ & 0.186 & 0.217 & 0.212 & 0.274 & 0.206 \\
\hline $1401-1600$ (RPM) & $2.80 \mathrm{E}-02$ & $6.90 \mathrm{E}-02$ & $9.00 \mathrm{E}-02$ & 0.102 & 0.104 & 0.146 & 0.212 & 0.226 & 0.246 & 0 \\
\hline $1601-1800$ (RPM) & $3.40 \mathrm{E}-02$ & $4.60 \mathrm{E}-02$ & $7.00 \mathrm{E}-02$ & $8.80 \mathrm{E}-02$ & 0.108 & 0.144 & 0.184 & 0.217 & 0.275 & 0 \\
\hline $1801-2000$ (RPM) & $3.40 \mathrm{E}-02$ & $6.10 \mathrm{E}-02$ & $7.60 \mathrm{E}-02$ & $9.10 \mathrm{E}-02$ & 0.134 & 0.166 & 0 & 0 & 0 & 0 \\
\hline
\end{tabular}

Table 15 Fast NO $_{x}$ inventory table for the FTP cycle on the Navistar engine

\begin{tabular}{|l|r|r|r|r|r|}
\hline Speed/Torque & 0-200 Nm & $\mathbf{2 0 1} \mathbf{4 0 0} \mathbf{~ N m}$ & $\mathbf{4 0 1} \mathbf{6 0 0} \mathbf{~ N m}$ & $\mathbf{6 0 1 - 8 0 0 ~} \mathbf{~ m}$ \\
\hline $\mathbf{6 0 0 - 8 0 0}$ (RPM) & 0 & $2.00 \mathrm{E}-02$ & 0 & 0 \\
\hline $\mathbf{8 0 1 - 1 0 0 0}$ (RPM) & $3.90 \mathrm{E}-02$ & 0.038 & 0 & 0 \\
\hline $\mathbf{1 0 0 1 - 1 2 0 0}$ (RPM) & $1.30 \mathrm{E}-02$ & 0.028 & 0.091 & 0 \\
\hline $\mathbf{1 2 0 1 - 1 4 0 0}$ (RPM) & 0.051 & 0.035 & 0.102 & 0 \\
\hline $\mathbf{1 4 0 1 - 1 6 0 0}$ (RPM) & 0.038 & 0.085 & 0.131 & 0 \\
\hline $\mathbf{1 6 0 1 - 1 8 0 0}$ (RPM) & $2.40 \mathrm{E}-02$ & 0.143 & 0.176 & 0 \\
\hline $\mathbf{1 8 0 1 - 2 0 0 0}$ (RPM) & $3.90 \mathrm{E}-02$ & 0.103 & 0.142 & 0 \\
\hline $\mathbf{2 0 0 1 - 2 2 0 0}$ (RPM) & 0.041 & 0.119 & 0.179 & 0.198 \\
\hline $\mathbf{2 2 0 1 - 2 4 0 0}$ (RPM) & 0.052 & 0.113 & 0.167 & 0.208 \\
\hline $\mathbf{2 4 0 1 - 2 6 0 0}$ (RPM) & $4.40 \mathrm{E}-02$ & 0.112 & 0.152 & 0.206 \\
\hline $\mathbf{2 6 0 1 - 2 8 0 0}$ (RPM) & $5.90 \mathrm{E}-02$ & $8.20 \mathrm{E}-02$ & 0.128 & 0 \\
\hline
\end{tabular}

Table 16 Fast $\mathrm{NO}_{\mathrm{x}}$ inventory table for the FTP cycle on the DDC Series 60 (2000) engine

\begin{tabular}{|c|c|c|c|c|c|c|c|c|c|c|}
\hline Speed/Torque & $0.200 \mathrm{Nm}$ & $201400 \mathrm{Nm}$ & $000 \mathrm{Nm}$ & $800 \mathrm{Nm}$ & $0 \mathrm{Nm}$ & $00 \mathrm{Nm}$ & $100 \mathrm{Nm}$ & $00 \mathrm{Nm}$ & $00 \mathrm{Nm}$ & $\mathrm{Nm}$ \\
\hline 600.800 (RPM) & $1.90 \mathrm{E}-02$ & 0.082 & 0.106 & 0.12 & 0 & 0 & 0 & 0 & 0 & \\
\hline $801-1000(\mathrm{RPM})$ & $2.50 \mathrm{E}-02$ & $5.30 \mathrm{E}-02$ & $9.40 \mathrm{E}-02$ & 0.09 & 0 & 0 & 0 & 0.192 & 0 & \\
\hline $1001-1200$ (RPM) & 0.036 & 0.058 & 0.109 & 0.15 & 0.173 & 0.188 & 0.201 & 0.209 & 0 & \\
\hline $1201-1400$ (RPM) & 0.004 & 0 & 0.125 & 0.147 & 0.15 & 0.181 & 0.215 & 0.256 & 0 & \\
\hline $1401-1600(\mathrm{RPM})$ & $0.00 \mathrm{E}+00$ & 2.10E-02 & 0.07 & 0.101 & 0.138 & 0.184 & 0.198 & 0.289 & 0.3 & 0.308 \\
\hline $1601-1800$ (RPM) & $0.00 \mathrm{E}+00$ & $5.20 \mathrm{E}-02$ & 0.096 & 0.129 & 0.139 & 0.159 & 0.179 & 0.259 & 0.293 & 0.3 \\
\hline $1801-2000$ (RPM) & 0.0118329 & $5.50 \mathrm{E}-02$ & $6.80 \mathrm{E}-02$ & 0.118 & 0.13 & 0.152 & 0.181 & 0.229 & 0.289 & 0.33 \\
\hline $2001-2200(\mathrm{RPM})$ & $3.60 \mathrm{E}-02$ & 0.047 & $7.50 \mathrm{E}-02$ & $9.30 \mathrm{E}-02$ & 0.102 & 0.157 & 0.197 & 0.222 & 0.237 & \\
\hline $2201-2400$ (RPM) & 0.003 & 0 & 0 & 0 & 0 & 0 & 0 & 0 & 0 & \\
\hline
\end{tabular}

\subsection{Instantaneous NO prediction models}

\subsubsection{Fast NOx Models for the FTP Cycle}

$\mathrm{NO}_{\mathrm{x}}$ data obtained from FTP cycles operated on different heavy-duty diesel engines was used to predict raw instantaneous emissions. $\mathrm{NO}_{\mathrm{x}}$ data was measured using the Cambustion fast NOx analyzer. For each of the engines, power based fast $\mathrm{NO}_{\mathrm{x}}$ prediction model was established using a linear fit between power and raw fast $\mathrm{NO}_{\mathrm{x}}$ emissions. A universal raw $\mathrm{NO}_{\mathrm{x}}$ prediction model was then deduced averaging the coefficients in the previous models. Universal model for instantaneous $\mathrm{NO}_{\mathrm{x}}$ prediction for any heavy-duty diesel engine for an FTP cycle is given by Equation 11 

$\left(N O_{x}\right)=0.00074521$
$*\left(\begin{array}{ll}\text { BHP } & )+0.021\end{array}\right.$
Equation 11

Where $\mathrm{NO}_{\mathrm{x}}$ denotes the instantaneous $\mathrm{NO}_{\mathrm{x}}$ emissions in $\mathrm{g} / \mathrm{s}$ and $\mathrm{BHP}$ is the engine brake horsepower. This universal $\mathrm{NO}_{\mathrm{x}}$ prediction model for the FTP cycle was then used to predict the $\mathrm{NO}_{\mathrm{x}}$ emissions from different heavy-duty diesel engines. It could predict the values with an error of $0-20 \%$.The results obtained are in table below.

Table 17 Instantaneous NOx emissions prediction for the FTP cycle

\begin{tabular}{|l|l|l|l|}
\hline Engine & $\begin{array}{l}\text { Experimental Fast } \mathrm{NO}_{\mathrm{x}} \\
\text { Cycle Integrated }(\mathrm{g} / \mathrm{s})\end{array}$ & $\begin{array}{l}\text { Fast } \mathrm{NO}_{\mathrm{x}} \text { predicted } \\
\text { Cycle Integrated }(\mathrm{g} / \mathrm{s})\end{array}$ & $\%$ error \\
\hline DDC Series 60 & 103 & 107.81 & 4.67 \\
\hline Caterpillar & 81.84 & 98.83 & 20.7 \\
\hline Navistar & 59.46 & 59.96 & 0.84 \\
\hline Volvo & 77.20 & 92.73 & 20.11 \\
\hline
\end{tabular}

\subsubsection{Power based fast NOx models for different transient cycles}

Power based instantaneous $\mathrm{NO}_{\mathrm{x}}$ emission models were derived for different transient test cycles like the ETC-E, CSHVR-E, WVU-E and Highway-E based on the test results available. These models were then applied to predict the fast $\mathrm{NO}_{\mathrm{x}}$ values.

The fast $\mathrm{NO}_{\mathrm{x}}$ emission model for the Highway-E cycle is given by Equation 12 .

$$
\left(N O_{x}\right)=0.0005021 *(B H P)+0.018 \quad \text { Equation } 12
$$

This model was then used to predict the FTP cycle test results. It predicted with an error of $12.68 \%$. Similarly, the model was used to predict ETC-E, WVU 5 Peak-E and the CSHVR-E cycles. The difference in the predicted values and the \% error of each of the cycles is given in the following table

Table 18 Instantaneous NOx emissions prediction for transient engine cycles

\begin{tabular}{|l|l|l|l|}
\hline \multicolumn{1}{|c|}{ Test Type } & $\begin{array}{l}\text { Experimental Fast } \mathrm{NO}_{\mathrm{x}} \\
\text { Cycle Integrated }(\mathrm{g} / \mathrm{s})\end{array}$ & $\begin{array}{l}\text { Predicted Fast } \mathrm{NO}_{\mathrm{x}} \\
\text { Cycle Integrated }(\mathrm{g} / \mathrm{s})\end{array}$ & \% error \\
\hline ETC-E & 105.07 & 95.45 & 9.15 \\
\hline CSHVR-E & 57.04 & 58.84 & 3.15 \\
\hline WVU 5 Peak -E & 33.80 & 34.89 & 3.22 \\
\hline FTP & 86.58 & 97.56 & 12.68 \\
\hline
\end{tabular}




\section{Chapter 6 Backward Transformation Techniques for $\mathrm{NO}_{\mathrm{x}}$ Emissions Prediction}

Standardized engine testing and emissions measurement using a full flow dilution tunnel and an analyzer provides the dilute emissions of a species but not the true exhaust manifold (raw) instantaneous emissions. There exists a delay and diffusion in the measured dilute emissions. The diffusion in time is considered mostly due to the analyzer dynamics, sampling system and the dilution in the tunnel. To improve the engine control systems, aftertreatment management devices, and for inventory models, it is desirable to measure the instantaneous emissions right at the engine outlet. Various studies have been done previously in which signal reconstruction techniques were used to determine the actual emissions during engine transients from the distorted output of a conventional exhaust gas analyzer. Beaumont et al. [25] used this technique by designing a finite horizon filter, which is a dual of generalized predictive control theory. Numerical models were also developed by Chan et al. [23]. The behavior of gas transportation through an emission analyzer was simulated by a series of alternatively arranged pipes and surge volumes such that the distortion of the emission signal could be physically explained and modeled. These models were then solved numerically to obtain the undistorted actual emission signals.

This study deals with the prediction of instantaneous raw emissions from diffused, dilute emissions measurements using algebraic methods.

\subsection{Backward transformations}

Backward transformation techniques are based on finding a correlation between conventionally measured (dilute) emissions and the true manifold (raw) instantaneous emissions. There are several ways in which backward transformations can be applied for 
instantaneous emissions prediction. One of them is the algebraic method, which is based on repeated iterations of the input signal to predict the output.

\subsubsection{Simple Transform or Algebraic Method}

The possibility of finding a matrix or algebraic approach to calculating instantaneous emissions at the engine from analyzer data that are diffused in time by sampling and measurement is the basis for this simple transform or algebraic method. Rather than use the realistic gamma function proposed by Ganesan et al. [13] first a very simple forward transform that caused signal smoothing simply to test approaches from a theoretical standpoint is considered. Consider the forward transform

$$
B_{i}=0.25 * A_{i-1}+0.5 * A_{i}+0.25 * A_{i+1}
$$

Equation 13

Where $A_{i}$ represents an input signal (as a string of values in time) and $B_{i}$ is a smoothed or "forward transformed" signal. It is emphasized that this simple transform in no way attempts to mimic real time diffusion implied by mixing in the tunnel and analyzer measurements. It is merely for illustration. Clearly it is easy to find $B_{i}$ given a string of values $\mathrm{A}_{\mathrm{i}}$, but the back-transform proves difficult.

$A_{i}=2 *\left\{B_{i}-0.25 * A_{i-1}-0.25 * A_{i+1}\right\}$

Equation 14

One may apply this equation repeatedly:

e.g.,

$$
A_{i-1}=2 *\left\{B_{i-1}-0.25 * A_{i-2}-0.25 * A_{i}\right\}
$$

\section{Equation 15}

Equation 15 may be substituted into Equation 14. Extending through several substitutions one finds that an 11-point formula is obtained which is given by 


$$
\begin{array}{rlr}
A_{i} \approx & 2 *\left\{2.3125 * B_{i}-1.6875 * B_{i-1}-1.6875 * B_{i+1}+0.9375 * B_{i-2}+0.9375 * B_{i+2}\right. & \text { Equation } 16 \\
& -0.40625 * B_{i+3}-0.40625 * B_{i-3}+0.28125 * B_{i-4}+0.28125 * B_{i+4} & \\
& \left.-0.03125 * B_{i-5}-0.03125 * B_{i+5}\right\} &
\end{array}
$$

\section{Equation 16}

From Equation 16 it is evident that the coefficient of $B_{i+5}$ is 74 times lower than the coefficient for $\mathrm{B}_{\mathrm{i}}$ i.e. as the number of substitutions increase the coefficients of higher $\mathrm{B}_{\mathrm{i}}$ 's continue to decrease. Hence the terms with trivial coefficients (terms higher than $\mathrm{B}_{\mathrm{i}+5}$ ) have been ignored to obtain Equation 16.

To test this backward transformation, fast $\mathrm{NO}_{\mathrm{x}}$ data, sampled raw, were smoothed using Equation 13. Equation 16 was then applied to these smoothed data to see if the original fast $\mathrm{NO}_{\mathrm{x}}$ signal could be reconstructed. Figure 72 shows the variation of the experimental fast $\mathrm{NO}_{\mathrm{x}}$, fast $\mathrm{NO}_{\mathrm{x}}$ data smoothed using Equation 13 and back-transform of smoothed fast $\mathrm{NO}_{\mathrm{x}}$ data using Equation 16 with time for an FTP cycle. It is evident that the back-transform gives a curve similar to the original fast $\mathrm{NO}_{\mathrm{x}}$ curve but not better than the smoothed fast $\mathrm{NO}_{\mathrm{x}}$ curve. In order to have a closer look at the data, a part of the FTP cycle is considered. Figure 73 shows 100 seconds of fast $\mathrm{NO}_{\mathrm{x}}$ data from the FTP, along with the smoothed data, and the back-transform of the smoothed fast $\mathrm{NO}_{\mathrm{x}}$ data. From Figure 73 it is evident that the back-transformed $\mathrm{NO}_{\mathrm{x}}$ (predicted fast $\mathrm{NO}_{\mathrm{x}}$ ) agrees reasonably with the raw fast $\mathrm{NO}_{\mathrm{x}}$ data and the smoothed raw fast $\mathrm{NO}_{\mathrm{x}}$ data for some points (e.g. sec 720) but at specific points (especially at peaks and valleys) it does not agree. For example, consider the emissions at second 795 (Figure 73): the back-transform of smoothed fast $\mathrm{NO}_{\mathrm{x}}$ gives about $0.28 \mathrm{~g} / \mathrm{s} \mathrm{NO}$ whereas the experimental raw fast $\mathrm{NO}_{\mathrm{x}}$ is about $0.35 \mathrm{~g} / \mathrm{s}$. This can be explained as the effect of the emissions from the previous second and the next second ( $\sec 794$ and sec 796) on the second of interest (sec 795) during the backward transformations. Also it is known that the algebraic backtransformation gives a worse fit to the original data than the smoothed data. Hence, the algebraic approach is not considered for further study. Alternatively, an approach based 
on neural networks can be considered as another method of backward transformation based $\mathrm{NO}_{\mathrm{x}}$ emissions prediction.

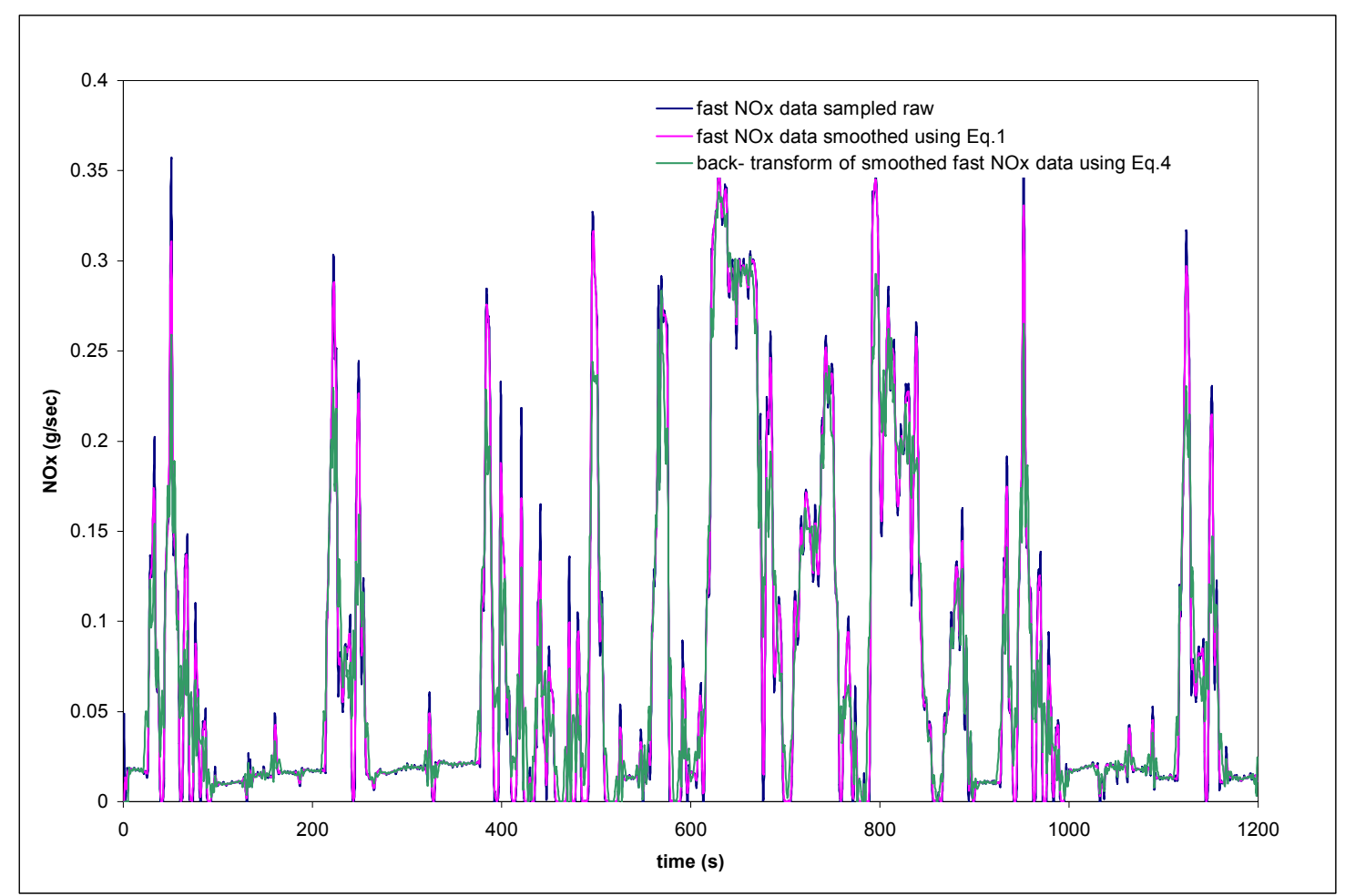

Figure 72 Fast $\mathrm{NO}_{\mathrm{x}}$ smoothed using Equation 13, back transformed fast $\mathrm{NO}_{\mathrm{x}}$ using Equation 16, slow $\mathrm{NO}_{\mathrm{x}}$ with time for the FTP cycle operated on the DDC Series 60 engine.

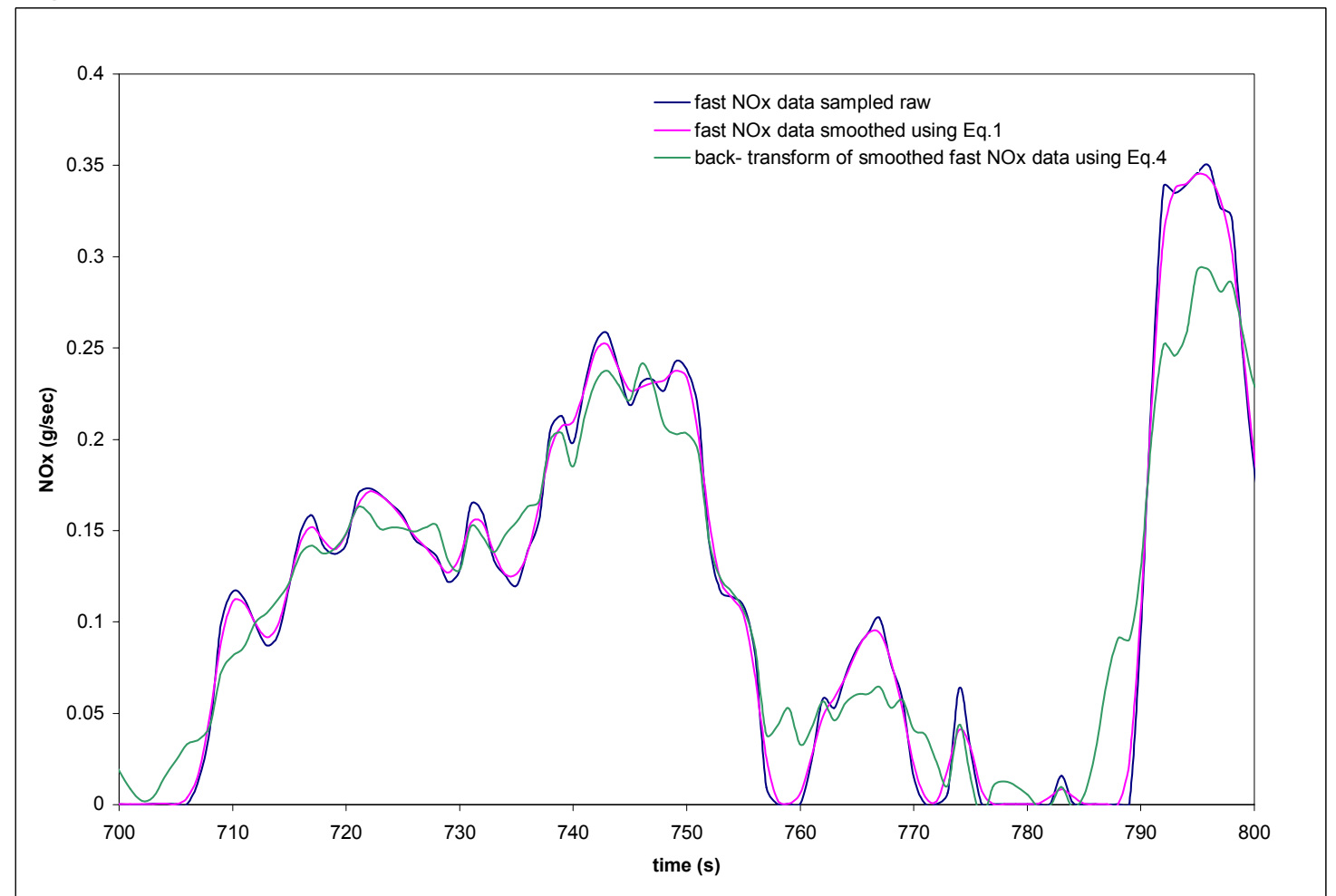

Figure 73 A part of the FTP cycle run on the DDC Series 60 considered for analysis. 


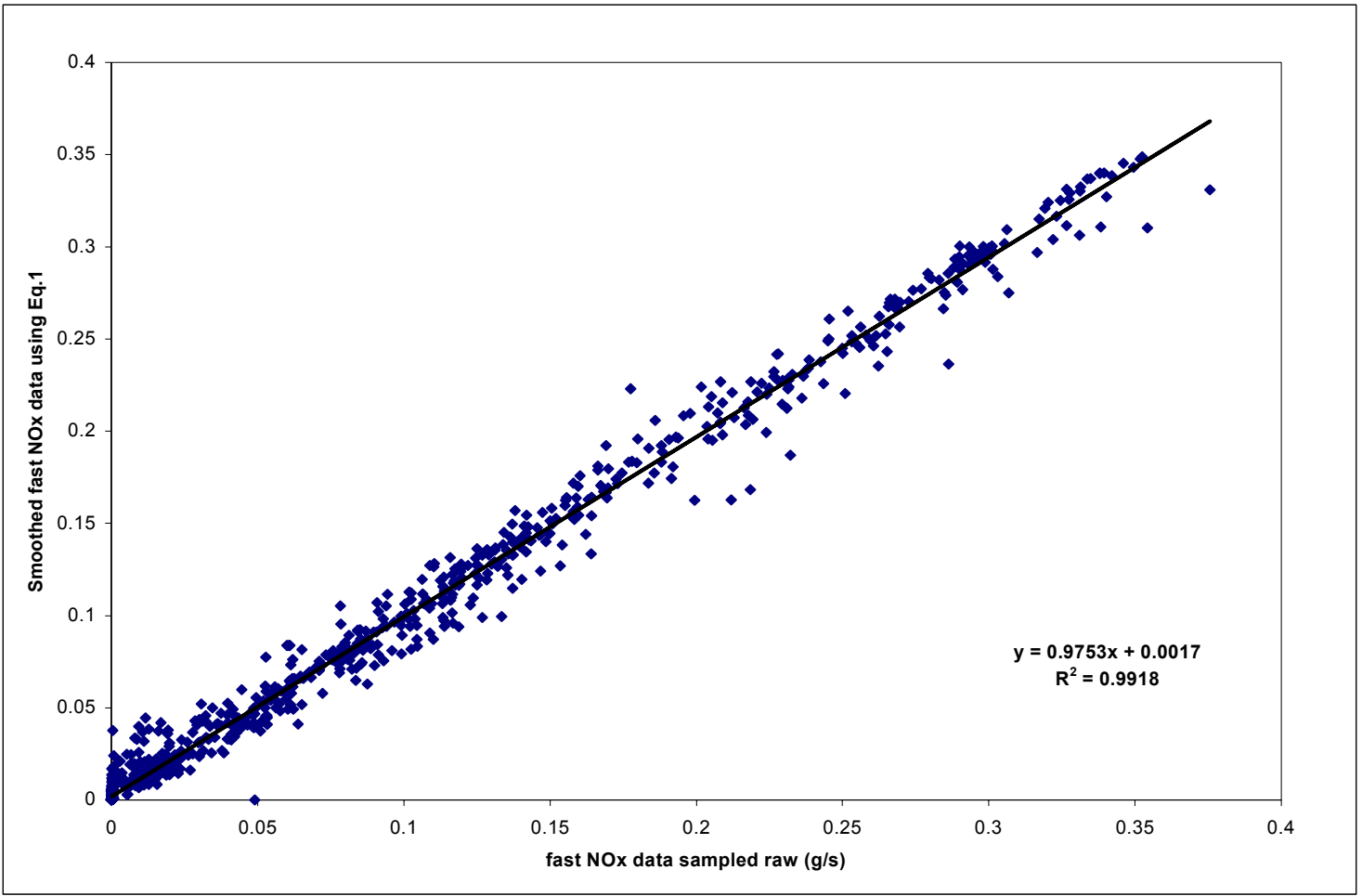

Figure 74 Fast $\mathrm{NO}_{\mathrm{x}}$ data sampled raw plotted against smoothed fast $\mathrm{NO}_{\mathrm{x}}$ data using Equation 13. 


\section{Chapter 7 Conclusions}

The main objectives of the thesis were measurement, comparison, analysis and prediction of $\mathrm{NO}_{\mathrm{x}}$ emissions using two different $\mathrm{NO}_{\mathrm{x}}$ analyzers. $\mathrm{NO}_{\mathrm{x}}$ emissions were measured with both the analyzers and the experimental results were compared. The comparison was based on engine type and test type. It is concluded that the cycle average and integrated values measured using both the analyzers differed by about $15-20 \%$. A part of this difference (about 5-8\%) was due to the $\mathrm{NO}_{2}$ content measured in the slow $\mathrm{NO}_{\mathrm{x}}$ data since the fast $\mathrm{NO}_{\mathrm{x}}$ measured only the $\mathrm{NO}$ content in the exhaust. Initially, for the tests performed on DDC Series, Model Year 2000 engine, the intake airflow rate was used for calculating the raw fast $\mathrm{NO}_{\mathrm{x}}$ emissions. Later, for the tests performed on other engines, the exhaust flowrate was recorded and $\mathrm{NO}_{\mathrm{x}}$ calculations were based on both intake and exhaust flowrates. It is concluded that the $\mathrm{NO}_{\mathrm{x}}$ emissions were increased by about $10 \%$ with calculations based on exhaust flowrate when compared to those based on intake airflow rate. The calculations based on intake airflow rate did not account for the fuel flow rate. This was another reason for the difference in slow and fast $\mathrm{NO}_{\mathrm{x}}$ data.

It is also concluded that there occurred a large analyzer drift in the measured fast $\mathrm{NO}_{\mathrm{x}}$. Tests conducted in the same conditions of temperature, pressure and humidity gave different results even though the analyzer was calibrated prior to each test. This is an important issue to be considered in future.

From the trapezoidal tests it is concluded that the slow $\mathrm{NO}_{\mathrm{x}}$ was unable to respond well for engine oscillations with less than 10 seconds time period and was almost completely unable to respond for oscillation with time period less than 4 seconds. From this, it could be concluded that the slow $\mathrm{NO}_{\mathrm{x}}$ analyzer is not a very good tool for studying the transient nature of test cycles even though its measurement accuracy was quite good. 
On the other hand, the fast $\mathrm{NO}_{\mathrm{x}}$ analyzer could respond very well to the transient nature of the trapezoidal cycles. This lead to the conclusion that fast $\mathrm{NO}_{\mathrm{x}}$ analyzer could be a very good tool to analyze the transient cycles. Its only limitation is its measurement inaccuracy, which is about $30 \%$.

The fast $\mathrm{NO}_{\mathrm{x}}$ results obtained during this study were tabulated in the form of inventory tables. These tables contained average instantaneous $\mathrm{NO}_{\mathrm{x}}$ emissions for certain speed and torque ranges for each of the six heavy-duty diesel engines tested. These could be used as look up table for quick references. These could be developed in future for large-scale instantaneous emissions inventory models like the EPA's MOVES model [33].

A universal power based instantaneous $\mathrm{NO}_{\mathrm{x}}$ emission prediction model was developed which could predict the values of FTP cycle for any typical heavy-duty diesel engine within an error of $20 \%$. Power based $\mathrm{NO}_{\mathrm{x}}$ models were also developed for other transient test cycles, which could predict the $\mathrm{NO}_{\mathrm{x}}$ emissions within an error of $13 \% \mathrm{~A}$ part of this difference could be attributed to the change in engine behavior and the test transients.

An attempt was made theoretically to predict the instantaneous $\mathrm{NO}_{\mathrm{x}}$ emissions from the dilute $\mathrm{NO}_{\mathrm{x}}$ emissions. For this the algebraic backward transformation techniques were used. These could not predict the emissions well because of the effect of interference of dispersions. Alternatively, the neural network based emissions prediction models are being developed.

Instead of power-based models, torque and speed based models can also be developed in future to have better emissions prediction than the models presently in use. 


\section{References}

1. Environmental Protection Agency, Office of Transportation and Air Quality Regulatory Announcement, "Proposed Heavy-Duty Engine and Vehicle Standards and Highway Diesel Fuel Sulfur Control Requirements," EPA420-F-00-022, May 2000.

2. "Gas Phase Measurement," Dieselnet Technology Guide, www.dieselnet.com.

3. "Measurement of Emissions," Dieselnet Technology Guide, www.dieselnet.com.

4. Baronick, J. D., Gruber, D., Fabinski, W., Lach, G., Schimpl, H., "Evaluation of an UV analyzer for $\mathrm{NO}_{\mathrm{x}}$ Vehicle Emission Measurement," SAE Technical Paper 200101-0213.

5. "Measurement of Carbon Dioxide, Carbon Monoxide, and Oxides of Nitrogen in Diesel Exhaust," SAE Standard, June 1995.

6. Nakumura, H., Kihara, N., Adachi, M., Ishida, K., "Development of a Wet-Based NDIR and its Application to On-Board Emission Measurement System," SAE Technical Paper 2002-01-0612.

7. Messer, J. T, "Measurement Delays and Modal Analysis for two Heavy Duty Transportable Emissions Testing Laboratories and a Stationary Engine Emission Testing Laboratory," West Virginia University Thesis, Morgantown, West Virginia, 1995.

8. Messer, J. T., Clark, N. N., Lyons, D. W., "Measurement Delays and Modal Analysis for a Heavy Duty Transportable Emissions Testing Laboratory," SAE Technical Paper 950218.

9. Ramamurthy, R., Clark, N. N., Atkinson, C. M., Lyons, D. W., "Models for Predicting Transient Heavy Duty Vehicle Emissions," SAE Technical Paper 982652, 1998.

10. Levenspiel, O., "Chemical Reaction Engineering," $2^{\text {nd }}$ ed., J. Wiley and Sons, New York, 1972, pp. 253-308.

11. Ramamurthy, R., "Heavy Duty Emissions Inventory and Prediction," West Virginia University Thesis, Morgantown, West Virginia, 1999.

12. Clark, N. N., Jarrett, R. P., Atkinson, C. M., "Field Measurements of Particulate Matter Emissions and Exhaust Opacity from Heavy-Duty Vehicles," Proceedings of the Air and Waste Management Association, PM 2.5, A Fine Particulate Standard Conference, Long Beach, CA, January 28-30, 1998.

13. Clark, N. N., Ganesan, B., "Relationship between Instantaneous and Measured Emissions in Heavy-Duty Applications," SAE Technical Paper 2001-01-3536.

14. Code of Federal Regulations, 40, Part 86, Subpart N, "Protection of Environment," U.S. Government Printing Office, 1998.

15. Bane, B. R., "A Comparison of Steady State and Transient Emissions from HeavyDuty Diesel Engine," West Virginia University Thesis, Morgantown, West Virginia, 2002.

16. Cirillo, E. D., "Development of a Micro-Dilution Tunnel System for In-Use, OnBoard Heavy Duty Vehicle Particulate Matter Emissions Measurement," West Virginia University Thesis, Morgantown, West Virginia, 2001.

17. Cambustion Limited, $\mathrm{fNO}_{\mathrm{x}} 400$, Users Manual.

18. Emission Test Cycles, www.dieselnet.com, Ecopoint Inc., September 2001.

19. Clark, N. N., Daley, J. J., Nine, R., Atkinson, C. M., "Applications of the New CitySuburban Heavy Vehicle Route (CSHVR) to Truck Emissions Characterizations," SAE Technical Paper 1999-01-1467, 1999. 
20. Clark, N. N., Nine, R., Norton, P., "Effect on emissions of Multiple Driving Test Schedules Performed on Two Heavy-Duty Vehicles," SAE Technical Paper 2000-012818, 2000.

21. Collier, T. R., Gregory, D., Rushton, M., Hands, T., "Investigation into the Performance of an Ultra-fast Response $\mathrm{NO}$ Analyzer Equipped with a $\mathrm{NO}_{2}$ to $\mathrm{NO}$ Converter for Gasoline and Diesel Exhaust $\mathrm{NO}_{\mathrm{x}}$ Measurements," SAE Technical Paper 2000-01-2954, 2000.

22. Corrigon, E. R., "Evaluating Heavy-Duty Diesel Engine Aftertreatment Devices with a Split Exhaust Configuration," West Virginia University Thesis, Morgantown, West Virginia, 2001.

23. Hwa, C. S., Chen, X. S., "Characterization and Signal Interference of a NDIR Automotive Emission Analyzer Used for Dynamic Measurement," SAE Technical Paper 950223, 1995.

24. Callahan, T. J., Ryan, T. W., Martin, S. F., Waytulonis, R. W., "Comparison of Predicted and Measured Diesel Exhaust Emission Levels During Transient Operation," SAE Technical Paper 872140, 1987.

25. Beaumont, A. J., Noble, A. D., Pilley, A. D., "Signal Reconstruction Techniques for Improved Measurement of Transient Emissions," SAE Technical Paper 900233, 1990.

26. Khair, M., Lemaire, J., Fischer, S., "Integration of Exhaust Gas Recirculation, Selective Catalytic Reduction, Diesel Particulate Filters, and Fuel-Borne Catalyst for $\mathrm{NO}_{\mathrm{x}} / \mathrm{PM}$ Reduction," SAE Technical Paper 2000-01-1933, 2000.

27. Shade, B. C., "A Performance Evaluation of the MEMS - An On-Road Emissions Measurement System Study," West Virginia University Thesis, Morgantown, West Virginia, 2000.

28. Tomthy, V. J., "Diesel Emission Control - Last 12 Months in Review," SAE Technical Paper 2000-01-2817, 2000.

29. Plint, M., Martyr, A., "Engine Testing - Theory and Practice," $2^{\text {nd }}$ ed., SAE International Publication.

30. Meyer, E. T., "Evaluation of Exhaust Flowrate Measurement Techniques for a Mobile Emissions Monitoring System," West Virginia University Thesis, Morgantown, West Virginia, 2001.

31. Fuller, A. D., "A Flow Rate Measurement System for a Mobile Emissions Measurement System," West Virginia University Thesis, Morgantown, West Virginia, 2001.

32. McClure, B. T., "Characterization of the Transient Response of a Diesel Exhaust-Gas Measurement System," SAE Technical Paper 881320, 1988.

33. "Environmental Protection Agency - Multi-scale Motor Vehicles and Equipment Emission System (MOVES)", Weblink: www.epa.gov/otaq/models.htm.

34. Heywood, J. B., "Internal Combustion Engines", McGraw Hill International Edition.

35. Weblink: www.msha.gov/nioshmnmfilterselectionguide/mnm_dpf_explanations. 


\section{Appendix}

Apart from the FTP cycles, various other transient test cycles were executed on different heavy-duty diesel engines. The test results obtained from the DDC Series 60 , 2000 Model Year are discussed below.

\section{European Transient Cycle (ETC-E)}

The next test after FTP cycle conducted on the DDC Series 60 engine (2000 model) is the European Transient Cycle (ETC). Speed time trace of ETC has been discussed in Chapter 3. The ETC cycle is less transient than the FTP cycle. Work done during the ETC cycle is $44.62 \mathrm{bhp}-\mathrm{hr}$ and the brake specific fuel consumed is 0.42 lb./bhp-hr. Cycle average emissions measured by the slow $\mathrm{NO}_{\mathrm{x}}$ analyzer are $0.058 \mathrm{~g} / \mathrm{s}$ and those from the fast $\mathrm{NO}$ analyzer are $0.055 \mathrm{~g} / \mathrm{s}$. Brake specific $\mathrm{NO}_{\mathrm{x}}$ emissions obtained from continuous sampling are $2.235 \mathrm{~g} / \mathrm{bhp}-\mathrm{hr}$. $\mathrm{NO}_{\mathrm{x}}$ emissions obtained from the ETC cycle on the DDC Series 60 engine are plotted against time in Figure 75 (without time shift) and Figure 76 (with time shift). $\mathrm{NO}_{\mathrm{x}}$ emissions and power variation with time are shown in Figure 77. From the figure it is evident that $\mathrm{NO}_{\mathrm{x}}$ emissions behave in harmony with power. Variation of fast $\mathrm{NO}$ and slow $\mathrm{NO}_{\mathrm{x}}$ with power are given in Figures 78 and 79 respectively. From the figures it is evident that $\mathrm{fNO}_{\mathrm{x}}$ values reach upto $0.35 \mathrm{~g} / \mathrm{s}$ whereas slow $\mathrm{NO}_{\mathrm{x}}$ values reach upto $0.30 \mathrm{~g} / \mathrm{s}$ i.e., raw emissions have higher $\mathrm{NO}_{\mathrm{x}}$ values

when compared to the dilute emissions. In this cycle, the $\mathrm{R}^{2}$ value of $\mathrm{fNO}_{\mathrm{x}}$ and power is lower than the $\mathrm{R}^{2}$ value of slow $\mathrm{NO}_{\mathrm{x}}$ and power. This may be due to the data scatter of the raw fast $\mathrm{NO}_{\mathrm{x}}$ values. 


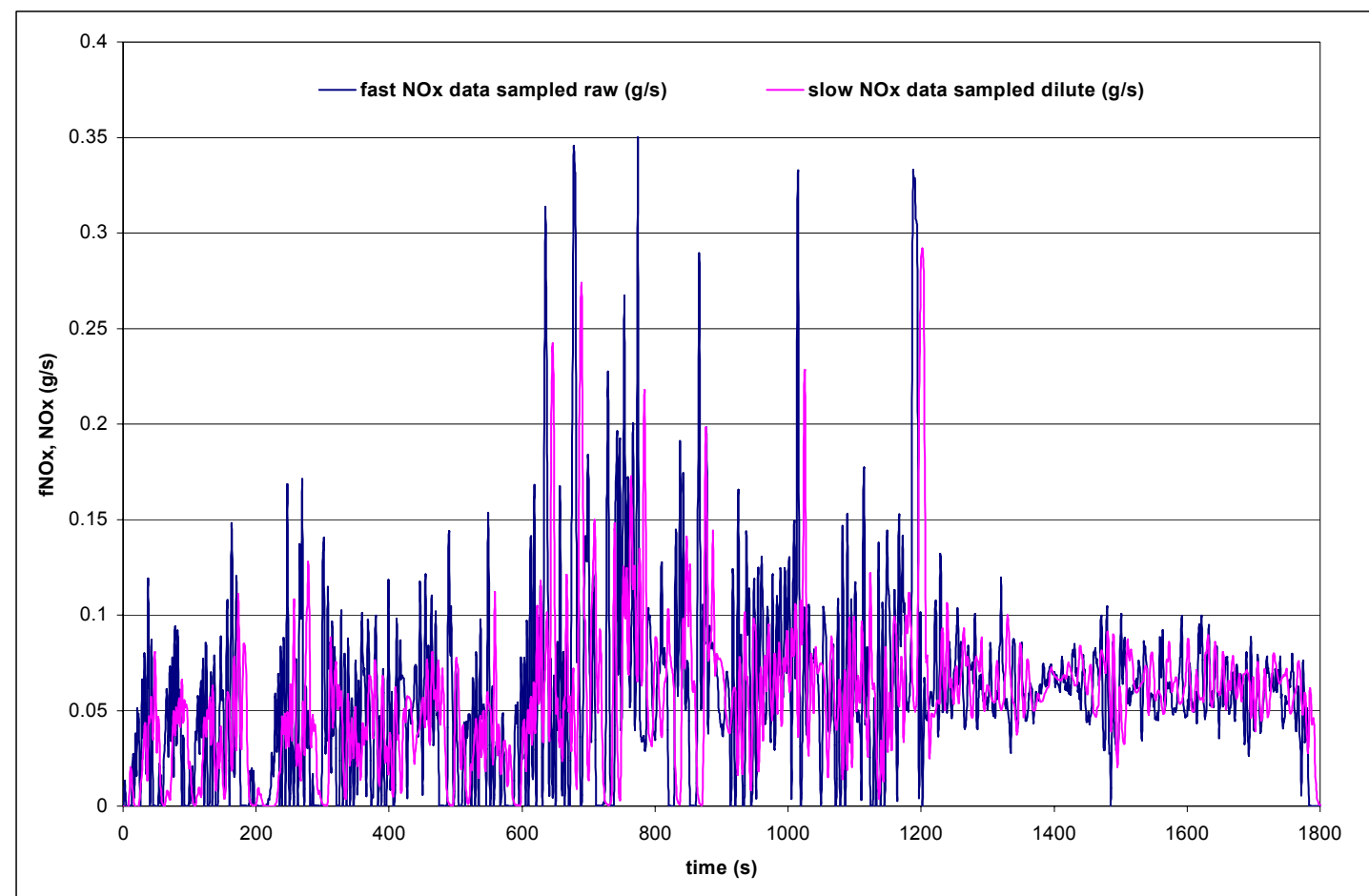

Figure 75 Variation of slow and fast $\mathrm{NO}_{\mathrm{x}}$ emissions with time for the ETC - E cycle run on the DDC Series 60 engine.

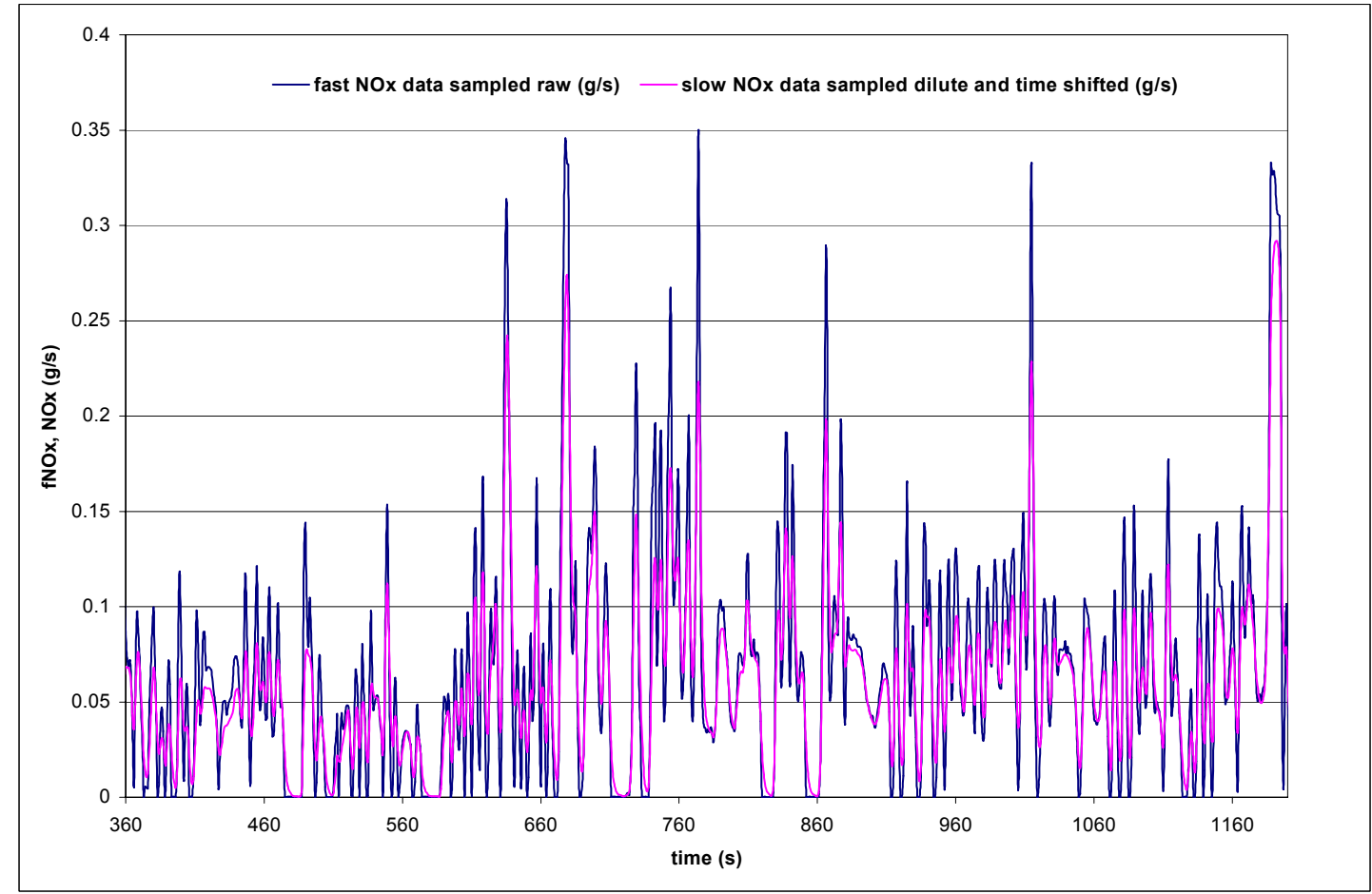

Figure 76 Variation of slow and fast $\mathrm{NO}_{\mathrm{x}}$ emissions with time for the ETC - E with slow $\mathrm{NO}_{\mathrm{x}}$ accounted for time delay. 


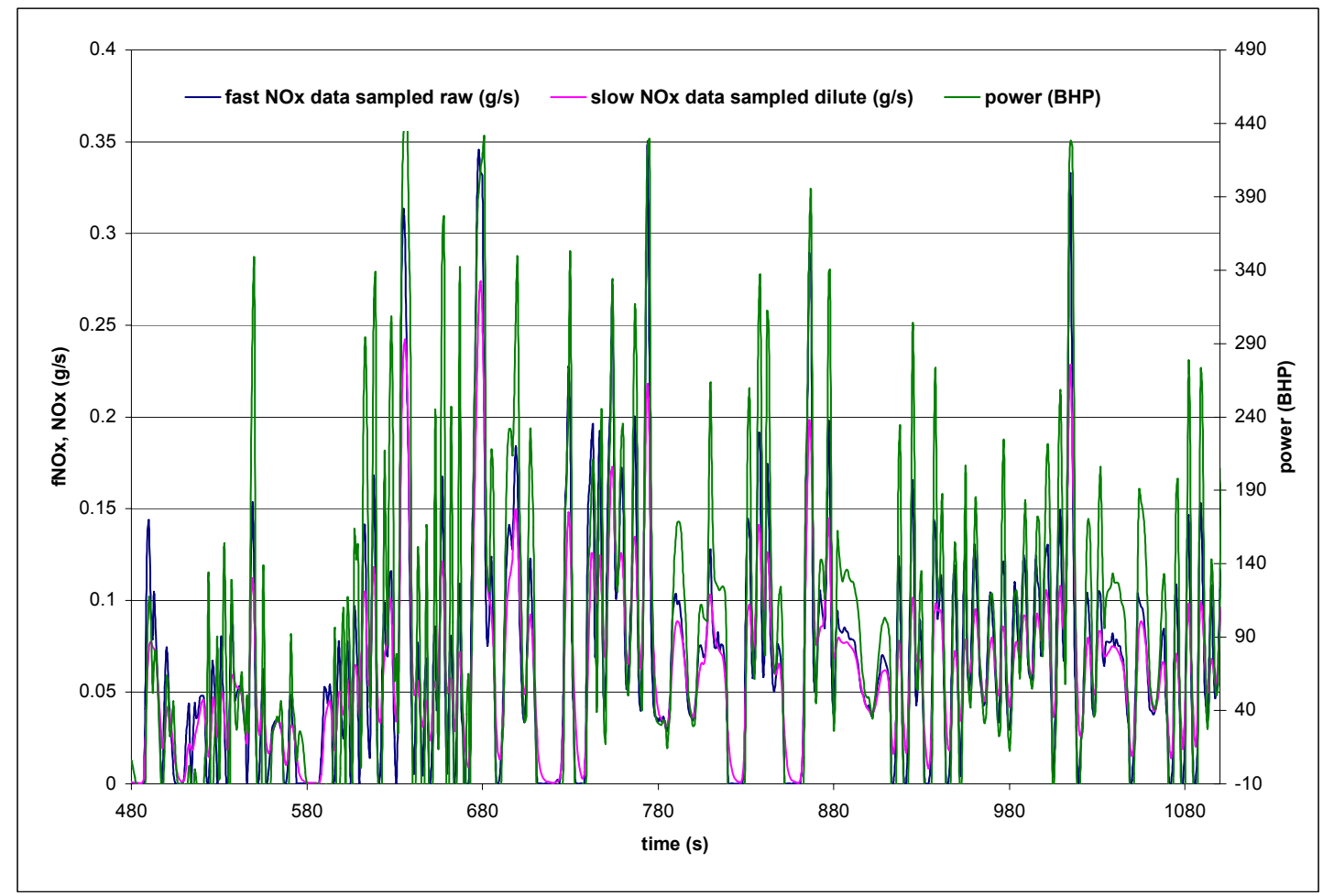

Figure 77 Variation of power and $\mathrm{NO}_{\mathrm{x}}$ emissions with time for the ETC - E cycle.

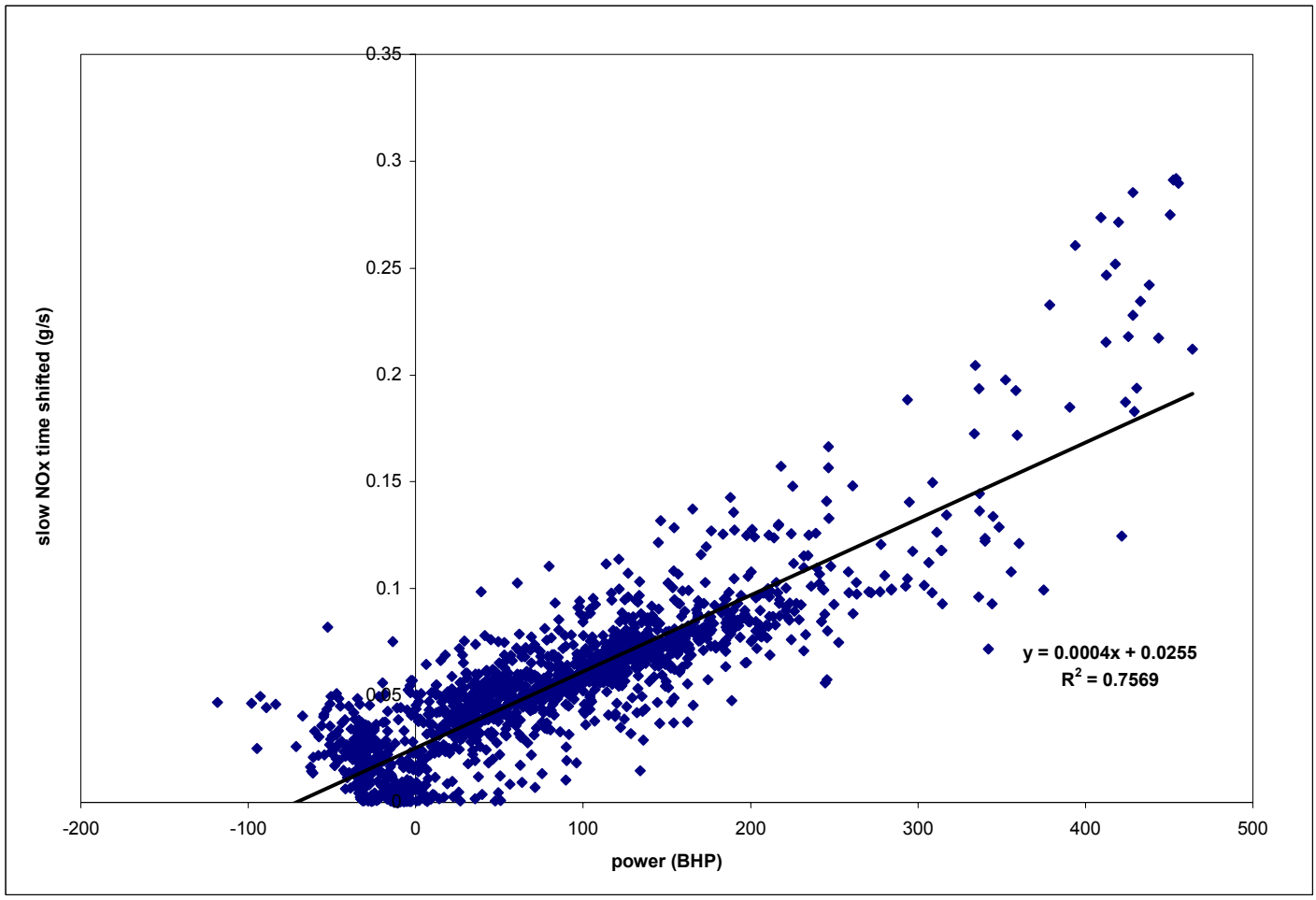

Figure 78 Relation between slow $\mathrm{NO}_{\mathrm{x}}$ and power for the ETC - E cycle. 


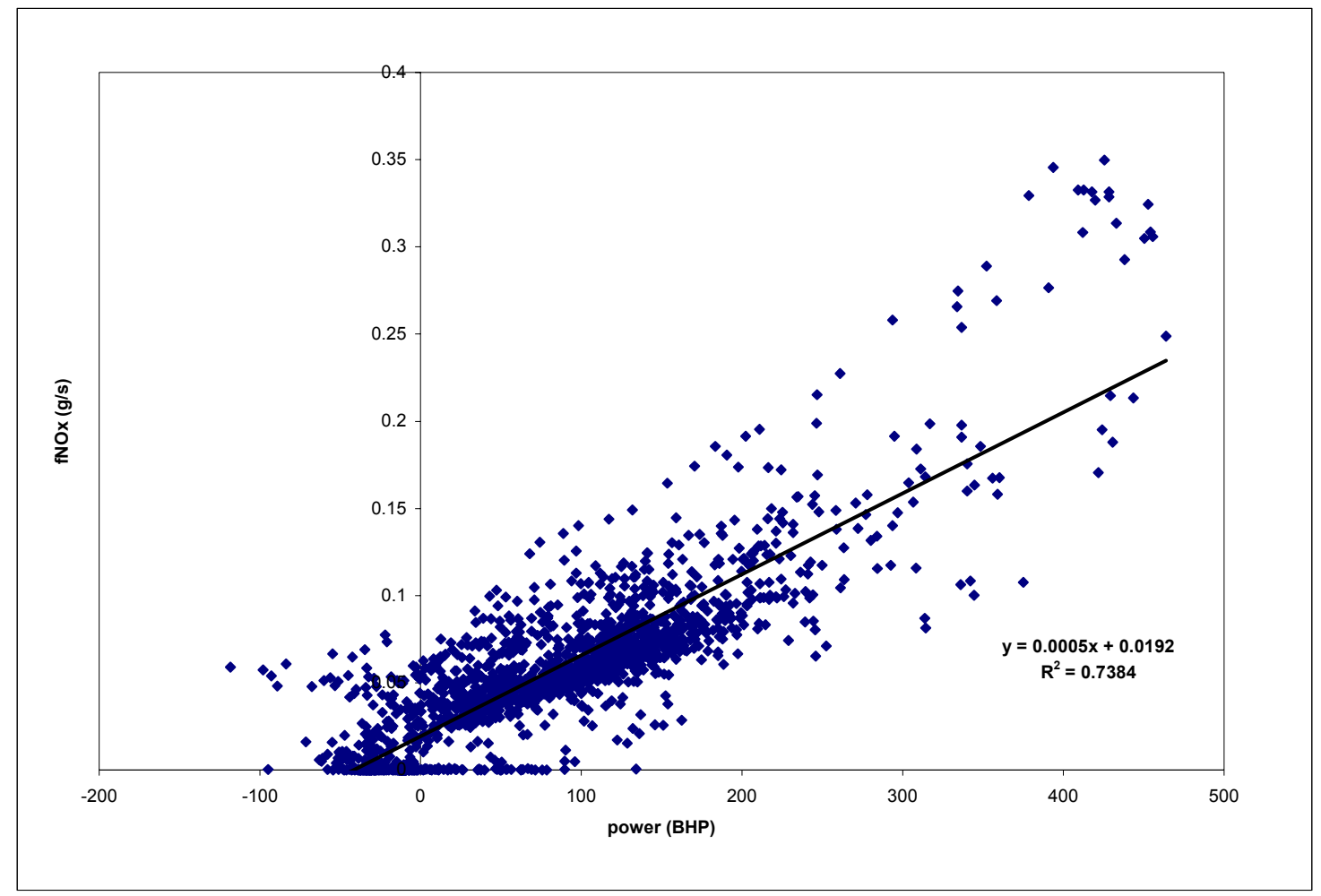

Figure 79 Relation between fast $\mathrm{NO}_{\mathrm{x}}$ and power for the ETC $-\mathrm{E}$ cycle run on the DDC Series 60 engine.

\section{CSHVR-E Cycle:}

A detailed description of the CSHVR-E and its origin is given in Chapter 3. The engine was warmed up before the cycle. Actual work done during the cycle was 21.77 bhp-hr and the brake specific fuel consumed was $0.46 \mathrm{lb} / \mathrm{bhp}-\mathrm{hr}$. $\mathrm{NO}_{\mathrm{x}}$ emissions were measured using both the analyzers. Cambustion fast $\mathrm{NO}$ analyzer sampled raw NO emissions and Rosemount slow $\mathrm{NO}_{\mathrm{x}}$ analyzer sampled dilute emissions. Variation of $\mathrm{NO}_{\mathrm{x}}$ emissions with time is given in Figures 80 (without time shift) and 81 (with time shift). The cycle average emissions obtained from the slow $\mathrm{NO}_{\mathrm{x}}$ data were $0.035 \mathrm{~g} / \mathrm{s}$ and those from the fast $\mathrm{NO}$ data were $0.033 \mathrm{~g} / \mathrm{s}$. Continuous sampling gave $2.46 \mathrm{~g} / \mathrm{bhp}$-hr slow $\mathrm{NO}_{\mathrm{x}}$. Variation of emissions and power with time is shown in Figure 82. Power and $\mathrm{NO}_{\mathrm{x}}$ plots are shown in Figures 83 and 84. For the slow $\mathrm{NO}_{\mathrm{x}}$ and power, an $\mathrm{R}^{2}$ value of 0.6693 is obtained and the $\mathrm{R}^{2}$ value of fast $\mathrm{NO}_{\mathrm{x}}$ and power is 0.7239 . The increase in $\mathrm{R}^{2}$ value for the correlation between fast $\mathrm{NO}_{\mathrm{x}}$ and power could be due to the transient nature of the 
CSHVR-E cycle. Power based fast $\mathrm{NO}_{\mathrm{x}}$ emission model is obtained by a linear correlation between fast $\mathrm{NO}$ and power.

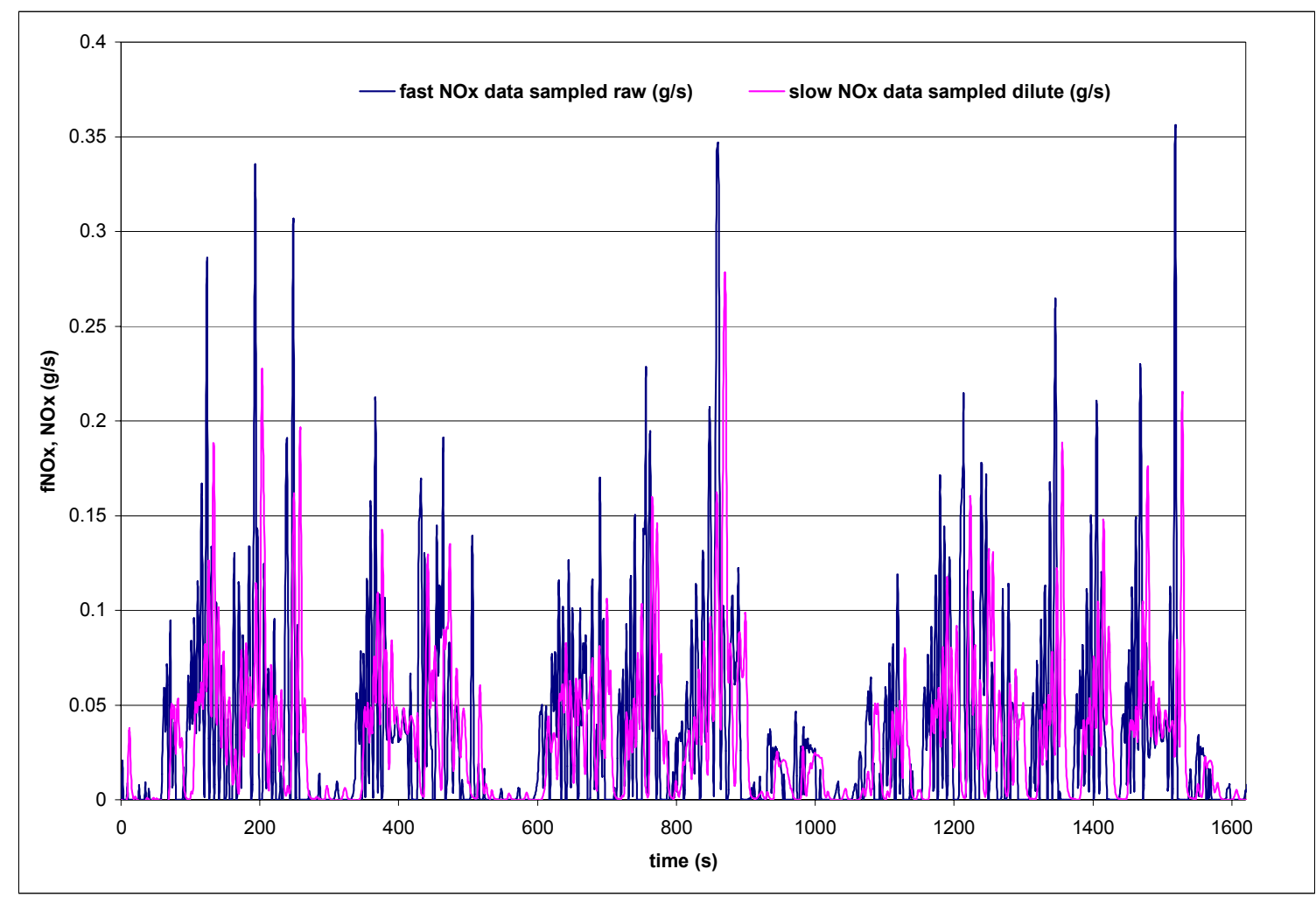

Figure 80 Variation of NOx emissions with time for the CSHVR - E cycle operated on the DDC Series 60 engine.

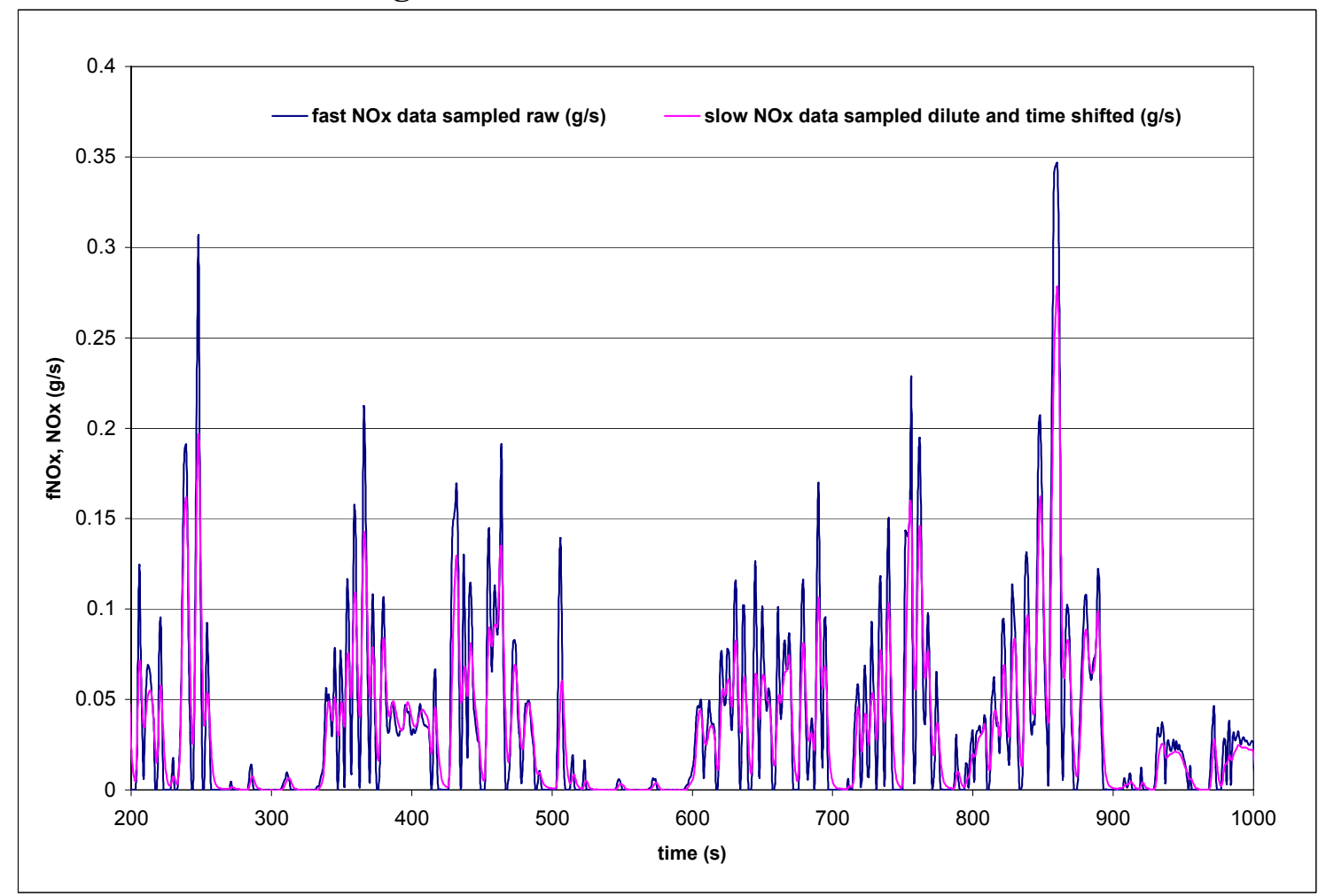

Figure 81 Variation of $\mathrm{NO}_{\mathrm{x}}$ emissions with time for the CSHVR - E cycle (slow $\mathrm{NO}_{\mathrm{x}}$ shifted for the time delay) run on the DDC Series 60 engine. 


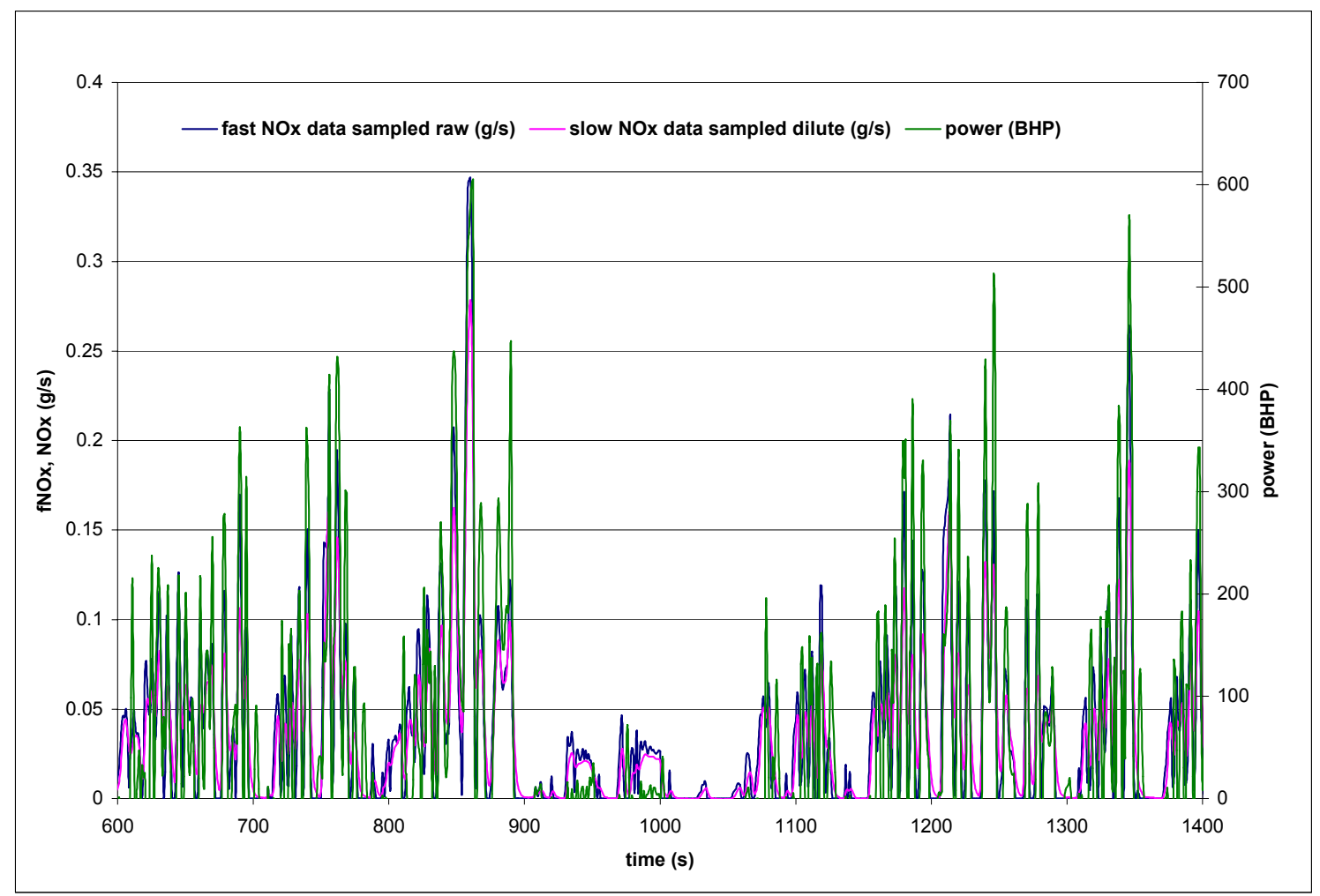

Figure 82 Variation of $\mathrm{NO}_{\mathrm{x}}$ emissions and power with time for the CSHVR - E cycle

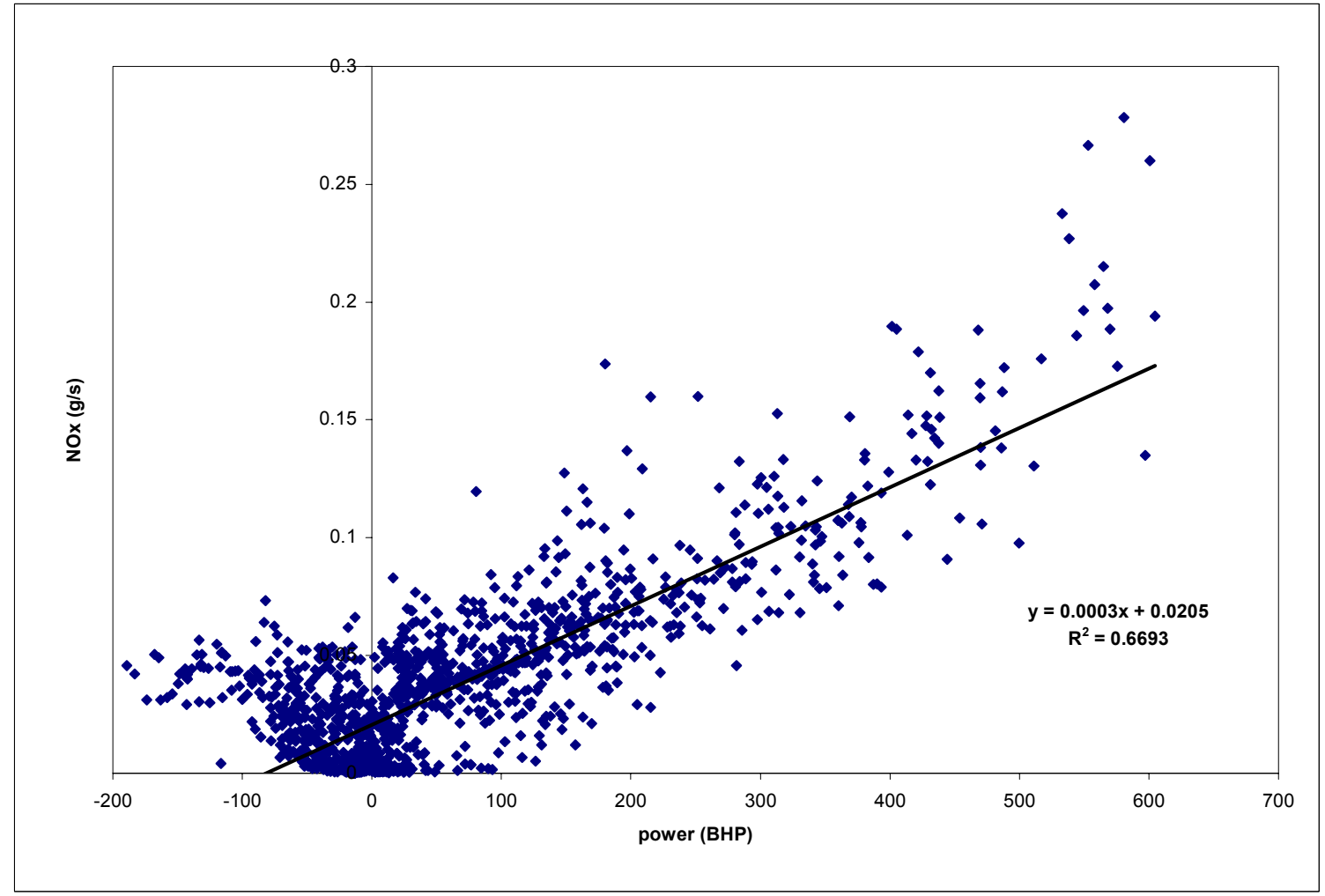

Figure 83 Relation between slow $\mathrm{NO}_{\mathrm{x}}$ and power for the CSHVR - E cycle. 


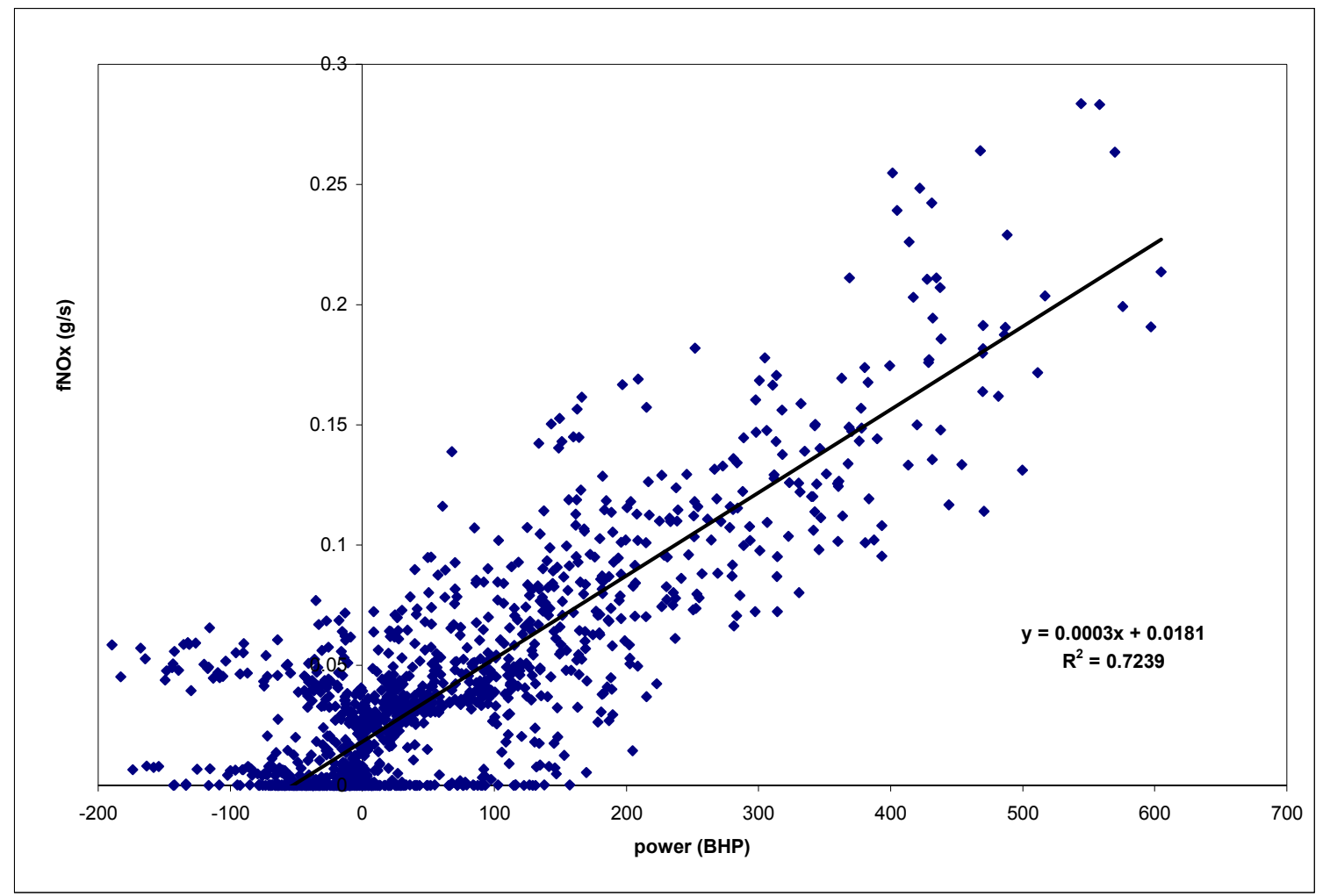

Figure 84 Relation between fast $\mathrm{NO}_{\mathrm{x}}$ and power for the CSHVR - E cycle run on the DDC Series 60 engine.

Highway-E Cycle:

Highway cycle is described in detail in Chapter 3. Actual work done during the cycle on a DDC Series 60 engine is $39.19 \mathrm{bhp}-\mathrm{hr}$ and the brake specific fuel consumed is $0.426 \mathrm{lb} . / \mathrm{bhp}-\mathrm{hr}$. Both the analyzers sampled $\mathrm{NO}_{\mathrm{x}}$ emissions and their average values for the cycle were $0.056 \mathrm{~g} / \mathrm{s}$ and $0.052 \mathrm{~g} / \mathrm{s}$. Brake specific $\mathrm{NO}_{\mathrm{x}}$ emissions obtained from continuous sampling are $2.51 \mathrm{~g} / \mathrm{bhp}-\mathrm{hr}$. Variation of $\mathrm{NO}_{\mathrm{x}}$ emissions with time are shown in Figure 85 for the two analyzers. The same graph is modified for time shift and is given in Figure 86. The relations of power, fast $\mathrm{NO}_{\mathrm{x}}$ and slow $\mathrm{NO}_{\mathrm{x}}$ with time are plotted in Figure 87. Variation of power and $\mathrm{NO}_{\mathrm{x}}$ emissions is given in Figures 88 and 89. In this case again the fast $\mathrm{NO}_{\mathrm{x}}$ correlation with power is not better than the slow $\mathrm{NO}_{\mathrm{x}}$. The reason could be less transient nature of the cycle and hence the data scatter for the fast $\mathrm{NO}_{\mathrm{x}} \cdot$ 


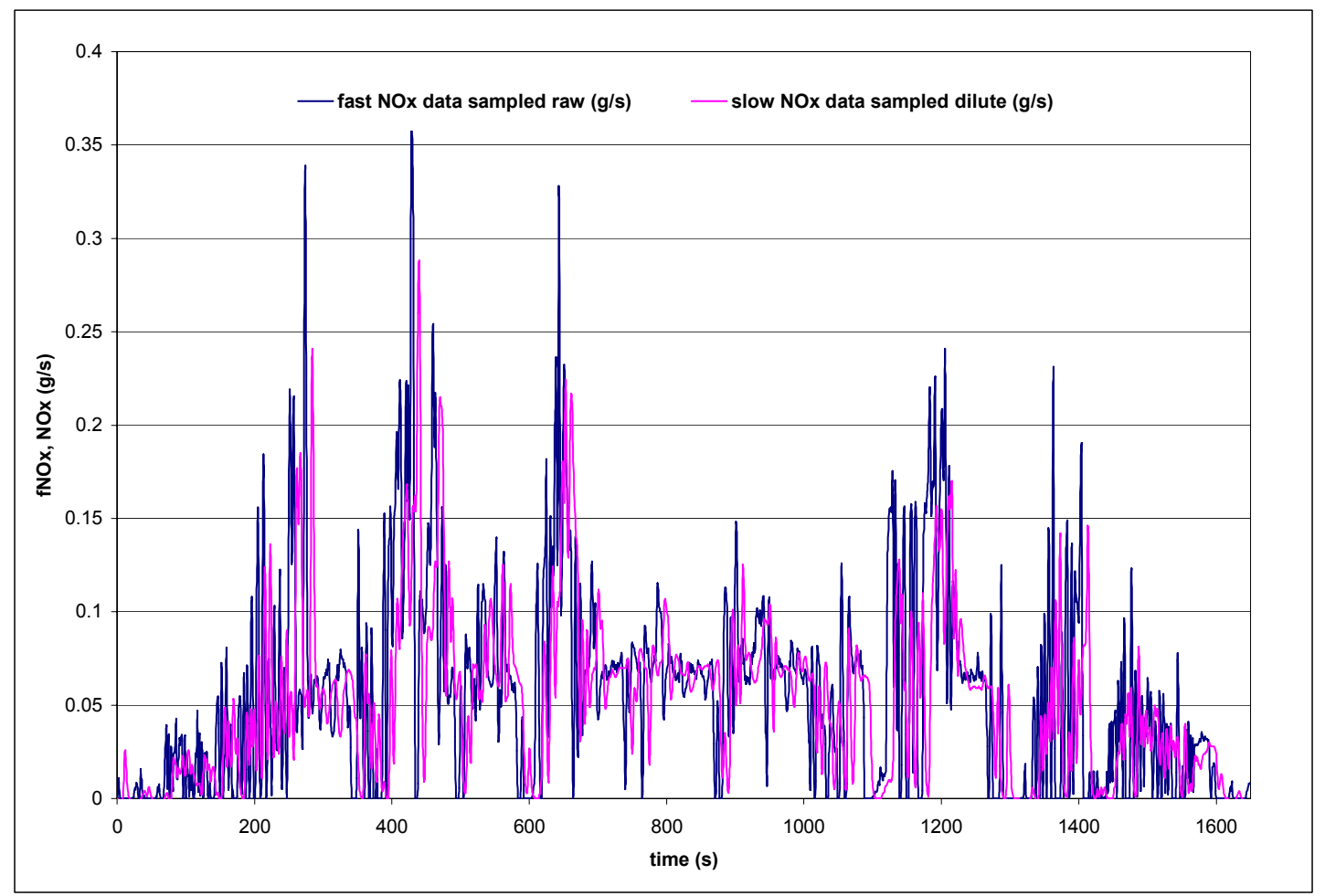

Figure 85 Variation of $\mathrm{NO}_{\mathrm{x}}$ emissions with power for the Highway - E cycle operated on the DDC Series 60 engine.

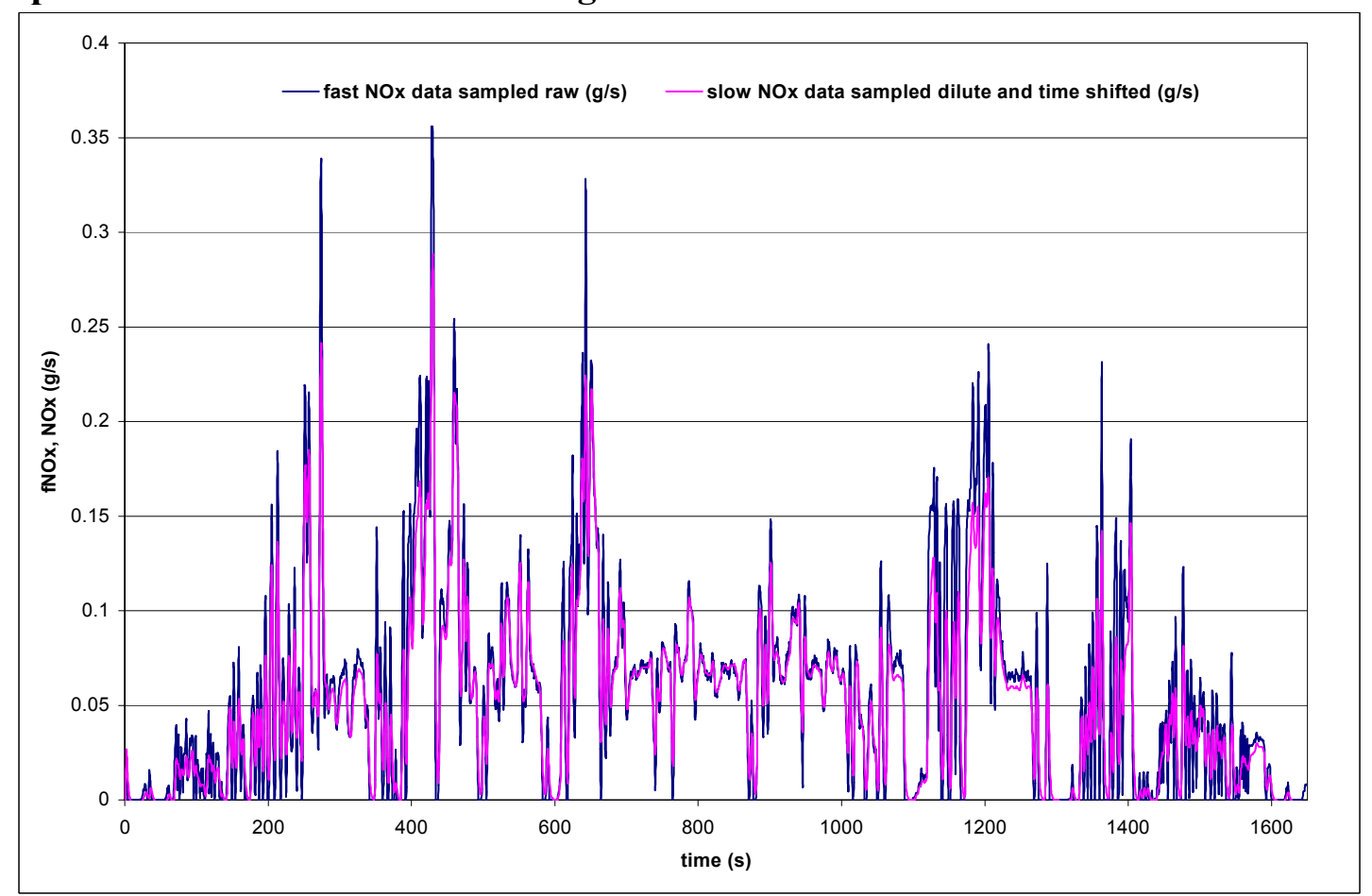

Figure 86 Variation of $\mathrm{NO}_{\mathrm{x}}$ emissions with time for the Highway - E cycle with slow $\mathrm{NO}_{\mathrm{x}}$ data shifted for the time delay. 


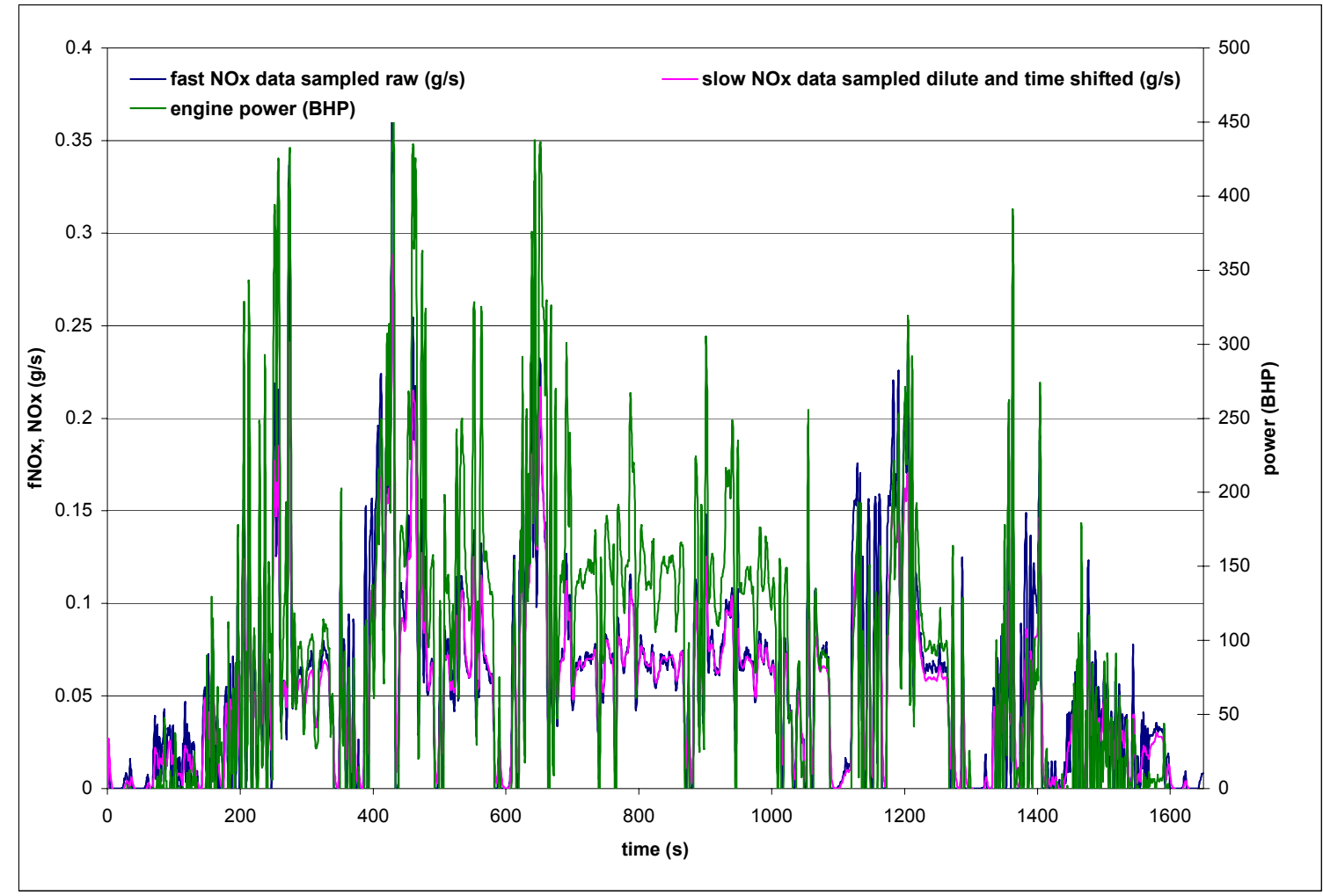

Figure 87 Power, slow $\mathrm{NO}_{\mathrm{x}}$ and fast $\mathrm{NO}_{\mathrm{x}}$ variation with time for the Highway $-\mathrm{E}$ cycle.

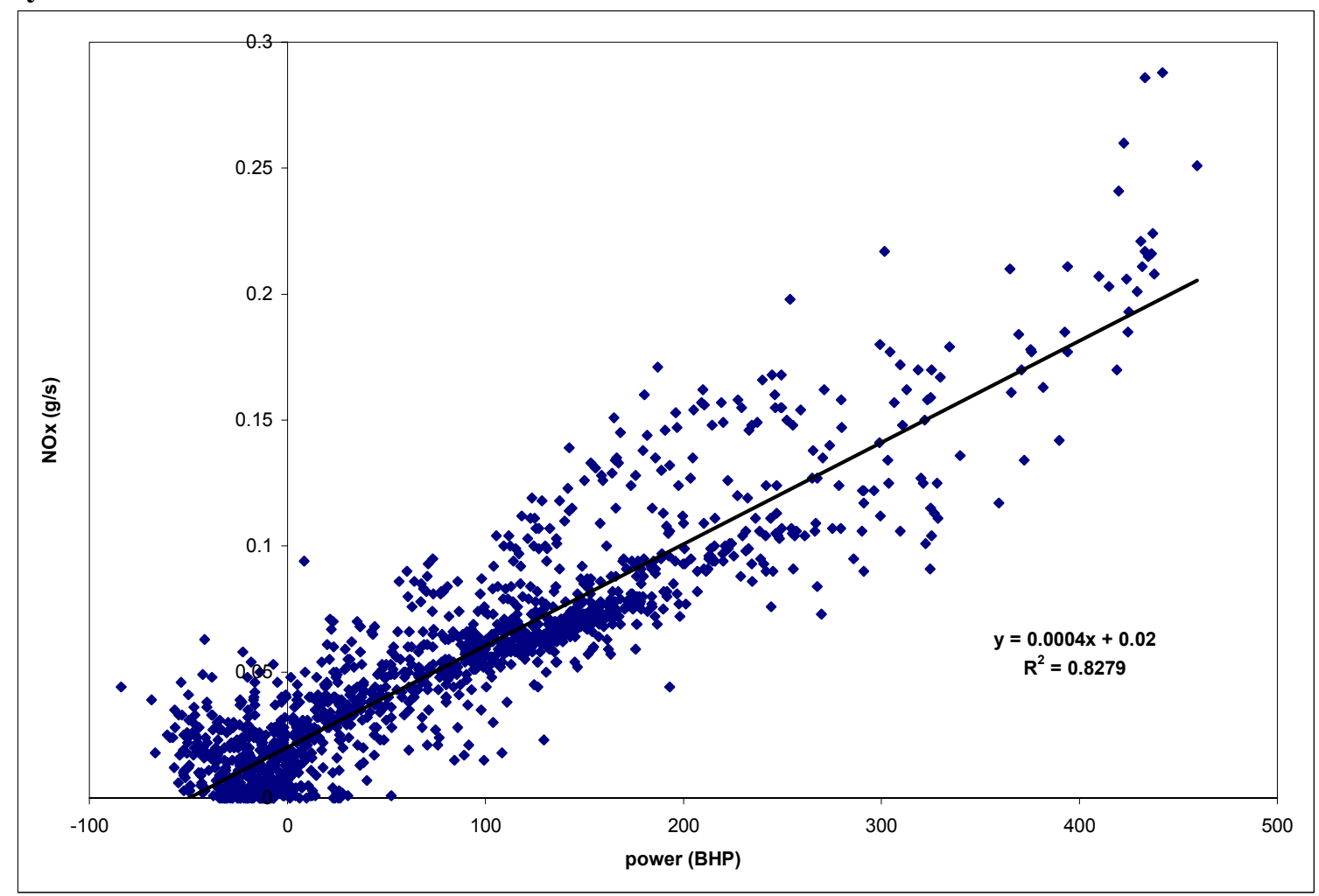

Figure 88 Relation between slow $\mathrm{NO}_{\mathrm{x}}$ and power for the Highway - E cycle. 


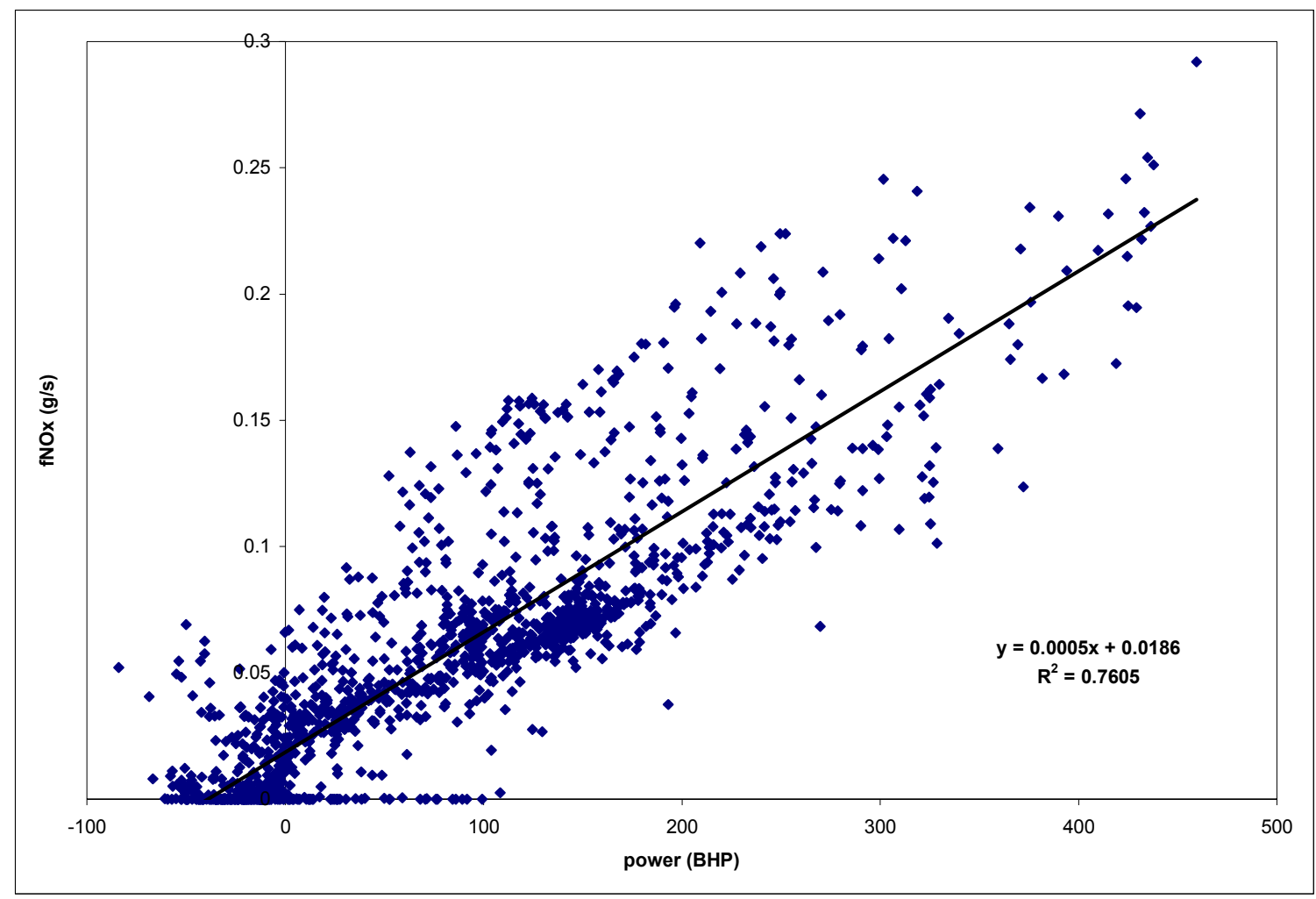

Figure 89 Relation between fast $\mathrm{NO}_{\mathrm{x}}$ and power for the Highway - E cycle run on the DDC Series 60 engine.

WVU 5 - Peak Cycle:

WVU 5 peak-E cycle is run on the DDC series 60 engine for measuring the $\mathrm{NO}_{\mathrm{x}}$ emissions. This cycle is described in detail in Chapter 3. This is a transient cycle with duration of 900 seconds. Actual work done during the cycle is $12.19 \mathrm{bhp}$-hr and the brake specific fuel consumed is $0.486 \mathrm{lb} / \mathrm{bhp}-\mathrm{hr} . \mathrm{NO}_{\mathrm{x}}$ data is measured using both the analyzers. Variation of $\mathrm{NO}_{\mathrm{x}}$ emissions with time is as shown in Figure 90. Time shifted $\mathrm{NO}_{\mathrm{x}}$ and time is given in Figure 91. Cycle average $\mathrm{NO}_{\mathrm{x}}$ emissions measured using the fast $\mathrm{NO}_{\mathrm{x}}$ analyzer are $0.037 \mathrm{~g} / \mathrm{s}$ and those measured using the slow $\mathrm{NO}_{\mathrm{x}}$ analyzer are $0.054 \mathrm{~g} / \mathrm{s}$. Brake specific $\mathrm{NO}_{\mathrm{x}}$ emissions obtained during continuous sampling are $4.0 \mathrm{~g} / \mathrm{bhp}-\mathrm{hr}$. Variation of $\mathrm{NO}_{\mathrm{x}}$ emissions and power with time is shown in Figure 92. $\mathrm{NO}_{\mathrm{x}}$ emissions with power are given in Figures 93 and 94 . In this case there is a slight increase in the $\mathrm{R}^{2}$ value of fast $\mathrm{NO}_{\mathrm{x}}$ and power when compared to slow $\mathrm{NO}_{\mathrm{x}}$ and power. 


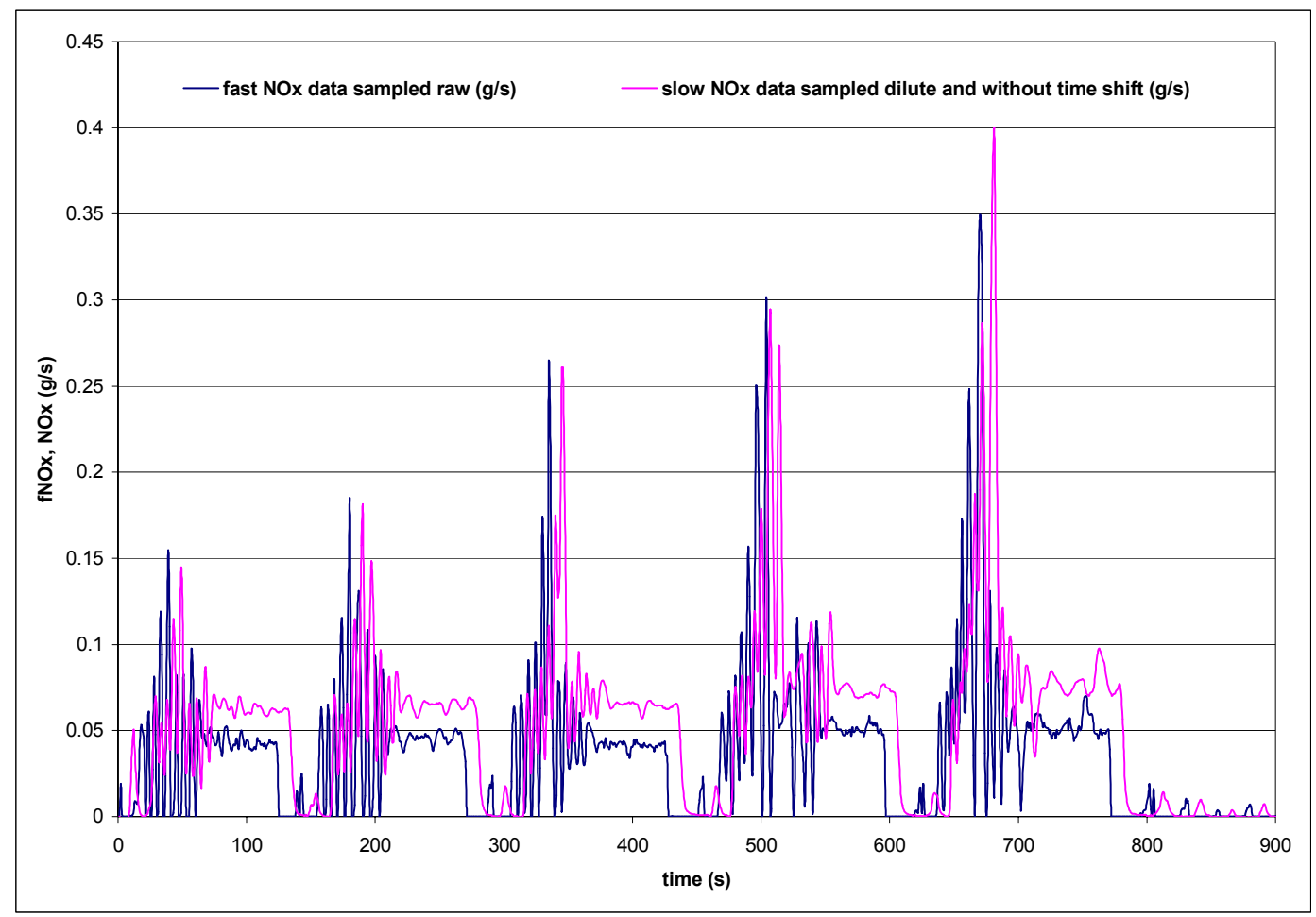

Figure 90 Variation of $\mathrm{NO}_{\mathrm{x}}$ emissions with time for the WVU 5 - Peak cycle operated on the DDC Series 60 engine.

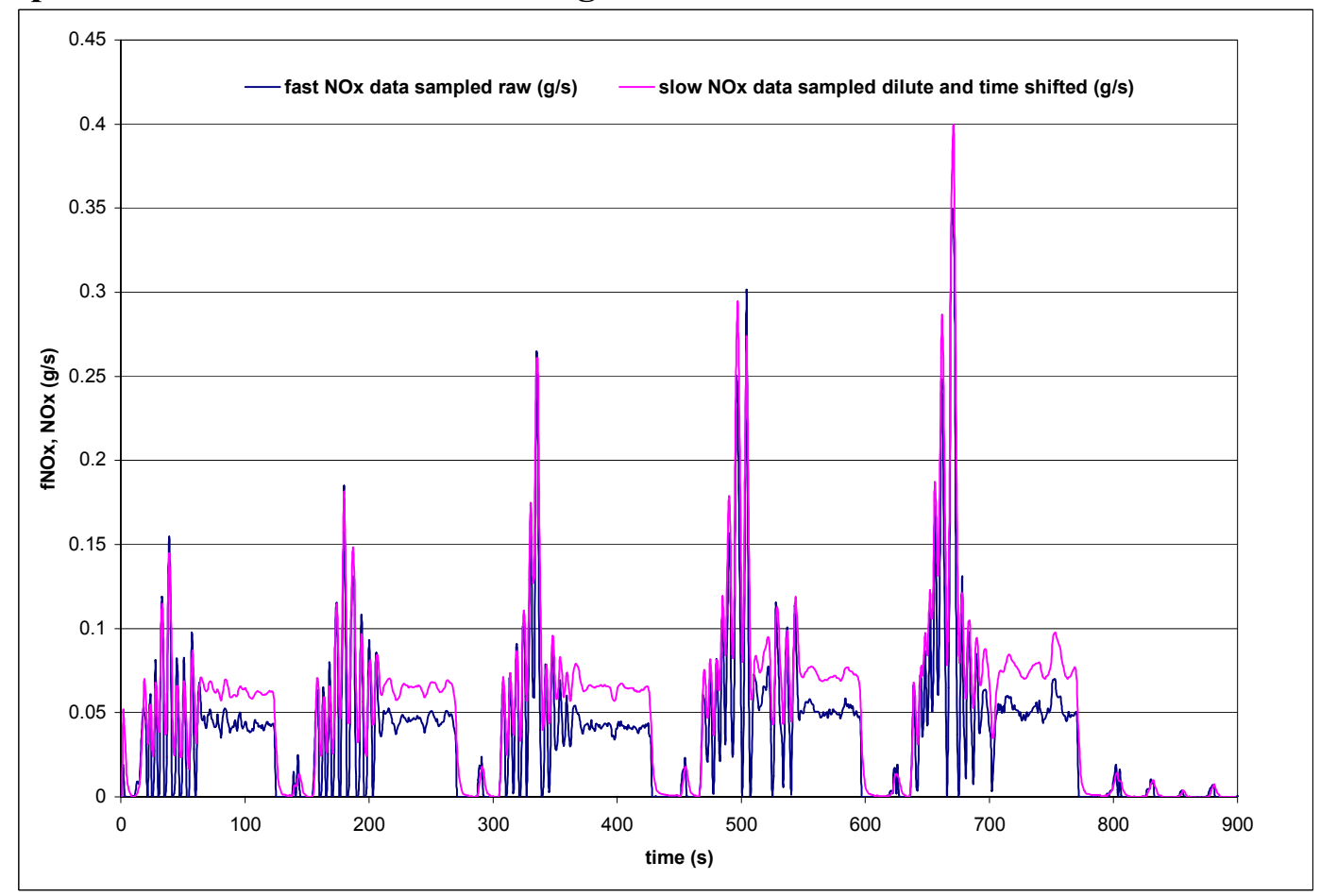

Figure 91 Variation of $\mathrm{NO}_{x}$ emissions with time for WVU 5- Peak cycle with time shifted slow $\mathrm{NO}_{\mathrm{x}}$ data. 


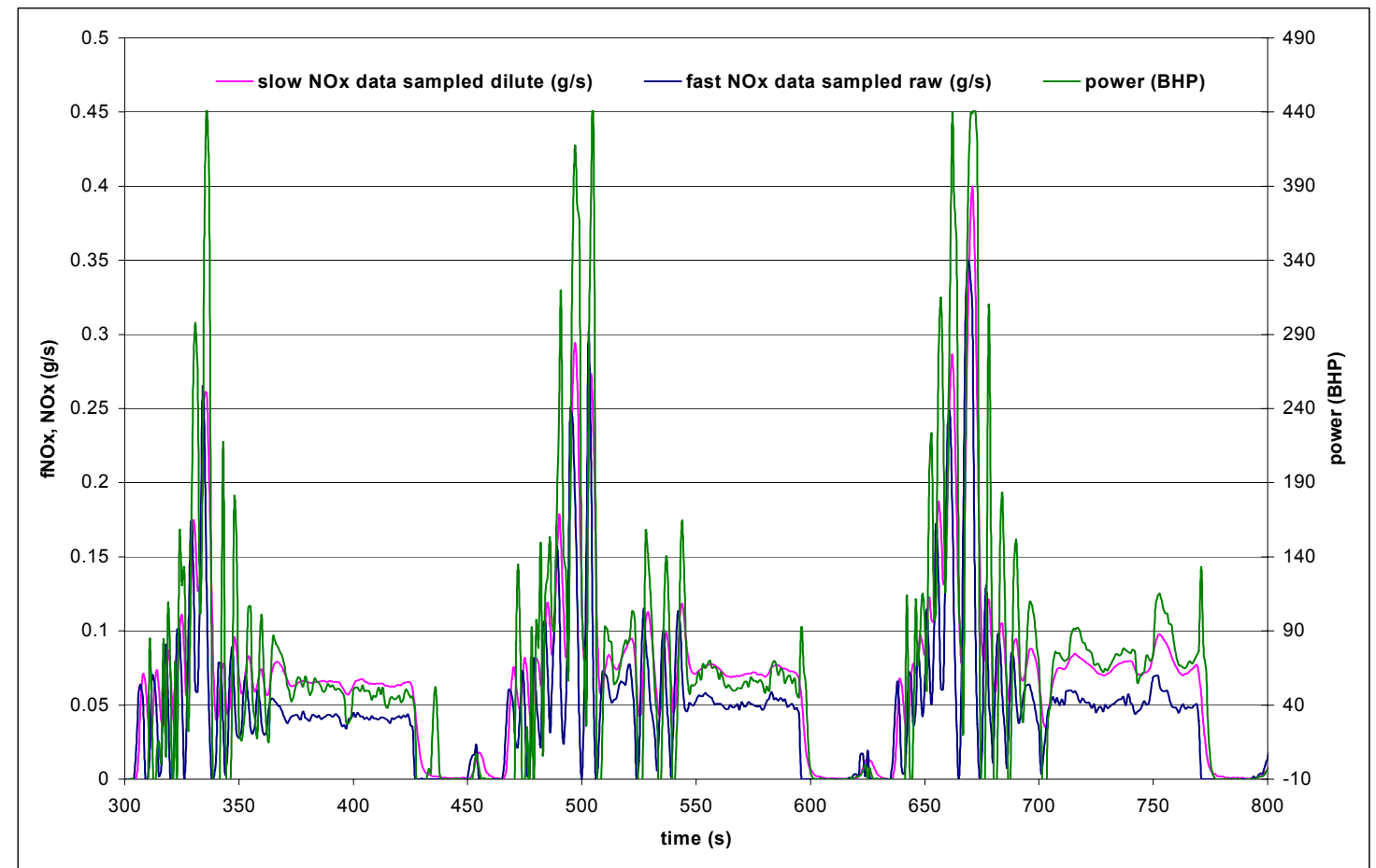

Figure 92 Power and $\mathrm{NO}_{\mathrm{x}}$ emissions variation with time for the WVU 5 - Peak cycle.

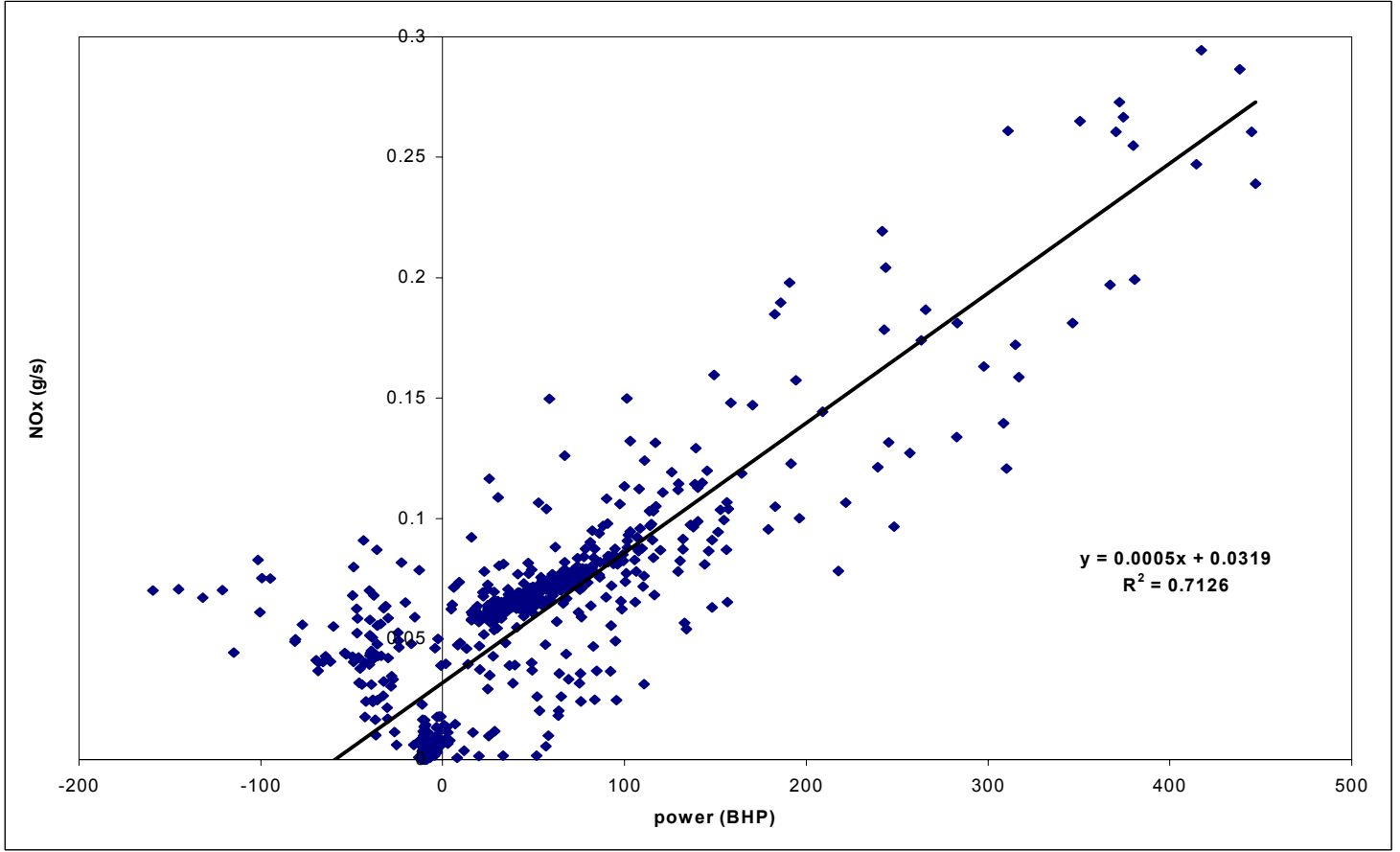

Figure 93 Relation between slow $\mathrm{NO}_{\mathrm{x}}$ and power for WVU 5 - Peak cycle. 


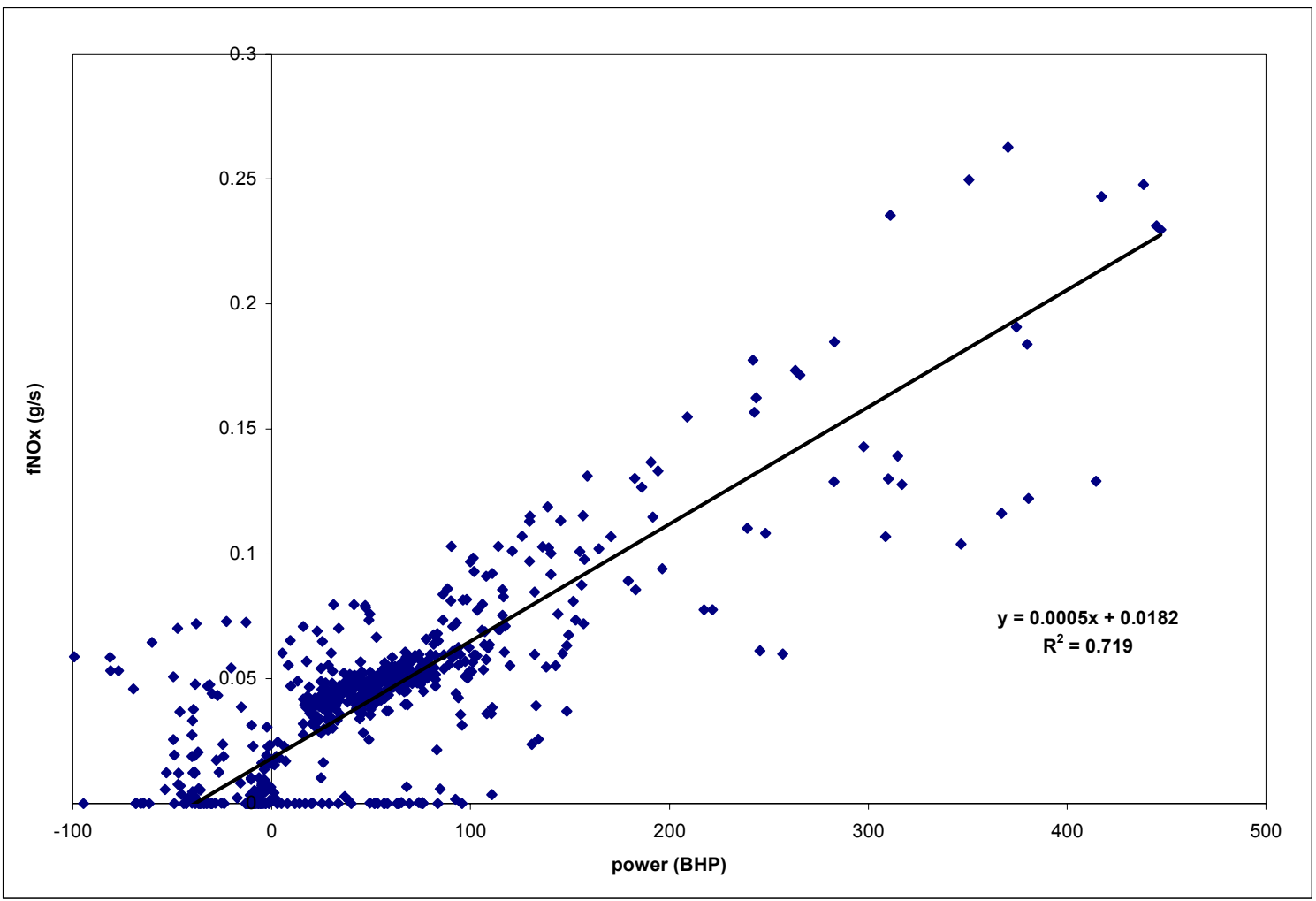

Figure 94 Relation fast $\mathrm{NO}_{\mathrm{x}}$ and power for WVU 5 - Peak cycle. 